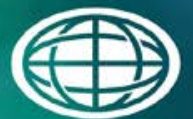

Savannah River

National Laboratory ${ }^{m}$

OPERATED BY SAVANNAH RIVER NUCLEAR SOLUTIONS

\title{
Corrosion Impact of Alternate Reductant on DWPF and Downstream Facilities
}

J. I. Mickalonis

K. J. Imrich

C. M. Jantzen

T. H. Murphy

J. E. Wilderman

December 2014

SRNL-STI-2014-00281, Revision 0 


\section{DISCLAIMER}

This work was prepared under an agreement with and funded by the U.S. Government. Neither the U.S. Government or its employees, nor any of its contractors, subcontractors or their employees, makes any express or implied:

1. warranty or assumes any legal liability for the accuracy, completeness, or for the use or results of such use of any information, product, or process disclosed; or

2. representation that such use or results of such use would not infringe privately owned rights; or

3. endorsement or recommendation of any specifically identified commercial product, process, or service.

Any views and opinions of authors expressed in this work do not necessarily state or reflect those of the United States Government, or its contractors, or subcontractors.

\section{Printed in the United States of America \\ Prepared for U.S. Department of Energy}


Keywords: Glycolic acid, DWPF, steels, high-nickel alloys, corrosion

Retention: Permanent

\title{
Corrosion Impact of Alternate Reductant on DWPF and Downstream Facilities
}

\author{
J. I. Mickalonis \\ K. J. Imrich \\ C. M. Jantzen \\ T. H. Murphy \\ J. E. Wilderman
}

December 2014 


\section{REVIEWS AND APPROVALS}

\section{AUTHORS:}

J. I. Mickalonis, SRNL/Materials Science \& Technology

K. J. Imrich, SRNL/Materials Science \& Technology

C. M. Jantzen, SRNL/E\&CPT Research Programs

M. H. Murphy, SRNL/Materials Science \& Technology

J. E. Wilderman, SRNL/Materials Science \& Technology

TECHNICAL REVIEW:

R. L. Sindelar, SRNL/Materials Science \&Technology

APPROVALS:

B. J. Wiersma, Manager

SRNL/Materials Science \& Technology

D. McGuire, Manager

SRNL/E\&CPT Research Programs

Date

E. J. Freed, Manager

SRR/DWPF/Saltstone Facility Engineering
Date

Date
Date

Date

Date 


\section{EXECUTIVE SUMMARY}

Glycolic acid is being evaluated as an alternate reductant in the preparation of high level waste for the Defense Waste Processing Facility (DWPF) at the Savannah River Site (SRS). During processing, the glycolic acid is not completely consumed and small quantities of the glycolate anion are carried forward to other high level waste (HLW) facilities. The impact of the glycolate anion on the corrosion of the materials of construction throughout the waste processing system has not been previously evaluated. A literature review had revealed that corrosion data in glycolate-bearing solution applicable to SRS systems were not available. Therefore, testing was recommended to evaluate the materials of construction of vessels, piping and components within DWPF and downstream facilities. The testing, conducted in nonradioactive simulants, consisted of both accelerated tests (electrochemical and hot-wall) with coupons in laboratory vessels and prototypical tests with coupons immersed in scale-up and mock-up test systems.

Eight waste or process streams were identified in which the glycolate anion might impact the performance of the materials of construction. These streams were 70\% glycolic acid (DWPF feed vessels and piping), SRAT/SME supernate (Chemical Processing Cell (CPC) vessels and piping), DWPF acidic recycle (DWPF condenser and recycle tanks and piping), basic concentrated recycle (HLW tanks, evaporators, and transfer lines), salt processing (ARP, MCU, and Saltstone tanks and piping), boric acid (MCU separators), and dilute waste (HLW evaporator condensate tanks and transfer line and ETF components). For each stream, high temperature limits and worst-case glycolate concentrations were identified for performing the recommended tests. Test solution chemistries were generally based on analytical results of actual waste samples taken from the various process facilities or of prototypical simulants produced in the laboratory.

The materials of construction for most vessels, components and piping were not impacted with the presence of glycolic acid or the impact is not expected to affect the service life. However, the presence of the glycolate anion was found to affect corrosion susceptibility of some materials of construction in the DWPF and downstream facilities, especially at elevated temperatures. The following table summarizes the results of the electrochemical and hot wall testing and indicates expected performance in service with the glycolate anion present.

\begin{tabular}{|c|c|c|c|l|}
\hline Process Stream & $\begin{array}{c}\text { [Glycolate] } \\
(\mathbf{g} / \mathbf{L})\end{array}$ & $\begin{array}{c}\text { Temperature } \\
\left({ }^{\circ} \mathbf{C}\right)\end{array}$ & Material & \multicolumn{1}{|c|}{ Material Performance } \\
\hline Glycolic Acid & 700 & 50 & 316L & $\begin{array}{l}\text { Acceptable - insignificant } \\
\text { corrosion expected for service }\end{array}$ \\
\hline & 50 & 304L & $\begin{array}{l}\text { Susceptible to localized corrosion - } \\
\text { additional testing and limits may } \\
\text { need to be established }\end{array}$ \\
\hline $\begin{array}{c}\text { SRAT/SME } \\
\text { Supernate }\end{array}$ & 63 & $95-100$ & C276 & $\begin{array}{l}\text { Susceptible to localized corrosion - } \\
\text { additional testing and limits may } \\
\text { need to be established }\end{array}$ \\
\hline & 50 & C276 & $\begin{array}{l}\text { Acceptable - insignificant } \\
\text { corrosion expected for service }\end{array}$ \\
\hline & $90-100$ & Ultimet ${ }^{\circledR}$ & $\begin{array}{l}\text { Susceptible to localized corrosion - } \\
\text { additional testing and limits may } \\
\text { need to be established }\end{array}$ \\
\hline & 100 & Stellite ${ }^{\circledR}$ & $\begin{array}{l}\text { Susceptible to localized corrosion - } \\
\text { additional testing and limits may } \\
\text { need to be established }\end{array}$ \\
\hline
\end{tabular}




\begin{tabular}{|c|c|c|c|c|}
\hline Process Stream & $\begin{array}{l}\text { [Glycolate] } \\
\text { (g/L) }\end{array}$ & $\begin{array}{l}\text { Temperature } \\
\left({ }^{\circ} \mathrm{C}\right)\end{array}$ & Material & Material Performance \\
\hline & & 50 & 304L & $\begin{array}{l}\text { Acceptable - insignificant } \\
\text { corrosion expected for service }\end{array}$ \\
\hline \multirow[t]{2}{*}{$\begin{array}{l}\text { SRAT/SME } \\
\text { Condensate } \\
\end{array}$} & 0.18 & 50 & $316 \mathrm{~L}$ & $\begin{array}{l}\text { Acceptable - insignificant } \\
\text { corrosion expected for service }\end{array}$ \\
\hline & 6 & 50 & $304 \mathrm{~L}$ & $\begin{array}{l}\text { Acceptable - insignificant } \\
\text { corrosion expected for service }\end{array}$ \\
\hline \multirow[t]{5}{*}{$\begin{array}{l}\text { DWPF Acidic } \\
\text { Recycle }\end{array}$} & 10 & 100 & AllCorr ${ }^{\circledR}$ & $\begin{array}{l}\text { Susceptible to localized corrosion, } \\
\text { especially at neutral pH, corrosion } \\
\text { at acid conditions acceptable }\end{array}$ \\
\hline & & 30 & AllCorr ${ }^{\circledR}$ & $\begin{array}{l}\text { Acceptable - insignificant } \\
\text { corrosion expected for service }\end{array}$ \\
\hline & & $100 / 50$ & C276 & $\begin{array}{l}\text { Acceptable - insignificant } \\
\text { corrosion expected for service }\end{array}$ \\
\hline & & 30 & $304 \mathrm{~L}$ & $\begin{array}{l}\text { Acceptable - insignificant } \\
\text { corrosion expected for service }\end{array}$ \\
\hline & & 50 & A285 & $\begin{array}{l}\text { Acceptable - insignificant } \\
\text { corrosion expected for service }\end{array}$ \\
\hline \multirow[t]{7}{*}{ Basic recycle } & 10 & 100 & G30 & $\begin{array}{l}\text { Susceptible to localized corrosion - } \\
\text { additional testing and limits may } \\
\text { need to be established }\end{array}$ \\
\hline & & 40 & & $\begin{array}{l}\text { Acceptable - insignificant } \\
\text { corrosion expected for service }\end{array}$ \\
\hline & & $100 / 30$ & $316 \mathrm{~L}$ & $\begin{array}{l}\text { Acceptable - insignificant } \\
\text { corrosion expected for service }\end{array}$ \\
\hline & & $100 / 30$ & 304L & $\begin{array}{l}\text { Acceptable - insignificant } \\
\text { corrosion expected for service }\end{array}$ \\
\hline & & 30 & $304 \mathrm{~L}$ & $\begin{array}{l}\text { Acceptable - insignificant } \\
\text { corrosion expected for service }\end{array}$ \\
\hline & & 100 & A537 & $\begin{array}{l}\text { Pitting corrosion, temperature fell } \\
\text { outside that specified in the } \\
\text { corrosion control program for HLW }\end{array}$ \\
\hline & & 30 & A537 & $\begin{array}{l}\text { Acceptable - insignificant } \\
\text { corrosion expected for service }\end{array}$ \\
\hline \multirow[t]{4}{*}{ Salt Processing } & 10 & 50 & Astralloy ${ }^{\circledR}$ & $\begin{array}{l}\text { Acceptable - insignificant } \\
\text { corrosion expected for service }\end{array}$ \\
\hline & & & $316 \mathrm{~L}$ & $\begin{array}{l}\text { Acceptable }- \text { insignificant } \\
\text { corrosion expected for service }\end{array}$ \\
\hline & & & $304 \mathrm{~L}$ & $\begin{array}{l}\text { Acceptable - insignificant } \\
\text { corrosion expected for service }\end{array}$ \\
\hline & & & A537 & $\begin{array}{l}\text { Acceptable - insignificant } \\
\text { corrosion expected for service }\end{array}$ \\
\hline Boric Acid & 10 & 50 & $316 \mathrm{~L}$ & $\begin{array}{l}\text { Acceptable - insignificant } \\
\text { corrosion expected for service }\end{array}$ \\
\hline \multirow[t]{2}{*}{ Dilute waste } & 0.033 & 107 & G3 & $\begin{array}{l}\text { Susceptible to localized corrosion - } \\
\text { additional testing and limits may } \\
\text { need to be established }\end{array}$ \\
\hline & & 95 & $304 \mathrm{~L}$ & $\begin{array}{l}\text { Acceptable - insignificant } \\
\text { corrosion expected for service }\end{array}$ \\
\hline
\end{tabular}




\begin{tabular}{|c|c|c|c|l|}
\hline Process Stream & $\begin{array}{c}\text { [Glycolate] } \\
(\mathbf{g} / \mathbf{L})\end{array}$ & $\begin{array}{c}\text { Temperature } \\
\left({ }^{\circ} \mathbf{C}\right)\end{array}$ & Material & \multicolumn{1}{|c|}{ Material Performance } \\
\hline & & 30 & $304 \mathrm{~L}$ & $\begin{array}{l}\text { Acceptable }- \text { insignificant } \\
\text { corrosion expected for service }\end{array}$ \\
\hline & 95 & A537 & $\begin{array}{l}\text { Pitting corrosion, nitrite } \\
\text { concentration fell outside that } \\
\text { specified in the corrosion control } \\
\text { program for HLW }\end{array}$ \\
\hline & & 30 & A537 & $\begin{array}{l}\text { Pitting corrosion, nitrite } \\
\text { concentration fell outside that } \\
\text { specified in the corrosion control } \\
\text { program for HLW }\end{array}$ \\
\hline Molten glass & & & $\begin{array}{c}\text { Inconel }{ }^{\circledR} \\
690\end{array}$ & $\begin{array}{l}\text { Acceptable - insignificant } \\
\text { corrosion expected for service }\end{array}$ \\
\hline & & & $\begin{array}{c}\text { Monofrax } \\
\text { K-3 }\end{array}$ & Increased corrosion rate \\
\hline
\end{tabular}

The coupons exposed during the Cold Cap Evaluation Furnace (CEF) testing included an Inconel ${ }^{\circledR} 690$ (I690) argon purge bubbler and a Monofax ${ }^{\mathrm{TM}} \mathrm{K}-3$ refractory block (K-3), which was attached to the bubbler. The CEF testing was conducted at $1050{ }^{\circ} \mathrm{C}$ for 25 days with feed containing $\mathrm{Cl}^{-}$and $\mathrm{SO}_{4}^{-2}$ at concentrations of 300 and 1200 ppm, respectively.

The total degradation (material loss and internal attack) of the bubbler was measured for regions of the bubbler from the melt pool, melt line, and vapor space. Results showed that only minimal degradation was observed in all three regions. Degradation rates in the melt pool, melt line, and vapor space regions were $0.035,0.015$, and $0.026 \mathrm{in} / \mathrm{yr}$, respectively. These results indicated the glycolic acid feed is not particularly aggressive to I690 at elevated temperatures.

Cracks observed on the interior of the as-received pipe and the CEF bubbler originated from the fabrication process. Although the surface defects were shallow, they reduce the effective wall thickness and can act as stress concentrators. The presence of these cracks did not affect the results of this test but their presence in actual DWPF melter bubblers could limit their service lives.

The general corrosion mechanism of K-3 refractory in the glycolic acid flowsheet is the same as the mechanism in the formic acid flowsheet except for the following:

1. Extensive cracking and cavitation has not been observed in the formic acid flowsheet since bubbled melter or crucible studies have not been performed on the formic acid flowsheet with a K-3 coupon.

2. Selective $\mathrm{Fe}^{\circ}$ depletion to a depth that exceeds any corrosion rates previously measured in formic acid flowsheets even with fairly oxidized formic acid feeds since no bubbled melter or crucible studies have been performed on the formic acid flowsheet with a K-3 coupon.

3. The $\mathrm{Fe}^{\circ}$ depletion appears to create the "cracks" and "voids" which appear to be a selective attack of the $\mathrm{Fe}^{\circ}$ used in the refractory processing and attack of the $\mathrm{Fe}^{\circ}$ component of the $\mathrm{Fe}^{\circ}-\mathrm{Cr}^{\circ}$ solid solution that forms along grain boundaries in the refractory during processing.

4. General corrosion exceeds that in oxidized feeds, i.e. the "average loss of material" is much greater than the selective penetration depth of glass into the refractory. This does not include the $\mathrm{Fe}^{\circ}$ depletion zone. A general corrosion rate is difficult to measure due to the cracking and cavitation. In regions without the cracking and cavitation it appears that the K-3 corrosion is within the DWPF 
design basis, but in the regions with cracking and cavitation the K-3 corrosion rate is at or greater than the DWPF design basis.

5. The cavitation is likely due to the proximity of the refractory coupon to the bubbler orifice but the cracking is related to the $\mathrm{Fe}^{\circ}$ depletion caused by excessive nitric acid used in the glycolic acid CEF campaign.

The expected performance of the materials of construction within the CPC, specifically C276, Ultimet ${ }^{\circledR}$ and Stellite ${ }^{\circledR}$ at boiling temperatures, is questionable due to the susceptibility to localized corrosion identified during this testing. Since the glycolate anion concentration is at the highest in the CPC for the whole HLW processing system, determining operating limits where localized corrosion is not a concern is stressed. Additional testing for these materials is recommended to better understand the limits of these results and identify conditions for acceptable performance in service.

These proposed tests would include performing electrochemical testing with formic acid based SRAT/SME supernates, which would provide a correlation between accelerated electrochemical test results and observed performance of components within the CPC and with glycolic acid based SRAT/SME supernates at levels of aggressive species (chloride, sulfate and mercury) where localized corrosion does not occur. Similar simulants would be used in hot-wall tests to verify that localized corrosion also does not occur under heat transfer conditions. Finally, a coupon immersion test is recommended to verify that the accelerated results of the electrochemical test occur with time during an extended exposure in the coupon test.

Additional testing was also recommended for other materials where the presence of the glycolate anion impacted test results. These tests were recommended to better identify the temperature and glycolic acid limits for acceptable performance of the materials of construction, especially those susceptible to localized corrosion.

1. Coupon immersion test with 304L in 70\% glycolic acid at actual service temperature to determine if pitting occurs.

2. Hot-wall testing for G30 and G3 in waste stream simulants without glycolic acid present for comparison to results with glycolate anion present, where pitting and crevice corrosion was observed.

3. Metallurgical examination of the inner diameter of I690 pipe used in fabrication of melter bubbler to determine presence of cracks, which would reduce effective thickness and act as stress concentrators.

4. Perform modified ASTM C621 tests in glycolic acid feeds to determine impact of glycolic acid vs. formic acid with and without the impact of Ar bubbling, i.e. all the formic acid flowsheet corrosion data has been derived in non-bubbled pilot scale melters except for the CEF glycolic acid campaign. This testing should suffice to get more precise comparative corrosion data for the K-3. 


\section{TABLE OF CONTENTS}

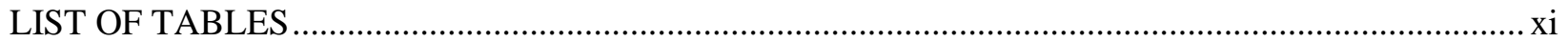

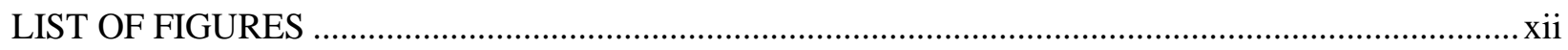

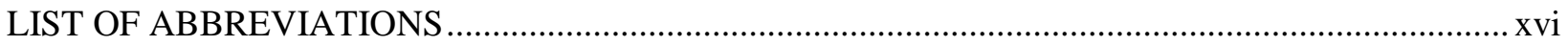

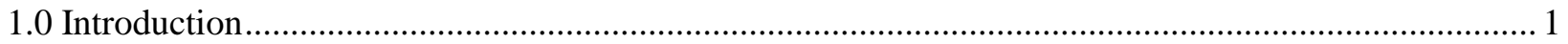

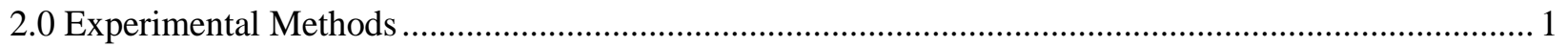

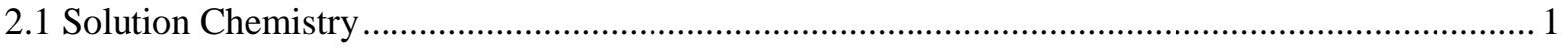

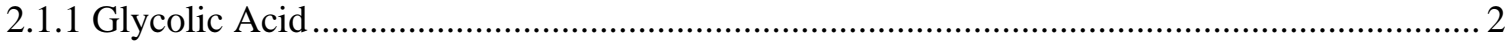

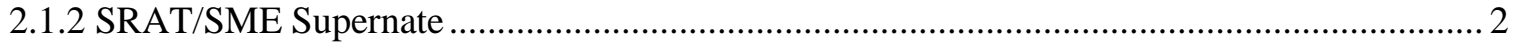

2.1.3 SRAT/SME Condensate ................................................................................................. 2

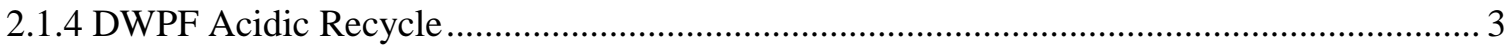

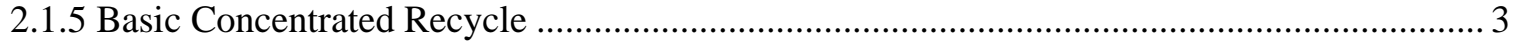

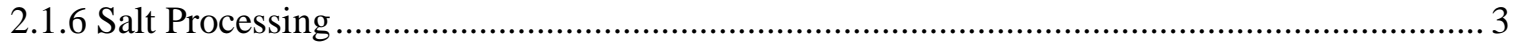

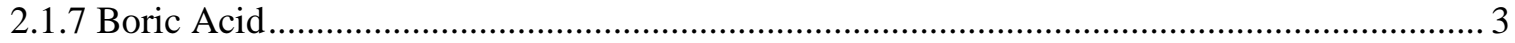

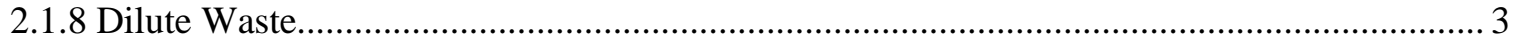

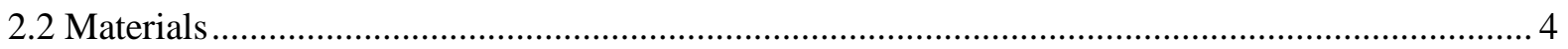

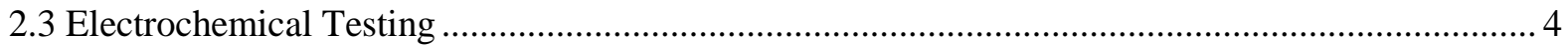

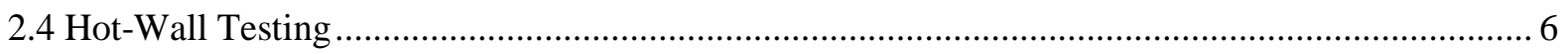

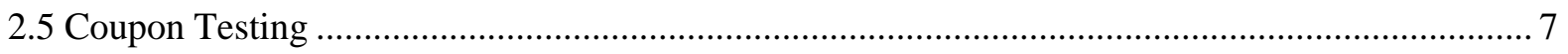

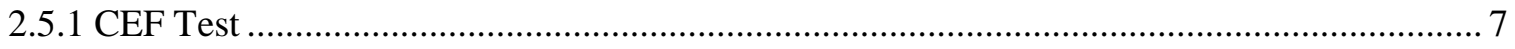

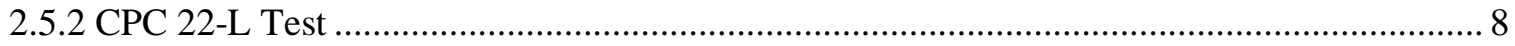

3.0 Results and Discussion - Non-Melter Materials of Construction ..................................................... 8

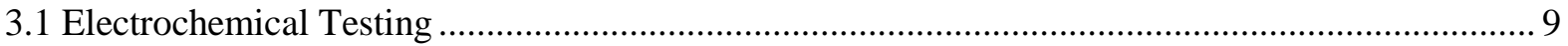

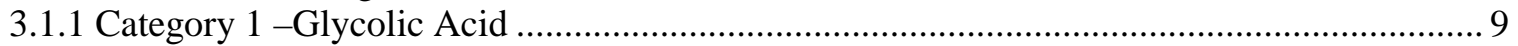

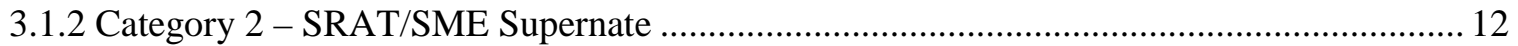

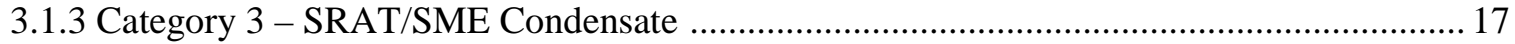

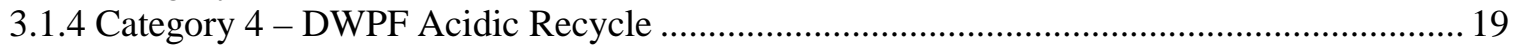

3.1.5 Category 5 - Basic Recycle ................................................................................................. 23

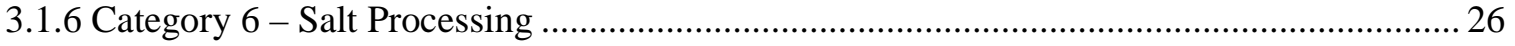

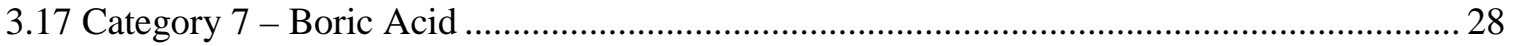

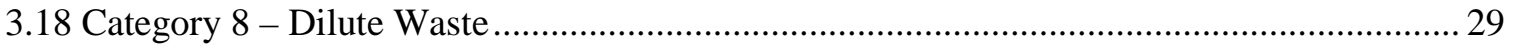

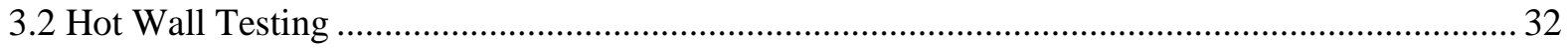

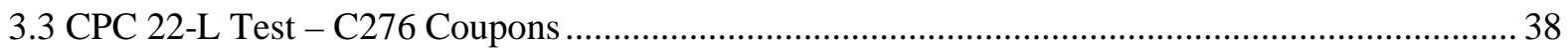

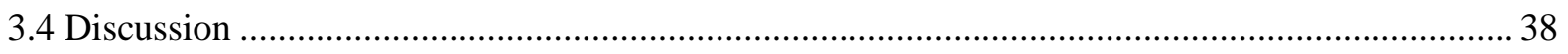

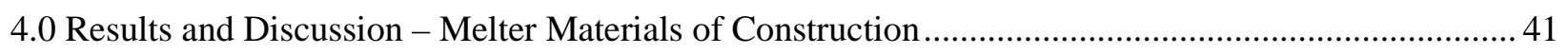

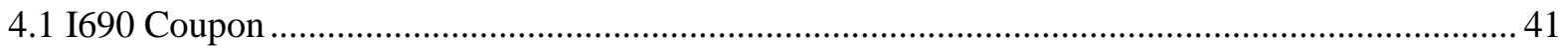

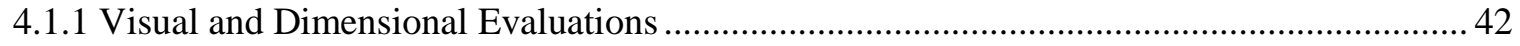

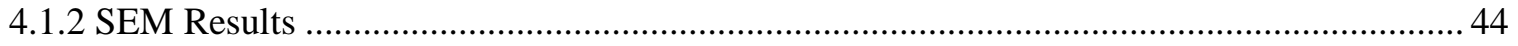

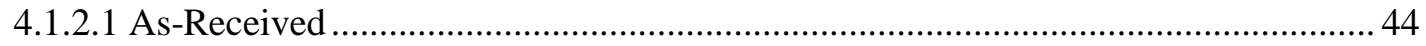

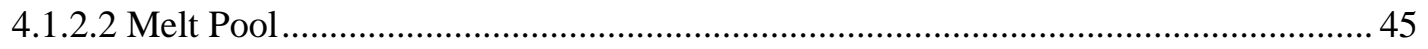

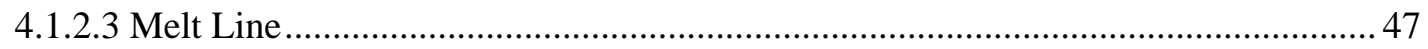

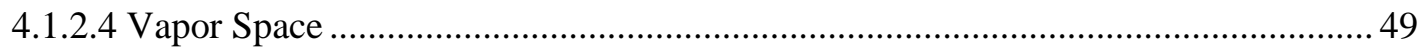

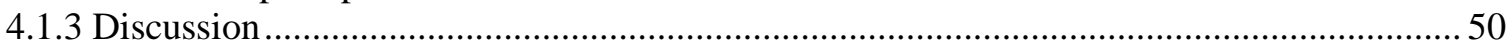

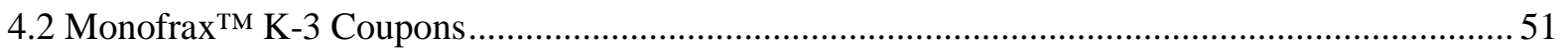


4.2.1 Corrosion Mechanisms and Rates in Formic Acid Melter Feeds 51

4.2.2 Corrosion Mechanisms and Rates in Glycolic Acid Melter Feeds

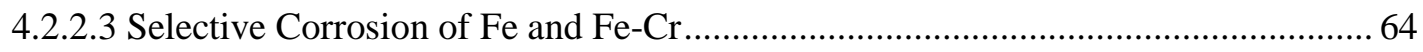

5.0 Recommendations

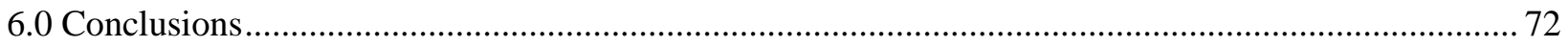

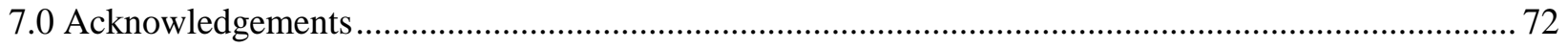

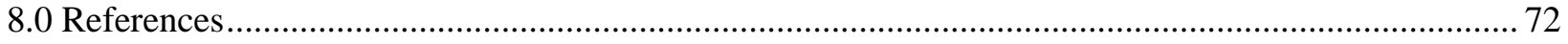

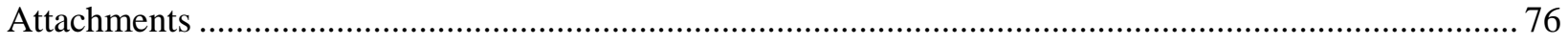

Attachment 1 - Vessels and Components in the DWPF and Downstream Facilities in Contact with Glycolate or Glycolic Acid........................................................................................ 76

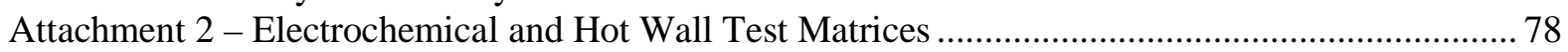

Attachment 3 -Solution Chemistries for Electrochemical and Hot Wall Testing............................... 81 


\section{LIST OF TABLES}

Table 2-1 Solution Categories Used for Electrochemical and Hot Wall Testing................................ 2

Table 2-2 Material Compositions for Electrochemical Test Samples ............................................. 4

Table 2-3 Material Values for Determining Corrosion Rate...........................................................5

Table 3-1 Solution Categories Used for Electrochemical and Hot Wall Testing .............................9

Table 3-2 Electrochemical Parameters for 316L and 304L in Category 1 Solutions..........................9

Table 3-3 Electrochemical Parameters for C276 in Category 2 Solutions....................................... 13

Table 3-4 Electrochemical Parameters for Ultimet, Stellite, and 304L in Category 2 Solutions ...... 16

Table 3-5 Electrochemical Parameters for 316L and 304L in Category 3 Solutions ...................... 18

Table 3-6 Electrochemical Parameters for AllCorr, C276, 304L and A285 in Category 4 Solutions

Table 3-7 Electrochemical Parameters for G30, 316L, 304L and A537 in Category 5 Solutions ... 23

Table 3-8 Electrochemical Parameters for 316L, 304L, A537, and Astralloy in Category 6 Solutions

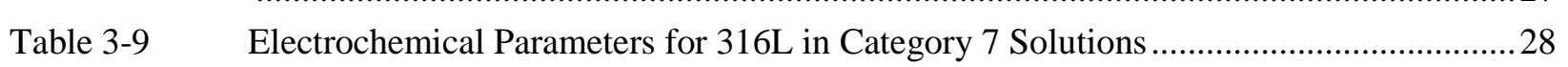

Table 3-10 Electrochemical Parameters for G3, 304L, and A537 in Category 8 Solutions ................30

Table 3-11 Hot-Wall Test Result for C276, Ultimet, G30 and G3 ................................................32

Table 4-1 Monofrax ${ }^{\mathrm{TM}}$ K-3 Corrosion Depths Measured in Non-Bubbled SRNL Melters and by ASTM C621 Modified and Non-Modified Crucible Measurements ..............................56

Table 4-2 Feed Compositions Used in Monofrax ${ }^{\mathrm{TM}}$ K-3 Crucible and Mini-melter Tests ...............57

Table 4-3 Relative Corrosion Rates of Pilot Scale Melters, Crucible Studies, and DWPF Design

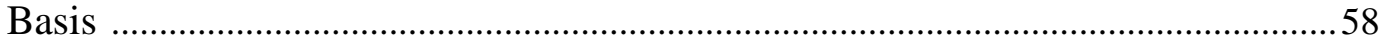

Table 4-4 General Corrosion Rate for Monofrax ${ }^{\mathrm{TM}}$ K-3 Refractory in Glycolic Acid ...................62

Table 4-5 Reduction/Oxidation Half Reactions ............................................................................. 69 


\section{LIST OF FIGURES}

Figure 2-1 Polarization results from a ASTM G5 standardized test performed with potentiostat SN 85108 that was used during the alternate reductant testing

Figure 2-2 Hot-wall test apparatus for corrosion testing under heat transfer conditions .................... 7

Figure 2-3 Coupon rack used for scale demonstration testing of the CPC in the 22L vessel: (A) top view and (B) side view ............................................................................................... 8

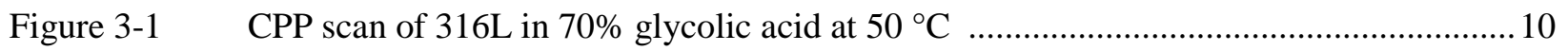

Figure 3-2 OCP versus time scans of $304 \mathrm{~L}$ in $70 \%$ glycolic acid at $50{ }^{\circ} \mathrm{C}$..................................... 10

Figure 3-3 CPP scan of 304L in $70 \%$ glycolic acid at $50{ }^{\circ} \mathrm{C}$ with two different starting OCPs ....... 11

Figure 3-4 Stereomicroscope images for 304L samples taken after electrochemical testing in $70 \%$ glycolic acid at $50{ }^{\circ} \mathrm{C}$ : (A) 304L1A-2; and (B) 304L2A ............................................... 11

Figure 3-5 OCP monitoring of C276 in SRAT/SME supernate with sodium glycolate and high levels

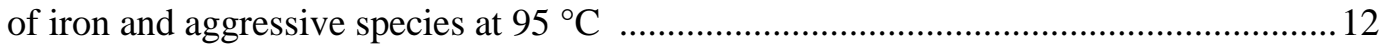

Figure 3-6 CPP scans of C276 in SRAT/SME supernate without sodium glycolate and with high levels of iron and aggressive species at $99{ }^{\circ} \mathrm{C} \mathrm{\ldots ...........................................................} 13$

Figure 3-7 Post-test photographs of C276 in Category 2 solutions: (A) with sodium glycolate and low level of aggressive species (condition a); and (B) without sodium glycolate and low levels of iron and high levels of aggressive species (condition b) ..................................... 14

Figure 3-8 CPP scans for C276 in SRAT/SME supernate with (A) and without (B) sodium glycolate as a function of the concentrations of iron and aggressive species ................................... 15

Figure 3-9 CPP scans for Ultimet (A) and Stellite (B) in SRAT/SME supernate with sodium glycolate as a function of the concentrations of iron and aggressive species ................... 17

Figure 3-10 CPP scans for 316L (A) and 304L (B) in SRAT/SME condensate with (green and blue curves) and without (red and black curves) sodium glycolate at $50{ }^{\circ} \mathrm{C}$.............................. 18

Figure 3-11 CPP scans for AllCorr in the DWPF recycle solution at $\mathrm{pH} 8.1$ with $10 \mathrm{~g} / \mathrm{L}$ sodium

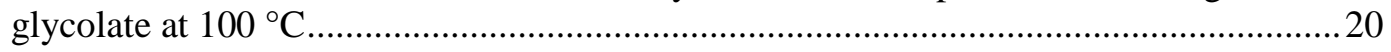

Figure 3-12 Surface analysis results of AllCorr sample 25Ac100A, which was tested in the DWPF recycle solution at $\mathrm{pH} 8.1$ with $10 \mathrm{~g} / \mathrm{L}$ sodium glycolate at $100^{\circ} \mathrm{C}$ : (A) $10 \mathrm{X}$ photograph; (B) height scan at 50x; and (C) EDS spectra showing presence of Hg........................... 21

Figure 3-13 CPP scans for C276 in the $\mathrm{pH} 1.5$ DWPF recycle solution with (10 g/L, cp22C100A) and without (CP29C100B) the glycolate anion, the $\mathrm{pH} 8$ solution with glycolate $(10 \mathrm{~g} / \mathrm{L}$, cp24C100A) at $100{ }^{\circ} \mathrm{C}$, and the $\mathrm{pH} 12.4$ solution at $50{ }^{\circ} \mathrm{C}$ with glycolate $(10 \mathrm{~g} / \mathrm{L}$, ср26C50A).

Figure 3-14 CPP scans for 304L in the pH 1.5 DWPF recycle solution with $(10 \mathrm{~g} / \mathrm{L}$, cp164L30bm) and without (cp284L30B) the glycolate anion and the $\mathrm{pH} 8$ solution with glycolate (10 $\mathrm{g} / \mathrm{L}, \mathrm{cp} 204 \mathrm{~L} 30 \mathrm{~B})$ at $30^{\circ} \mathrm{C}$

Figure 3-15 Photographs of two 304L samples tested in the $\mathrm{pH} 7.7$ DWPF recycle solution with 10 g/L sodium glycolate at $30^{\circ} \mathrm{C}$ : (A) 204L30A and (B) 204L30B .................................. 23

Figure 3-16 CPP scans for G30 in the basic recycle solutions with (10 g/L, cp38G30100A) and without (cp41G30blgam) the glycolate anion at $100{ }^{\circ} \mathrm{C}$ and at $30{ }^{\circ} \mathrm{C}$ with glycolate $(10$ $\mathrm{g} / \mathrm{L}, \mathrm{cp} 34 \mathrm{G} 3030 \mathrm{~B})$................................................................................................ 24

Figure 3-17 CPP scans for 316L in the basic recycle solutions with $10 \mathrm{~g} / \mathrm{L}$ sodium glycolate at $30{ }^{\circ} \mathrm{C}$

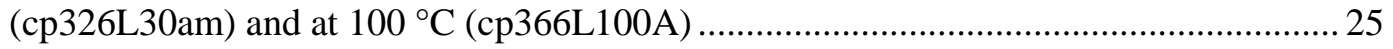


Figure 3-18 CPP scans for 304L in the basic recycle solutions with (10 g/L, cp354L100B) and without (cp394L100B) the glycolate anion at $100{ }^{\circ} \mathrm{C}$ and at $30^{\circ} \mathrm{C}$ with glycolate $(10 \mathrm{~g} / \mathrm{L}$, cp314L30bm) ....................................................................................................... 25

Figure 3-19 CPP scans for A537 in the basic recycle solutions with (10 g/L, cp37A5100A) and without (cp40A5100bm) the glycolate anion at $100{ }^{\circ} \mathrm{C}$ and at $30^{\circ} \mathrm{C}$ with glycolate $(10$ $\mathrm{g} / \mathrm{L}, \mathrm{cp} 33 \mathrm{~A} 530 \mathrm{~B})$

Figure 3-20 CPP scans for 304L (cp444L50A) and 316L (cp436L50B) in the salt processing solutions with $10 \mathrm{~g} / \mathrm{L}$ sodium glycolate at $50{ }^{\circ} \mathrm{C}$ 27

Figure 3-21 CPP scans for A537 (cp42A550B) and Astralloy (cp45Ay50A) in the salt processing solutions with $10 \mathrm{~g} / \mathrm{L}$ sodium glycolate and Astralloy (cp48Ay50A) with no glycolate anion at $50{ }^{\circ} \mathrm{C}$ 28

Figure 3-22 CPP scans for 316L in $10 \mathrm{mM}$ boric acid with (cp496L50A) and without (cp506L50B) 10 $\mathrm{g} / \mathrm{L}$ sodium glycolate at $50{ }^{\circ} \mathrm{C}$ 29

Figure 3-23 CPP scans for G3 in a dilute waste chemistry with (cp66G3107A) and without (cp67G3107A) $0.033 \mathrm{~g} / \mathrm{L}$ sodium glycolate at $107^{\circ} \mathrm{C}$ 30

Figure 3-24

Figure 3-25 CPP scans for 304L in a dilute waste chemistry with (cp604L95A) and without (cp694L95A) $0.033 \mathrm{~g} / \mathrm{L}$ sodium glycolate at a pH 3and $107^{\circ} \mathrm{C}$ 31 CPP scans for 304L in a dilute, pH 12 waste chemistry with (cp634L95B) and without (cp714L95A) $0.033 \mathrm{~g} / \mathrm{L}$ sodium glycolate at $95{ }^{\circ} \mathrm{C}$ and with (cp574L30B) $0.033 \mathrm{~g} / \mathrm{L}$ sodium glycolate at $30{ }^{\circ} \mathrm{C}$

Figure 3-26 CPP scans for A537 in a dilute, $\mathrm{pH} 12$ waste chemistry with (cp65A595A) and without (cp70A595A) $0.033 \mathrm{~g} / \mathrm{L}$ sodium glycolate at $95{ }^{\circ} \mathrm{C}$ and with (cp59A530A and B) 0.033 $\mathrm{g} / \mathrm{L}$ sodium glycolate at $30{ }^{\circ} \mathrm{C}$ .32

Figure 3-27 C276 hot-wall sample after 22 days exposed to the SRAT/SME supernate chemistry with low iron and high aggressive species concentrations: (A) 35-mm photograph before cleaning; (B) 35-mm photograph after cleaning; (C) LCM laser image of surface under gasket; (D) LCM laser image of surface at sample center; (E); LCM height scan showing pit depths under gasket and (F) LCM height scan showing pit depths at sample center . 34

Figure 3-28 Ultimet hot-wall sample after 34 days exposed to the SRAT/SME supernate chemistry with low iron and high aggressive species concentrations: (A) 35-mm photograph before cleaning; (B) 35-mm photograph after cleaning; (C) LCM laser image of surface under gasket; (D) LCM laser image of surface at sample center; (E); LCM height scan showing pit depths under gasket and (F) LCM height scan showing pit depths at sample center .. 35

Figure 3-29 G3 hot-wall sample after 27 days exposed to a dilute waste chemistry: (A) 35-mm photograph before cleaning; (B) 35-mm photograph after cleaning; (C) LCM laser image of surface at sample center; (D) LCM laser image of surface near gasket; (E); LCM height scan showing pit depths under gasket. 36

Figure 3-30 G30 hot-wall sample after 22 days exposed to a basic recycle waste chemistry: (A) 35mm photograph before cleaning; (B) 35-mm photograph after cleaning; (C) LCM laser image of deposit at sample center; (D) LCM height image of deposit at sample center; and (E); LCM height line scan showing pit depths with the deposit ............................. 37

Figure 3-31 Photographs (35-mm) of C276 coupon \#2 after exposure during the 22-L CPC testing (A) front before cleaning; (B) front after cleaning; (C) back before cleaning; and (D) back

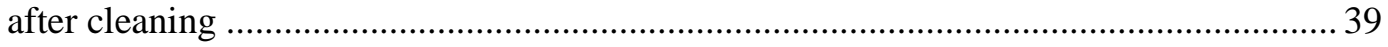

Figure 4-1 Glass-coated I690 bubbler in post-test condition showing location of refractory K-3 coupon 
Figure 4-2 Glass-coated I690 bubbler in post-test condition: (A) glass-coated K-3 refractory coupon in I690 holder and (B) flange and bubbler tube in the vapor space region ....................... 41

Figure 4-3 CEF temperature profile and argon flow rate during the 25 day CEF glycolic acid flowsheet campaign ............................................................................................... 43

Figure 4-4 Photographs showing final sectioning of the 690 bubbler for the samples taken from the melt pool, melt line and vapor space regions ................................................................. 43

Figure 4-5 SEM images of the inner diameter surface of an as-received, unexposed section of I690 pipe where shallow cracks, approximately 2 mils deep, are visible below the deformed metal which appears to be a lap ....................................................................................... 44

Figure 4-6 Secondary electron image of the outer diameter surface of an as-received, unexposed section of I690 pipe, where no cracking visible on surface ............................................. 44

Figure 4-7 Secondary electron images of the outer (A) and inner (B) diameter surfaces of the melt pool regions (White bars indicate the average depth of internal attack) ......................... 45

Figure 4-8 Crack on inner surface of the melt pool sample: (A) Secondary electron image and (B) EDS spectrum showing chromium oxide inside the crack .......................................... 45

Figure 4-9 Secondary electron and dot map images for various elements from the melt pool outer surface. Note the diffusion of sulfur and oxygen into the metal lattice ......................... 46

Figure 4-10 Secondary electron and dot map images for various elements from the melt pool inner diameter surface. Note the diffusion oxygen into the cracks and metal lattice. Sulfur is just present on the surface. Only a small amount of oxygen had diffused into the metal matrix 47

Figure 4-11 Secondary electron (A) and backscattered images (B) of the outer diameter from the melt line region. Rods visible along the metal surface shown in the BS image contain sulfur 48

Figure 4-12 SEM secondary electron image showing cracks on the melt line inner diameter surface 48

Figure 4-13 Secondary electron and dot map images for various elements from the melt line outer surface. Chromium oxide is evident at the metal/glass interface. Sulfur is also present in the glass but small regions are found in the metal matrix (see arrow). Chromium depletion is evident as shown by slightly darker region at the near-surface region.......... 49

Figure 4-14 Backscattered images of the outer (A) and inner (B) diameter from the vapor region .... 50

Figure 4-15 Cracks on outer surface from the vapor space region: (A) Secondary electron image and (B) EDS spectrum showing chromium oxide inside the crack (trace amounts of $\mathrm{Cl}$ and $\mathrm{S}$ were also observed) 50

Figure 4-16 Secondary electron image of crack on inner diameter surface from the vapor space region and EDS spectra showing chromium oxide (spot 5) and a trace amount of sulfur inside the crack (spot 6) 51

Figure 4-17 K-3 corrosion layer resulting from molten glass: different morphologies of the corrosion layer (regions \#3 and \#4) separated from the penetration layer (regions \#2) and the bulk K-3 (region \#1). The bulk glass is indicated by region \#5. (Note the inclusion (region \#6) that has broken off from the corrosion layer and is dissolving in the glass in Figure 3-48) ............................................................53

Figure 4-18 An enlarged SEM image of the outer corrosion layer (region \#6 of Figure 3-47) of the K-3 refractory showing the breaking away of the Fe-Cr-Mn-Ni rich corrosion layer, which is an insoluble $\mathrm{NiMn}(\mathrm{Fe}, \mathrm{Cr})_{2} \mathrm{O}_{4}$ rich spinel and may be adherent to the melter refractory wall or spall off and fall to the bottom of the melter creating bottom deposits .54

Figure 4-19 Hot wall side (A) of K-3 refractory brick versus the as cut side (B) of the refractory brick 59 
Figure 4-20 K-3 refractory in the I690 cage after removal from the CEF melter (Note the region that was sectioned for SEM analyses to maintain the glass-refractory contact zone)...............6 60

Figure 4-21 Mechanism by which cavitation bubbles implode close to a fixed surface 60

Figure 4-22 Open porosity of the K-3 refractory, as received, at different magnifications: (A) 50x; (B) 500x; (C) 500x; and (D) 500x (Note that in picture (D) the bright "spots" are $\mathrm{Fe}^{\circ}$ which is used in refractory processing.). 61

Figure 4-23 (A) SEM of the K-3 refractory corrosion coupon immersed in glass made from glycolic acid feed from frit 418 for 25 days at $\sim 1150^{\circ} \mathrm{C}$; (B) SEM of the K-3 refractory corrosion coupon immersed in glass composed of DWPF black frit glass 165 for 5 days at $1150^{\circ} \mathrm{C}$ (Note the thick corrosion layer which is composed of two layers separated by a row of circular bubble-like precipitates. The outer layer is more porous and is designated the corrosion or "average loss" layer. The inner layer is termed the penetration layer) 62

Figure 4-24 X-ray maps showing enrichment (brighter outer rim image) in $\mathrm{Cr}$ in the corrosion layer corresponding to Figure 3-53 and showing depletion (darker outer rim image) in $\mathrm{Al}$ in the corrosion layer

Figure 4-25 X-ray maps showing enrichment (brighter outer rim image) in Fe in the corrosion layer corresponding to Figure 3-53 and showing depletion (darker outer rim image) in $\mathrm{Mg}$ in the corrosion layer

Figure 4-26 X-ray maps showing enrichment (brighter outer rim image) in $\mathrm{Ni}$ in the corrosion layer corresponding to Figure 3-53 and showing depletion (darker outer rim image) in Si in the corrosion layer

Figure 4-27 Hot-face of the K-3 refractory block that was in contact with the glass: (A) 100x and (B) 500x

Figure 4-28 Cracks, voids and cavitations in the K-3 refractory (Note how deeply the cracks and cavitation penetrate into the refractory): (A) 100x and (B) 40x 66

Figure 4-29 Cracks and filled voids along the cracks that are deep below the corrosion front in back scattered electron (A) image and secondary electron (B) image, where the secondary electron image shows that the voids are filled with a secondary phase 66

Figure 4-30 Results of EDS analyses of the different phases in Figure 3-59: (A) upper void; (B) lower

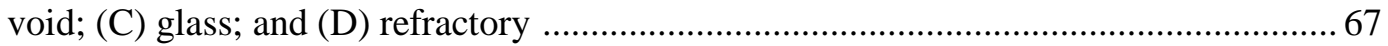

Figure 4-31 Phase morphology and composition of K-3 refractory (Note fluid looking $\mathrm{Fe}^{\circ}-\mathrm{Cr}^{\circ}$ metallic phase that follows the grain boundaries of the other oxide phases)....................6 68

Figure 4-32 Phase morphology and composition of K-3 refractory showing a spherical $\mathrm{Fe}^{\circ}$ component

Figure 4-33 Phase contrast SEM with semi-quantitative area measurements of each phase. The smallest phase indicated by the darkest color on the far right of each graph represents metallic Fe 70 


\section{LIST OF ABBREVIATIONS}

\begin{tabular}{|c|c|}
\hline ARP & Actinide Removal Process \\
\hline ASTM & ASTM International \\
\hline CEF & Cold-cap Evaluation Furnace \\
\hline СРC & Chemical Processing Cell \\
\hline СРP & Cyclic Potentiodynamic Polarization \\
\hline CR & Corrosion Rate \\
\hline DWPF & Defense Waste Processing Facility \\
\hline EDS & Energy Dispersive Spectroscopy \\
\hline EW & Equivalent Weight \\
\hline GA & Glycolic Acid \\
\hline HLW & High Level Waste \\
\hline IGA & Intergranular Attack \\
\hline K-3 & Monofrax ${ }^{\mathrm{TM}} \mathrm{K}-3$ Refractory \\
\hline LCM & Laser Confocal Microscope \\
\hline LPPP-PPT & Low Point Pump Pit Precipitate Pump Tank \\
\hline LPR & Linear Polarization Resistance \\
\hline mpy & Mils per year \\
\hline MCU & Modular Caustic-side Solvent Extraction Unit \\
\hline MFT & Melter Feed Tank \\
\hline MWWT & Mercury Wash Water Tank \\
\hline OCP & Open Circuit Potential \\
\hline OGCT & Off Gas Condensate Tank \\
\hline PRFT & Precipitate Reactor Feed Tank \\
\hline REDOX & Reduction/Oxidation Reaction \\
\hline RCT & Recycle Collection Tank \\
\hline SA & Surface Area \\
\hline SCE & Saturated Calomel Electrode \\
\hline SCM & Small Cylindrical Melter \\
\hline SEFT & Strip Effluent Feed Tank \\
\hline SEM & Scanning Electron Microscope \\
\hline SME & Slurry Mix Evaporator \\
\hline SMECT & Slurry Mix Evaporator Condensate Tank \\
\hline SRAT & Slurry Receipt Adjustment Tank \\
\hline SRNL & Savannah River National Laboratory \\
\hline
\end{tabular}




\subsection{Introduction}

Savannah River Remediation (SRR) is evaluating a new alternate reductant flowsheet for the Defense Waste Processing Facility (DWPF), specifically a nitric acid-glycolic acid flowsheet [1]. To implement the change in the facility, the current systems and components that were used to supply the $90 \mathrm{wt} \%$ formic acid will be used to supply the $70 \mathrm{wt} \%$ glycolic acid to the facility. Some glycolate anion will be sent to downstream facilities through the DWPF recycle stream. DWPF requested a corrosion assessment for the components of the DWPF facility and the other high level waste (HLW) and low level waste processing facilities that would be exposed to glycolic acid or glycolate salts [2].

The DWPF vessels and components as well as downstream facilities that would be in contact with glycolic acid or glycolate salts are shown in Attachment 1. Attachment 1 includes for the various components the temperature, $\mathrm{pH}$ limits, the materials of construction, worst case concentrations of glycolic acid or the glycolate anion, as well as a waste category.

A literature review was conducted and showed that there is insufficient corrosion data available to assess the impact of glycolic acid on the DWPF and downstream facilities [3]. Data on the material compatibility with just glycolic acid or its derivative products was identified; however, data on solutions of glycolic acid with other species present in the DWPF, Tank Farm, and Modular Caustic Side Solvent Extraction Unit (MCU) facilities was limited. Corrosion testing was necessary to provide data to evaluate the corrosion compatibility for the specific materials of construction and expected service conditions.

The testing consisted of:

- electrochemical testing in simulants pertinent to DWPF and downstream facilities,

- hot wall testing to simulate heat transfer surfaces for the SRAT/SME heating coils, the HLW evaporators and the heating coils for the Effluent Treatment Facility (ETF),

- polymer testing for the gasket and o-rings throughout the system especially the MCU, and

- coupon testing during the Cold-cap Evaluation Furnace (CEF) and the Chemical Processing Cell (CPC) scale-up testing $[4,5]$.

The polymer testing was conducted as part of the evaluation of the new solvent for MCU [6]. The results from the electrochemical, hot-wall, and coupon tests are presented and discussed in this report.

\subsection{Experimental Methods}

The tests for material compatibility to glycolic acid-containing solutions included electrochemical testing to evaluate the slurry receipt adjustment tank (SRAT), condensate and recycle solutions, hot-wall test for simulating conditions of heat transfer, coupon testing associated with other alternate reductant testing, i.e. the CEF and CPC (22 liter and large scale) testing. An assessment of operating conditions for various vessels and piping in DWPF and downstream facilities, which is shown in Attachment 1, was performed by DWPF facility engineering and Savannah River National Laboratory (SRNL).

The test matrices for the electrochemical and hot-wall testing given in Attachment 2 were based on the conditions listed in Attachment 1. The different glycolate concentrations used in this testing were based on previous testing or assumed worst case. The coupon test consisted of only a few materials of construction exposed to the conditions established by the other test matrices in the CEF and CPC testing $[4,5]$.

\subsection{Solution Chemistry}

The test solutions were made to simulate the wastes that are in various facilities or vessels. The solutions were placed into eight categories for electrochemical and hot-wall testing and are shown in Table 2-1, 
which also lists the representative facility or vessel. The target make-up solution chemistries are shown in Attachment 3. Actual quantities varied in a range of the $\pm 0.0003 \mathrm{~g}$ from the values listed.

Table 2-1 Solution Categories Used for Electrochemical and Hot Wall Testing

\begin{tabular}{||c|l|l||}
\hline Category & Solution Description & Facility/ Vessels \\
\hline 1 & Glycolic acid & DWPF acid feed tanks and piping \\
\hline 2 & SRAT/SME supernate & SRAT and SME vessel and components \\
\hline 3 & SRAT/SME condensate & SMECT \\
\hline 4 & DWPF acidic recycle & OGCT/RCT/Tank 22 \\
\hline 5 & Basic concentrated recycle & Tanks 38 and 43/ 2H Evaporator/Transfer lines \\
\hline 6 & Salt processing & Tanks 49 and 50/ Saltstone/ARP/MCU/Transfer lines \\
\hline 7 & Boric acid & MCU strip contactors \\
\hline 8 & Dilute waste & ETF condensate and Saltstone \\
\hline \hline
\end{tabular}

\subsubsection{Glycolic Acid}

The glycolic acid was tested at 70\% concentration and was used as provided by the supplier (stock bottle, reagent grade). This concentration is the same planned for use in DWPF. For the remaining solutions, sodium glycolate was added to provide the glycolate anion.

\subsubsection{SRAT/SME Supernate}

The supernate chemistry of the SRAT and the slurry mix evaporator (SME) tanks was based on results from experiments conducted during the trials on the efficacy of glycolic acid as an alternate reductant [1]. This nominal chemistry was provided by the Environmental Stewardship organization within SRNL. The solutions were made with sodium salts and a range of nitrate-based salts (see Attachment 3 for chemicals used in making solution). Three variants of this chemistry were made with changes in the iron concentration and aggressive species (chloride, sulfate, and mercury). Iron is known to impact the corrosion resistance of some materials in the presence of glycolic acid [3]. The variants were: (1) low iron $(0.001 \mathrm{M})$ and low aggressive species (0.023M chloride, $0.027 \mathrm{M}$ sulfate, and no mercury) concentrations (referred to as 'a'); (2) low iron and high aggressive species concentrations (referred to as 'b'); and (3) high iron (0.009 M) and high aggressive species concentrations (referred to as 'c'). The aluminum concentration was adjusted with the iron such that the total molar concentration of these two species was maintained constant. The high levels for chloride $(1 \%)$ and sulfate $(0.058 \mathrm{M})$ were used at WAC limits for DWPF [7]. The mercury concentration (added as mercury nitrate) was initially set at the WAC limit (21 g/L), but was found to lead to excessive precipitates, so the level was decreased to a quantity that was just soluble $(\sim 0.03 \mathrm{M})$ (.

\subsubsection{SRAT/SME Condensate}

The SRAT/SME condensate solution was based on analysis performed in 2004 and a more recent 2014 analysis $[8,9]$. The primary anions and cations in the slurry mix evaporator condensate tank (SMECT) samples were nitrate, formate, iron and mercury along with smaller concentrations of sulfate, chloride, aluminum and silicon. The silicon, which was believed to be associated with the use of the antifoaming agent in the SRAT, was not included. Silicates can be inhibitive so leaving them out made the test solution more conservative. The sodium glycolate concentration was based on results from CPC testing which found glycolate levels between 60 and $180 \mathrm{mg} / \mathrm{L} \mathrm{[10],} \mathrm{so} \mathrm{the} \mathrm{higher} \mathrm{level} \mathrm{was} \mathrm{used} \mathrm{for} \mathrm{this} \mathrm{testing.}$ For tests without glycolate present, glycolate was not added during make up without any other changes to the solution chemistry. 


\subsubsection{DWPF Acidic Recycle}

The DWPF acidic recycle was based on analysis performed for both the off-gas condensate tank (OCGT) and the recycle collection tank (RCT) $[9,11]$. Within this category the $\mathrm{pH}$ varied from being acidic to alkaline. At the neutral and low $\mathrm{pH}$ conditions, the OCGT analyses were used to formulate the solution chemistry. At the higher $\mathrm{pH}$ solution the RCT analysis was used. The primary constituents of the OCGT chemistry were aluminum, iron, manganese, nitrate, sulfate, fluoride and chloride. Silicon was also identified but not used due to the inhibitive actions of silicates. For the RCT, the primary constituents were similar; except nitrite and formate were also present and fluorides were not. Concentrations greater than $0.5 \mathrm{mg} / \mathrm{L}$ were generally taken as not having an effect on the corrosion. The glycolate concentration was taken at the bounding concentration of $10 \mathrm{~g} / \mathrm{L}$ [12]. For test without glycolate present, glycolate was not added during make up without any other changes to the solution chemistry.

\subsubsection{Basic Concentrated Recycle}

The basic concentrated recycle chemistry was based on that previously used for the testing of the impact of glycolate on the $2 \mathrm{H}$ evaporator system [13]. These chemistries were based on chemical analysis of samples from Tank 43. The low hydroxide chemistry was used to reach the desired $\mathrm{pH}$ of 13 . The glycolate concentration was taken at the bounding concentration of $10 \mathrm{~g} / \mathrm{L}$ [12]. For test without glycolate present, glycolate was not added during make up without any other changes to the solution chemistry.

\subsubsection{Salt Processing}

The salt processing solutions were based on sample analyses for Tanks 49 and 50, which are the feed tanks for the ARP (Actinide Removal Process) /MCU and Saltstone facilities, respectively [14, 15]. Tank 49 analyses (samples for salt batches 6-D, 7, and 7-A) showed higher concentrations than those for Tank 50 so these analyses were used to derive solution chemistries. The average value was used for most constituents, except chloride and sulfate where the higher values were used. Since the desired $\mathrm{pH}$ was 13, aluminum hydroxide was left out of the solution to avoid precipitate formation. The glycolate concentration was taken at the bounding concentration of $10 \mathrm{~g} / \mathrm{L}$ [12]. For test without glycolate present, glycolate was not added during make up without any other changes to the solution chemistry.

\subsubsection{Boric Acid}

The boric acid test solution was representative of the liquid that wet the MCU strip contactors. The concentration was $10 \mathrm{mM}$. The glycolate concentration was taken at the bounding concentration of 10 $\mathrm{g} / \mathrm{L}$ [12]. For test without glycolate present, glycolate was not added during make up without any other changes to the solution chemistry.

\subsubsection{Dilute Waste}

The dilute waste category was based on analysis of overhead samples from the $2 \mathrm{~F}, 2 \mathrm{H}$ and $3 \mathrm{H}$ evaporators [16]. This chemistry was principally associated with the condensate vessels and piping of the waste evaporators as well as the ETF. The primary constituents of this test solution were nitrate, nitrite, sulfate, oxalate, carbonate, chloride, calcium, iron, mercury, potassium, magnesium, ammonia and silicon. The high values were used for all constituents, except ammonia and silicon. Silicon was not used due to the inhibitive actions of silicates. Due to the limitations on the cations, the ammonia concentration was less than the high level. The $\mathrm{pH}$, which ranged from 3 to 12, was adjusted by the addition of nitric acid or sodium hydroxide, respectively. The other constituents were not varied. The glycolate concentration was $0.033 \mathrm{~g} / \mathrm{L}$, which was based on the analysis that the evaporator feed concentration of glycolate was $10 \mathrm{~g} / \mathrm{L}$, and the partitioning of soluble species to the overheads gave a maximum glycolate concentration of 0.033 $\mathrm{g} / \mathrm{L}$ [16]. For testing without glycolate, the glycolate was not added and no other constituent adjustments were made. 


\subsection{Materials}

The materials for the test samples were based on a review of the materials of construction for piping, jumpers, vessels and tanks both within DWPF and downstream facilities which included the tank farms, ARP, MCU, ETF and Saltstone as given in Attachment 1. Samples were generally obtained from Metal Samples, Inc. (Munford, AL). The material Astralloy® (Astralloy) was cut from a Saltstone mixer blade and the Stellite ${ }^{\circledR}$ 6B (Stellite) sample was taken from stock material stored at the lab. The material compositions for the electrochemical samples were verified through $\mathrm{x}$-ray fluorescence and are shown in Table 2-2. The material composition for the hot wall test samples were verified with certified material test reports and were similar to those reported below. All samples were prepared with a final surface finish from 600-grit grinding paper.

Table 2-2 Material Compositions for Electrochemical Test Samples

\begin{tabular}{|c|c|c|c|c|c|c|c|c|c||}
\hline \hline Material & Cr & Ni & Fe & Mn & Mo & Si & W & Co & Other \\
\hline C276 & 15.5 & 57.8 & 6.3 & 0.5 & 14.2 & 0.3 & 3.3 & 1.8 & \\
\hline 316L & 16.4 & 10 & 65.6 & 1.7 & 2.1 & 0.5 & - & 0.2 & $0.2 \mathrm{Cu}$ \\
\hline 304L & 18.5 & 8.8 & 69.7 & 1.8 & 0.2 & 0.5 & - & - & $0.3 \mathrm{Cu}$ \\
\hline Stellite ${ }^{\circledR} 6$ & 30.4 & 2.3 & 2.1 & 1.6 & 0.8 & 0.5 & 4 & 57.2 & \\
\hline Ultimet ${ }^{\circledR}$ & 25.2 & 9.2 & 3.2 & 0.8 & 5.1 & 0.4 & 2 & 53.9 & \\
\hline Astralloy ${ }^{\circledR}$ & 1.5 & 3.5 & 93 & 0.9 & 0.3 & 0.3 & - & - & $0.2 \mathrm{Cu}$ \\
\hline A537 & $<0.1$ & $<0.1$ & 97.7 & 1.3 & - & 0.4 & - & - & $0.2 \mathrm{Cu}$ \\
\hline A285 & - & - & 99.1 & 0.5 & - & 0.1 & - & - & \\
\hline G30 & 28.8 & 40.4 & 14.9 & 1.1 & 5 & 0.3 & 3.1 & 3.6 & $1.9 \mathrm{Cu}, 0.7 \mathrm{Nb}, 0.2 \mathrm{Al}$ \\
\hline G3 & 22.3 & 44 & 19.8 & 0.8 & 7.6 & 0.5 & 0.9 & 1.9 & $2 \mathrm{Cu}$ \\
\hline AllCorr ${ }^{\circledR}$ & 28.9 & Bal & 1.1 & - & 9.9 & 0.1 & 1.9 & & \\
\hline
\end{tabular}

\subsection{Electrochemical Testing}

The electrochemical testing was chosen as an accelerated method to determine if the glycolic acid would impact the localized corrosion resistance of the materials of construction as well to measure a general corrosion rate. The listing of test conditions is shown in Attachment 2, Table A2-1. The electrochemical testing followed the guidelines given in applicable ASTM International standards [17-20]. The electrochemical testing consisted of a series of individual tests including open-circuit potential measurement, linear polarization resistance and cyclic potentiodynamic polarization.

Open-circuit potential (OCP) monitoring was used to follow the equilibration of the sample in the test solution and varied from one hour up to a maximum of three hours. In some cases the sample had not fully equilibrated within the three-hour period. Immediately at the end of the OCP monitoring, linear polarization resistance (LPR) was performed to determine a general corrosion rate. This test involves application of a scanning potential ramp $(0.2 \mathrm{mV} / \mathrm{sec})$ over a potential range of $+/-15 \mathrm{mV}$ around the OCP. From the plot of the potential and resulting current, a polarization resistance value $\left(R_{p}\right)$ is determined and Equation 1 is used to calculate a general corrosion rate (CR) of the material.

$\mathrm{CR}=3.2710^{3} \times \mathrm{B} \times \mathrm{EW} /\left(\mathrm{R}_{\mathrm{p}} \times \rho \times \mathrm{SA}\right)$

\{Equation 1\}

where B is a constant related to the electrochemical behavior of the material in the environment, 0.026 for this testing; EW is the equivalent weight (g) of the material; $\rho$ is the material density $\left(\mathrm{g} / \mathrm{cm}^{3}\right)$; and SA is the surface area of the sample $\left(\mathrm{cm}^{2}\right)$. The material values are given in Table 2-3.

At the conclusion of the LPR, a cyclic potentiodynamic polarization (CPP) was performed to assess the susceptibility to localized corrosion. This technique applies a similar potential ramp as the LPR technique 
$(0.2 \mathrm{mV} / \mathrm{sec})$, but over a larger potential range $(+1.0 \mathrm{~V})$ away from the OCP along with a reverse scan back to the OCP. The potential/responding current plot provides data on the passivity and susceptibility to pitting, crevice corrosion and stress corrosion cracking.

The electrochemical tests were performed using Ametek PAR Model 273A potentiostat/galvanostats in conjunction with a laptop computer and Scribner Associates Inc. CorrWare ${ }^{\circledR}$ software. The test cell consisted of borosilicate glass five-port flasks with a standard three-electrode set up: a reference, counter and working electrodes. The counter electrode was 0.25 -inch diameter graphite rod, while the reference electrode was a saturate calomel electrode (SCE, $+0.243 \mathrm{mV}$ vs Normal Hydrogen Electrode). All potentials in this report are given in reference to the SCE potential. Prior to each test, the reference electrode potential was verified against that of an unused reference maintained in a saturated potassium chloride solution. The reference electrode was place in a salt bridge containing $0.1 \mathrm{M}$ sodium nitrate solution. In tests greater than $50{ }^{\circ} \mathrm{C}$, water-cooled salt bridges were used to maintain the reference electrode at a constant value.

Table 2-3 Material Values for Determining Corrosion Rate

\begin{tabular}{|c|c|c|c|}
\hline Material & $\begin{array}{c}\text { Surface Area* } \\
\left(\mathrm{cm}^{2}\right)\end{array}$ & $\begin{array}{c}\text { Density } \\
\left(\mathrm{g} / \mathrm{cm}^{3}\right)\end{array}$ & $\begin{array}{c}\text { Equivalent } \\
\text { Weight }\end{array}$ \\
\hline 316L & 2 & 7.98 & 25.50 \\
\hline Astralloy & 1.5 & 7.85 & 27.65 \\
\hline 304L & 3 & 7.96 & 25.12 \\
\hline Stellite & 2 & 8.52 & 25.38 \\
\hline C276 & 2 & 8.8 & 27.09 \\
\hline Ultimet & 3.5 & 8.47 & 25.34 \\
\hline A537 & 1.5 & 7.86 & 27.9 \\
\hline A285 & 2.9 & 7.86 & 27.9 \\
\hline G30 & 2.5 & 8.22 & 23.99 \\
\hline G3 & 3 & 8.14 & 25.51 \\
\hline
\end{tabular}

* Approximate values

The potentiostat performance was verified following the test guidelines given in ASTM International G5 standard test method [17]. The data shown in Figure 2-1 for one of the potentiostats demonstrates that for a standardized test condition (430 stainless steel in de-aerated $1 \mathrm{~N}$ sulfuric acid at $30{ }^{\circ} \mathrm{C}$ ) the measured currents are within the acceptable minimum and maximum ranges both prior to and at the conclusion of testing. The other potentiostats had similar acceptable behavior.

The working electrode was one of the candidate materials of construction. Each sample had a Teflon ${ }^{\circledR}$ coated copper wire attached to the back with a conductive silver epoxy. The sample was then placed in a metallurgical mount with fast-set epoxy. The mount exposed one surface of the sample for testing and facilitated surface preparation with 600 grit silicon carbide paper prior to testing. Samples were used multiple times and prepared prior to the start of each test by grinding on 600 grit paper and rinsing with the following sequence - water, acetone, water - then blowing dry.

Test solutions were prepared just prior to performing the test and prepared in $1.2 \mathrm{~L}$ batches. Approximately $600 \mathrm{ml}$ of solution was used for each test. Each test condition, i.e. temperature, solution chemistry, material, was performed in duplicate. All duplicate tests were not performed with the same batch of solution, which contributed to some of the data variability. At the conclusion of testing, some 
deposits were generally seen in the bottom of the test cell. Measurement of the solution $\mathrm{pH}$ was made before and after each test.

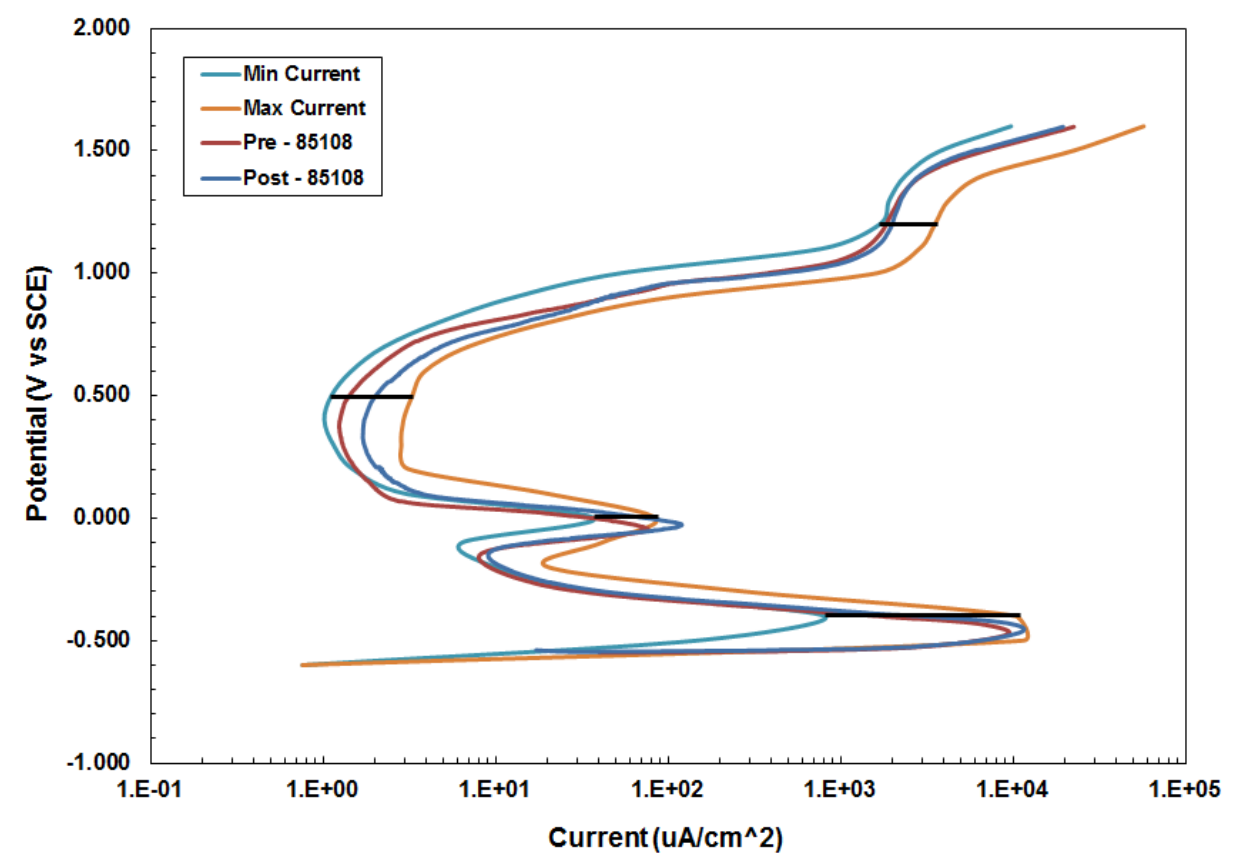

Figure 2-1 Polarization results from a ASTM G5 standardized test performed with potentiostat SN 85108 that was used during the alternate reductant testing

Tests were generally performed without mixing or bubbling of air. The natural convection of solutions due to heating from the bottom provided for solution mixing, especially at boiling conditions. For the testing with the SMECT solution, air was bubbled into the solutions since air is bubbled into the SMECT when solids need to be suspended.

At the conclusion of the test, the samples were examined for corrosion. Pictures were taken on a laser confocal microscope (LCM) along with scans for characterizing any observed pitting (pit depths).

\subsection{Hot-Wall Testing}

Hot-wall corrosion tests are performed to determine corrosion rates for materials exposed to solutions under heat transfer conditions. The hot-wall test was discussed in greater detail in Reference 21 . The hot wall apparatus is shown in Figure 3-2. The sample is clamped in position with the heater block on one side and the glass vessel, which contains the solution, on the other. A Viton gasket is used to form the seal between the sample and the glass vessel. Solution quantities were limited to $500 \mathrm{ml}$ to minimize the generation of hazardous solutions. Solution levels dropped during testing due to evaporation and were replenished on an alternating schedule between fresh solution and distilled water so as not to concentrate constituents.

The heater blocks were operated at full power to generate a maximum temperature on the sample surface. A thermocouple was placed through a port on the glass vessel so as to just touch the sample surface. Thermocouples, which plugged into the heater block, were used to control the operation of the heater. Once at temperature, the tests were conducted for times between 22 and 34 days. 
Testing was performed on materials of construction for the heating coils for the SRAT/SME (C276 and Ultimet), the tube bundles and warming coils for the $2 \mathrm{H}$ evaporator (G30) and the heater for the ETF evaporator (G3). The test matrix is shown in Attachment 2, Table A2-2. Samples, which were procured from Metal Samples (Munford, AL), had surfaces prepared with a 600 silicon carbide paper. Samples were 3-inch diameter and had a thickness of 1/8 to 1/16 inch. Samples were weighed prior to testing and after cleaning at the conclusion of the test in order to calculate a weight loss for a general corrosion rate measurement. The solutions used to clean the samples after testing were nitric acid solutions from $0.1 \mathrm{M}$ up to $1.0 \mathrm{M}$. At the conclusion of the hot-wall test and after cleaning, the samples were examined for corrosion using a LCM. Laser scans were taken to characterize any localized corrosion.

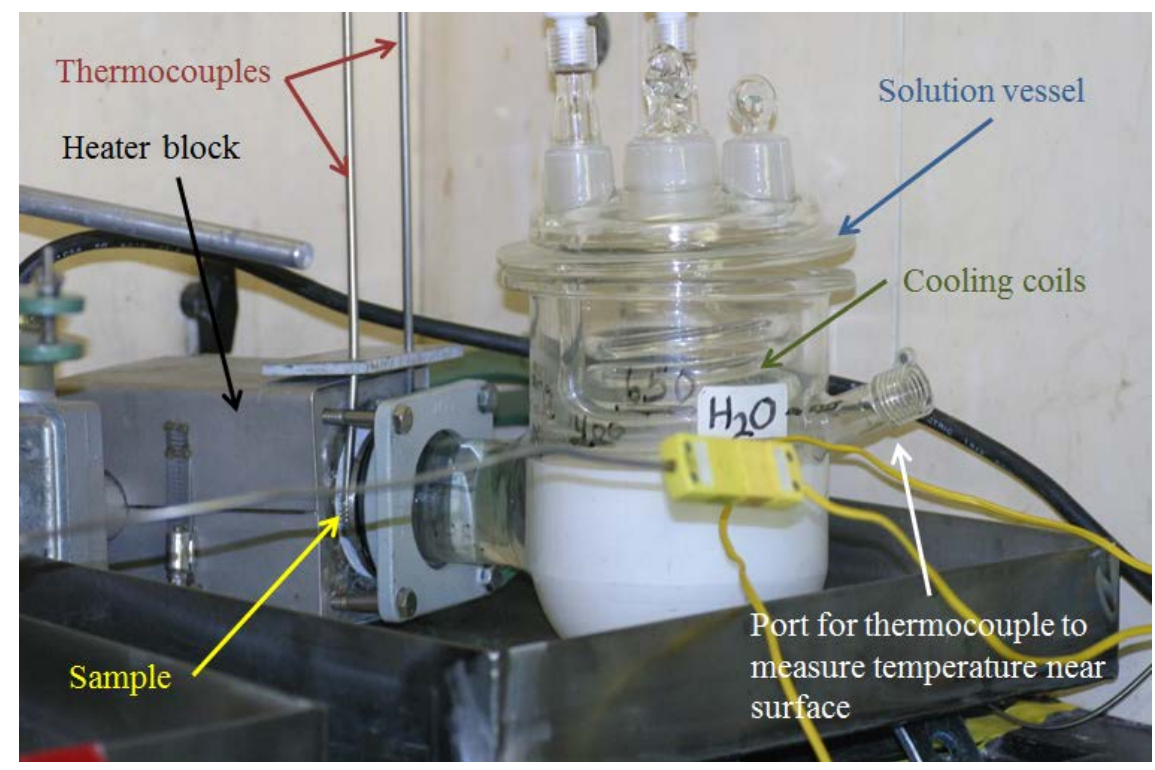

Figure 2-2 Hot-wall test apparatus for corrosion testing under heat transfer conditions

\subsection{Coupon Testing}

The coupon testing was performed in conjunction with other tests evaluating the impact of glycolic acid on the flowsheet (scaled demonstrations of the CPC) and the melter (CEF testing).

\subsubsection{CEF Test}

The CEF testing was conducted to evaluate the off-gas flammability, surge potential and cold cap behavior of the nitric-glycolic flowsheet over the course of a 25-day test period. Two acid stoichiometry melter feeds were evaluated (100\% and 125\%) and the total solids loading was varied between 42 and 49\%. The melter feed was produced by combining Harrell Industries SB6I Sludge Receipt and Adjustment Tank (SRAT) product with dry Frit 418 at a target waste loading of $36 \%$ and additional nitric or glycolic acid to adjust the reduction/oxidation (REDOX). Depending on the test conditions additional water was added to yield the desired total solids content. An antifoam spike was also used during a portion of the test. Throughout the testing, the average temperature of the melt pool was maintained near $1030{ }^{\circ} \mathrm{C}\left(800-1100{ }^{\circ} \mathrm{C}\right)$, while the temperature of the vapor space region was varied between 270 and $750{ }^{\circ} \mathrm{C}$. Two L-shaped bubblers were positioned to 1 inch above the melter floor and oriented slightly off of the center. Ar-bubbling was adjusted between 0.01 and 1 standard cubic feet/minute (scfm).

Test sample materials included Inconel ${ }^{\circledR} 690$ (I690) and Monofrax ${ }^{\mathrm{TM}} \mathrm{K}-3$ (K-3). I690 was supplied as an approximately 3 foot long, 3/4 inch diameter, schedule 120 pipe. The pipe was installed in the melter as a 
bubbler, which was exposed in all regions of the melter (vapor space, melt line and melt pool). The K-3 refractory block was an old qualification block from a previous DWPF melter. A test coupon, 4 inch by 1 inch by 0.5 inch, was sectioned from the denser exterior surface. The K-3 coupon was secured to the bubbler at the melt line using an I690 cage. At the conclusion of the CEF test, the I690 bubbler and the pieces of K-3 were removed and examined for corrosion and degradation. The evaluations used light microscopy, scanning electron microscopy (SEM), and energy dispersive spectroscopy (EDS).

\subsubsection{CPC 22-L Test}

For the scaled demonstration testing for the CPC in the 22L vessel, two C276 coupons were installed to monitor for localized corrosion. The coupon rack is shown in Figure 2-3. The coupon rack was a 316L stainless steel rod machined so that the coupons would not protrude beyond the 1-inch diameter of the rod. The rack was put into a port where a redundant heating rod was located. The coupons were oriented parallel to flow. The coupons were attached to the rack with Teflon spacers and crevice washers to facilitate crevice corrosion, if likely to occur under these conditions.

Two runs were performed that lasted approximately 85 hours each. Temperatures were ramped up from room temperature to $102{ }^{\circ} \mathrm{C}$ (boiling). The coupons were removed from the test vessel between test, rinsed and wiped off. The two runs had different nitric/glycolic acid ratios and slightly different quantities of sludge. At the end of the 22L testing, the coupons were removed from the test cells, rinsed and dried. Coupons were photographed both before and after cleaning. The cleaning consisted of a 5minute short soak in a $0.1 \mathrm{M}$ nitric acid solution, rinsing with distilled water, rinsing with ethyl alcohol and blowing dry. After cleaning the coupons were weighed.
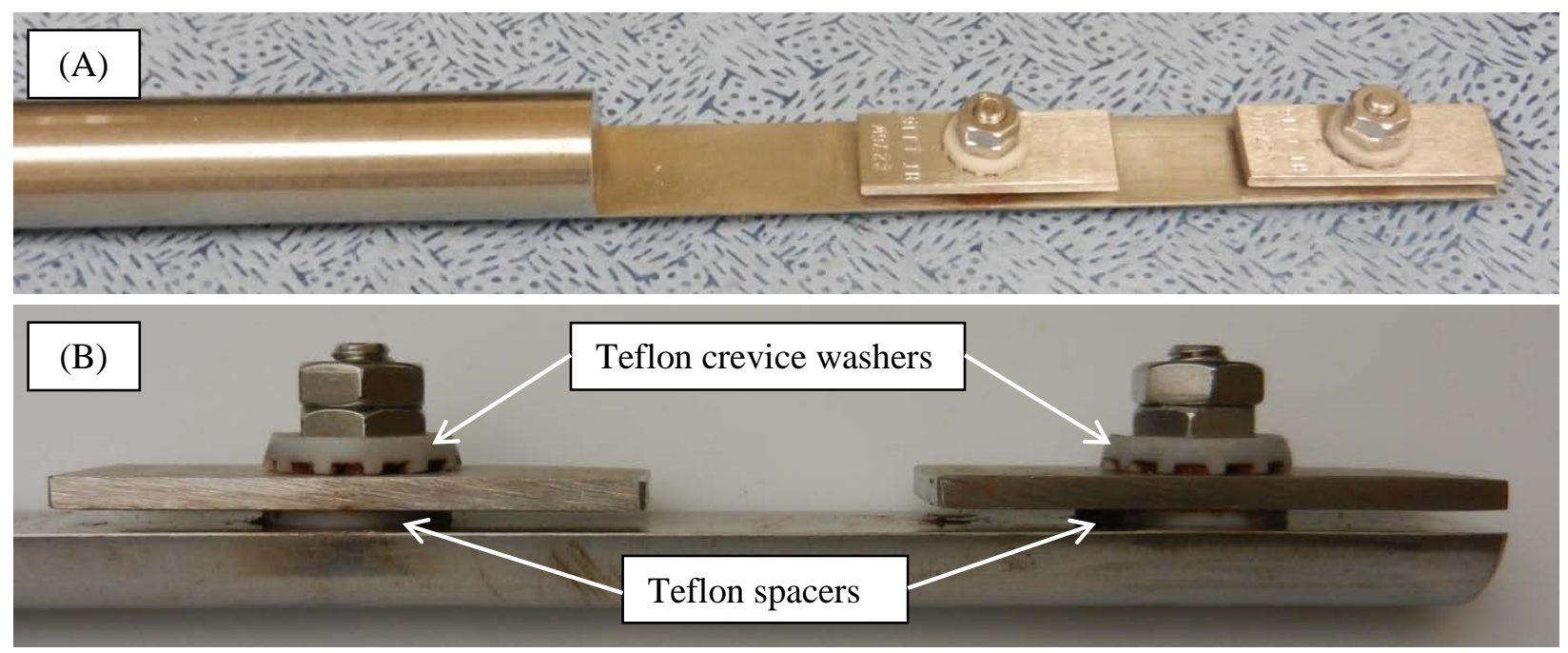

Figure 2-3 Coupon rack used for scale demonstration testing of the CPC in the 22L vessel: (A) top view and (B) side view

\subsection{Results and Discussion - Non-Melter Materials of Construction}

The results from the electrochemical, hot wall and 22-L CPC coupon test are presented and discussed in this section for all the materials of construction except those associated with the melter. The CEF coupon test results for the melter materials of construction, I690 and K-3, are presented and discussed in Section 4. 


\subsection{Electrochemical Tests}

The results from the electrochemical testing will be discussed by the category, which are shown again in Table 3-1 along with the materials of construction tested for that category.

Table 3-1 Solution Categories Used for Electrochemical and Hot Wall Testing

\begin{tabular}{|c|l|l|}
\hline Category & Solution Description & Materials of Construction \\
\hline 1 & Glycolic acid & 304L, 316L \\
\hline 2 & SRAT/SME supernate & C276, 304L, Ultimet, Stellite \\
\hline 3 & SRAT/SME condensate & 316L \\
\hline 4 & DWPF acidic recycle & C276, AllCorr, 304L, A285 \\
\hline 5 & Basic concentrated recycle & 304L, 316L, G30, A537 \\
\hline 6 & Salt processing & 304L, 316L, A537, Astralloy \\
\hline 7 & Boric acid & 316L \\
\hline 8 & Dilute waste & 304L, A537, G3 \\
\hline
\end{tabular}

\subsubsection{Category 1 -Glycolic Acid}

Testing was conducted at $50{ }^{\circ} \mathrm{C}$ in $70 \%$ glycolic acid (GA) as supplied by the vendor (Sigma-Aldrich Co.). The measured $\mathrm{pH}$ was less than 1 . These tests were performed to simulate conditions in the DWPF storage and feed vessels and piping for the glycolic acid. The corrosion responses of 304L and 316L differed in glycolic acid. The test conditions and electrochemical parameters are shown in Table 3-2 and include the OCP at the end of potential monitoring, the corrosion rate (CR measured in mils per year (mpy)) calculated from the LPR test, the passive current $\left(\mathrm{i}_{\mathrm{P}}\right)$ measured at a potential $200 \mathrm{mV}$ more electropositive than the OCP, the hysteresis in the CPP scan, and any corrosion observed on the sample at the conclusion of testing.

Table 3-2 Electrochemical Parameters for 316L and 304L in Category 1 Solutions

\begin{tabular}{|l|c|c|c|c|c|c|l||}
\hline Material & GA & $\begin{array}{c}\text { Temperature } \\
(\mathbf{C})\end{array}$ & $\mathbf{O C P}(\mathbf{V})$ & $\begin{array}{c}\mathbf{C R} \\
(\mathbf{m p y})\end{array}$ & $\mathbf{i}_{\mathbf{P}} \mathbf{( \mathbf { A } / \mathbf { c m } ^ { 2 } )}$ & Hysteresis & Corrosion \\
\hline 316L & $70 \%$ & 50 & 0.185 & $<0.1$ & $1.8 \mathrm{E}-6$ & Negative & None \\
\hline 304L & $70 \%$ & 50 & $0.205 /-0.274$ & $0.2 / 6$ & $1.1 / 1.5 \mathrm{E}-6$ & Negative & Pitting \\
\hline
\end{tabular}

The 316L samples passivated within three hours and showed standard passive curves with negative hysteresis as shown in Figure 3-1. The samples showed no corrosion at the end of testing.

The 304L samples experienced two different states in the glycolic acid as indicated by the OCP measured during stabilization as shown in Figure 3-2. The sample had two potentials where it was quasi-stable: 0.2 $\mathrm{V}$ and $-0.28 \mathrm{~V}$. The potentials are identified as quasi stable since the potential shift to a more noble value did not always occur in the time monitored and the potentials may not have been monitored for sufficient time (i.e. $>4$ hours) to see if they reverted to the more active potential. The OCP, however, always started at the more active or electronegative potential. This transition may be associated with a buildup of the oxide film on the sample since the corrosion rate at the more active OCP is an order of magnitude higher as shown by the data in Table 3-2. Additionally, the cathodic reaction may change due to an increasing concentration of a different electroactive species, similar to carbon steel in sludge simulants with oxalic acid [52]. 


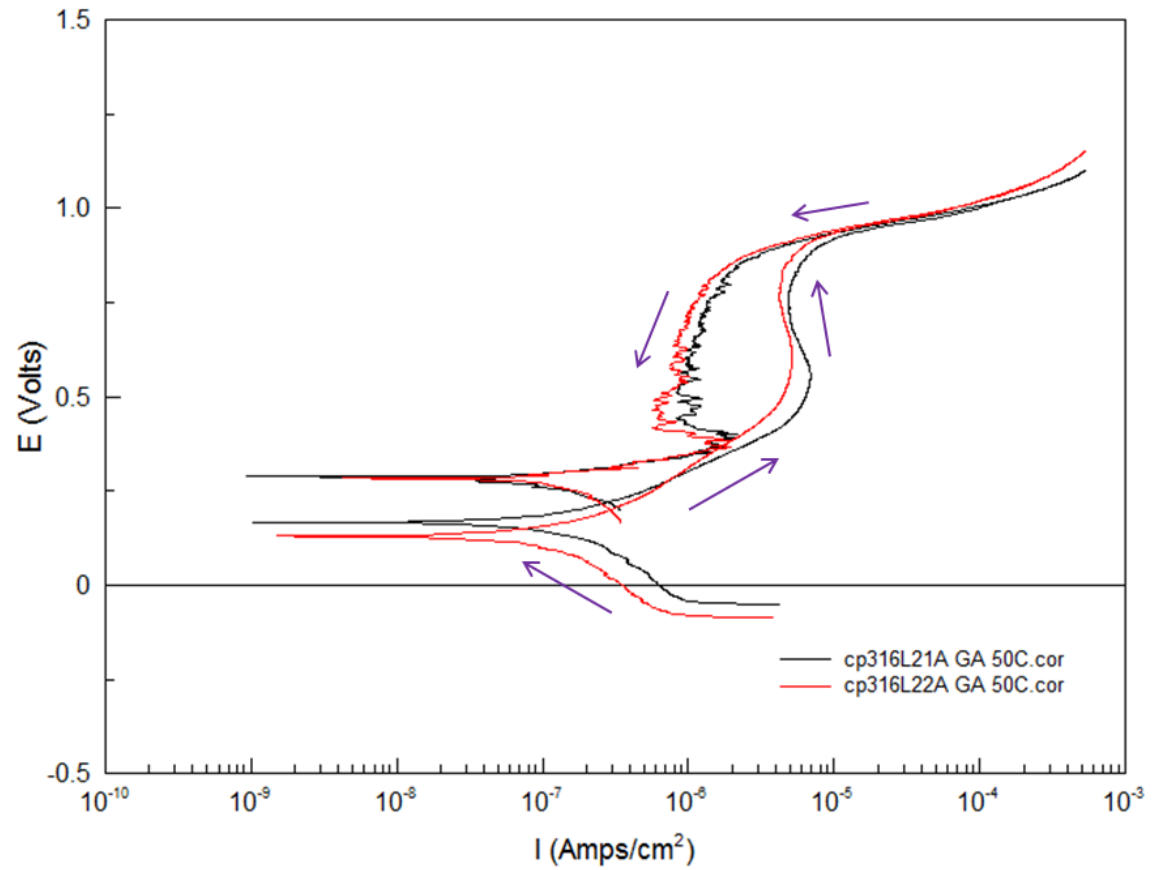

Figure 3-1 CPP scans of 316L in 70\% glycolic acid at $50{ }^{\circ} \mathrm{C}$ (arrows indicate direction of potential scan)

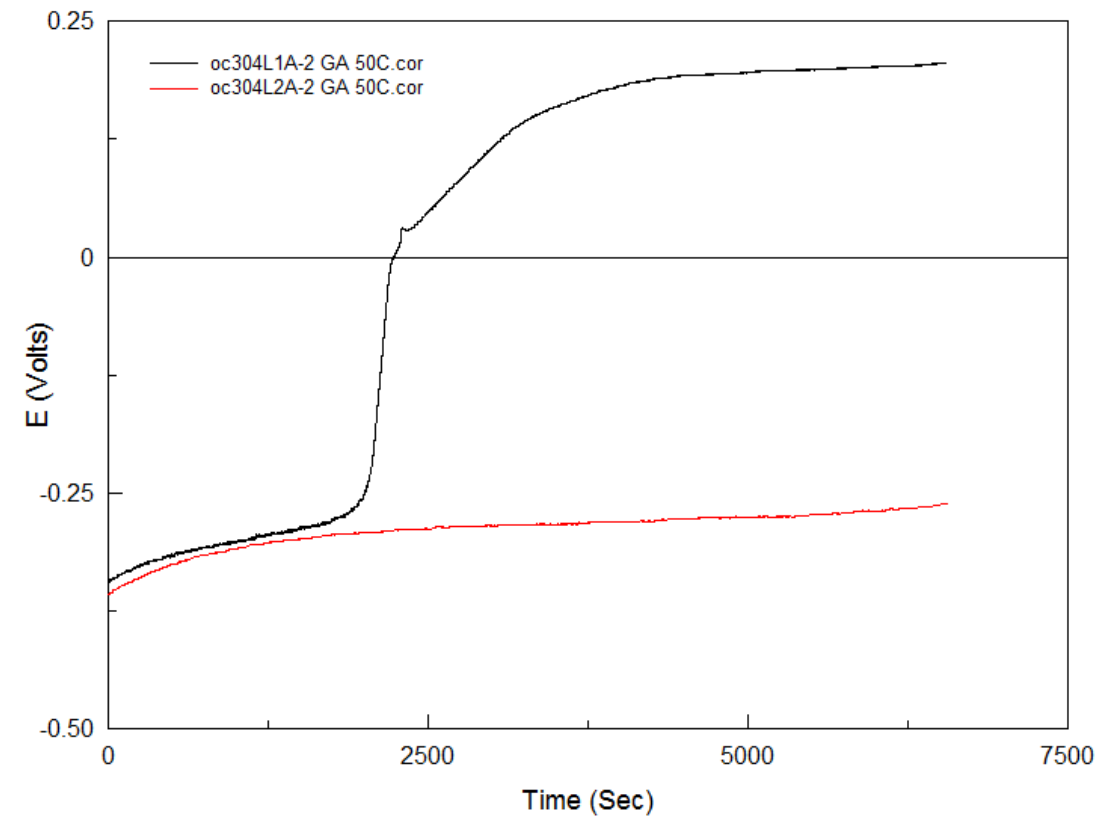

Figure 3-2 OCP versus time scans of $304 \mathrm{~L}$ in $70 \%$ glycolic acid at $50{ }^{\circ} \mathrm{C}$

The CPP scan differed for the two potentials although both indicated passive behavior as shown by the CPP scans in Figure 3-3. The CPP scan with the more active OCP has several anodic/cathodic transitions. The anodic region at the more passive or electropositive potentials is associated with the oxidation of the sample. The cause for the lower anodic portion is not known, but may be associated with the glycolate anion. Independent of the starting OCP a negative hysteresis was always obtained. Although the 
negative hysteresis indicates a lack of susceptibility to localize corrosion, both the samples associated with these CPP scans were found to have pits or pit-like features as shown by the images in Figure 3-4. Pit depth measurements were not made on these samples.

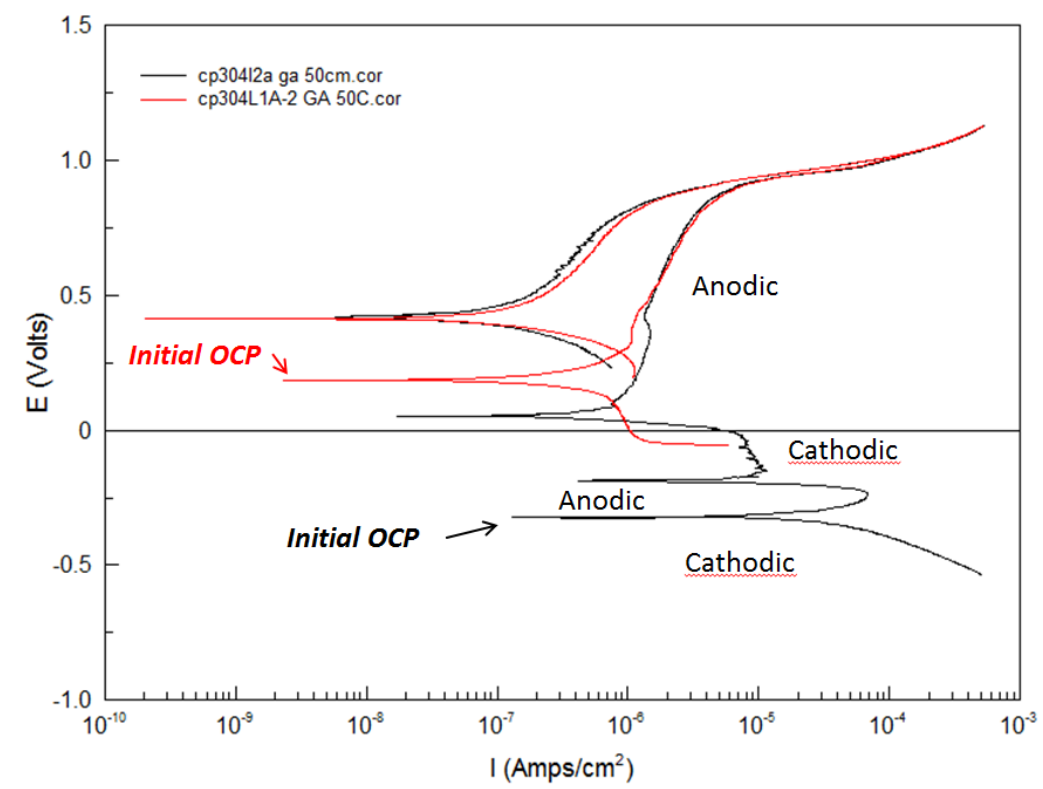

Figure 3-3 CPP scans of 304L in $70 \%$ glycolic acid at $50{ }^{\circ} \mathrm{C}$ with two different starting OCPs
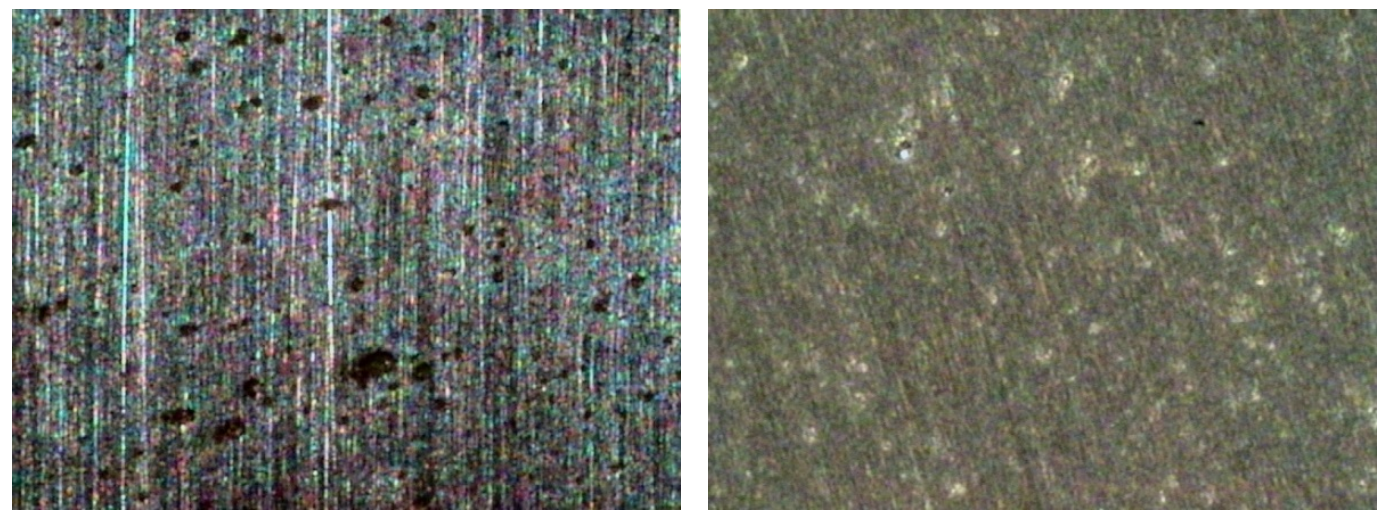

Figure 3-4 Stereomicroscope images for 304L samples taken after electrochemical testing in 70\% glycolic acid at $50^{\circ} \mathrm{C}$ : (A) 304L1A-2; and (B) 304L2A (CPP scans shown in Figure 3-3)

Several tests with 304L that were performed at room temperature showed only passivity and no indication of pitting. These tests were performed after the sample stabilized in the solution for eighteen hours. Similar to the higher temperature results during OCP monitoring, the potentials started out at more active values and transitioned to the passive values at approximately $0.26 \mathrm{~V}$. The corrosion rates varied with this change in potential as shown by the data in Table 3-1. The higher corrosion rate of 6 mpy exceeds the upper bound corrosion rate of 2 mpy for the current formic acid tanks (formic acid dilution tank and dilute formic acid feed tank) constructed of 304L [23]. Temperature of the glycolic acid therefore impacts the corrosion resistance of 304L.

The electrochemical results at $50{ }^{\circ} \mathrm{C}$ are not conclusive that localized corrosion will occur during service since pitting was observed with a negative hysteresis. Additional testing is recommended for $304 \mathrm{~L}$ at the 
actual service temperature of the formic acid feed vessels and piping. Coupon immersion test at service temperatures would provide necessary data if pitting will occur over an extended exposure in 304L that is contact with glycolic acid in the DWPF.

\subsubsection{Category 2 - SRAT/SME Supernate}

For Category 2 solutions, the electrochemical testing was difficult to conduct because high heat demand to maintain boiling temperatures set up a disruptive feedback to the electrochemical equipment. The initial planned test temperature of $103^{\circ} \mathrm{C}$ produced vigorous boiling. The boiling led to bubble formation in the tips of the salt bridge which disrupted the potential equilibration during OCP monitoring and potential tracking during the CPP tests, which lead to increased noise in the data or incomplete tests. Test temperatures were generally reduced to $99{ }^{\circ} \mathrm{C}$, but were set as low as $90^{\circ} \mathrm{C}$ in some cases to obtain stable, noise-free data. Another difficulty noted during testing was unexpected shifts in the corrosion potential as shown in Figure 3-5, which shows the potential shift for one sample (oc3cC95A). This same sample showed the potential spikes due to the bubbles.

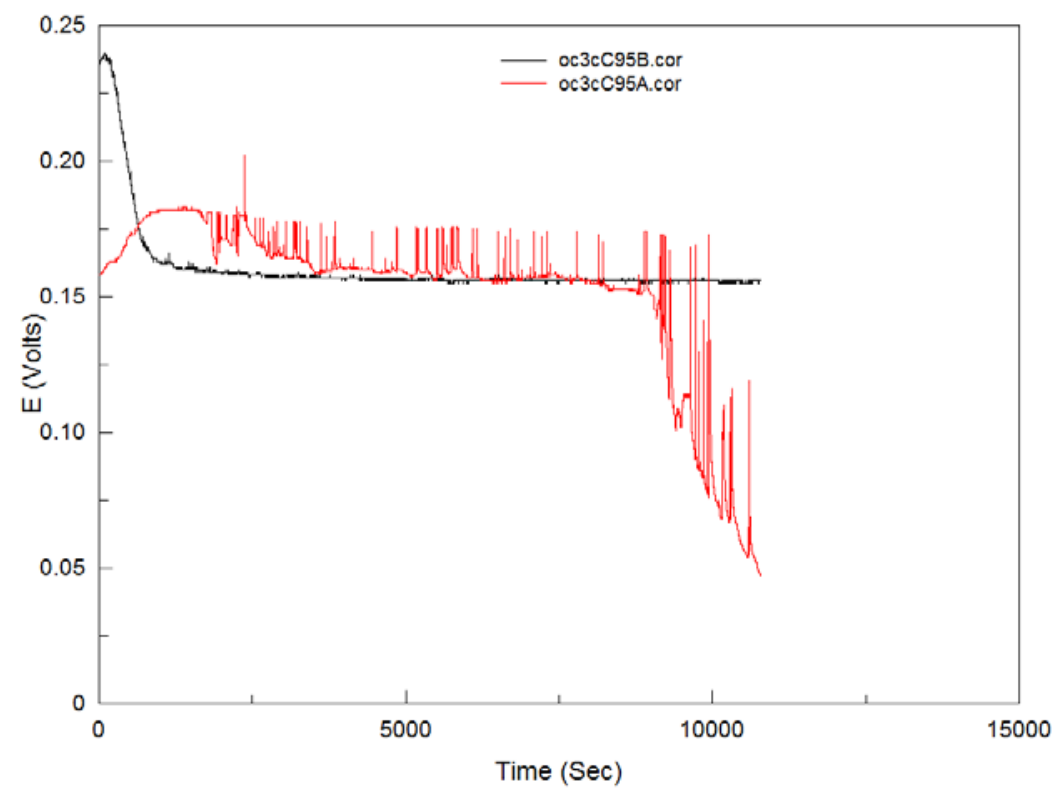

Figure 3-5 OCP monitoring of C276 in SRAT/SME supernate with sodium glycolate and high levels of iron and aggressive species at $95^{\circ} \mathrm{C}$

The overall shift of the OCP to more electronegative value is attributed to changes in the solution chemistry or reactions during the course of testing. A manifestation of these reactions was changes in solution coloring. For example, the solution for sample oc3cC95A changed from an initial yellow/brown color to bright yellow during the course of testing. These chemical reactions from the color change may have also attributed to CPP scans as shown in Figure 3-6 with shifts in current density as shown for sample cp9cC103B, which did not contain the glycolate anion.

The initial planned $\mathrm{pH}$ for the Category 2 solutions was 3, which is the minimum value for the vessels and piping within the CPC. However, for testing purposes the target $\mathrm{pH}$ for solutions with glycolic acid was 5 since the supernate chemistry used to make the test solutions was based on the flowsheet demonstration for the CPC using nitric and glycolic acids. This chemistry had sufficient buffering capacity that the solution chemistry would have been altered and not as representative of CPC solution chemistries if adjusted to a $\mathrm{pH}$ of 3 . 
The variability in these solutions was also shown by the solution $\mathrm{pH}$ as well as $\mathrm{pH}$ change during the course of testing. Solution $\mathrm{pH}$ values on makeup varied from approximately 4 to 5.6, although the additions of chemical quantities were nearly identical and $\mathrm{pH}$ meters were calibrated before each measurement. The $\mathrm{pH}$ of the solution after testing rose or lowered from as little as $0.03 \mathrm{pH}$ units and up to $1.3 \mathrm{pH}$ units from pre-test measurements. The initial $\mathrm{pH}$ of solutions not containing the glycolate anion ranged from 2.4 to 5 , with most solutions less than 3 .

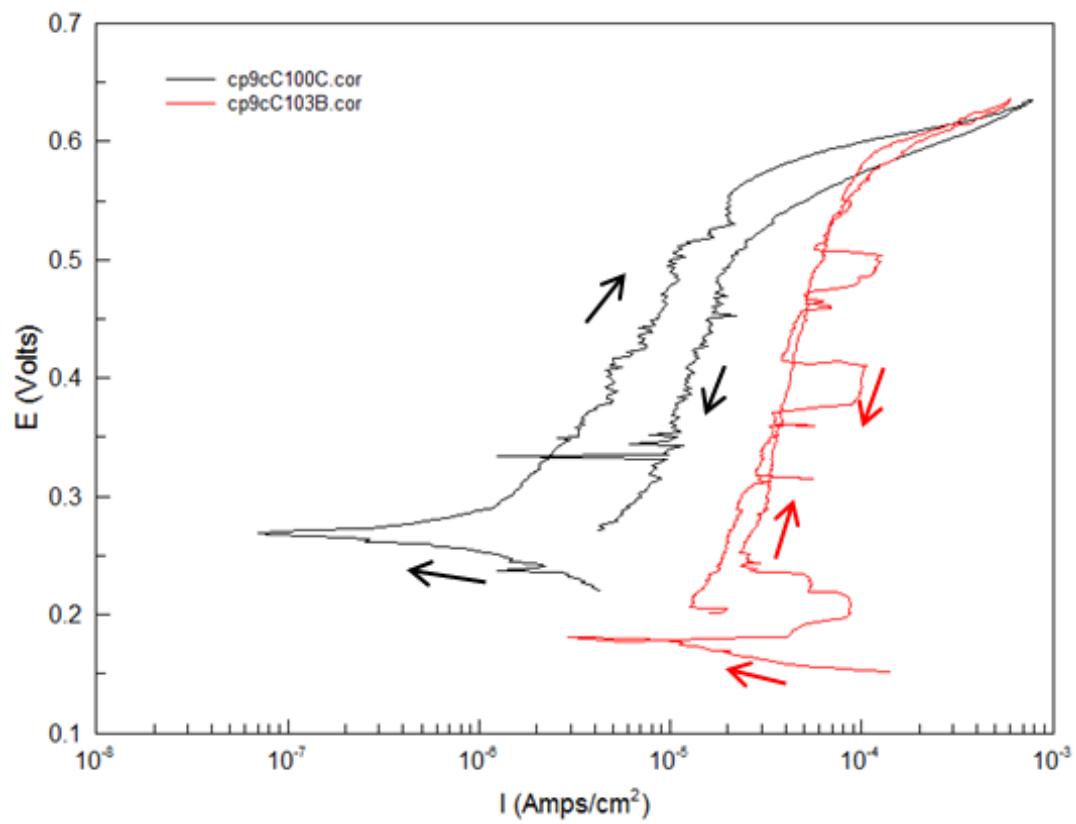

Figure 3-6 CPP scans of C276 in SRAT/SME supernate without sodium glycolate and with high levels of iron and aggressive species at $99^{\circ} \mathrm{C}$ (arrows indicate direction of potential scan)

The presence of glycolate in the SRAT/SME supernate impacted the corrosion behavior for these materials of construction. The test conditions and pertinent electrochemical parameters are summarized in Table 3-3 for C276 and in Table 3-4 for the other materials in the CPC cell. In these tables, a level of 'a' indicated low levels of $\mathrm{Fe}, \mathrm{Cl}^{-}, \mathrm{SO}_{4}{ }^{-2}$, and $\mathrm{Hg}$; 'b' indicated low level of $\mathrm{Fe}$ and high levels of $\mathrm{Cl}^{-}, \mathrm{SO}_{4}{ }^{-}$ ${ }^{2}$, and $\mathrm{Hg}$; ' $\mathrm{c}$ ' indicated high levels of $\mathrm{Fe}, \mathrm{Cl}^{-}, \mathrm{SO}_{4}{ }^{-2}$, and $\mathrm{Hg}$ (See Section 2.1.2 for complete details).

Table 3-3 Electrochemical Parameters for C276 in Category 2 Solutions

\begin{tabular}{|c|c|c|c|c|c|c|c||}
\hline $\mathbf{T ~}\left({ }^{\circ} \mathbf{C}\right)$ & GA & $\begin{array}{c}\text { Aggressive } \\
\text { Species }\end{array}$ & $\begin{array}{c}\text { OCP (V, } \\
\text { SCE) }\end{array}$ & $\begin{array}{c}\mathbf{C R} \\
(\mathbf{m p y})\end{array}$ & $\begin{array}{c}\mathbf{i}_{\mathbf{p}} \\
\left(\mathbf{A} / \mathbf{c m}^{2}\right)\end{array}$ & Hysteresis & Corrosion \\
\hline 100 & $0.65 \mathrm{M}$ & $\mathrm{a}$ & -0.136 & $0.6,0.7$ & $1.1 \mathrm{E}-5$ & Negative & Pitted \\
\hline 100 & $0.65 \mathrm{M}$ & $\mathrm{b}$ & 0.142 & $1.5,2.1$ & $7.7 \mathrm{E}-6$ & Positive & None \\
\hline 95 & $0.65 \mathrm{M}$ & $\mathrm{c}$ & 0.173 & 12.4 & $9.7 \mathrm{E}-6$ & Positive & None \\
\hline $95 / 100^{*}$ & 0 & a & $0.034 / 0.238$ & ND/1.8 & $\begin{array}{c}0.4 / 3 \mathrm{E}- \\
5\end{array}$ & Undefined & Corroded \\
\hline 100 & 0 & b & 0.231 & $0.2-11$ & $5.1 \mathrm{E}-6$ & Positive & Tarnished \\
\hline 100 & 0 & c & 0.273 & $0.6-11$ & $9.6 \mathrm{E}-6$ & Positive & None \\
\hline 50 & $0.65 \mathrm{M}$ & a & -0.007 & $0.5,1$ & $1.5 \mathrm{E}-5$ & Negative & None \\
\hline 50 & 0 & a & 0.209 & $0.7,0.8$ & $8.3 \mathrm{E}-6$ & Negative & None \\
\hline
\end{tabular}

* The first value for OCP, CR, and $\mathrm{i}_{\mathrm{P}}$ corresponds to the $95{ }^{\circ} \mathrm{C}$ test. 
The test conditions include the test temperature, the presence of sodium glycolate (GA), and the level of aggressive species. The parameters include the OCP at the conclusion of potential monitoring, the general corrosion rate calculated for the LPR test (CR in mils/year (mpy)), the current density at $200 \mathrm{mV}$ more electropositive than the OCP, and the state of the hysteresis (either positive or negative). For hysteresis, if one set of data showed a positive hysteresis and another set a negative or undefined hysteresis, the worst case is indicated in the table. A positive hysteresis is indicative of localized corrosion. An undefined hysteresis shows features of both positive and negative hystereses and is considered worse than a negative hysteresis which indicates no action of localized corrosion, especially pitting. The CPP scans in Figure 3-6 show examples of positive (cp9cC100C) and undefined (cp9cC103B) hystereses.

For C276 in Category 2 solutions near the boiling point, localized corrosion was either observed on the sample in the form of pitting or a positive hysteresis was seen in the CPP scan as shown by the data in Table 3-3. However, there was no consistent trend in the data that indicated the presence of the glycolate anion significantly lowers the corrosion resistance of C276 in simulated SRAT/SME supernates. The only consistent trend is that the presence of the glycolate anion shifted the corrosion potential to more electronegative or active values. This shift came with no overall change in the current density as measured by the $i_{p}$ value. The general corrosion rates were not different, but were more dependent on the level of aggressive species. .

The only condition which had distinguishable pits $(>1 \mu \mathrm{m})$ was with low aggressive species in the presence of the glycolate anion. 15- $\mu \mathrm{m}$ pit depths were measured at the conclusion of this tests. Figure 3-7 shows the post-test photographs of samples which represent the worst case with (A) and without (B) sodium glycolate.
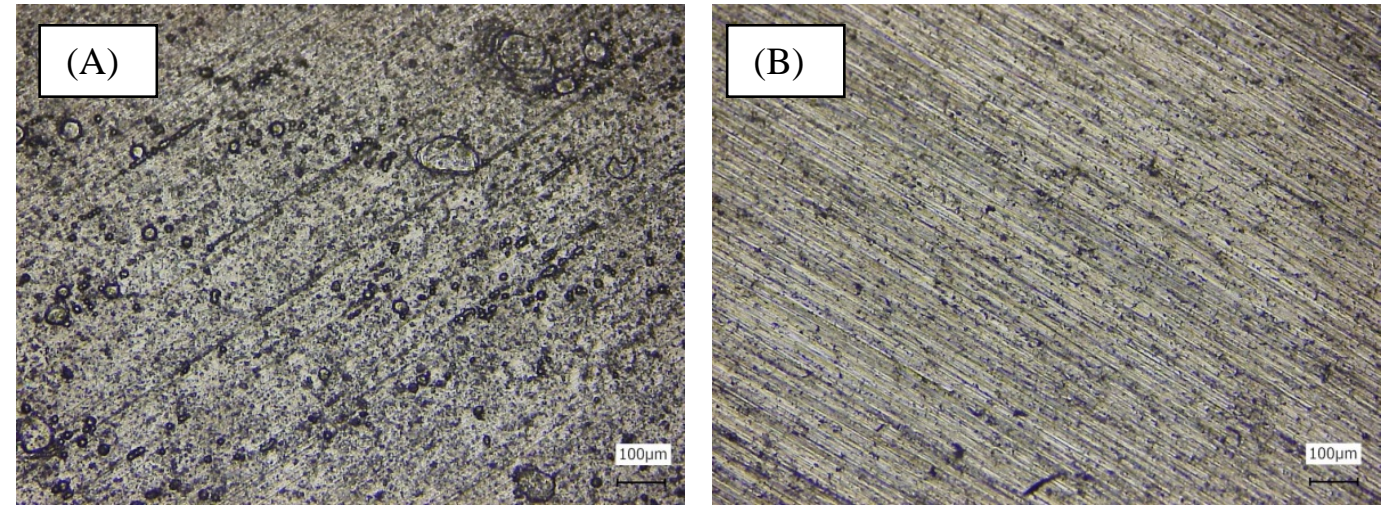

Figure 3-7 Post-test photographs of C276 in Category 2 solutions: (A) with sodium glycolate and low level of aggressive species (condition a); and (B) without sodium glycolate and low levels of iron and high levels of aggressive species (condition b)

At the lower temperature of $50{ }^{\circ} \mathrm{C}$, the electrochemical results showed a minimal effect of the glycolate anion with no difference in observed corrosion. The CPP scans showed a negative hysteresis with pristine samples at the end of testing both with and without sodium glycolate. Similar to the high temperature results, the OCP in glycolate-containing solutions was shifted to more electronegative potentials. These tests were performed with a low concentration of aggressive species.

The aggressive species concentration also impacted the corrosion resistance of C276 in the SRAT/SME supernate. The effect appeared to be similar both with and without the glycolate anion present. The data for glycolate-free solutions is more difficult to interpret due to the variability in the data as shown by the CPP scans in Figure 3-8 (A). 

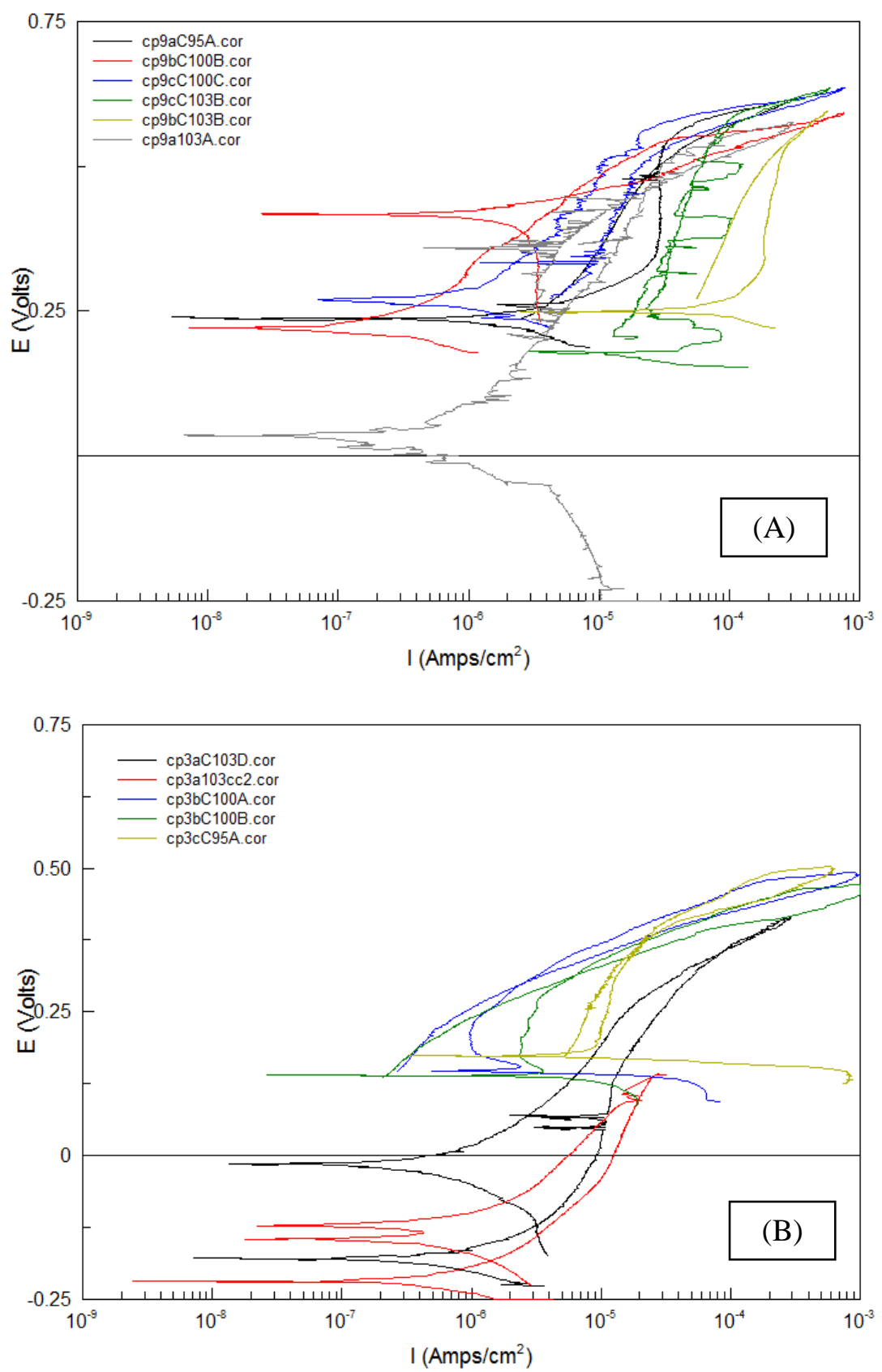

Figure 3-8 CPP scans for C276 in SRAT/SME supernate without (A) and with (B) sodium glycolate as a function of the concentrations of iron and aggressive species

Duplicate tests for each level of aggressive species in these solutions showed a wide difference in either the measured current density (i.e. large separation along the x-axis for conditions b and c) or the potential (i.e. large separation along the $y$-axis for condition a). The agreement between duplicate tests in glycolate-containing solutions was better as shown in Figure 3-8 (B). For both types of solutions, the OCP shifts to more electropositive values and the current density in the passive region is reduced with the higher levels of mercury and iron. These shifts are associated with the oxidizing nature of both mercury and iron. 
The general corrosion rates showed a slight correlation with aggressive species and iron concentration when the glycolate anion was present, increasing as both these concentrations increased. The results are similar to literature data for exposure to glycolic acid only [3]. For the glycolate-free solutions, there is sufficient overlap in the data that no change in corrosion rate can be associated with changes in the iron or aggressive species concentrations.

Ultimet and Stellite alloys had similar results (Table 3-4) to those observed for C276 in the presence of sodium glycolate. The CPP scans for Ultimet and Stellite are shown in Figure 3-9. Testing was performed for these alloys only with the glycolate anion present. The reproducibility of the data between duplicate tests was better for the Ultimet and Stellite alloys than for C276. This outcome was attributed to the C276 testing being performed ahead of most of the Ultimet and Stellite test, although not exclusively. The 304L alloy was used in place of 316L to get a conservative estimate of the impact of glycolate anion on the corrosion resistance of stainless steels.

At low concentrations of aggressive species and iron, Ultimet was passive with no indication of localized corrosion, whereas Stellite had some accelerated corrosion. In the presence of high concentrations of aggressive species both alloys were found to pit with a positive hysteresis. Pit depths for Ultimet increased from 10-20 $\mu \mathrm{m}$ to 30-50 $\mu \mathrm{m}$ at the high aggressive species concentration with a change from low to high iron concentration (condition b to c), respectively. Stellite pits depths were approximately 5$10 \mu \mathrm{m}$ in both these solutions.

Table 3-4 Electrochemical Parameters for Ultimet, Stellite, and 304L in Category 2 Solutions

\begin{tabular}{|l|c|l|c|c|c|c|c|l||}
\hline \hline Material & $\mathbf{T}\left({ }^{\circ} \mathbf{C}\right)$ & $\mathbf{G A}$ & $\begin{array}{c}\text { Aggressive } \\
\text { Species }\end{array}$ & $\begin{array}{c}\text { OCP } \\
\mathbf{( V )}\end{array}$ & $\begin{array}{c}\mathbf{C R} \\
(\mathbf{m p y})\end{array}$ & $\begin{array}{c}\mathbf{i}_{\mathbf{p}} \\
\left(\mathbf{A} / \mathbf{c m}^{2}\right)\end{array}$ & Hysteresis & Corrosion \\
\hline Ultimet & 90 & $0.65 \mathrm{M}$ & $\mathrm{a}$ & -0.088 & 0.45 & $2.41 \mathrm{E}-5$ & Negative & None \\
\hline & 100 & $0.65 \mathrm{M}$ & $\mathrm{b}$ & 0.142 & 1.8 & $7.7 \mathrm{E}-6$ & Positive & Pitted \\
\hline & 95 & $0.65 \mathrm{M}$ & $\mathrm{c}$ & 0.173 & 2.8 & $4.4 \mathrm{E}-6$ & Positive & Pitted \\
\hline Stellite & 100 & $0.65 \mathrm{M}$ & $\mathrm{a}$ & -0.143 & 0.5 & $5.5 \mathrm{E}-6$ & Undefined & Corroded \\
\hline & 100 & $0.65 \mathrm{M}$ & $\mathrm{b}$ & 0.148 & 24.3 & $1.5 \mathrm{E}-5$ & Positive & $\begin{array}{l}\text { Incipient } \\
\text { pits }\end{array}$ \\
\hline & 100 & $0.65 \mathrm{M}$ & $\mathrm{c}$ & 0.166 & 5 & $7.9 \mathrm{E}-6$ & Positive & Pitted \\
\hline 304L & 50 & $0.65 \mathrm{M}$ & $\mathrm{a}$ & -0.054 & 0.3 & $5.4 \mathrm{E}-6$ & Negative & None \\
\hline \hline
\end{tabular}

* a, low levels of $\mathrm{Cl}, \mathrm{SO}_{4}^{-2}$, and $\mathrm{Hg}$; b, low level of $\mathrm{Fe}$ and high levels of $\mathrm{Cl}, \mathrm{SO}_{4}{ }^{-2}$, and $\mathrm{Hg}$; c, high levels of Fe, $\mathrm{Cl}$, $\mathrm{SO}_{4}^{-2}$, and $\mathrm{Hg}$.

Similar to C276, at higher concentrations of aggressive species the OCP shifted to more electropositive values and lower current densities in the passive region of the CPP curve. The general corrosion rates were also found to be greater with the higher aggressive species and iron concentrations. These changes are associated with the oxidizing nature of mercury and iron as well as the presence of higher concentrations of chloride and sulfate.

The corrosion of 304L in the glycolate-containing solution was judged to be acceptable for service with low general corrosion rates and passivity as indicated by the CPP scans and the lack of any localized corrosion observed on the sample, unlike the $70 \%$ glycolic acid test where pitting was observed. The test solutions were heated to $50{ }^{\circ} \mathrm{C}$ and the chloride, sulfate and iron concentrations were low. 

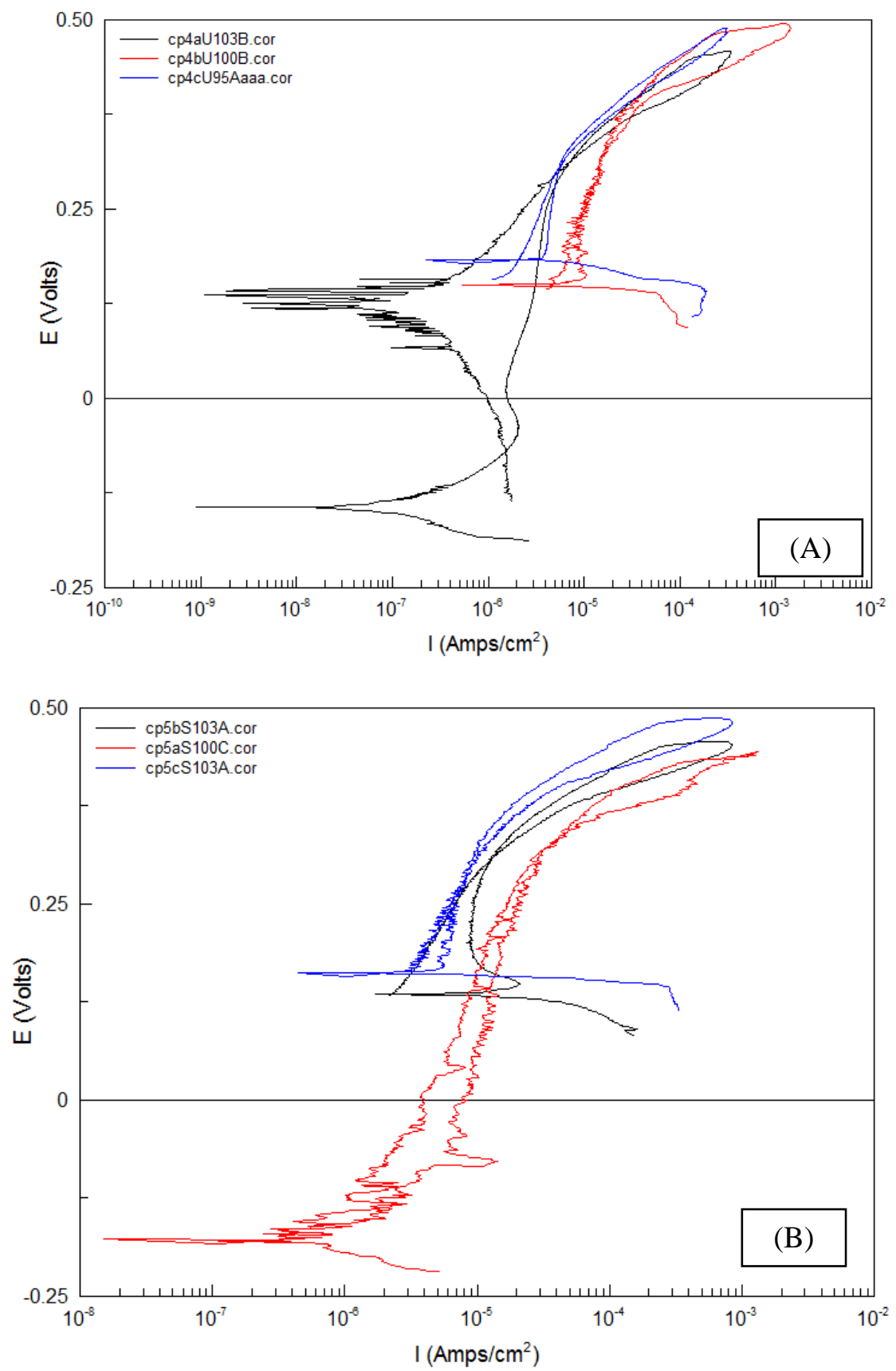

Figure 3-9 CPP scans for Ultimet (A) and Stellite (B) in SRAT/SME supernate with sodium glycolate as a function of the concentrations of iron and aggressive species

\subsubsection{Category 3 - SRAT/SME Condensate}

The SRAT/SME condensate is a combined stream from the SRAT/SME condenser as well as the mercury wash water tank, used to collect mercury from this waste stream. The materials of construction for the tanks in this system are 316L and 304L. These alloys did not show any adverse corrosion in the presence of sodium glycolate at $50{ }^{\circ} \mathrm{C}$, the maximum operating temperature for these vessels. The summary of the electrochemical parameters are given in Table 3-5 and the CPP scans are shown in Figure 3-10. The parameters include the OCP at the conclusion of potential monitoring, the general corrosion rate 
calculated for the LPR test, the current density at $200 \mathrm{mV}$ more electropositive than the OCP, and the hysteresis observed in the CPP scan. One sample of 304L in the solution with the glycolate anion present had a high corrosion rate of 5.6 mpy which shifted the average high. Otherwise all corrosion rates were at a low corrosion rate of approximately $1 \mathrm{mpy}$.

Table 3-5 Electrochemical Parameters for 316L and 304L in Category 3 Solutions

\begin{tabular}{|l|c|c|c|c|c|l|l||}
\hline Material & $\mathbf{T}\left({ }^{\circ} \mathbf{C}\right)$ & $\mathbf{G A}$ & $\begin{array}{c}\text { OCP } \\
(\mathbf{V})\end{array}$ & $\begin{array}{c}\mathbf{C R} \\
(\mathbf{m p y})\end{array}$ & $\begin{array}{c}\mathbf{i}_{\mathbf{p}} \\
\left(\mathbf{A} / \mathbf{c m}^{2}\right)\end{array}$ & Hysteresis & Corrosion \\
\hline 316L & 50 & $0.18 \mathrm{~g} / \mathrm{L}$ & 0.49 & 0.16 & $2.1 \mathrm{E}-6$ & Negative & None \\
\hline & 50 & 0 & 0.502 & 0.13 & $1.9 \mathrm{E}-6$ & Negative & None \\
\hline 304L & 50 & $6 \mathrm{~g} / \mathrm{L}$ & 0.45 & 2.9 & $8.4 \mathrm{E}-6$ & Negative & None \\
\hline \multicolumn{1}{|l}{} & 0 & 0.494 & 0.08 & $1.4 \mathrm{E}-6$ & Negative & None \\
\hline
\end{tabular}

There was no indication of localized corrosion as shown by the negative hysteresis of the CPP scans and the lack of corrosion attack observed on the samples after testing. From the CPP scans shown in Figure $3-10$, a change in the passive characteristics of the oxide occurs at about $0.8 \mathrm{~V}$ for both alloys, where the passive current density increases by an order of magnitude. This change is independent of the presence of the glycolate anion. The glycolate shifts the OCP to slightly more electronegative values similar to the results for C276 in the SRAT/SME supernate. The shift, however, is far less significant, which correlates with the lower mercury concentration in these solutions. The general corrosion rates are slightly greater with glycolate present, but the difference is not considered significant for the viability of these vessels and components.

In performing this set of test, the potential limit of $1.2 \mathrm{~V}$ was reached prior to the current limit of 1 $\mathrm{mA} / \mathrm{cm}^{2}$. These limits are set to prevent the test from determining the electrochemical response at extreme conditions. In many cases, the current limit is reached before the potential limit and the surface oxide undergoes sufficient oxidation for an indication of localized corrosion. In these tests less surface oxidation occurred which may not have fully tested susceptibility to localized corrosion, although the dilute concentration of the solution constituents was not expected to cause localized corrosion.

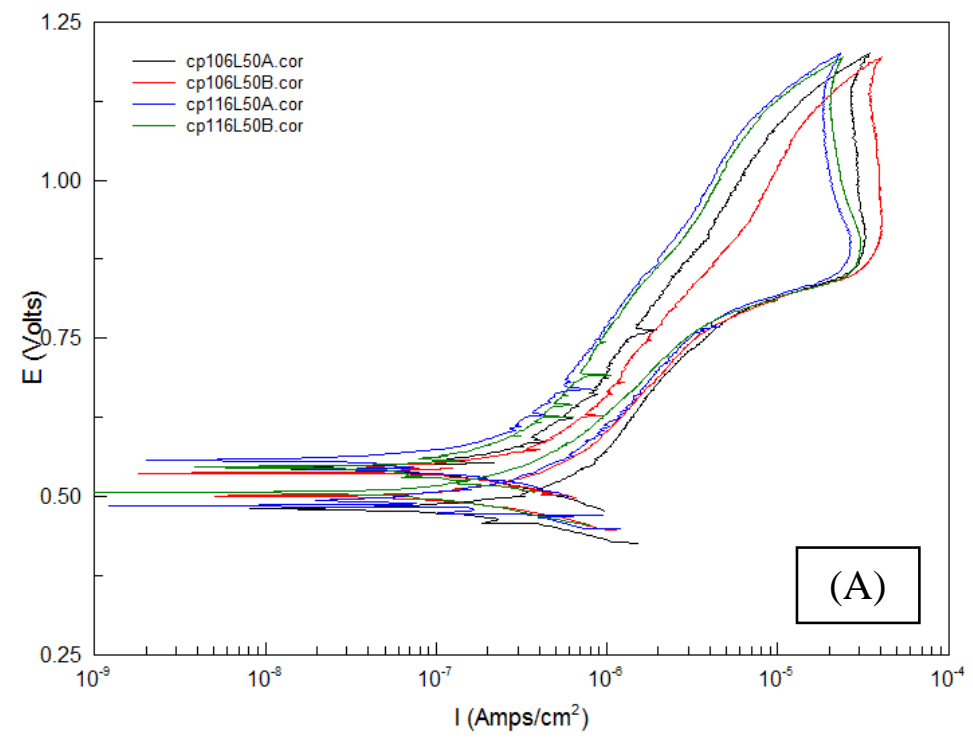

Figure 3-10 CPP scans for 316L (A) and 304L (B) in SRAT/SME condensate with (green and blue curves) and without (red and black curves) sodium glycolate at $50{ }^{\circ} \mathrm{C}$ 
SRNL-STI-2014-00281

Revision 0

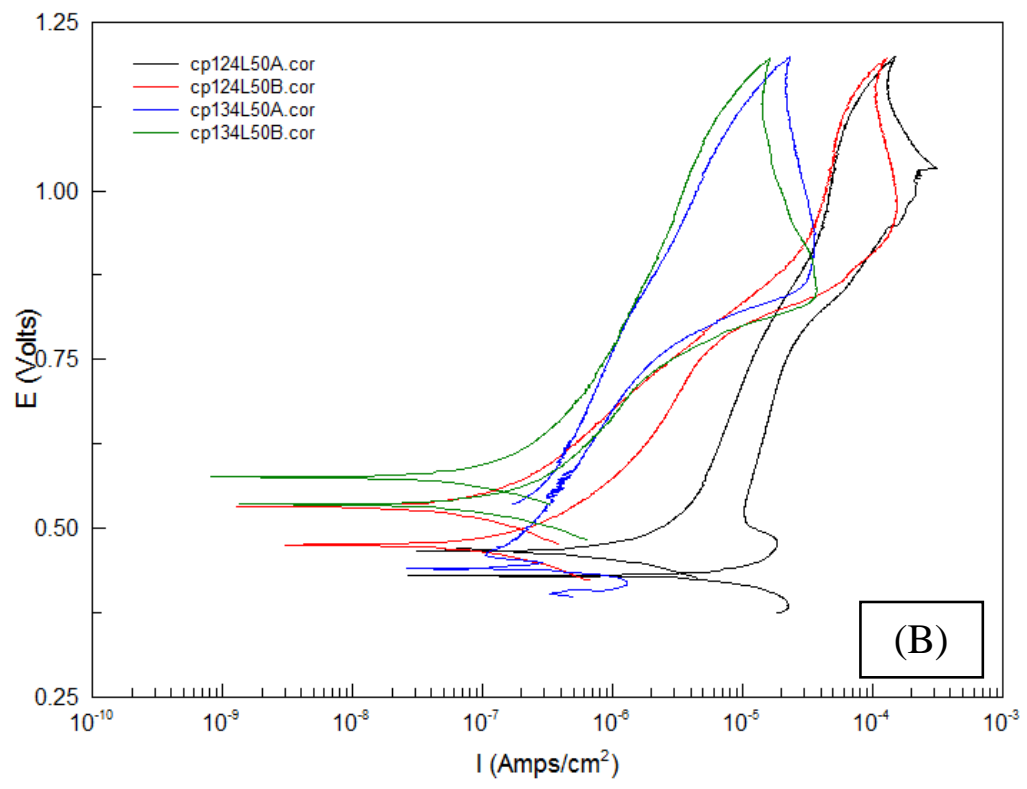

Figure 3-10 CPP scans for 316L (A) and 304L (B) in SRAT/SME condensate with (green and blue curves) and without (red and black curves) sodium glycolate at $50{ }^{\circ} \mathrm{C}$

\subsubsection{Category 4 - DWPF Acidic Recycle}

The acidic recycle was representative of solution chemistries sent back to the tank farm via the RCT so a range of solutions $\mathrm{pH}$ values were used to cover the acidic condensate from the melter off gas through the $\mathrm{pH}$ adjusted recycle ( $\mathrm{pH} 13)$ returning to the tank farm. Some tests initially planned for this simulant at low temperatures $\left(30^{\circ} \mathrm{C}\right)$ were not performed due to the low corrosion observed for the more severe conditions at high temperature $\left(100^{\circ} \mathrm{C}\right)$. Also the results for $304 \mathrm{~L}$ were taken as indicative of the results for 316L especially with the low corrosion rates. The electrochemical parameters for AllCorr, C276, 304L and A285 are shown in Table 3-6 for these Category 4 solutions.

Table 3-6 Electrochemical Parameters for AllCorr, C276, 304L and A285 in Category 4 Solutions

\begin{tabular}{|c|c|c|c|c|c|c|c|c|}
\hline Material & $\mathbf{T}\left({ }^{\circ} \mathrm{C}\right)$ & GA & $\mathbf{p H}^{*}$ & $\operatorname{OCP}(\mathrm{V})^{* *}$ & $\begin{array}{c}\text { CR } \\
(\mathrm{mpy})\end{array}$ & $i_{P}\left(A / \mathbf{c m}^{2}\right)$ & Hysteresis & Corrosion \\
\hline \multirow[t]{3}{*}{ AllCorr } & 100 & $10 \mathrm{~g} / \mathrm{L}$ & 1.9 & $0.339,0.418$ & 0.4 & $8.1 \mathrm{E}-6$ & Undefined & None \\
\hline & 30 & $10 \mathrm{~g} / \mathrm{L}$ & 1.5 & $0.219,0.34$ & $<0.1$ & $1.4 \mathrm{E}-6$ & Negative & None \\
\hline & 100 & $10 \mathrm{~g} / \mathrm{L}$ & 8.1 & $\begin{array}{c}-0.228,- \\
0.525 \\
\end{array}$ & 0.3 & 1.3E-6 & Positive & Small pits \\
\hline \multirow[t]{4}{*}{ C276 } & 100 & $10 \mathrm{~g} / \mathrm{L}$ & 1.6 & 0.208 & 2.7 & $3.7 \mathrm{E}-5$ & Negative & None \\
\hline & 100 & 0 & 1.5 & 0.171 & 0.6 & 7.7E-6 & Negative & None \\
\hline & 100 & $10 \mathrm{~g} / \mathrm{L}$ & 8 & -0.19 & 0.5 & $6.2 \mathrm{E}-6$ & Negative & None \\
\hline & 50 & $10 \mathrm{~g} / \mathrm{L}$ & 12.4 & 0.12 & 0.9 & $2.3 \mathrm{E}-5$ & Negative & None \\
\hline \multirow[t]{3}{*}{$304 \mathrm{~L}$} & 30 & $10 \mathrm{~g} / \mathrm{L}$ & 1.5 & 0.241 & $<0.1$ & $1.2 \mathrm{E}-6$ & Negative & None \\
\hline & 30 & 0 & 1.5 & 0.2 & $<0.1$ & 7.4E-7 & Negative & None \\
\hline & 30 & $10 \mathrm{~g} / \mathrm{L}$ & 7.7 & 0.038 & $<0.1$ & $9.8 \mathrm{E}-7$ & Positive & Tarnished \\
\hline \multirow[t]{2}{*}{ A285 } & 50 & $10 \mathrm{~g} / \mathrm{L}$ & 12.8 & -0.218 & $<0.1$ & 8.8E-7 & Negative & None \\
\hline & 50 & 0 & 13 & -0.217 & 0.1 & $1.1 \mathrm{E}-6$ & Negative & None \\
\hline
\end{tabular}

* The $\mathrm{pH}$ values were measured at the start of testing.

** Multiple OCP values are listed when a large difference existed between duplicate tests. 
AllCorr is the material of construction for the primary off-gas quencher. The condensate that forms in the quencher is expected to be acidic, but a neutral $\mathrm{pH}$ was also tested to determine if $\mathrm{pH}$ had an effect on the corrosion resistance in this area. The AllCorr OCP values were quite variable between samples as shown by the OCP values listed in Table 3-6, which differed from the other materials of constructions tested in the Category 4 solutions. The cause of this variability is unknown especially since the polarization characteristics were similar as shown by the CPP scans in Figure 3-11 for the $\mathrm{pH} 8.1$ simulant. At the acidic $\mathrm{pH}$, AllCorr did not show any indication of localized corrosion, but at the neutral $\mathrm{pH}$ a positive hysteresis was measured as shown in Figure 3-11.

The surface of the AllCorr samples after the testing in the $\mathrm{pH} 8.1$ simulant appeared to be pitted as shown by the photographs for sample 25Ac100A in Figure 3-12 (A). In Figure 3-12 (B), both pits (blue spots) and deposits (red spots) were observed on the surface in this height scan performed with a laser confocal microscope. Both these features had a z-direction measurement of $1 \mu \mathrm{m}$. EDS spectra of the deposits showed them to be principally an oxide of aluminum.

Although these CPP scans for the $8.1 \mathrm{pH}$ solution had a positive hysteresis, the pit protection potential, $\mathrm{E}_{\mathrm{pp}}$, was very electropositive at approximately $0.2 \mathrm{~V}$, SCE. $\mathrm{E}_{\mathrm{pp}}$ is the potential associated with a positive hysteresis when the reverse scan crosses the forward scan and below which pitting will not occur. In this simulant, the $E_{P P}$ is at a large potential difference from the OCP, ranging from 0.4 to $0.7 \mathrm{~V}$. Since this difference is greater than $0.2 \mathrm{~V}$ for the OCP, pitting is considered unlikely to occur in service [22]. There are a number of anodic to cathodic transitions on the reverse scan and the cathodic portion may be associated with the reduction of polyatomic ions in solution.

For C276, the presence of glycolate affected the measured corrosion response in these tests. The general corrosion rate was found to be higher ( $2.7 \mathrm{mpy}$ with glycolate versus $0.6 \mathrm{mpy}$ without), the OCP was more electropositive and $\mathrm{i}_{\mathrm{P}}$ was higher indicating a slightly less passive oxide for the 1.5 and 1.6 solutions. No localized corrosion was observed with or without the glycolate anion being present.

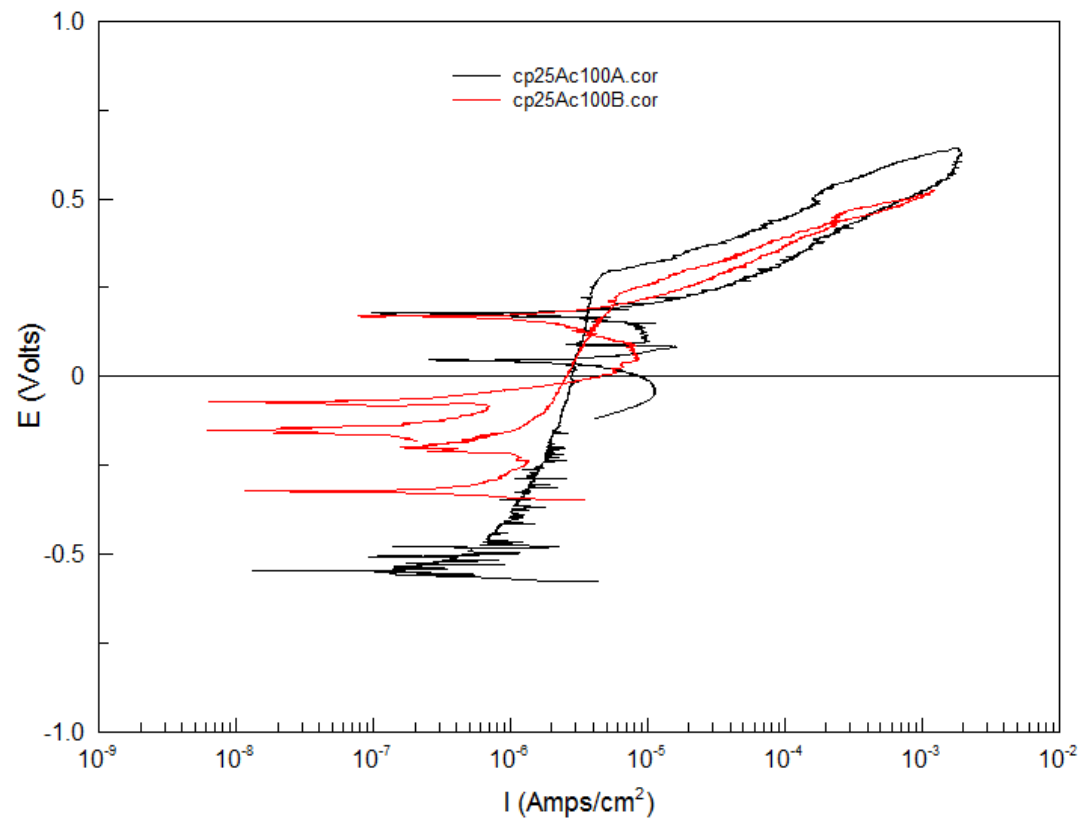

Figure 3-11 CPP scans for AllCorr in the DWPF recycle solution at $\mathrm{pH} 8.1$ with $10 \mathrm{~g} / \mathrm{L}$ sodium glycolate at $100^{\circ} \mathrm{C}$ 

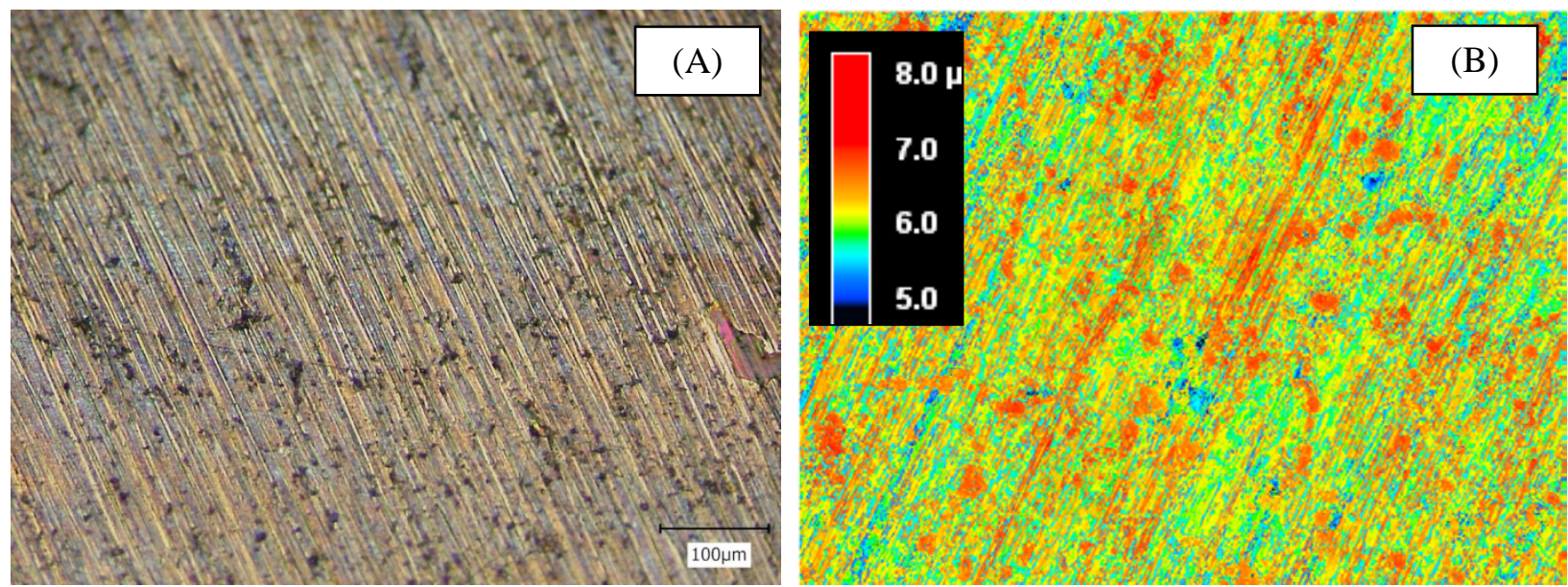

Figure 3-12

Surface analysis results of AllCorr sample 25Ac100A, which was tested in the DWPF recycle solution at $\mathrm{pH} 8.1$ with $10 \mathrm{~g} / \mathrm{L}$ sodium glycolate at $100{ }^{\circ} \mathrm{C}$ : (A) $10 \mathrm{X}$ photograph; and (B) height scan at 50x

The solution $\mathrm{pH}$ had a dramatic effect on the OCP shifting almost $400 \mathrm{mV}$ with change in $\mathrm{pH}$ from 1.5 to 8 at $100{ }^{\circ} \mathrm{C}$. The acidic solution was more oxidizing thereby sustaining the surface oxide on C276. For the $50{ }^{\circ} \mathrm{C}$ test at a $\mathrm{pH}$ of 12.4 , the OCP is similar to those measured in the acidic solutions. This shift is believed to be due to a buildup of hydroxide on the surface and not a substantial change in the surface oxide since the passive region is quite small and shows a similar transpassive potential as the $\mathrm{pH} 8$ solution results. These differences can be seen in the CPP scans shown in Figure 3-13.

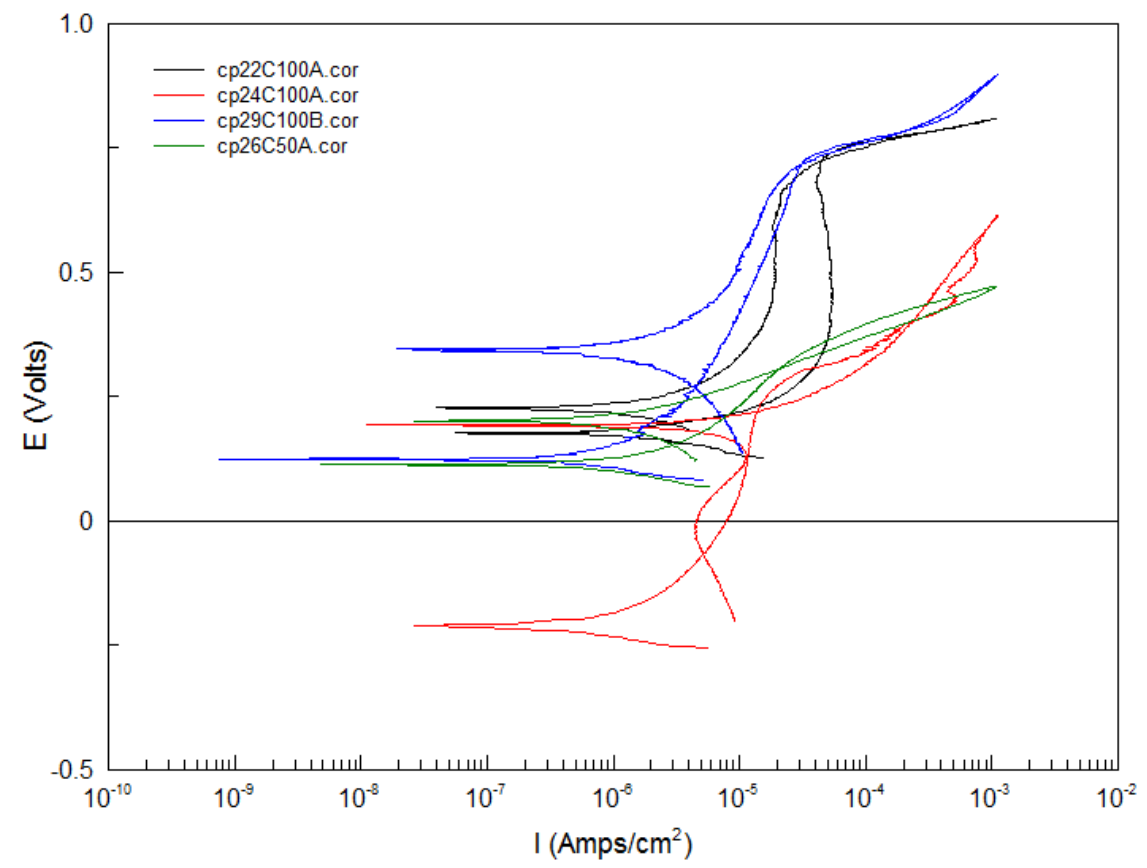

Figure 3-13 CPP scans for C276 in the pH 1.5 DWPF recycle solution with (10 g/L, cp22C100A) and without (CP29C100B) the glycolate anion, the $\mathrm{pH} 8$ solution with glycolate $(10 \mathrm{~g} / \mathrm{L}$, cp24C100A) at $100{ }^{\circ} \mathrm{C}$, and the $\mathrm{pH} 12.4$ solution at $50{ }^{\circ} \mathrm{C}$ with glycolate $(10 \mathrm{~g} / \mathrm{L}$, ср26C50A) 
Two tests were performed at $50{ }^{\circ} \mathrm{C}$, however, the second test was performed the day after. The potential shifted more electronegative by $450 \mathrm{mV}$. Changes in the solution chemistry may have caused such differences in potential so the second test was not used in the analysis.

For 304L, all the testing was conducted at $30^{\circ} \mathrm{C}$, so the general corrosion rates were low ( $\left.<0.1 \mathrm{mpy}\right)$. A small change in the corrosion behavior, as shown in Figure 3-14, was seen in the presence of the glycolate anion, similar to that for C276. The OCP shifted to more electropositive values and $i_{P}$ increased when sodium glycolate was in solution. In the $\mathrm{pH} 8$ solution, 304L showed indications of localized corrosion with a positive hysteresis and a pit protection potential of $0.25 \mathrm{~V}$, SCE (where reverse scan crosses the forward scan). Small pit like features as shown in Figure 3-15 were observed in the partially tarnished surface although there was not a measureable depth to them. These features may constitute incipient pits, especially in light of the positive hysteresis that occurred in the CPP scan. At a potential between 0.26 to $0.3 \mathrm{~V}$, an increase in the current density can be seen. This increase was associated with a change in the protective oxide and not a pit breakdown potential since pits of measureable depth were not observed and the surface was tarnished. The OCP shifted to more electronegative values with the change in $\mathrm{pH}$ similar to C276.

As shown by the data in Table 3-6, alloy A285, material of construction for Type IV $^{1}$, showed no significance difference in the corrosion rate or passive characteristics in the high $\mathrm{pH}$ simulant in the presence of the glycolate anion.

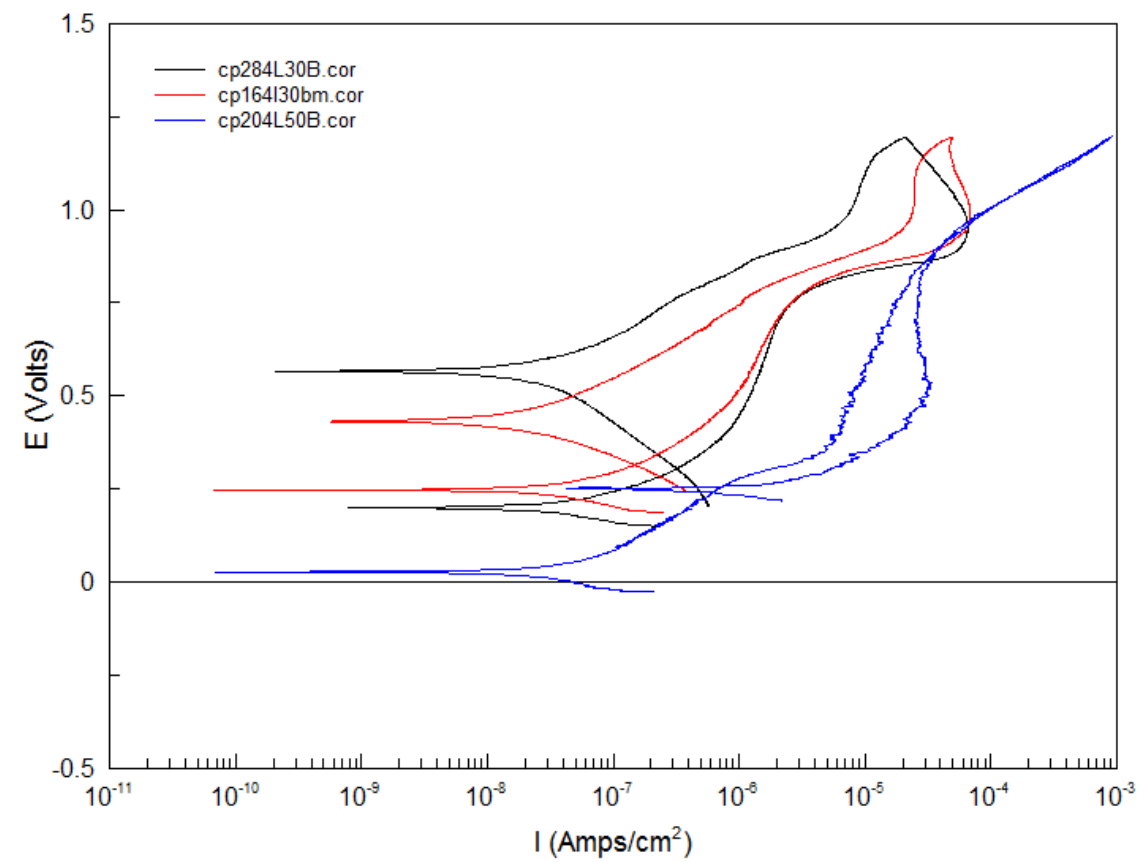

Figure 3-14 CPP scans for 304L in the pH 1.5 DWPF recycle solution with (10 g/L, cp164L30bm) and without (cp284L30B) the glycolate anion and the $\mathrm{pH} 8$ solution with glycolate (10 $\mathrm{g} / \mathrm{L}, \mathrm{cp} 204 \mathrm{~L} 50 \mathrm{~B})$ at $50^{\circ} \mathrm{C}$

\footnotetext{
${ }^{1}$ Tanks 22-25 actual material of construction is A212 carbon steel.
} 

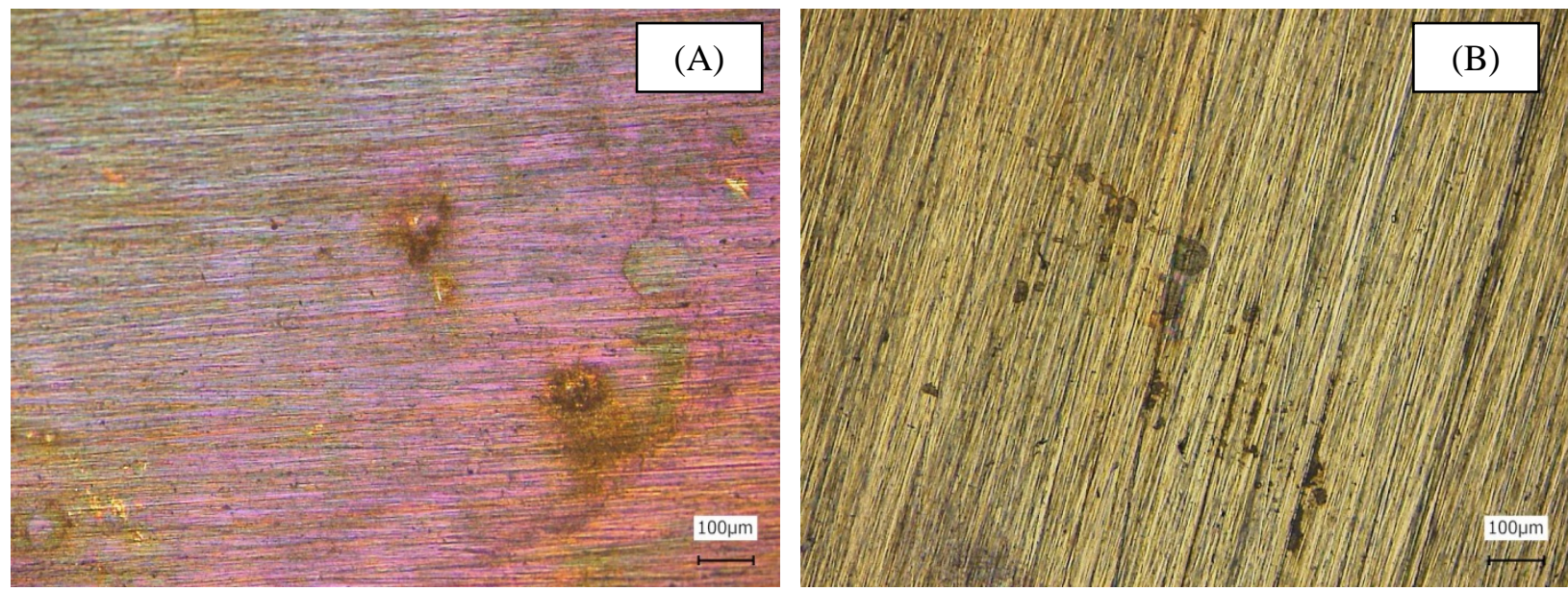

Figure 3-15 Photographs of two 304L samples tested in the pH 7.7 DWPF recycle solution with 10 $\mathrm{g} / \mathrm{L}$ sodium glycolate at $30^{\circ} \mathrm{C}$ : (A) 204L30A and (B) 204L30B

\subsubsection{Category 5 - Basic Recycle}

The Category 5 solutions were representative of waste chemistries that feed the $2 \mathrm{H}$ evaporators and were based on Tank 43 sample analyses. The materials of construction were those for the $2 \mathrm{H}$ evaporator, Type III waste tanks and transfer lines. The test simulants were principally a nitrate/nitrite/carbonate chemistry based on sodium salts. The complete chemistry can be found in Attachment 3 . The test simulants had pH values that ranged between 12.5 and 13 ; except for the $30{ }^{\circ} \mathrm{C}$ test with $304 \mathrm{~L}$ and $316 \mathrm{~L}$ samples. These tests were run at a $\mathrm{pH}$ around 11.5 . The solution $\mathrm{pH}$ dropped during the tests by approximately $0.4 \mathrm{pH}$ units. No significant change was noted in the solution during the testing.

This basic recycle chemistry was found to be compatible with the materials of construction in the presence or absence of the glycolate anion. The electrochemical parameters are shown in Table 3-7 for the alloys G30, 316L, 304L and A537 at the different temperatures and sodium glycolate concentrations.

Table 3-7 Electrochemical Parameters for G30, 316L, 304L and A537 in Category 5 Solutions

\begin{tabular}{||l|c|c|c|c|c|l|l||}
\hline Material & $\mathbf{T}\left({ }^{\circ} \mathbf{C}\right)$ & $\mathbf{G A}$ & $\begin{array}{c}\text { OCP } \\
(\mathbf{V})\end{array}$ & $\begin{array}{c}\mathbf{C R} \\
(\mathbf{m p y})\end{array}$ & $\begin{array}{c}\mathbf{i}_{\mathbf{p}} \\
\left(\mathbf{A} / \mathbf{c m}^{2}\right)\end{array}$ & Hysteresis & Corrosion \\
\hline G30 & 100 & $10 \mathrm{~g} / \mathrm{L}$ & -0.309 & 0.1 & $2.7 \mathrm{E}-5$ & Negative & None \\
\hline & 100 & 0 & -0.377 & $<0.1$ & $1.6 \mathrm{E}-6$ & Negative & None \\
\hline 316L & 30 & $10 \mathrm{~g} / \mathrm{L}$ & -0.224 & $<0.1$ & $6.8 \mathrm{E}-7$ & Negative & None \\
\hline & 100 & $10 \mathrm{~g} / \mathrm{L}$ & -0.204 & 0.3 & $1.4 \mathrm{E}-5$ & Negative & None \\
\hline 304L & 30 & $10 \mathrm{~g} / \mathrm{L}$ & -0.225 & $<0.1$ & $2.4 \mathrm{E}-6$ & Negative & None \\
\hline & 100 & $10 \mathrm{~g} / \mathrm{L}$ & -0.127 & 4 & $4.3 \mathrm{E}-5$ & Negative & None \\
\hline & 100 & 0 & -0.239 & 1.2 & $9.7 \mathrm{E}-6$ & Negative & None \\
\hline A537 & 30 & $10 \mathrm{~g} / \mathrm{L}$ & -0.29 & $<0.1$ & $2 \mathrm{E}-5$ & Negative & None \\
\hline & 100 & $10 \mathrm{~g} / \mathrm{L}$ & -0.311 & 0.6 & $5.8 \mathrm{E}-6$ & Positive & None \\
\hline & 100 & 0 & -0.327 & 0.2 & $2.5 \mathrm{E}-6$ & Positive & Corroded* \\
\hline
\end{tabular}

* The other sample had no corrosion 
When glycolate was present the $\mathrm{OCP}^{2}$ were generally more electropositive, $\mathrm{i}_{\mathrm{P}}$ were higher, and the general corrosion rate was slightly greater. Since the shift in potential and the corrosion rate differences were small, the effect of the glycolate anion on the materials of construction is not considered detrimental.

In this test simulant, G30 was passive with low $i_{P}$ as shown by the CPP scans in Figure 3-16. A change in the oxide passivity occurred with a passivation nose near $0 \mathrm{~V}(0.1$ to $0.15 \mathrm{~V}$ with glycolate, -0.01 to -0.04 $\mathrm{V}$ without glycolate). This passivation nose is less defined at $30^{\circ} \mathrm{C}$. The OCP and the CPP scans shifted to more electropositive potentials both with the presence of the glycolic anion and at lower temperatures. Lower temperatures shifted the curves to lower current densities indicating a less corrosive environment. In all tests, a negative hysteresis was found with no corrosion observed on the samples.

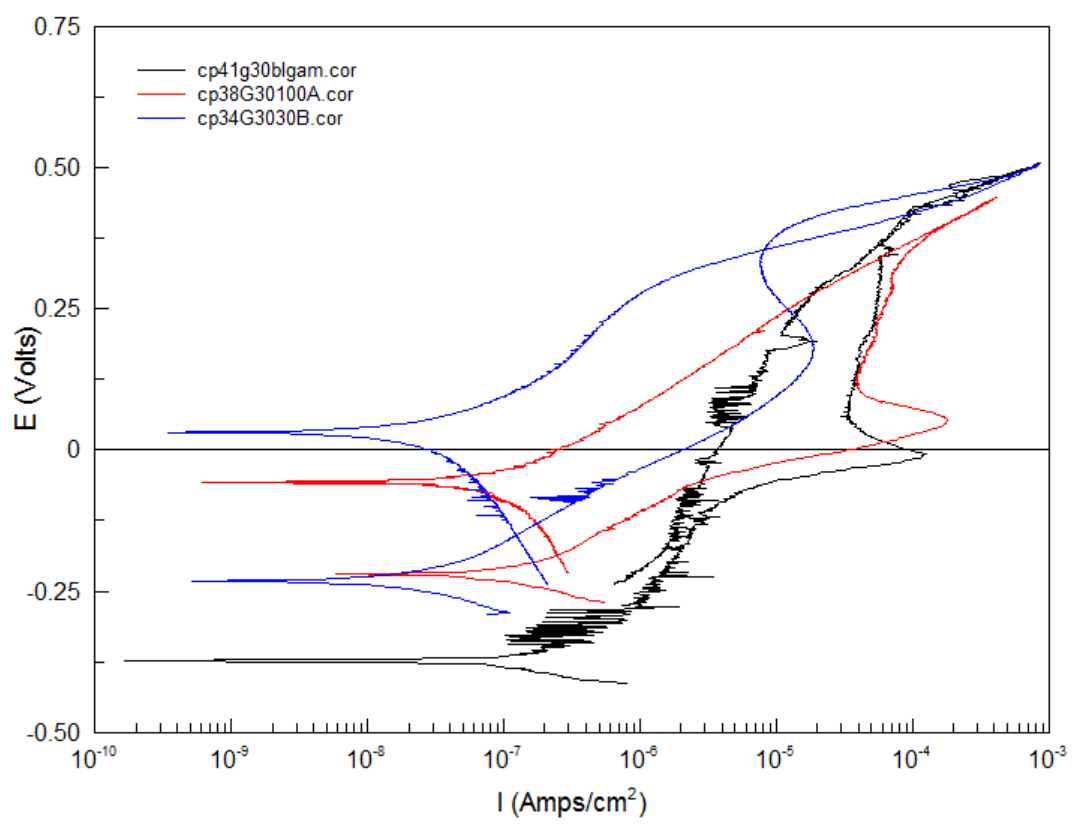

Figure 3-16 CPP scans for G30 in the basic recycle solutions with (10 g/L, cp38G30100A) and without (cp41G30blgam) the glycolate anion at $100{ }^{\circ} \mathrm{C}$ and at $30{ }^{\circ} \mathrm{C}$ with glycolate $(10$ g/L, cp34G3030B)

The results for 316L in this basic recycle simulant were similar to those for G30 as shown in Figure 3-17. A secondary passivation region was found to initiate near $0 \mathrm{~V}$. This secondary passivation region was more extended for G30 and at slightly lower current densities. The CPP scans shifted to more electropositive values and lower current densities at a lower temperature indicating a more passive environment.

The 304L samples showed the same basic passive characteristics as the G30 and 316L samples. One difference between 304L and the other two alloys was that at the lower temperature the OCP and the CPP scans did not shift to more electropositive values. When these tests were performed 316L and 304L samples were tested from the same batch of test simulant so batch difference is not a factor, although there are two other possibilities. The use of different samples for the 316L and G30 testing since only one 304L sample (labelled 304L \#1) was used for just about all the 304L testing in this simulant. Another factor is that both $316 \mathrm{~L}$ and G30 contain molybdenum which is known to increase the corrosion

\footnotetext{
${ }^{2}$ The OCP values at a set of test conditions for both G30 and 316L had large differences (0.1 V) between duplicates. Alloys 304L and A537 had good agreement between samples $(<0.05 \mathrm{~V})$.
} 
resistance in chloride bearing solutions. Similar to the other alloys the presence of the glycolate anion did shift the CPP scans to more electropositive values and slightly higher current densities.

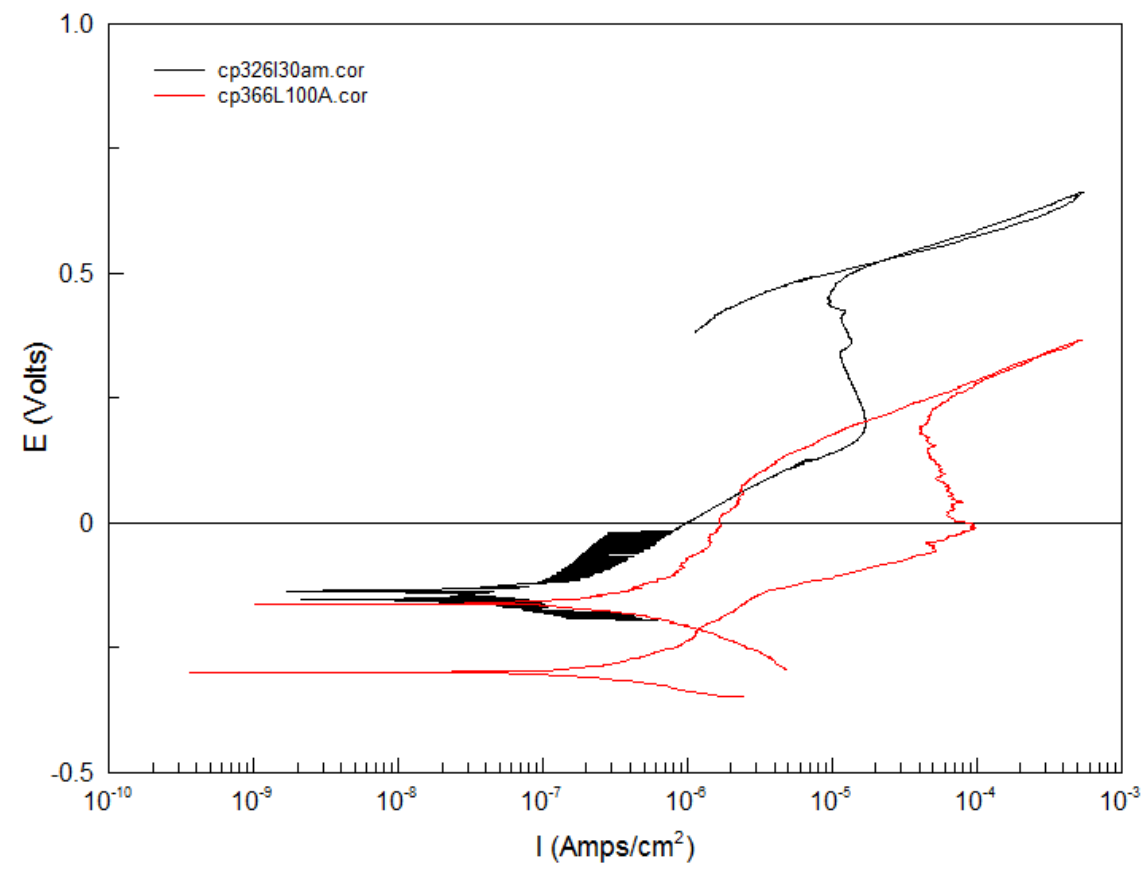

Figure 3-17 CPP scans for 316L in the basic recycle solutions with $10 \mathrm{~g} / \mathrm{L}$ sodium glycolate at $30{ }^{\circ} \mathrm{C}$ (cp326L30am) and at $100{ }^{\circ} \mathrm{C}(\mathrm{cp} 366 \mathrm{~L} 100 \mathrm{~A})$

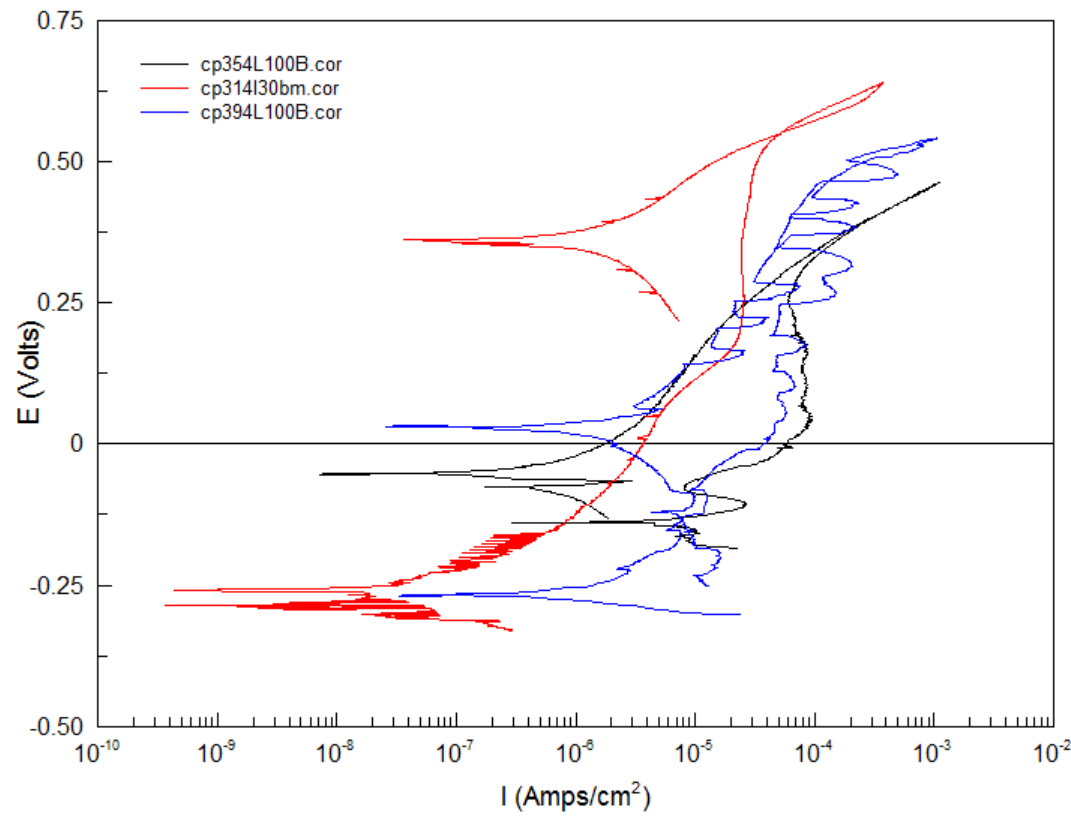

Figure 3-18 CPP scans for 304L in the basic recycle solutions with (10 g/L, cp354L100B) and without (cp394L100B) the glycolate anion at $100{ }^{\circ} \mathrm{C}$ and at $30{ }^{\circ} \mathrm{C}$ with glycolate $(10 \mathrm{~g} / \mathrm{L}$, cp314L30bm) 
The waste tank alloy A537 showed only small differences in the CPP scans in the basic recycle simulant as shown in Figure 3-19, which show scans at different temperatures and the presence of the glycolate anion. The CPP scan is a simple passive curve in this solution, which is at slightly lower current densities at $30^{\circ} \mathrm{C}$. The one sample without the glycolate anion at $100{ }^{\circ} \mathrm{C}$ that corroded was uniformly corroded across the surface

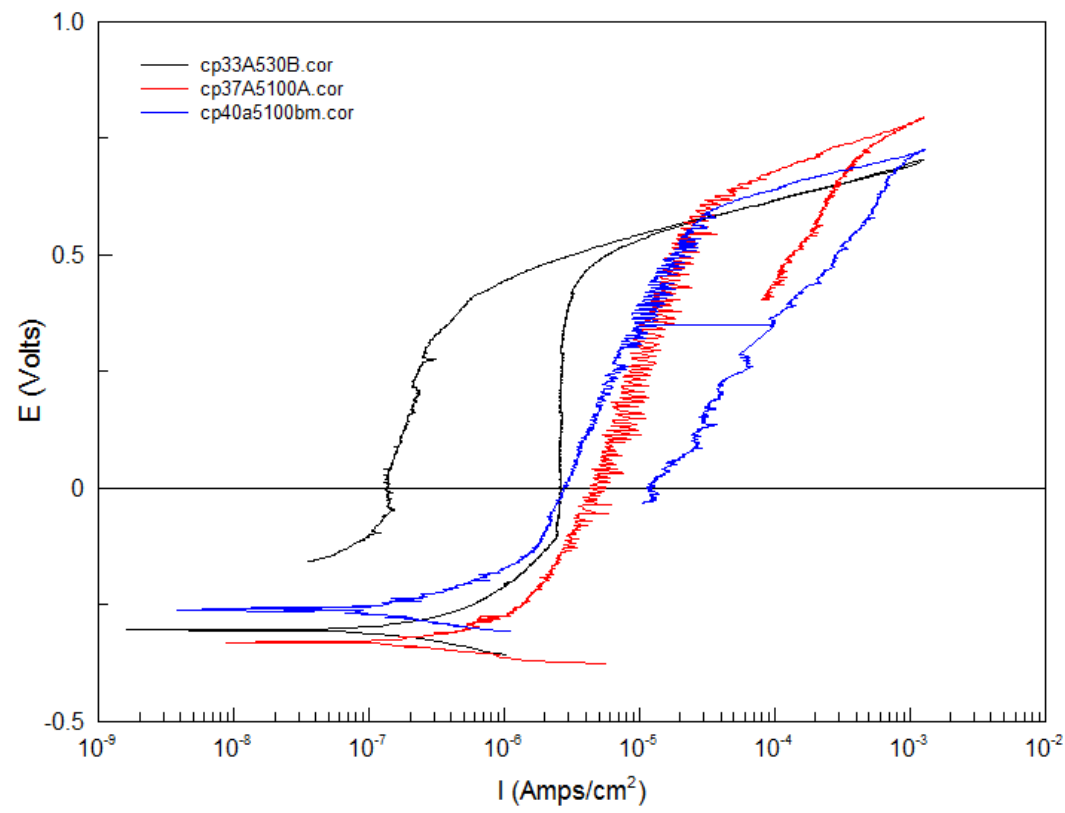

Figure 3-19 CPP scans for A537 in the basic recycle solutions with (10 g/L, cp37A5100A) and without (cp40A5100bm) the glycolate anion at $100{ }^{\circ} \mathrm{C}$ and at $30{ }^{\circ} \mathrm{C}$ with glycolate $(10$ g/L, cp33A530B)

The hysteresis differs as a function of temperature, being positive at $100{ }^{\circ} \mathrm{C}$. The $100{ }^{\circ} \mathrm{C}$ temperature did exceed the maximum temperature of $70{ }^{\circ} \mathrm{C}$ prescribed by the HLW tanks corrosion control program [54]. All reverse scans at $100{ }^{\circ} \mathrm{C}$ had noise (deleted from the scans shown in Figure 3-19). The one sample that corroded had noise at high current densities which may be associated with either the high corrosion of the sample in the particular solution or a testing error associated with a buildup of resistance between the reference electrode and sample. All other samples showed no corrosion. At $30{ }^{\circ} \mathrm{C}$, a negative hysteresis was found with no corrosion on the samples.

\subsubsection{Category 6 - Salt Processing}

The Category 6 solutions were representative of the waste feeding salt processing as well as low level waste feeding Saltstone, i.e. Tanks 49 and 50. The materials of construction included the processing vessels and piping of ARP and MCU, the components of Saltsone including the mixer, and Type III waste tanks and transfer lines. The test simulant was a nitrate/nitrite chemistry based on sodium salts. The complete chemistry can be found in Attachment 3. The test simulants had $\mathrm{pH}$ values that ranged between 12.6 and 13. The solution $\mathrm{pH}$ dropped only $0.2 \mathrm{pH}$ units at most during testing. No significant change was noted in the appearance of the solution during testing. All testing was conducted at $50{ }^{\circ} \mathrm{C}$.

The salt processing chemistry was found to be compatible with the materials of construction in the presence or absence of the glycolate anion as shown by the data in Table 3-8. Astralloy was the only material tested both with and without the glycolate anion. The other materials of construction had been 
tested under both glycolate conditions for Category 5 solutions, which was similar in chemistry. The glycolate anion was found not to be detrimental to the overall corrosion. The alloys all had low general corrosion rates (1 mpy or less) and passive CPP scans. The stainless steel alloys (304L and 316L) both displayed a secondary passive region (Figure 3-20), while the carbon steel alloys (A537 and Astralloy) had simple passive curves (Figure 3-21). For A537, the glycolic acid may be inhibitive since in previous testing with a similar solution without the glycolate anion, the material was susceptible to localized corrosion at a slightly higher nitrate concentration [53]. As expected the higher alloys had lower general corrosion rates and lower $i_{p}$. Testing that was originally planned for $30^{\circ} \mathrm{C}$ but was not completed due to the passive nature and low general corrosion rates observed at $50{ }^{\circ} \mathrm{C}$.

The alloys generally showed no susceptibility to localized corrosion with negative hystereses and samples with minimal surface degradation. One test with Astralloy in the salt processing simulant without the glycolate anion showed a positive hysteresis. The sample, however, looked as if it was freshly prepared for testing with no apparent surface degradation.

Table 3-8 Electrochemical Parameters for 316L, 304L, A537, and Astralloy in Category 6 Solutions

\begin{tabular}{||l|c|c|c|c|l|l||}
\hline Material & GA & $\begin{array}{c}\text { OCP } \\
(\mathbf{V})\end{array}$ & $\begin{array}{c}\text { CR } \\
(\mathbf{m p y})\end{array}$ & $\begin{array}{c}\mathbf{i}_{\mathbf{p}} \\
\left(\mathbf{A} / \mathbf{c m}^{2}\right)\end{array}$ & Hysteresis & Corrosion \\
\hline Astralloy & $10 \mathrm{~g} / \mathrm{L}$ & -0.296 & 0.5 & $7.2 \mathrm{E}-6$ & Negative & None \\
\hline & 0 & -0.217 & 0.7 & $3.4 \mathrm{E}-6$ & Positive* & None \\
\hline 316L & $10 \mathrm{~g} / \mathrm{L}$ & -0.239 & $<0.1$ & $4.4 \mathrm{E}-6$ & Negative & None \\
\hline 304L & $10 \mathrm{~g} / \mathrm{L}$ & -0.226 & $<0.1$ & $8.3 \mathrm{E}-6$ & Negative & None \\
\hline A537 & $10 \mathrm{~g} / \mathrm{L}$ & -0.294 & 1.1 & $9.3 \mathrm{E}-6$ & Negative & None \\
\hline
\end{tabular}

* The other sample had negative hysteresis

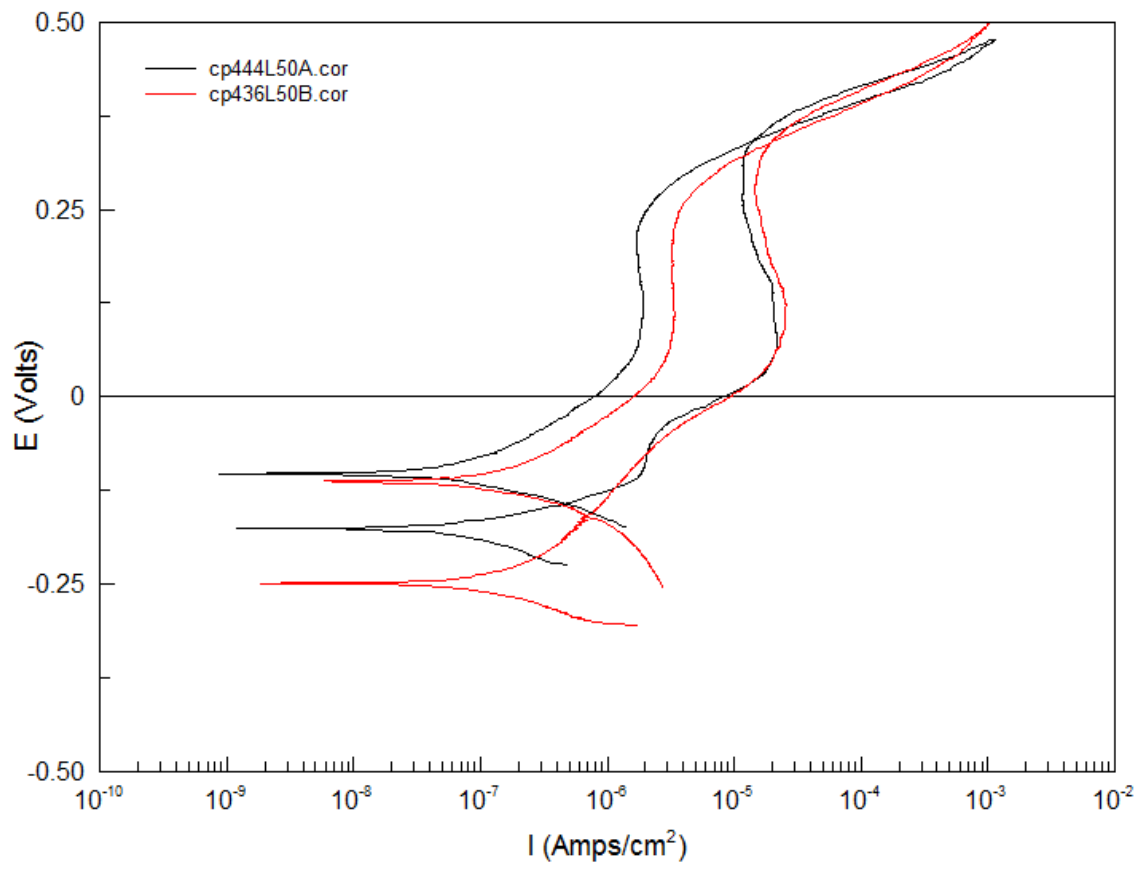

Figure 3-20 CPP scans for 304L (cp444L50A) and 316L (cp436L50B) in the salt processing solutions with $10 \mathrm{~g} / \mathrm{L}$ sodium glycolate at $50{ }^{\circ} \mathrm{C}$ 


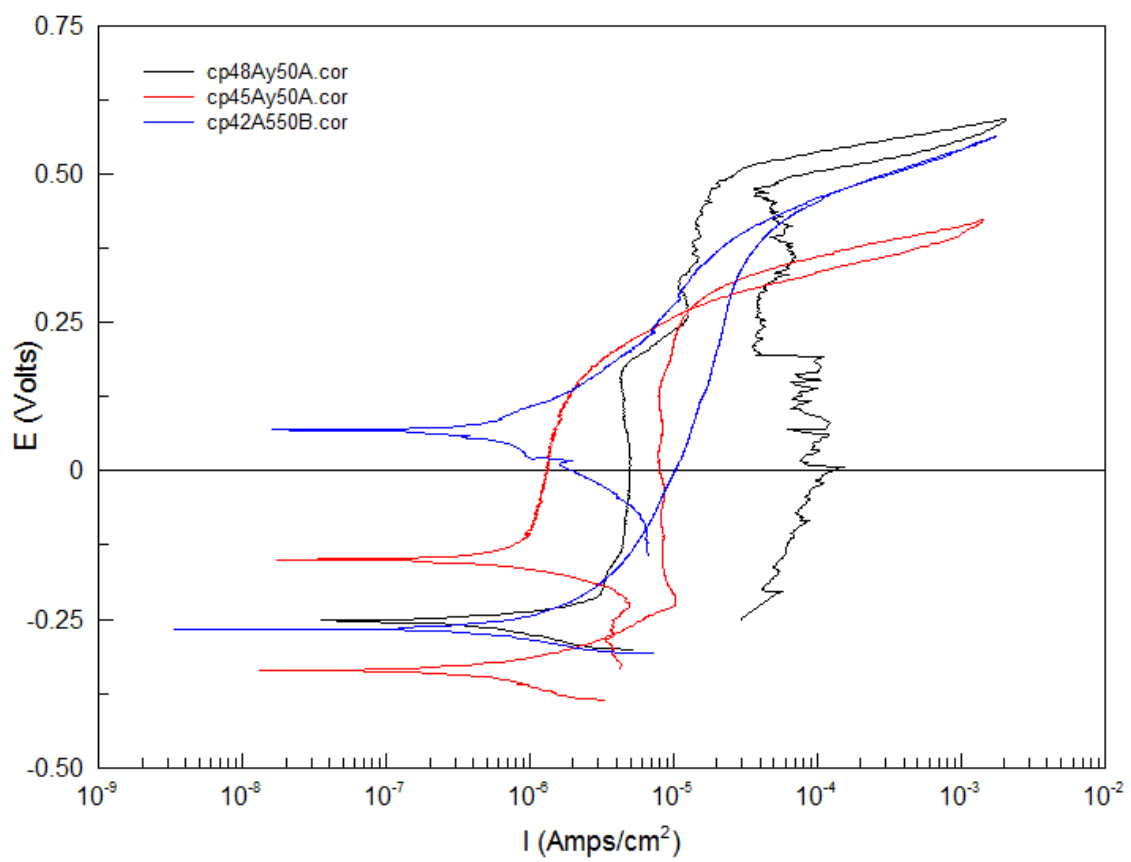

Figure 3-21 CPP scans for A537 (cp42A550B) and Astralloy (cp45Ay50A) in the salt processing solutions with $10 \mathrm{~g} / \mathrm{L}$ sodium glycolate and Astralloy (cp48Ay50A) with no glycolate anion at $50{ }^{\circ} \mathrm{C}$

\subsubsection{Category 7 - Boric Acid}

The Category 7 testing was specific to the MCU strip contactors for removal of cesium from the solvent used on the waste supernate. The solution in this contactor is $10 \mathrm{mM}$ boric acid. Testing was conducted at $50{ }^{\circ} \mathrm{C}$, the design maximum. These contactors are fabricated from 316L. The solutions $\mathrm{pH}$ was 6.4 when the glycolate anion was present and 5.7 without the glycolate anion. The $\mathrm{pH}$ increased by 0.6 and 1.4 when the glycolate anion was present or absent, respectively. The difference in the $\mathrm{pH}$ shift with the glycolate anion was an indication of its buffering capacity.

The boric acid solution was found to be compatible with 316L when the glycolate anion was present or absent from the test solution. The glycolate anion had a small effect on the corrosion potential, shifting to more electronegative values with glycolate, and $i_{p}$, shifting to higher current density with glycolate as shown by the data in Table 3-9. 316L showed only passivity with negative hystereses in these solutions as shown by the CPP scans in Figure 3-22.

Table 3-9 Electrochemical Parameters for 316L in Category 7 Solutions

\begin{tabular}{|l|c|c|c|c|c|l|}
\hline \hline Material & GA & $\begin{array}{c}\text { OCP } \\
(\mathbf{V})\end{array}$ & $\begin{array}{c}\text { CR } \\
(\mathbf{m p y})\end{array}$ & $\begin{array}{c}\mathbf{i}_{\mathbf{P}} \\
\left(\mathbf{A} / \mathbf{c m}^{2}\right)\end{array}$ & Hysteresis & Corrosion \\
\hline $316 \mathrm{~L}$ & $10 \mathrm{~g} / \mathrm{L}$ & -0.151 & $<0.1$ & $5.6 \mathrm{E}-7$ & Negative & None \\
\hline & $0 \mathrm{~g} / \mathrm{L}$ & -0.048 & $<0.1$ & $4.4 \mathrm{E}-7$ & Negative & None \\
\hline
\end{tabular}




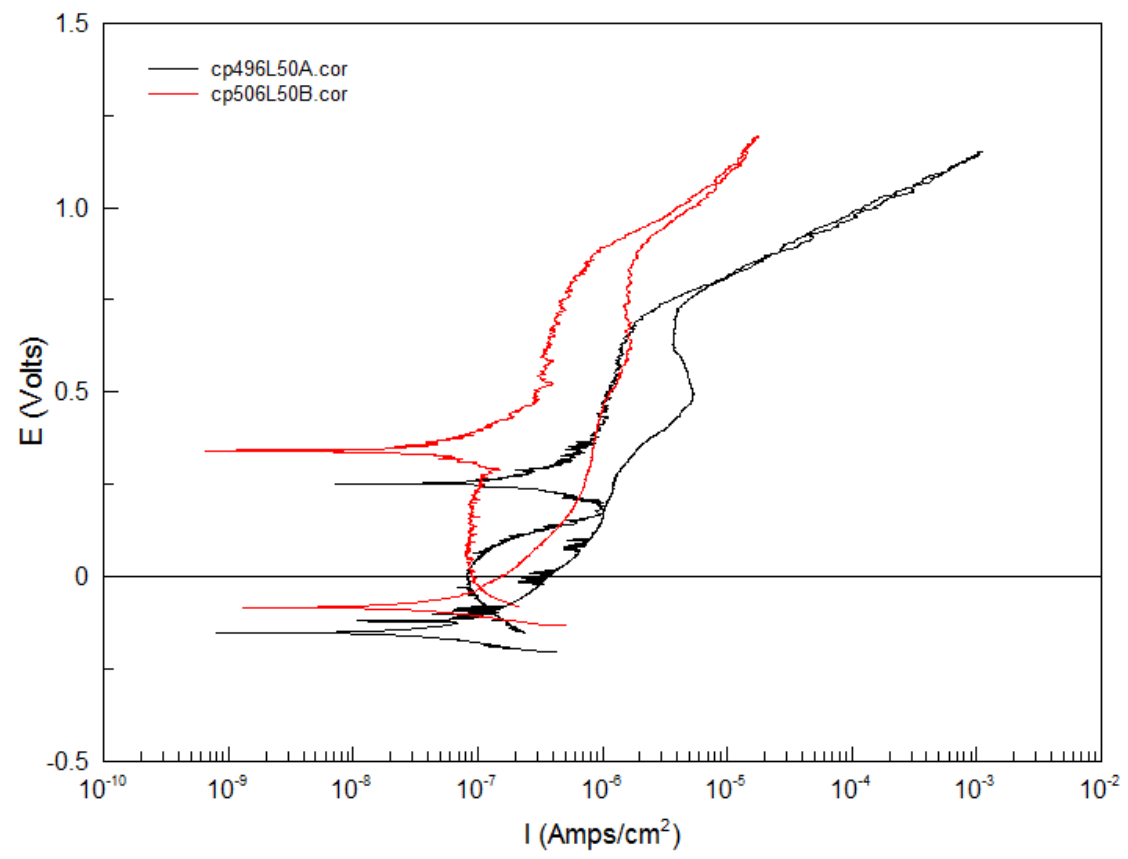

Figure 3-22 CPP scans for 316L in $10 \mathrm{mM}$ boric acid with (cp496L50A) and without (cp506L50B) 10 g/L sodium glycolate at $50^{\circ} \mathrm{C}$

\subsubsection{Category 8 - Dilute Waste}

The Category 8 solutions were representative of dilute waste streams especially the $2 \mathrm{H}$ condensate tank and piping and the ETF evaporator system tanks and piping. Only a small amount of glycolate is expected to be in these dilute streams. The materials of construction that were tested included 304L, A537, and G3. The testing with 304L was used as a conservative surrogate material for components made from 316L. The test simulants were principally a dilute nitrate chemistry based on salts with multiple cations. The complete chemistry can be found in Attachment 3. Target solutions $\mathrm{pH}$ values were 3, 6 (5 for G3), and 12. Actual $\mathrm{pH}$ values can be seen in Table 3-10 along with the electrochemical parameters from this testing. The solution $\mathrm{pH}$ dropped for alkaline solutions by up to $0.5 \mathrm{pH}$ units and was increased by 2-3 pH units for neutral solutions and minimal increases for acidic solutions. No significant change was noted in the solution appearance during testing.

In this dilute chemistry, G3 and 304L showed passive behavior in the presence or absence of the glycolate anion without indications of localized corrosion. A537, however, was susceptible to localized corrosion in alkaline solutions and general corrosion in neutral solutions in the presence or absence of the glycolate anion. The electrochemical parameters are shown in Table 3-10 for the alloys G3, 304L and A537 at the different temperatures and sodium glycolate concentrations. When glycolate was present the OCP were generally more electronegative, $i_{P}$ were higher, and the general corrosion rate was slightly greater. Since the shift in potential and the corrosion rate differences were small, the effect of the glycolate anion on the materials of construction is not expected to be detrimental over the life of the components.

The G3 alloy had passive behavior with a passivation nose at approximately $0.28 \mathrm{~V}$. This passivation nose was absent in glycolate-free solutions although a step is clearly seen near this potential as shown by the data given in Figure 3-23. Changes in the passivation current density at electropositive potentials well displaced from the OCP $(>0.2 \mathrm{~V})$ have been observed also in other test solution (i.e. basic recycle and SRAT/SME condensate). The passive oxide at these electropositive potentials is not as protective (i.e. higher current density). With the glycolate anion present, the current densities are even slightly higher. 
In the testing without the glycolate anion, both G3 samples were bronze in appearance at test completion, although it is not clear if this is associated with the the step change in the current density shown in Figure $3-23$.

Table 3-10 Electrochemical Parameters for G3, 304L, and A537 in Category 8 Solutions

\begin{tabular}{|l|c|c|c|c|c|c|l|l||}
\hline \hline Material & $\begin{array}{c}\mathbf{T} \\
\left({ }^{\circ} \mathbf{C}\right)\end{array}$ & $\begin{array}{c}\text { GA } \\
(\mathbf{g} / \mathbf{L})\end{array}$ & $\mathbf{p H}^{*}$ & $\mathbf{O C P}(\mathbf{V})$ & $\begin{array}{c}\mathbf{C R} \\
(\mathbf{m p y})\end{array}$ & $\begin{array}{c}\mathbf{i}_{\mathbf{p}} \\
\left(\mathbf{A} / \mathbf{c m}^{2}\right)\end{array}$ & Hysteresis & \multicolumn{1}{|c||}{ Corrosion } \\
\hline G3 & 107 & 0.033 & 5.2 & -0.1 & $<0.1$ & $1.3 \mathrm{E}-6$ & Negative & None \\
\hline & & 0 & 4.5 & 0.044 & $<0.1$ & $4.4 \mathrm{E}-7$ & Negative & None** \\
\hline 304L & 95 & 0.033 & 3.1 & 0.196 & 0.5 & $3.4 \mathrm{E}-6$ & Undefined & None \\
\hline & 95 & 0 & 3 & 0.228 & 0.1 & $1.8 \mathrm{E}-6$ & Undefined & None \\
\hline & 95 & 0.033 & 12 & -0.192 & 0.2 & $1.2 \mathrm{E}-6$ & Negative & None \\
\hline & 95 & 0 & 12 & -0.167 & $<0.1$ & $9.1 \mathrm{E}-7$ & Negative & None \\
\hline & 30 & 0.033 & 11.6 & -0.168 & $<0.1$ & $1.5 \mathrm{E}-6$ & Negative & None \\
\hline A537 & 30 & 0.033 & 5.4 & 0.243 & 0.6 & $7 \mathrm{E}-7$ & Negative & None \\
\hline & 95 & 0.033 & 12 & -0.109 & 1.5 & $1.7 \mathrm{E}-5$ & Positive & Pitted/Corroded \\
\hline & 95 & 0 & 12.1 & -0.139 & 1.3 & $5 \mathrm{E}-5$ & Positive & Pitted/Corroded \\
\hline & 30 & 0.033 & 11.6 & -0.122 & 0.3 & $1.8 \mathrm{E}-6$ & Positive & Pitted/Corroded \\
\hline
\end{tabular}

* As measured at the start of testing

** Both samples had a bronze color

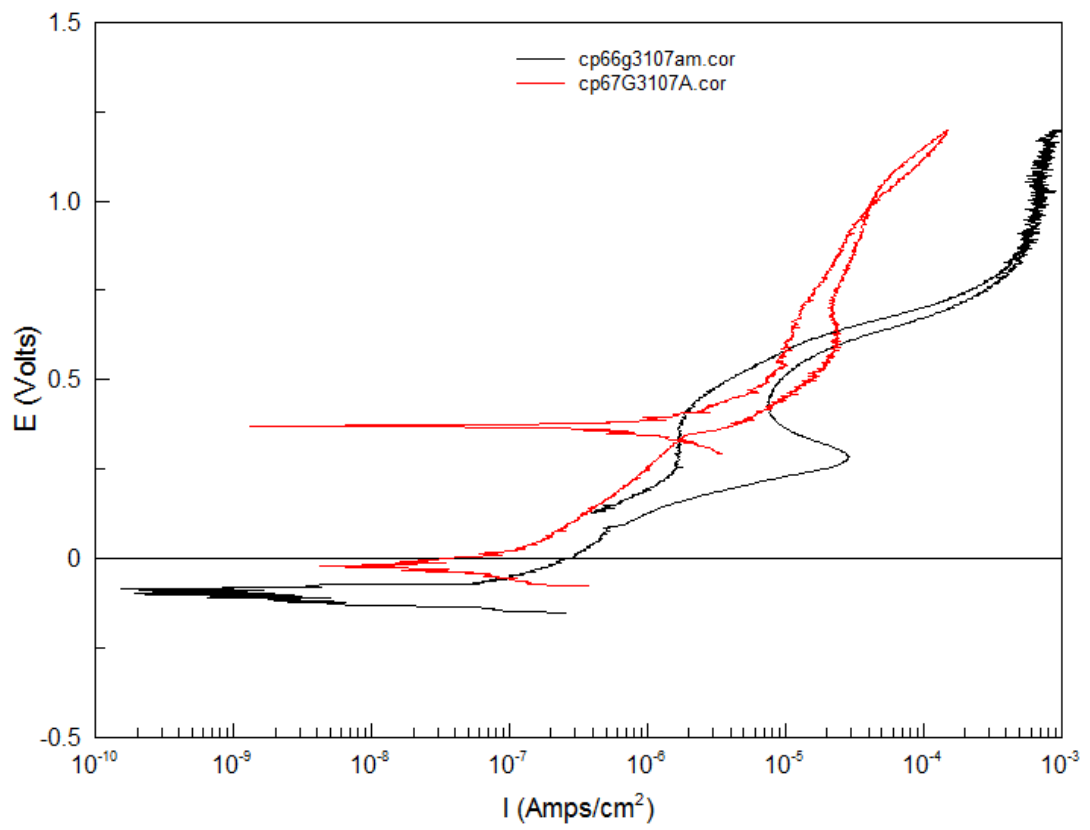

Figure 3-23 CPP scans for G3 in a dilute waste chemistry with (cp66G3107A) and without (cp67G3107A) $0.033 \mathrm{~g} / \mathrm{L}$ sodium glycolate at $107^{\circ} \mathrm{C}$

Similar to G3, 304L showed generally passive behavior. In the low $\mathrm{pH}$ solution, the hysteresis was not clearly negative or positive as shown by the CPP scans given in Figure 3-24. The reverse scans start as positive, but cross over at high electropositive potentials (0.85-0.9 V) and are at lower current densities for the remainder of the scan (i.e. negative hysteresis). Although the hysteresis was labeled as undefined, 
the samples did not show any localized corrosion and appeared almost as freshly polished. For 304L in this acidic solution two passivation noses were note at 0.3 and $0.7 \mathrm{~V}$.

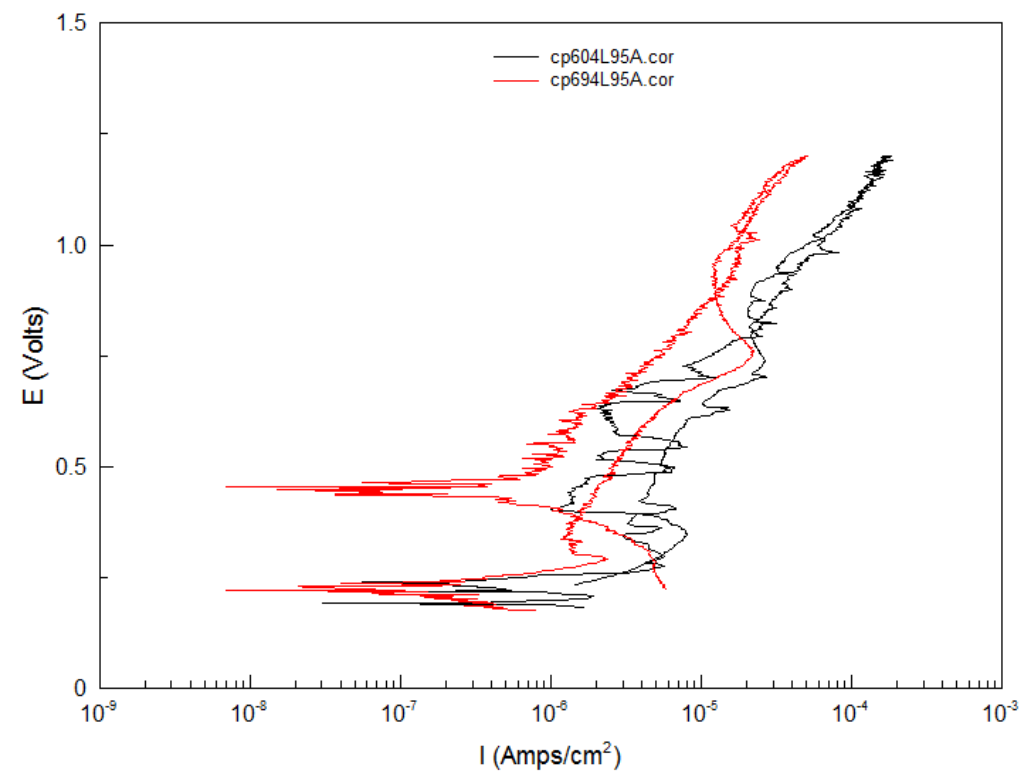

Figure 3-24 CPP scans for 304L in a dilute waste chemistry with (cp604L95A) and without (cp694L95A) $0.033 \mathrm{~g} / \mathrm{L}$ sodium glycolate at a $\mathrm{pH}$ 3and $107^{\circ} \mathrm{C}$

For the $\mathrm{pH} 12$ test solutions, the electrochemical nature of the solution shifted to more electronegative potentials because of the increase in hydroxide concentration. The corrosion behavior is still passive with a passivation nose at approximately $0.2 \mathrm{~V}$ as can be seen in Figure 3-25. The effects of temperature and the absence of the glycolate anion had a minimal effect.

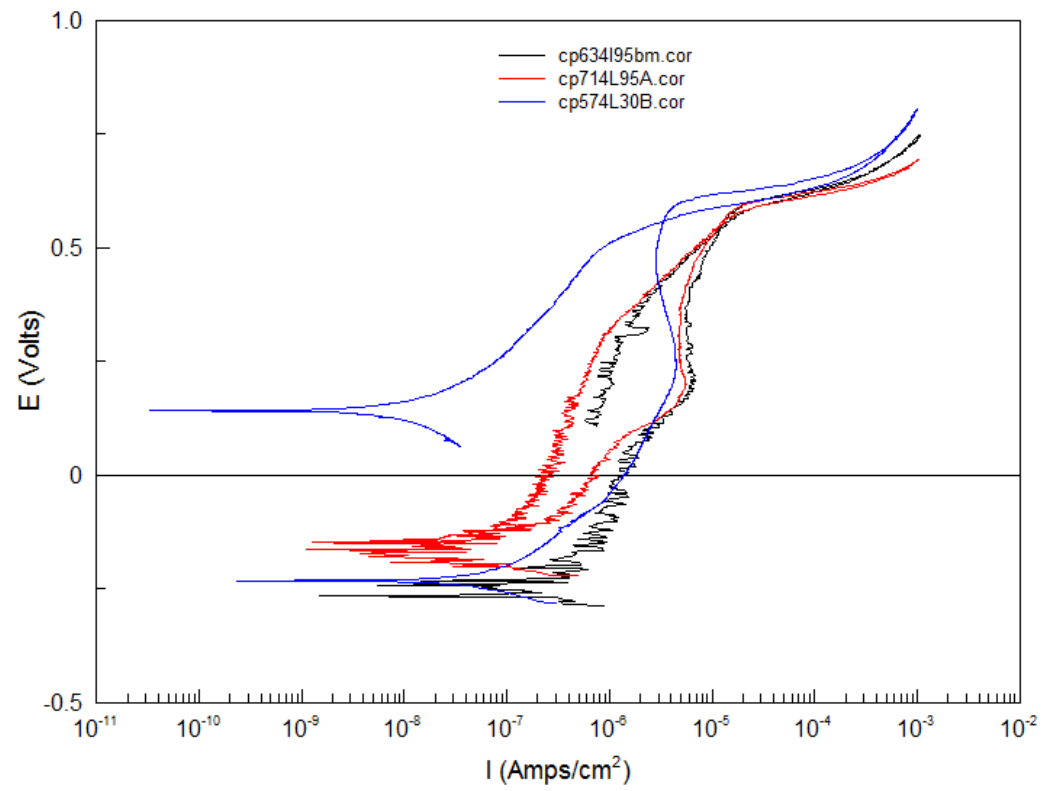

Figure 3-25 CPP scans for 304L in a dilute, $\mathrm{pH} 12$ waste chemistry with (cp634L95B) and without (cp714L95A) $0.033 \mathrm{~g} / \mathrm{L}$ sodium glycolate at $95{ }^{\circ} \mathrm{C}$ and with (cp574L30B) $0.033 \mathrm{~g} / \mathrm{L}$ sodium glycolate at $30{ }^{\circ} \mathrm{C}$ 
The corrosion of A537 in the dilute $\mathrm{pH} 12$ waste chemistry was pitting and a general localized corrosion for all temperatures and glycolate conditions. In a review of the solution chemistry, however, sodium nitrite, a necessary inhibitor for A537 was inadvertently left out of the solution. The CPP scans as shown in Figure 3-26 clearly showed a positive hysteresis. Pits of variable depths were found on the sample with the largest measured pit being approximately $10 \mu \mathrm{m}$. Under all conditions a passivation nose was observed at approximately $-0.025 \mathrm{~V}$. For the $\mathrm{pH} 6$ dilute waste chemistry at $30^{\circ} \mathrm{C}$, A537 showed active corrosion and the sample at the conclusion of the test was corroded across the surface. The corrosion rate of approximately 7 mpy may be considered acceptable depending on the application, the amount of use, and the ease of replacing the component.

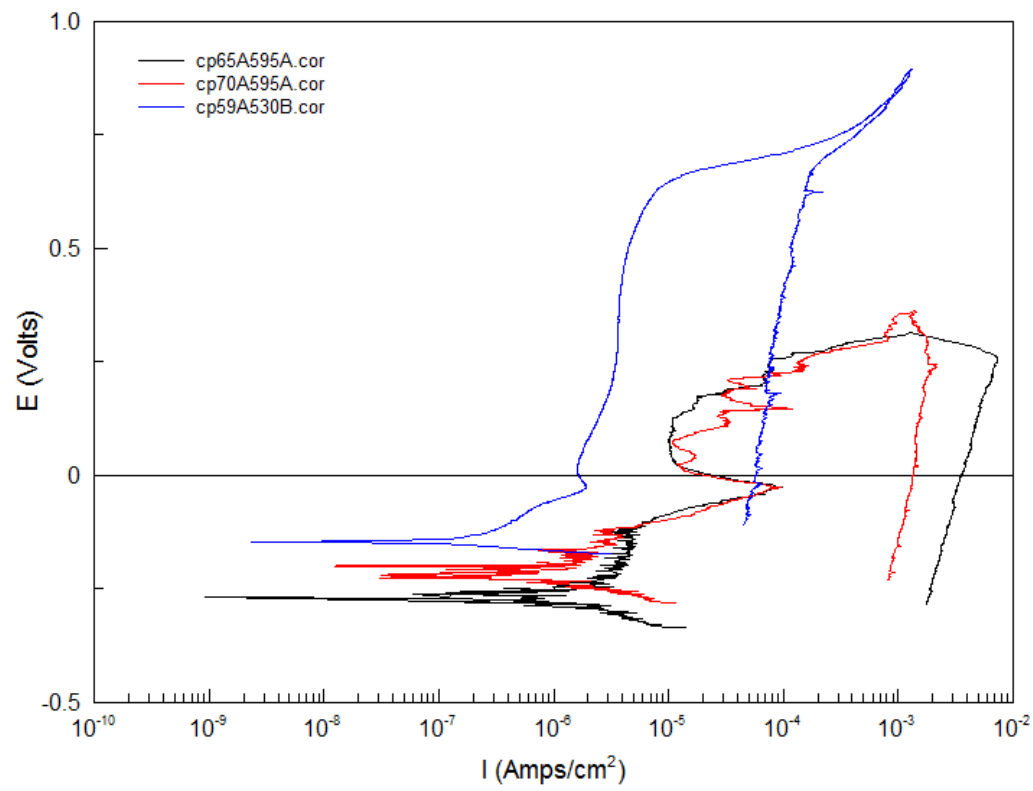

Figure 3-26 CPP scans for A537 in a dilute, $\mathrm{pH} 12$ waste chemistry with (cp65A595A) and without (cp70A595A) $0.033 \mathrm{~g} / \mathrm{L}$ sodium glycolate at $95{ }^{\circ} \mathrm{C}$ and with (cp59A530A and B) 0.033 $\mathrm{g} / \mathrm{L}$ sodium glycolate at $30^{\circ} \mathrm{C}$

\subsection{Hot-Wall Testing}

The hot-wall test is used to evaluate corrosion under heat transfer conditions that would be experienced during the heating cycle. The materials of construction (and heat transfer components) included C276 and Ultimet (SRAT and SME heating coils), G30 (2H tube bundle and warming coils) and G3 (ETF heaters). The results are summarized in Table 3-11.

Table 3-11 Hot-Wall Test Result for C276, Ultimet, G30 and G3

\begin{tabular}{|c|c|c|c|l||}
\hline Material & Solution & $\begin{array}{c}\text { Time in } \\
\text { Test (days) }\end{array}$ & $\begin{array}{c}\text { Weight Change } \\
\text { (g) }\end{array}$ & Corrosion \\
\hline C276 & SRAT/SME Supernate & 22 & $*$ & Pitting \\
\hline Ultimet & SRAT/SME Supernate & 34 & 0 & Pitting \\
\hline G30 & $\begin{array}{c}\text { Basic Concentrated } \\
\text { Recycle }\end{array}$ & 22 & $*$ & Pitting \\
\hline G3 & Dilute Waste & 27 & -0.0012 & Pitting \\
\hline
\end{tabular}

* Initial weight was not taken 
For the C276 alloy, the SRAT/SME supernate with a low iron and high aggressive species concentrations was used as the test solution (Category 2 solution). See Attachment 3 for the complete solution chemistry. The surface appearance after testing is shown in Figure 3-27.

During the test, the solution boiled off and left clumps of dried salts attached to the vessel walls and the sample. The root cause of the boil off was not determined, but the heater block appeared to be working and there were no leaks. The sample was cleaned to remove the dry solids. A new batch of solution was made and the test was started again. Recorded surface temperatures ranged from 171 to $216^{\circ} \mathrm{F}$ (77 to $\left.102{ }^{\circ} \mathrm{C}\right)$, which is below the surface temperature of the SRAT/SME heating coils $\left(164^{\circ} \mathrm{C}, 327^{\circ} \mathrm{F}\right)$. The heater block was at maximum output so higher temperatures could not be obtained, but the solution was rapidly boiling at these temperatures.

The initial weight of the sample was not measured, but an average of three other samples from the same set was $129.635 \pm 0.572 \mathrm{~g}$ with the largest weight of $130.1011 \mathrm{~g}$. The weight of this sample after cleaning was $130.0833 \mathrm{~g}$. Compared to the average weight of used coupons, the test sample would have gained weight. The white film as seen in Figure 3-27 (A) might be a thickened surface oxide. Compared to the largest weight, the test sample would have loss $0.0178 \mathrm{~g}$, which corresponds to a general corrosion rate of 0.7 mpy.

During the normal operation of the test no significant solids built up on the surface. The after cleaning photograph of the C276 surface is shown in Figure 3-27 along with a LCM laser optical image of the surface. Small pits were found to have formed in the one-month period. The pits did not appear to have a hemispherical shape. The angularity of these pits may indicate that surface imperfections may be the initiation sites for these pits. Grooves from the surface preparation process were also found to deepen. Qualitatively, these trenches appear to be deeper under the gaskets, indicating a possible susceptibility to crevice corrosion. The largest pit depth measured under the gasket was measured at $8 \mu \mathrm{m}$ while in the center the deepest measurement was $7 \mu \mathrm{m}$.

In the electrochemical test, C276 was found susceptible to pitting as demonstrated by either pitting in the sample after the tests or a positive hysteresis in the CPP scan. The hot wall test results are in agreement with those from the electrochemical test. Higher temperatures of the actual coils would be expected to accelerate the observed corrosion. .

For Ulitmet, the testing was conducted also in the SRAT/SME supernate with the low iron and high aggressive species concentrations (Category 2 solution). The sample was in test for 34 days. The thermocouple for measuring the solution temperature near the surface failed half way through the test. The temperature to that point ranged between 206 and $214^{\circ} \mathrm{F}\left(97\right.$ and $101{ }^{\circ} \mathrm{C}$ ). The solution was rapidly boiling at these temperatures. No weight change was noted in the sample. Figure 3-28 shows the sample at the conclusion of the test and after cleaning. The surface appeared as if minimal degradation had occurred. Grinding marks could still be seen. With closer examination using the LCM, pits were found both near the gasket and in the center of the sample as shown in Figure 3-28. The susceptibility to localized corrosion is similar to that found for the electrochemical testing. A few pits were measured at each location. The deepest pit in the gasket region was $42 \mu \mathrm{m}$ and in the sample center was $20 \mu \mathrm{m}$.

The G3 alloy, a Ni-Cr-Fe alloy, was tested in a dilute waste chemistry (Category 8 solution) that simulated the feed for the ETF evaporator. As shown in Table 3-11, the hot wall test lasted 27 days with temperatures of the solution at the heat-transfer surface ranging from 188 to $196{ }^{\circ} \mathrm{F}$ ( 87 to $91{ }^{\circ} \mathrm{C}$ ). The solution was boiling although lightly. The sample lost a small amount of weight over the course of the test, which corresponds to a corrosion rate of approximately $0.25 \mathrm{mpy}$. The post-test appearances of the sample before and after cleaning are shown in Figure 3-29 (A) and (B). 

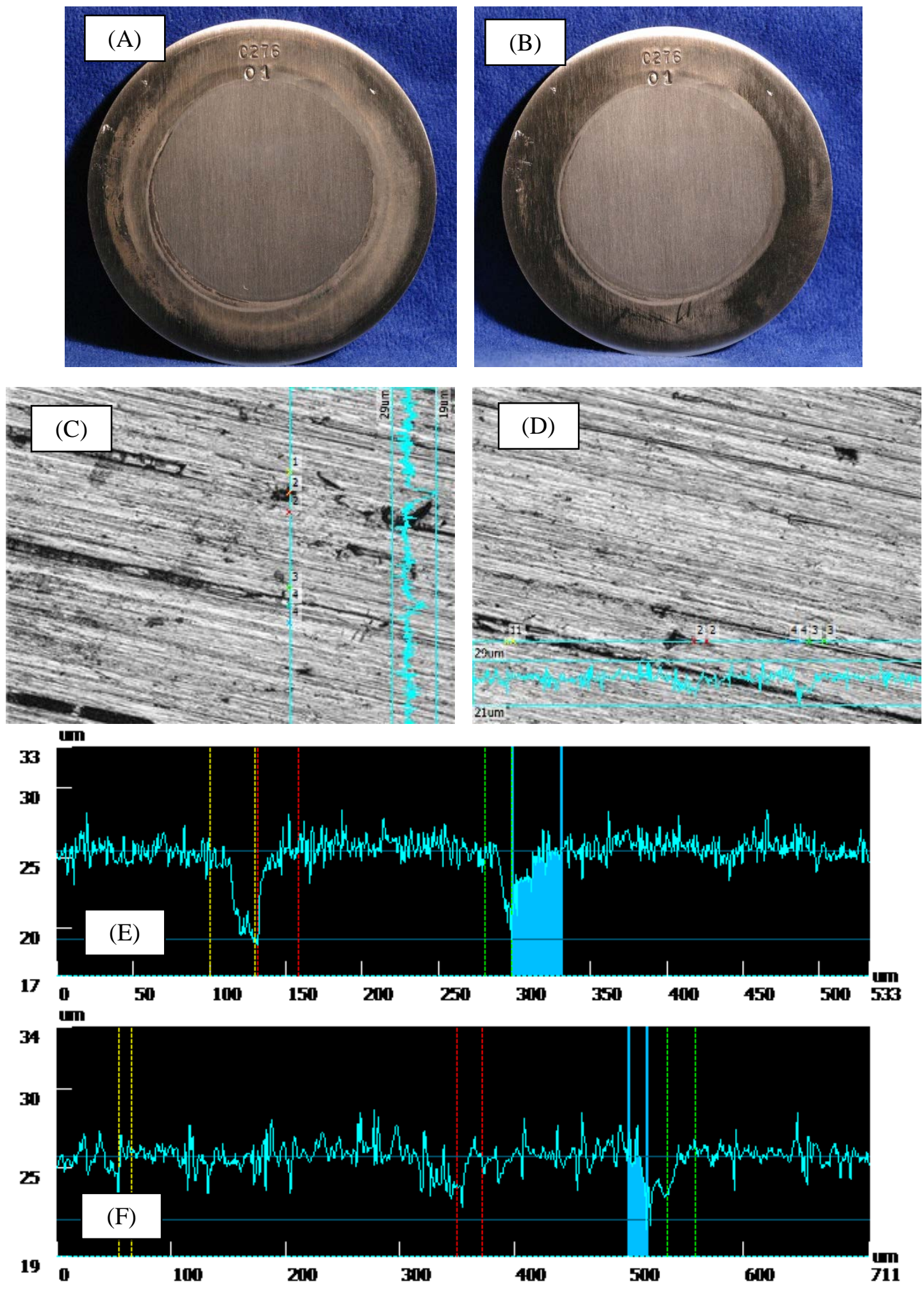

Figure 3-27 C276 hot-wall sample after 22 days exposed to the SRAT/SME supernate chemistry with low iron and high aggressive species concentrations: (A) 35-mm photograph before cleaning; (B) 35-mm photograph after cleaning; (C) LCM laser image of surface under gasket; (D) LCM laser image of surface at sample center; (E); LCM height scan showing pit depths under gasket and (F) LCM height scan showing pit depths at sample center 


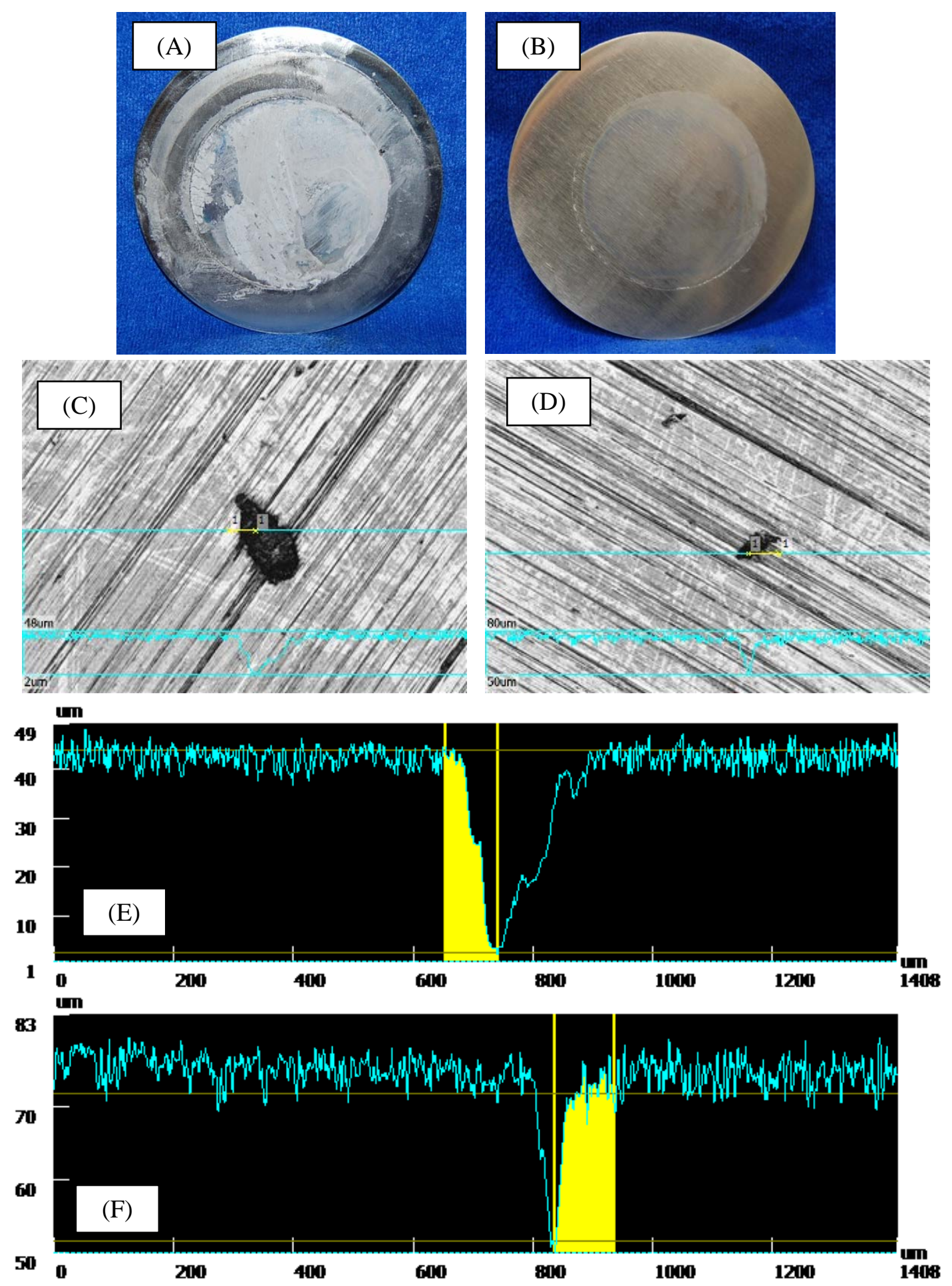

Figure 3-28 Ultimet hot-wall sample after 34 days exposed to the SRAT/SME supernate chemistry with low iron and high aggressive species concentrations: (A) 35-mm photograph before cleaning; (B) 35-mm photograph after cleaning; (C) LCM laser image of surface under gasket; (D) LCM laser image of surface at sample center; (E); LCM height scan showing pit depths under gasket and (F) LCM height scan showing pit depths at sample center 

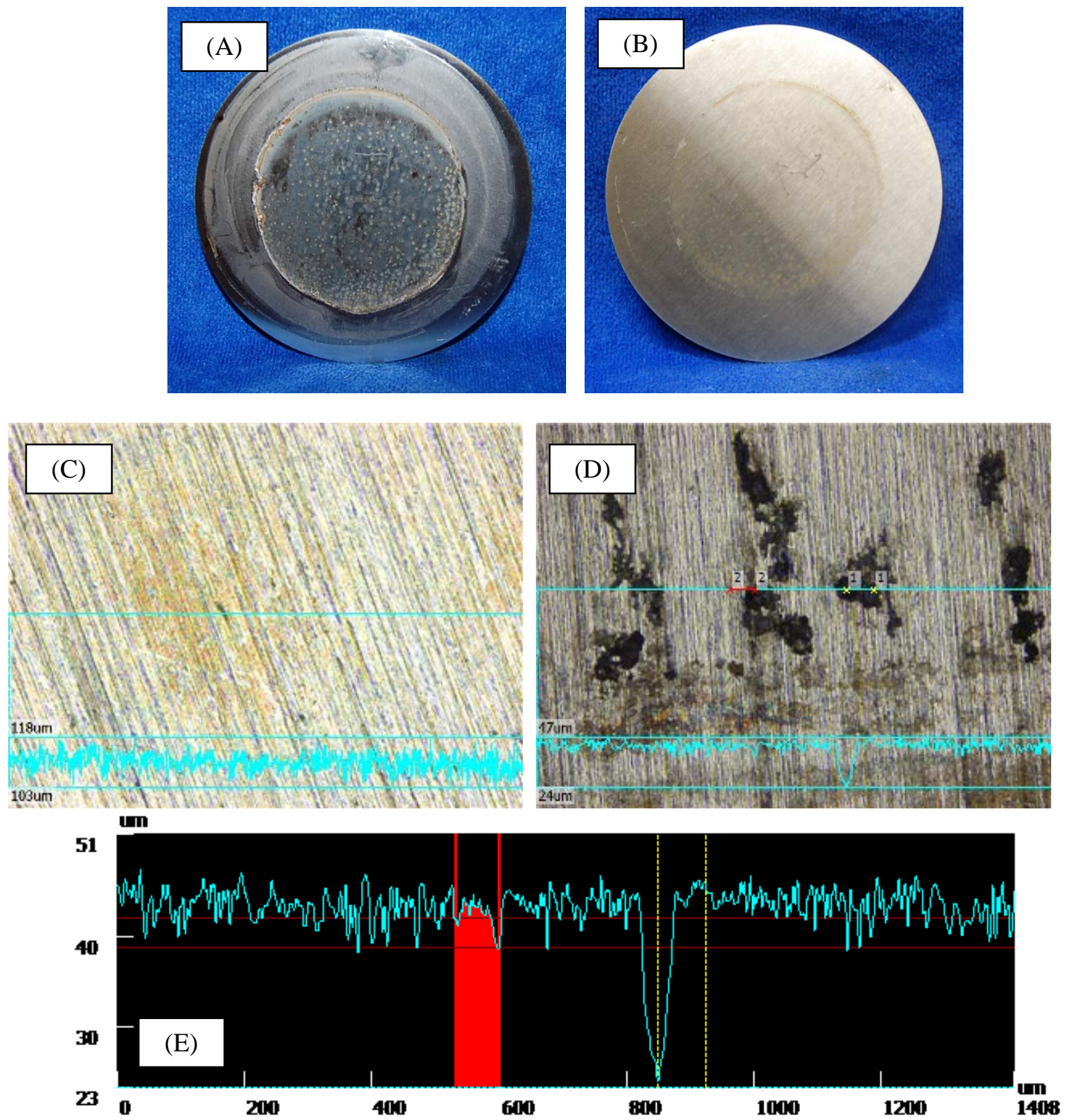

Figure 3-29 G3 hot-wall sample after 27 days exposed to a dilute waste chemistry: (A) 35-mm photograph before cleaning; (B) 35-mm photograph after cleaning; (C) LCM laser image of surface at sample center; (D) LCM laser image of surface near gasket; (E); LCM height scan showing pit depths under gasket

The pit-like spots seen in the photographs were found not to be pits as shown by the laser image and height scan in Figure 3-29 (C). If the sample was exposed longer these areas may have developed into pits. Pits were found as in the other samples near the gasket. The deepest measured pit was $22 \mu \mathrm{m}$. The electrochemical results showed a passive curve with negative hysteresis that would not indicate pitting or crevice corrosion. One electrochemical sample did have the surface oxide changed color indicating some reactivity to this solution. 
The G30 alloy, a high chromium nickel based alloy, was tested in the basic recycle chemistry (Category 5 solution) that simulated the feed for the $2 \mathrm{H}$ evaporator. As shown in Table 3-11, the hot wall test lasted 22 days with temperatures of the solution at the heat-transfer surface ranging from 205 to $214^{\circ} \mathrm{F}$ (96 to $101{ }^{\circ} \mathrm{C}$ ), so the solution had a robust boil. The post-test appearances of the sample before and after cleaning are shown in Figure 3-30 (A) and (B).
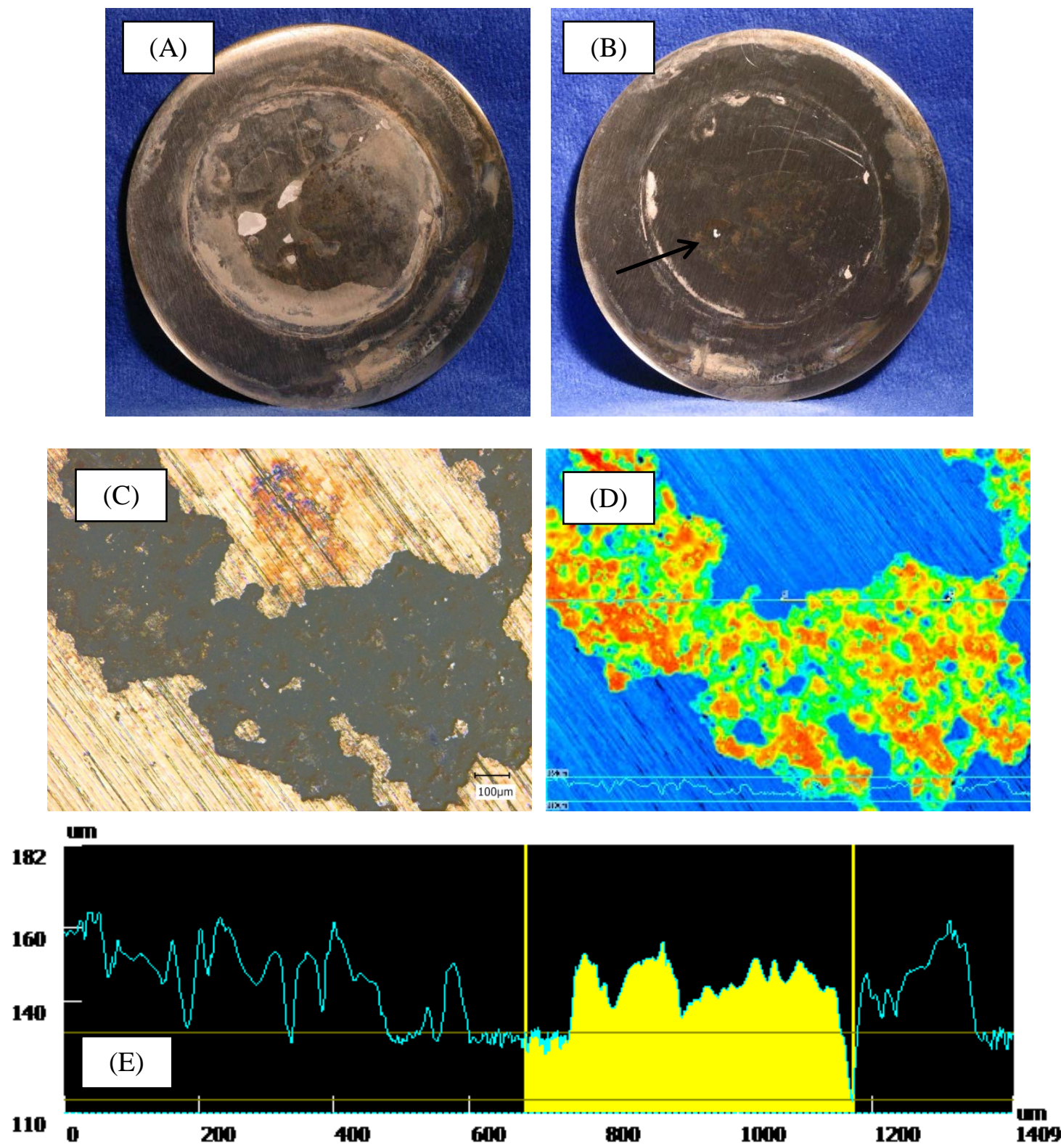

Figure 3-30 G30 hot-wall sample after 22 days exposed to a basic recycle waste chemistry: (A) 35mm photograph before cleaning; (B) 35-mm photograph after cleaning; (C) LCM laser image of deposit at sample center; (D) LCM height image of deposit at sample center; and (E); LCM height line scan showing pit depths with the deposit

The initial weight of the sample was not measured, but an average of three other samples from the same set was $115.0665 \pm 1.3488 \mathrm{~g}$ with the greatest weight of $116.4187 \mathrm{~g}$. The weight of the G30 sample after cleaning was $116.9888 \mathrm{~g}$. Compared to either the average or greatest weight of unused coupons, the test 
sample would have gained weight. This weight gain is associated with the oxide film and deposits (see Figure 3-30 (B)) that were not easily removed from the sample using the standard cleaning methods.

Pitting was observed on the G30 sample and was associated with the deposits. Figure 3-30 (C) shows a laser scan of a deposit in the center of the exposed area (which is indicated by an arrow in Figure 3-30 (B)) and Figure 3-30 (D) shows the height image of the same area. The line scan through one of the dark blue spots shows a pit of depth $18 \mu \mathrm{m}$ (Figure 3-30 (E)). Pitting was observed only associated with the adherent deposits. Crevice corrosion associated with the gasket was not observed on this sample as was observed on other hot-wall samples.

The results from these hot-wall tests have shown that pitting is a prevalent corrosion mechanism in the presence of glycolic acid under heat transfer conditions. There are several aspects of the testing that need to be further assessed to determine if the results are fully applicable to service conditions. No testing was performed without glycolic acid and it is recommended that such testing be conducted especially since pitting was commonly associated with the crevice formed by the gasket. For the testing in the SRAT/SME superrnate testing in the presence of the glycolate anion should also be conducted at concentrations of aggressive species that are expected from feed waste chemistries. These tests may show that lower limits for aggressive species may be necessary for safe operation of the CPC vessels.

\subsection{CPC 22-L Test - C276 Coupons}

Coupons were exposed during the prototypical CPC tests conducted to evaluate the impact of glycolic acid on the SRAT and SME vessels (22-L CPC Testing). Two C276 coupons were exposed for the two batch run of the 22-L vessel testing. The testing was a scale up from the 4-L testing. The total time of exposure was 170 hours. After testing the coupons were rinsed off and dried. No precautions were taken to protect the coupons from the atmosphere. The coupons were photographed, cleaned in a $0.1 \mathrm{M}$ nitric acid solution, weighed, and photographed. Photographs of the coupons before and after cleaning are shown in Figure 3-31. As can be seen in the photograph of the after cleaning pictures no significant corrosion occurred during the exposure. No weight change was measured in these coupons.

\subsection{Discussion}

The corrosion testing in simulants for the SRS waste processing system has shown that the glycolate anion has a variable impact on the corrosion of the materials of constructions throughout the system. The most significant impact is within the CPC where the glycolate anion concentration is greatest $(63 \mathrm{~g} / \mathrm{L})$ and temperatures, especially on heat-transfer surfaces, are the hottest $\left(164{ }^{\circ} \mathrm{C}\right)$. For several of the material/simulant combinations, the impact of the glycolate anion on the general corrosion rate was undetectable, although changes in the electrochemical response were discernible. These small changes, however, are not expected to impact service life.

In the electrochemical results, the presence of the glycolate anion shifted the OCP, either more electropositive or electronegative. The shift in OCP was fairly consistent for alloys tested in the same simulant, but no correlation to solution chemistry was found for the direction of the shift. Another change in the presence of the glycolate anion was that $\mathrm{i}_{\mathrm{p}}$, which was measured at a potential $200 \mathrm{mV}$ from the OCP, was always greater than for a glycolate-free solution. Some of these increases were small and may be considered within the experimental variability. However, higher $i_{P}$ values are associated with a less protective oxide.

For the SRAT/SME supernate, C276, Ultimet and Stellite had general corrosion rates of approximately 10 mpy or less.. These corrosion rates were measured for all alloys in the electrochemical tests, for C276 and Ultimet in the hot-wall tests and for C276 in the coupon exposures during the CPC 22-L tests. Based on these rates, the components fabricated from these alloys would not be expected to be compromised in 
service. For these alloys, pitting corrosion was also found to occur under most conditions during the electrochemical testing, even at the low levels of aggressive species (chloride, sulfate and mercury).
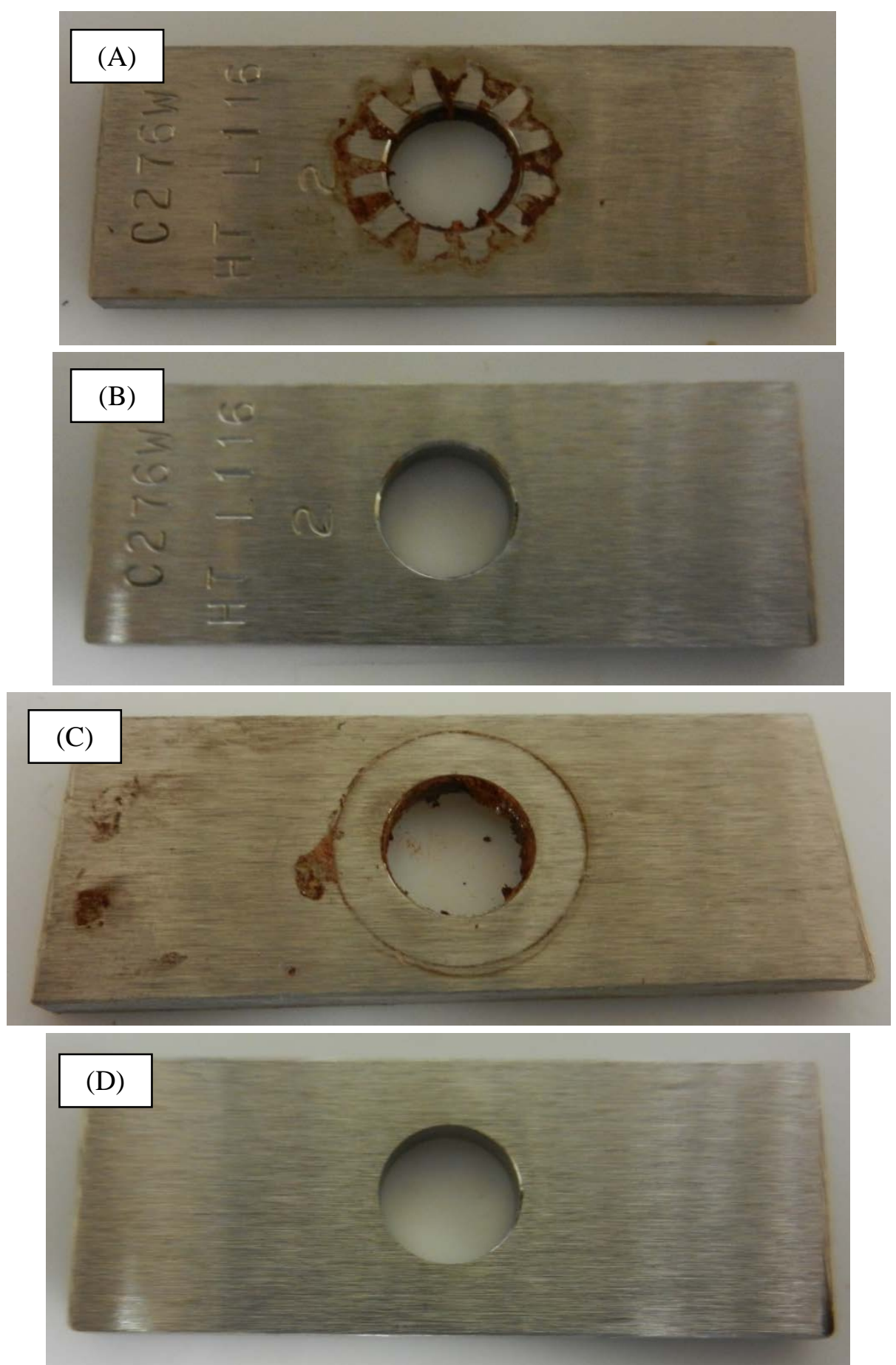

Figure 3-31 Photographs (35-mm) of C276 coupon \#2 after exposure during the 22-L CPC testing (A) front before cleaning; (B) front after cleaning; (C) back before cleaning; and (D) back after cleaning

The pitting is of concern for C276, since as the material of construction for the vessels, it performs a containment function within the CPC vessels. Pitting was also observed during the hot-wall testing for 
both C276 and Ultimet, which may be applicable to the coils but not the tank walls. The hot-wall tests were performed at high concentrations of aggressive species $(0.052 \mathrm{M}$ sulfate, $1 \mathrm{wt} \%$ chloride, and mercury present). Pitting was not observed in C276 during the CPC prototypical testing which saw total coupon exposure time of 170 hours. The difference in observed corrosion for the CPC prototypical and electrochemical testing may be due either to the shortness of the test time for the CPC prototypical test, which did not allow sufficient time for localized corrosion to develop, or that the accelerated conditions of the electrochemical does not occur in the CPC prototypical test conditions.

Test data in solutions with a formic acid flow sheet are not available for comparison except for one reference. The paper briefly discussed some electrochemical and hot wall tests in HLW precipitate slurries for C276, but did not present actual data nor describe the experimental set up [21]. In the electrochemical tests at $95{ }^{\circ} \mathrm{C}$, C276 showed passive behavior in all chemistries which ranged in pH from 2- 9 and had aggressive species of chloride (1014 - $1851 \mathrm{ppm})$ and sulfate (33 - $736 \mathrm{ppm})$. Mercury was not noted to be in the solution. A hot-wall test was performed in one solution (pH 4, $1014 \mathrm{ppm} \mathrm{Cl}^{-}, 167$ ppm $\mathrm{SO}_{4}^{-2}$ ). The $\mathrm{C} 276$ sample had deposits but no pitting. The corrosion rate was determined to be 0.01 mpy.

Further testing is recommended to determine long-term impact of glycolate on the materials of construction in the SRAT/SME supernate. Coupon immersion tests are recommended at the temperature of operation for an extended exposure (i.e. three months). This testing should be conducted at an expected level of aggressive species as well as at an elevated level. Testing in the formic acid-based supernate should also follow a similar suit of electrochemical tests performed here for the glycolic acidbased supernate. These tests should include the three primary alloys of C276, Ultimet and Stellite.

In the SME condensate simulant, the presence of the glycolate anion had a negligible effect on 316L and caused a slight increase in the general corrosion rate of 304L. This slight increase is not expected to impact the life time of these components. The impact of the glycolate anion although small still impacted the electrochemical properties with shifts in the OCP to more electronegative values and $i_{P}$ to higher values.

In the acidic recycle stream (Category 4 solution), both AllCorr and C276 showed a greater general corrosion rate with the glycolate anion present. The general corrosion rate for C276 was three times higher. The highest measured rate was $3.2 \mathrm{mpy}$, which is still below the value evaluated within the structural integrity program [23], so would not be expected to impact service life.

The concern for AllCorr is the susceptibility to pitting at neutral $\mathrm{pH}$ values which is surprising considering the alloy contains high levels of nickel, chromium and molybdenum. The measured pit protection potential, which was 0.4 to $0.7 \mathrm{~V}$ away from the OCP, indicated that pitting should not be a problem if condensate $\mathrm{pH}$ values were expected to be near neutral. Since condensates are expected to be acidic, the impact to AllCorr is considered small and should not impact the lifetime of the quencher.

In the basic recycle stream (Category 5 solution), the G30 alloy showed pitting during the hot-wall testing, although no indication of pitting was found from the electrochemical results. The pitting in the hot-wall test was clearly associated with deposits formed on the surface. The hot-wall testing is recommended to be repeated with changes in the solution chemistry over the course of the test to minimize solution chemistry changes over the course of the test. The $2 \mathrm{H}$ evaporator tube bundles would be exposed to a waste stream of a fairly constant chemistry as opposed to the solution which obviously changed over the course of testing. The solution formed precipitates as time went on through the test as noted by the surface deposits. 
In both the salt processing simulant and the simulant for the MCU contactors, there was no localized corrosion noted and all general corrosion rates were acceptable ( $<2$ mpy).

In the dilute waste simulant, the G3 alloy showed pitting during the hot-wall testing. This pitting was associated with the gasket. Pit like features were noted on the center of the coupon, but had no significant depth. The electrochemical results did not indicate any pitting. The difference could be the heat-transfer, although changes in solutions could also be a contributing factor. Similar to the G30 in the acidic recycle simulant, a repeated hot-wall test is recommended with more frequent solution changes over the course of the test, which will provide better control and replicate the actual service exposure.

\subsection{Results and Discussion - Melter Materials of Construction}

The CEF test was performed to define the DWPF flammability envelope for the nitric-glycolic acid flowsheet, but also provided a convenient approach to perform a coupon test for assessing the compatibility of the DWPF melter materials of construction (I690 and Monofrax ${ }^{\circledR}$ K-3) to this flowsheet. The analytical results of the coupons are discussed in this section.

\section{1 $\underline{\text { I690 Coupon }}$}

An argon-purged I690 bubbler, similar in design to that used in the DWPF melter, was inserted into the furnace during the CEF testing. The bubbler was fabricated from a 1/2 inch, schedule 160 pipe, which had a nominal diameter and wall thickness of 0.840 and 0.187 inches, respectively. The bubbler assembly was approximately 34 inches long from the flange to the bottom block that contained the argon discharge orifice (Figures 4-1 and 4-2).

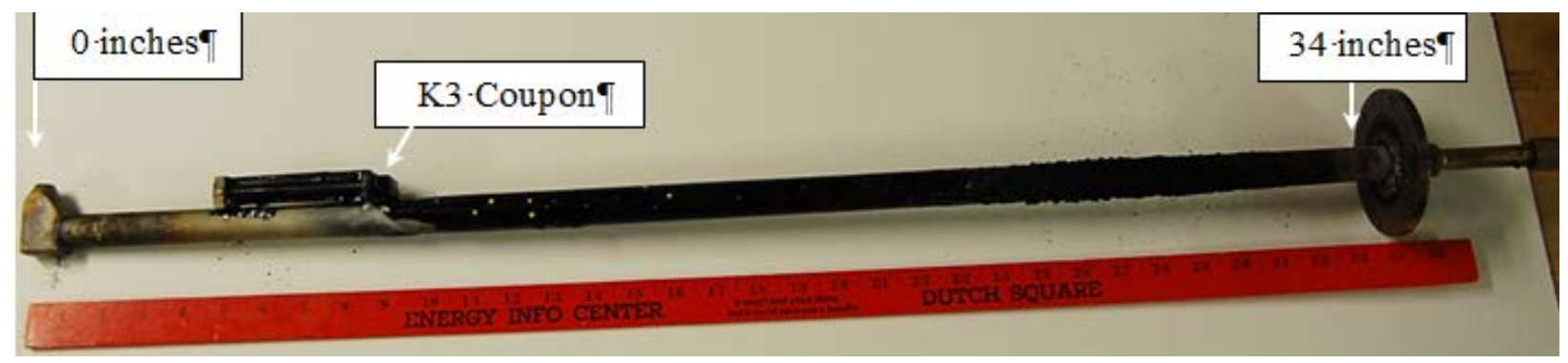

Figure 4-1 Glass-coated I690 bubbler in post-test condition showing location of refractory K-3 coupon
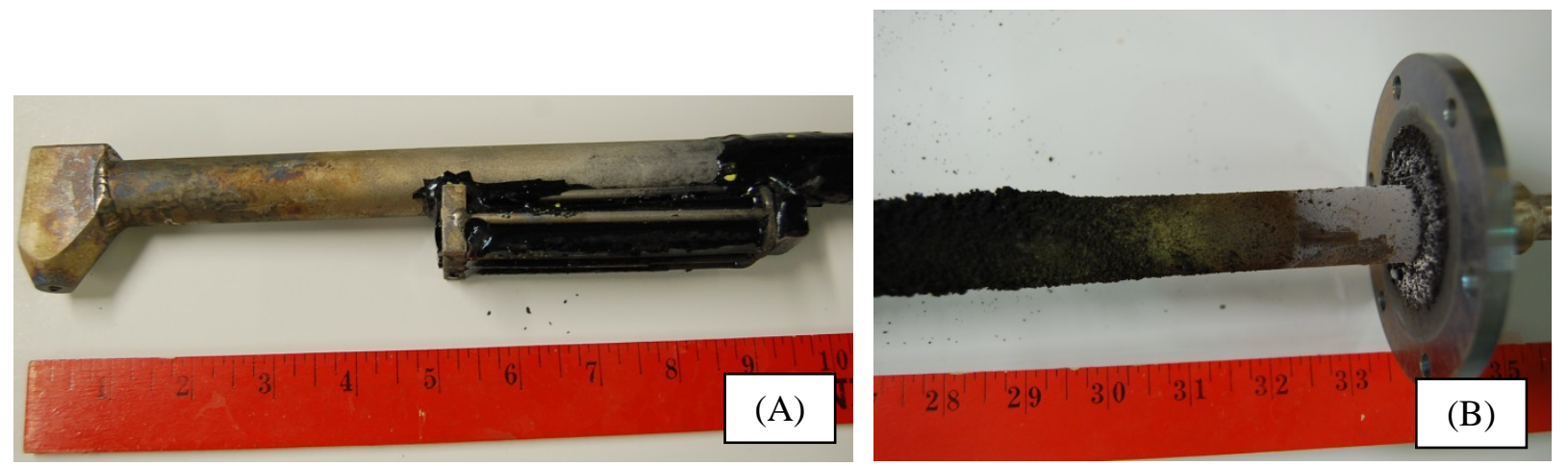

Figure 4-2 Glass-coated I690 bubbler in post-test condition: (A) glass-coated K-3 refractory coupon in I690 holder and (B) flange and bubbler tube in the vapor space region 
An approximately 4-inch long K-3 coupon was mounted on the discharge side of the pipe in a I690 cage as shown in Figure 4-2 (A). The CEF was operated for a total of 25 days. During this time the average melt pool temperature was $1050^{\circ} \mathrm{C}$. The measured glycolate anion concentration ${ }^{3}$ ranged from 34,665 to $43,250 \mathrm{mg} / \mathrm{Kg}$ for the stoichiometry and antifoams spikes used during testing. The argon flow was variable ranging from 0.003 to $1.040 \mathrm{scfm}$ and the feed chemistry contained concentrations of the aggressive anions $\mathrm{Cl}^{-}$and $\mathrm{SO}_{4}^{-2}, 300$ and $1200 \mathrm{ppm}$, respectively. A plot of the furnace temperature profile and argon flow rate is shown in Figure 4-3.

A metallographic examination was performed to evaluate the condition of the bubbler. The evaluation was performed to determine the total degradation resulting from corrosion (molten glass and oxidation) observed in the three primary regions of the melter, the melt pool, melt line, and vapor space. Total degradation includes material loss due to molten glass corrosion and the depth of internal attack resulting from intergranular attack (IGA) and oxidation. The examination included a visual and dimensional evaluations and an SEM analysis.

\subsubsection{Visual and Dimensional Evaluations}

Visual examination of the bubbler did not reveal any obvious degradation on any surface. No evidence of a crystalline surface morphology beneath the glass or deposits indicative of an intergranular attack was observed on any portion of the bubbler. Flow lines in the weld fusion zones were distinct and machining marks were still visible on the lower block around the discharge orifice. The edge around the orifice was distinct and showed no evidence of degradation from the flowing argon gas or molten glass. Photographs of the post-test bubbler after sectioning are shown in Figure 4-4. Portions of the bubbler pipe that were removed for metallurgical examination from the melt pool, melt line, and vapor space regions correspond to the following elevations as measured from the bottom of the bubbler, 2 inches, 23 inches, and 31 inches.

Dimensional measurements were performed using a Vernier caliper. The calipers were used because most regions of the bubbler were free of deposits or glass. Measurement of the melt line region was not practical using the calipers because heavy deposits of glass and partially melted feed were tenaciously bound to the pipe surface. Therefore, the wall thickness in the melt line region was measured using Scanning Electron Microscope (SEM) images from the metallurgically mounted sample. Results indicated the wall thickness in this melt line region was 0.1898 inches (nominal thickness 0.1870 inches). The outer diameter of the pipe in the vapor, melt pool, and from a low temperature region just outside the furnace ranged between 0.8398 and 0.8400 inches (nominal pipe diameter was 1.05 inch). All measurements indicated there was no dimensional change (material loss) within the precision of the measurement methods.

\footnotetext{
3 The technique for measuring the glycolate anion concentration is imprecise with measurements being below actual concentrations. Technique development is currently being performed at SRNL to improve these measurements.
} 


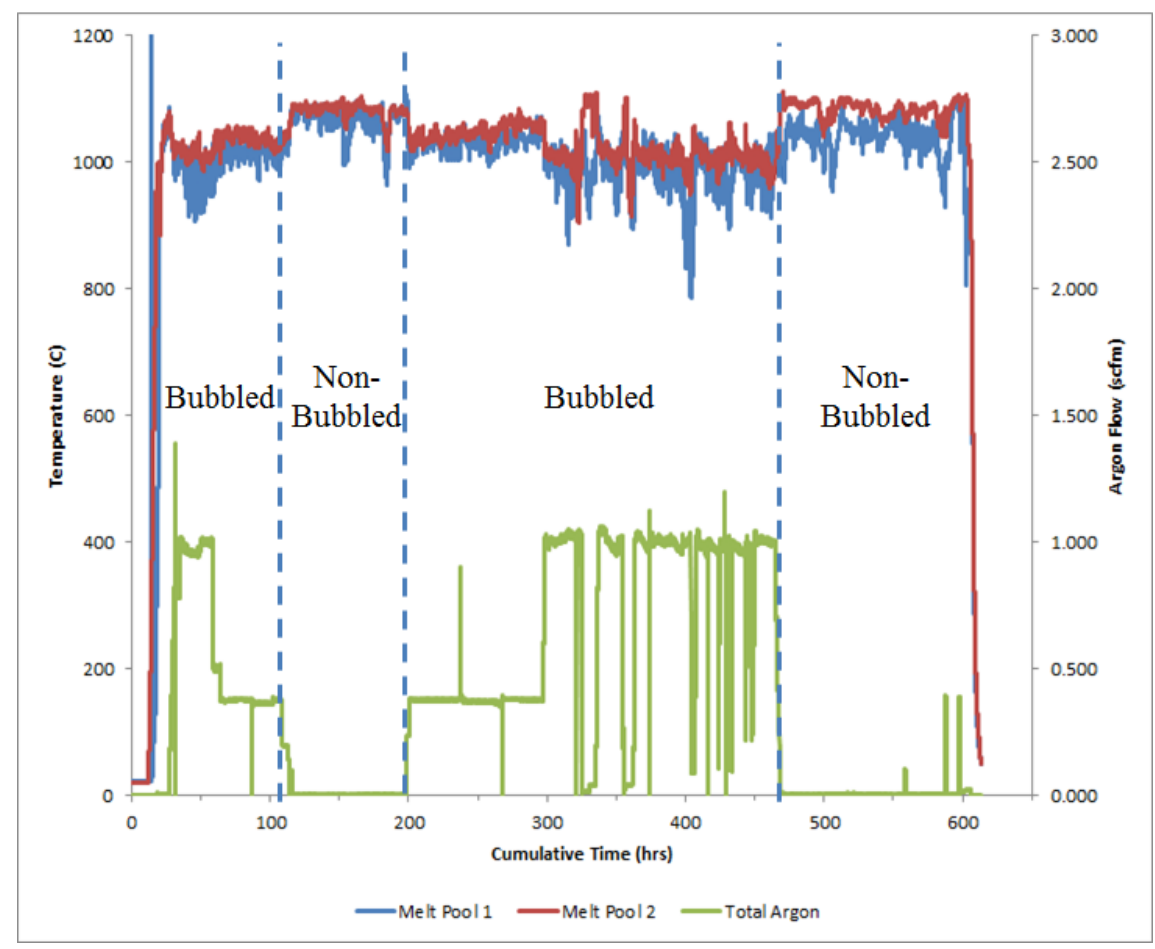

Figure 4-3 CEF temperature profile and argon flow rate during the 25 day CEF glycolic acid flowsheet campaign

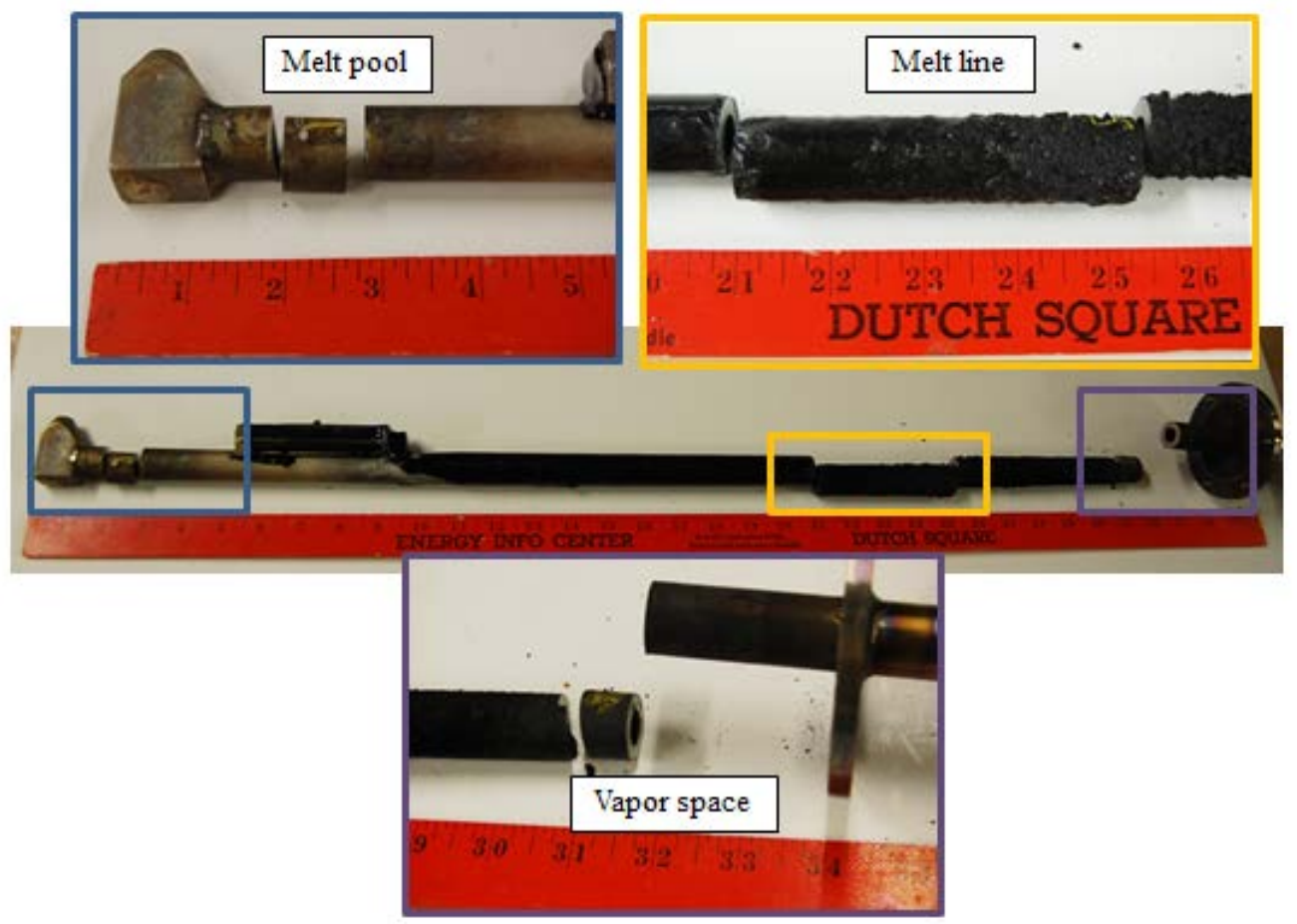

Figure 4-4 Photographs showing final sectioning of the 690 bubbler for the samples taken from the melt pool, melt line and vapor space regions 


\subsubsection{SEM Results}

The SEM results are presented for a sample of as-received I690 piping and the samples sectioned from the different regions of the bubbler as shown in Figure 4-4: melt pool, melt line and vapor space.

\subsubsection{1 .As-Received}

Metallographic specimens were prepared using standard metallurgical methods in preparation for examination with an SEM. An additional metallurgical sample was prepared from an as-received, unexposed section of 1/2 inches, schedule 160, I690 pipe. SEM images of the as-received pipe are shown in the Figure 4-5. Numerous shallow cracks were seen in the near surface region of the inner diameter of this pipe. Inspection at higher magnification revealed the cracks were very narrow and filled with oxide. The deepest crack was 2.16 mils deep. The regions adjacent to the cracks were deformed and had the appearance of a lap. The exterior surface of the pipe was uniform and did not exhibit any unusual features similar to those found on the inner surface Figure 4-6.
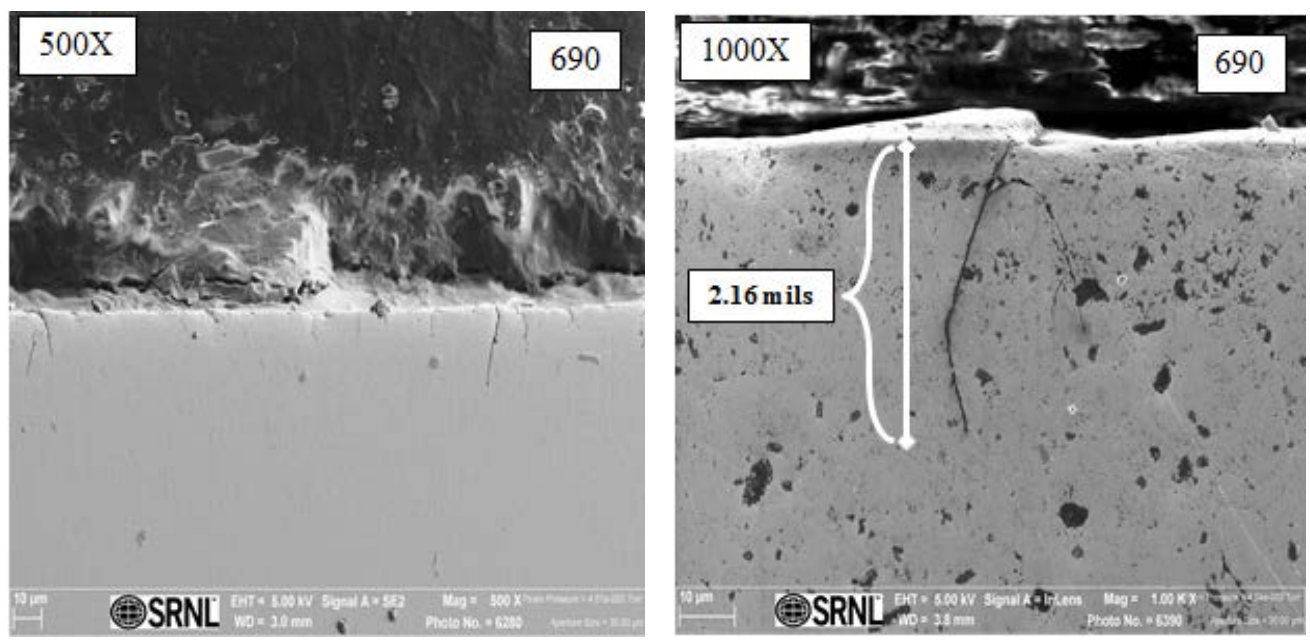

Figure 4-5 SEM images of the inner diameter surface of an as-received, unexposed section of I690 pipe where shallow cracks, approximately 2 mils deep, are visible below the deformed metal which appears to be a lap

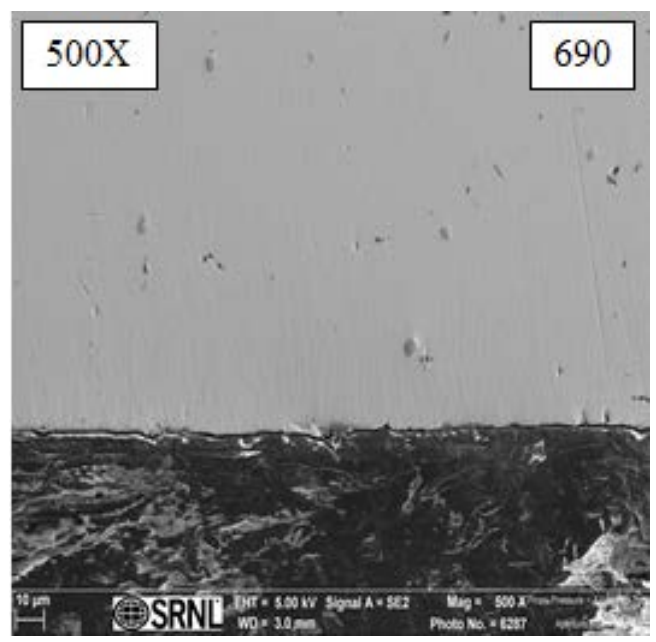

Figure 4-6 Secondary electron image of the outer diameter surface of an as-received, unexposed section of I690 pipe, where no cracking visible on surface 


\subsubsection{Melt Pool}

The melt pool sample showed evidence of the initial stages of IGA. Although islands of chromium oxide were visible to a depth of approximately 2.36 mils, they had not coalesced to form a clear path down the grain boundaries. No internal voids were observed as shown in Figure 4-7 (A). Pitting was evident on this surface but was extremely shallow. The depth of attack on the inner surface was approximately 2.76 mils, which is a slight increase from that observed in the as-received condition. However, the most pronounced feature was the cracks, which were originally narrow, had broadened and filled with chromium oxide (See Figures 4-7 (B) and 4-8). EDS dot map images of the outer surface, shown in Figure 4-9, show sulfur and oxygen had diffused into the metal lattice in the near surface region. Chromium oxide was not evident on this surface but may have been removed when the glass spalled upon cooling (See Figure 4-2 (A)). Sulfur was observed at the glass/metal interface on the inner diameter of the pipe (most likely due to glass intrusion under low or no argon flow conditions) but was not found to have diffused into the metal lattice. Chromium oxide was evident in the cracks in this region of the pipe but also did not appear to have diffused into the metal matrix (see Figure 4-10).

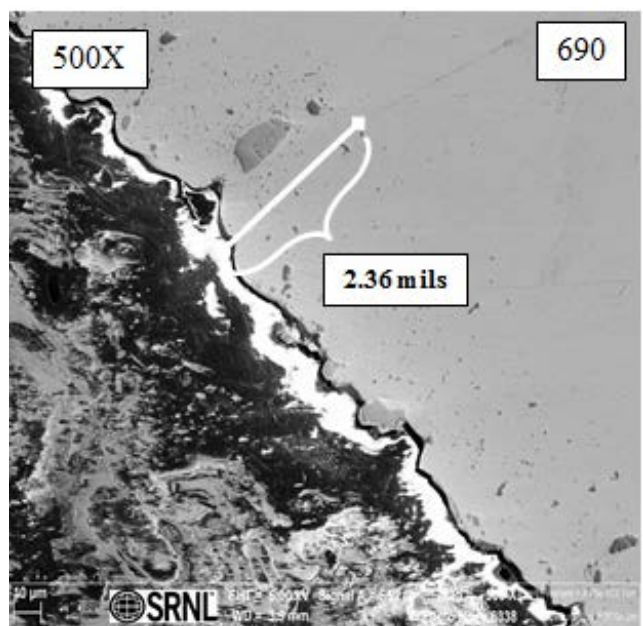

(A)

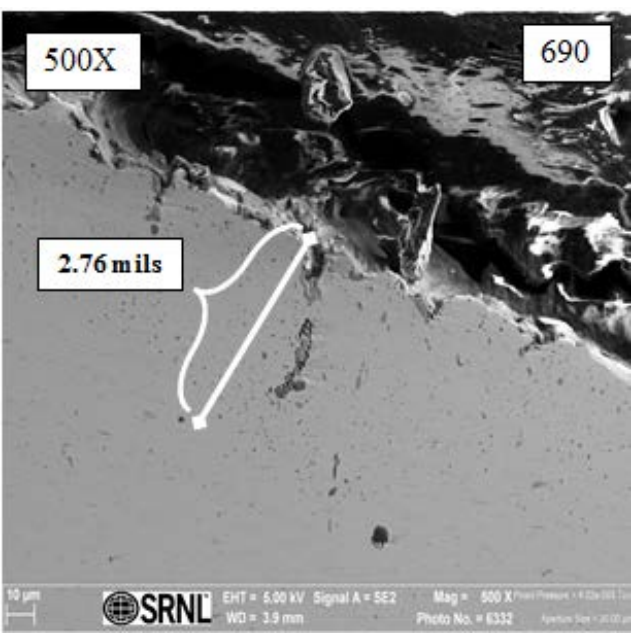

(B)

Figure 4-7 Secondary electron images of the outer (A) and inner (B) diameter surfaces of the melt pool regions (White bars indicate the average depth of internal attack)

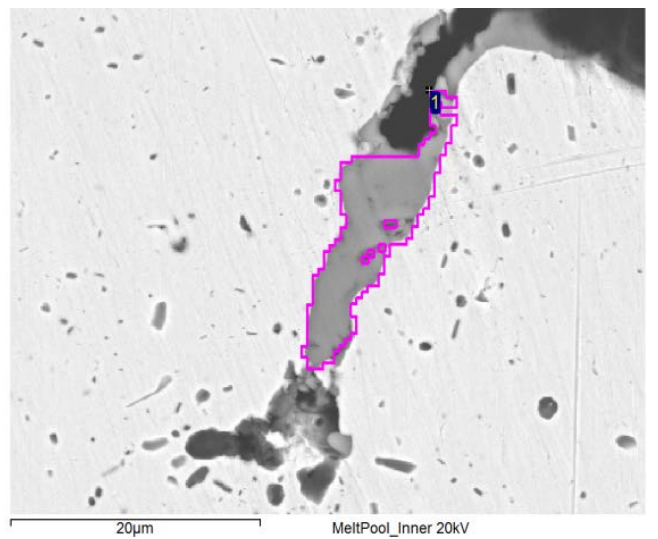

(A)

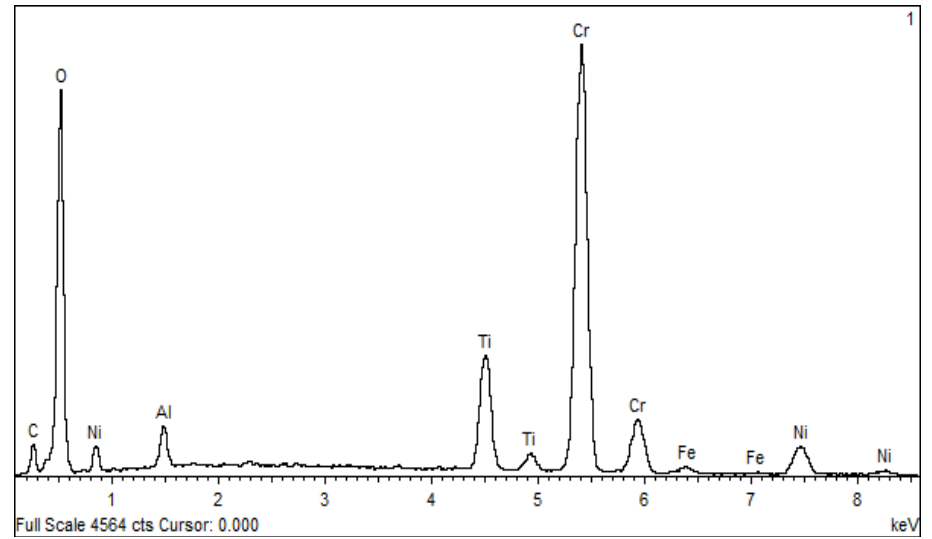

(B)

Figure 4-8 Crack on inner surface of the melt pool sample: (A) Secondary electron image and (B) EDS spectrum showing chromium oxide inside the crack 


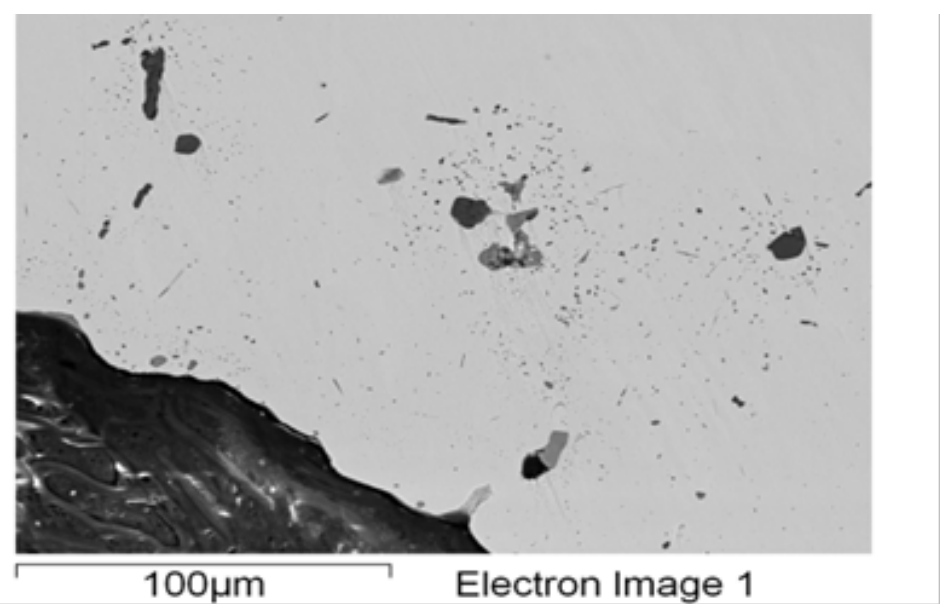

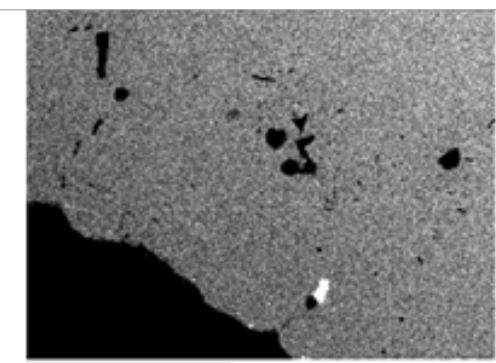

100um

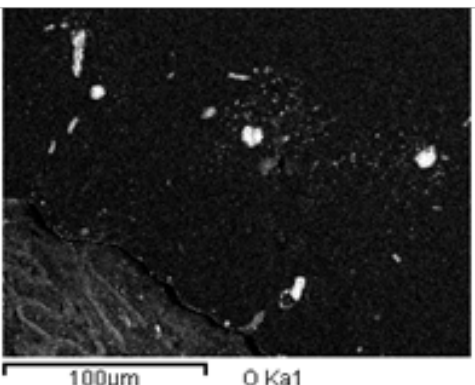

100um OKa1

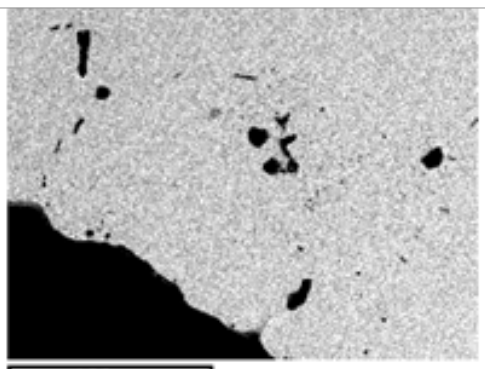

$\overline{100 \mu \mathrm{m}}$ Ni Ka1

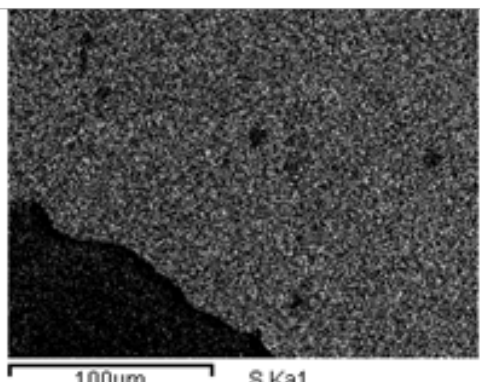

$100 \mathrm{um} \mathrm{SKa}$

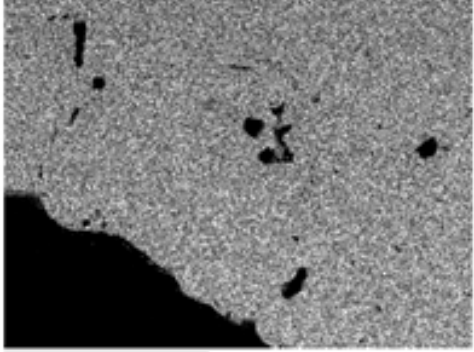

$\stackrel{100 \mu \mathrm{m}}{\longrightarrow}$ Fe Ka1

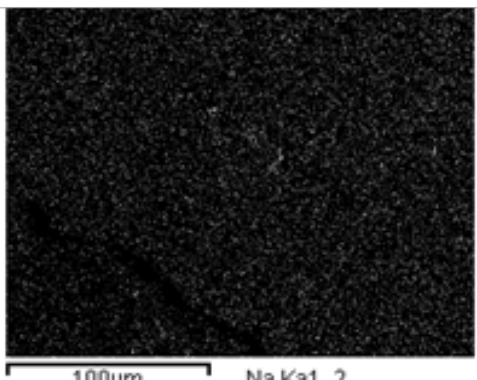

100um NaKa1_2

Figure 4-9 Secondary electron and dot map images for various elements from the melt pool outer surface. Note the diffusion of sulfur and oxygen into the metal lattice 

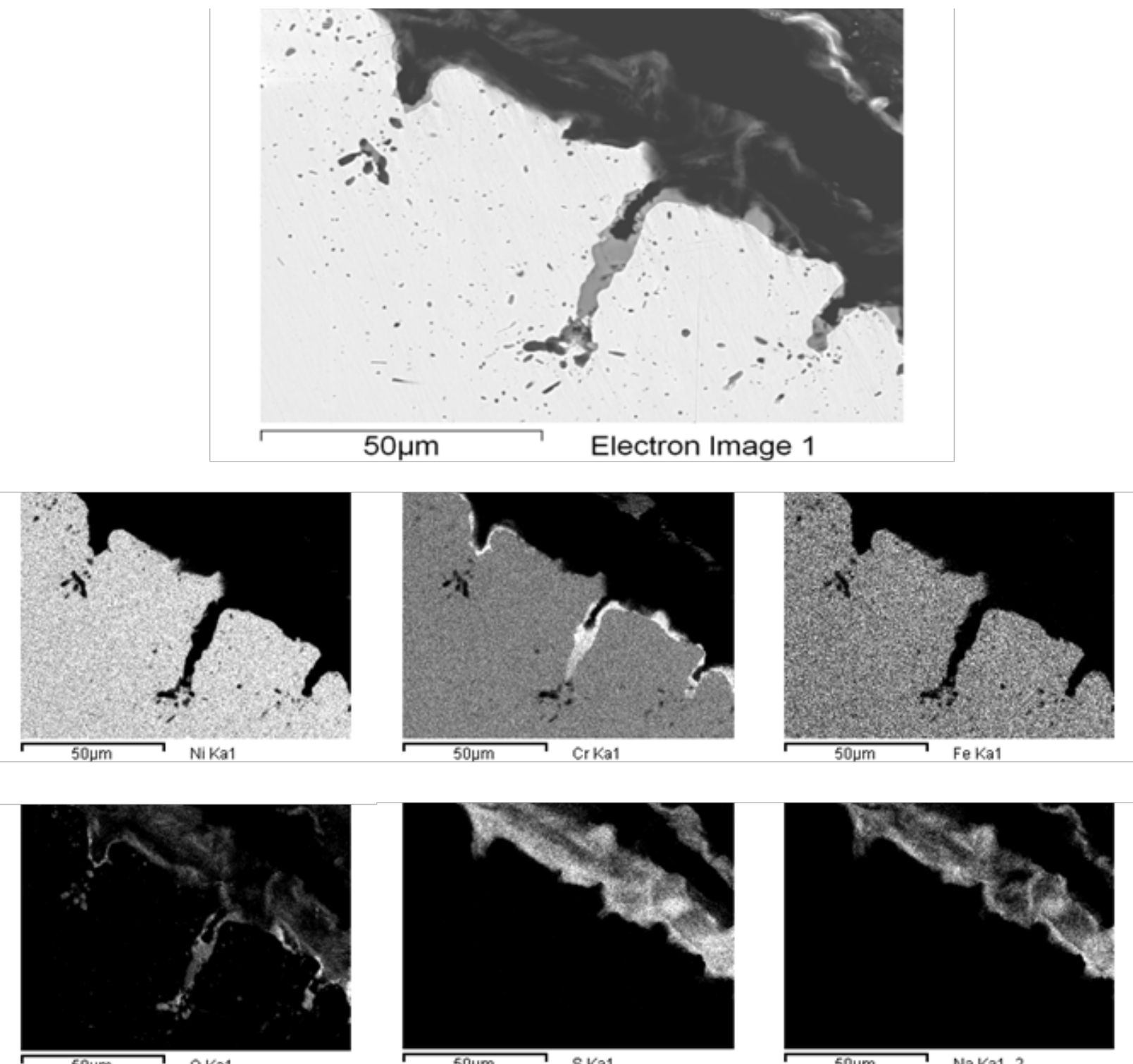

Figure 4-10 Secondary electron and dot map images for various elements from the melt pool inner diameter surface. Note the diffusion oxygen into the cracks and metal lattice. Sulfur is just present on the surface. Only a small amount of oxygen had diffused into the metal matrix (see arrow)

\subsubsection{Melt Line}

Intergranular attack is evident on the bubbler pipe outer diameter in the melt line region. The average depth of IGA was 0.98 mils (Figure 4-11). No pitting was observed on this surface. Cracks were observed on the inner diameter, 1.81 mils deep (Figure 4-12), but this was comparable to the crack depth observed on the as-received pipe section (2.16 mils). However, the cracks did broaden and have a chromium oxide layer on the surface. Chromium oxide was also observed on the outer diameter and characteristic chromium depletion was seen in the near surface region ( $\mathrm{Cr}$ dot map slightly darker in the near surface region) (Figure 4-13). Sulfur was observed on the surface with a small amount present in the intergranularly attacked region. 


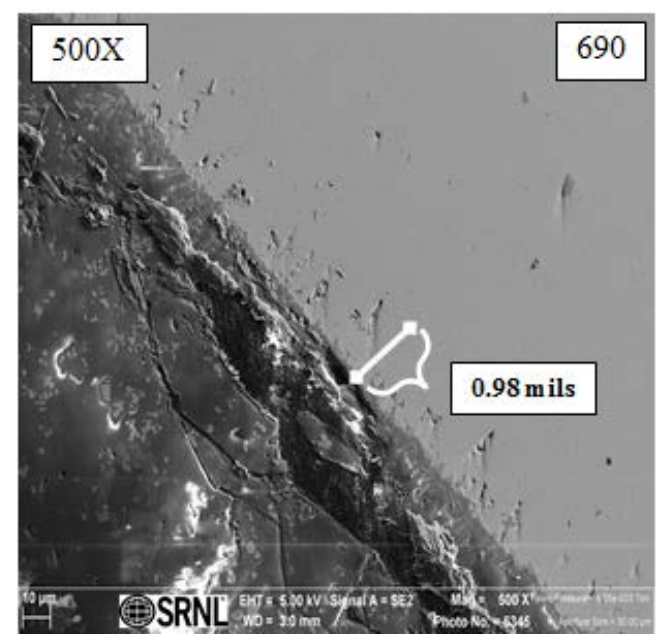

(A)

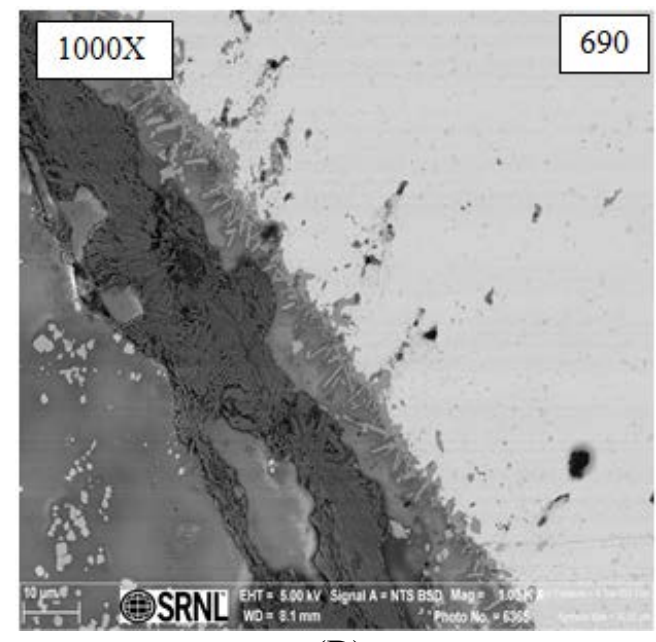

(B)

Figure 4-11 Secondary electron (A) and backscattered images (B) of the outer diameter from the melt line region. Rods visible along the metal surface shown in the BS image contain sulfur

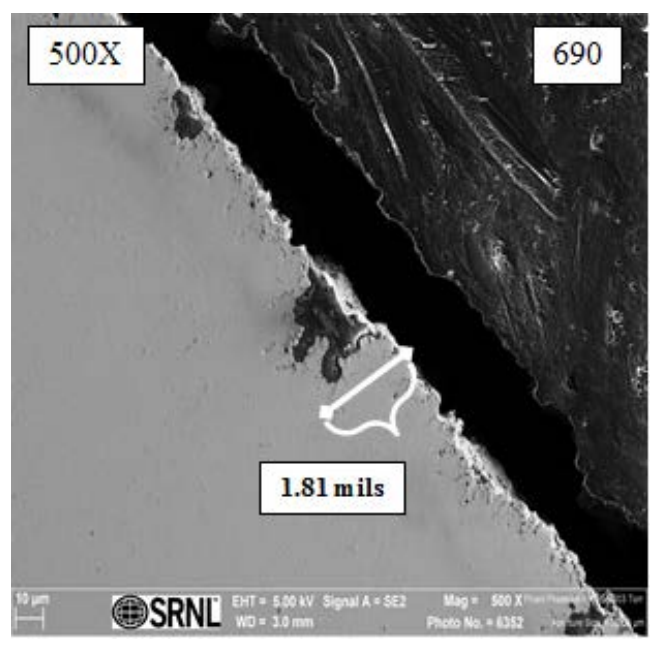

Figure 4-12 SEM secondary electron image showing cracks on the melt line inner diameter surface 

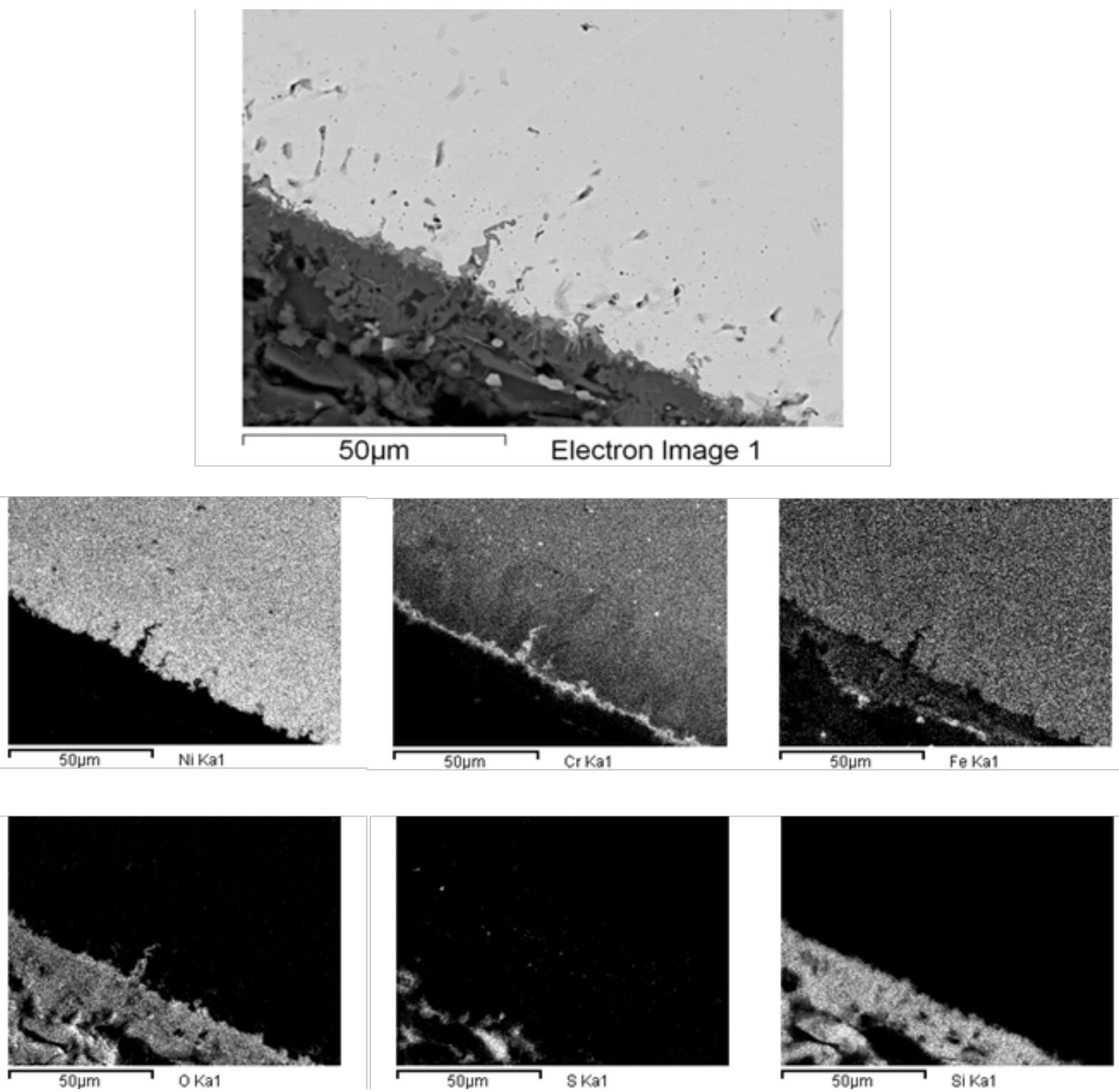

Figure 4-13 Secondary electron and dot map images for various elements from the melt line outer surface. Chromium oxide is evident at the metal/glass interface. Sulfur is also present in the glass but small regions are found in the metal matrix (see arrow). Chromium depletion is evident as shown by slightly darker region at the near-surface region (see arrow)

\subsubsection{Vapor Space}

Intergranular attack was observed on the bubbler outer diameter in the vapor space region to a depth of 1.77 mils (Figure 4-14). No significant pitting was observed on this surface. Chromium oxide was identified on the surface and along the grain boundaries and its presence is consistent with high temperature oxidation (Figure 4-15). Trace amounts of chlorine and sulfur were found in this region. Cracking was observed on the inner diameter but the chromium oxide surface layer was thin and had not penetrated into the metal matrix. The cracks had broadened from their initial as-received condition. A trace amount of sulfur was found in a crack inside the bubbler indicating that vapors volatizing from the glass had entered the bubbler (Figure 4-16). Chlorine was not observed on this surface. 


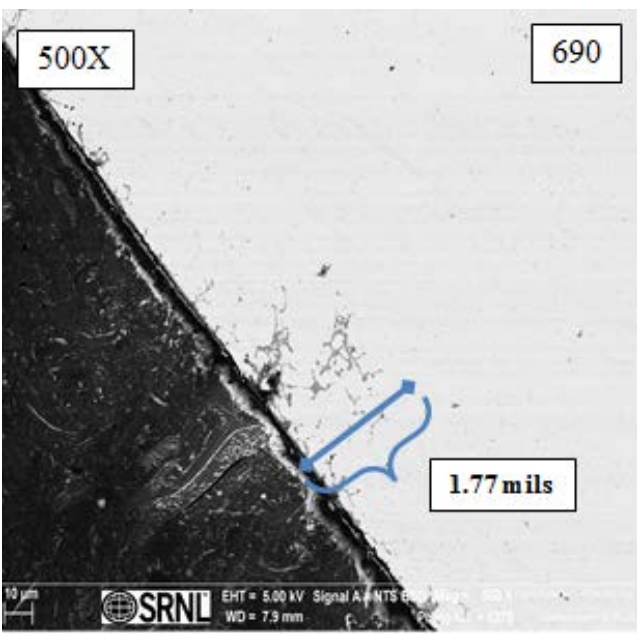

(A)

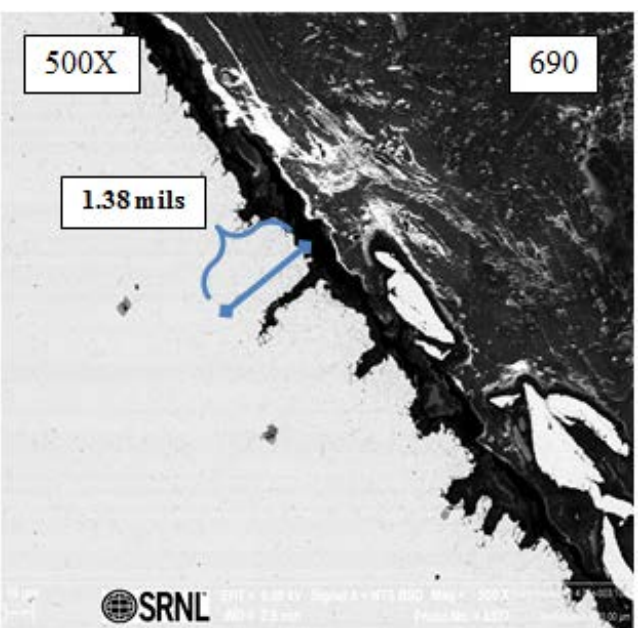

(B)

Figure 4-14 Backscattered images of the outer (A) and inner (B) diameter from the vapor region

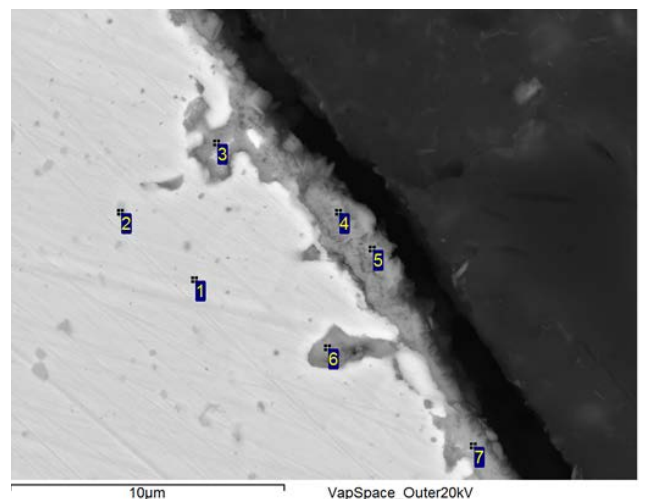

(A)

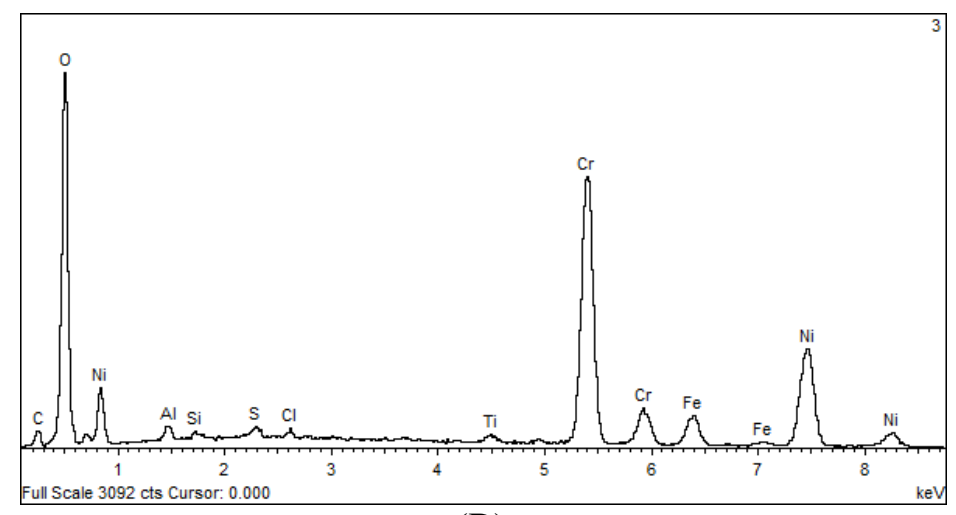

(B)

Figure 4-15 Cracks on outer surface from the vapor space region: (A) Secondary electron image and (B)EDS spectrum showing chromium oxide inside the crack (trace amounts of $\mathrm{Cl}$ and $\mathrm{S}$ were also observed)

\subsubsection{Discussion}

Total degradation (material loss and internal attack) rates in the three regions of the bubbler pipe were very low and consistent when considering the aggressive anions $\mathrm{Cl}^{-}$and $\mathrm{SO}_{4}{ }^{-}$were 300 and $1200 \mathrm{ppm}$, respectively. Material loss was not measurable within the uncertainty of the measuring methods so the degradation rates are based solely on the internal attack measured using the SEM images at 500X magnification. Degradation rates in the melt pool, melt line, and vapor space regions were 0.035, 0.015, and $0.026 \mathrm{in} / \mathrm{yr}$. These results indicate that the glycolic acid is not particularly aggressive to 690 at elevated temperatures. Pitting corrosion was only observed in the melt pool region and it was extremely shallow.

For comparison the total degradation rates of a DWPF melter insert exposed to 1) flowing glass and 2) vapor space conditions were 0.19 and $0.12 \mathrm{in} / \mathrm{yr}$, respectively [24]. Degradation on the glass contact side was attributed to the synergistic effects of oxidation and dynamic molten glass corrosion. Oxidation was the primary degradation mechanism in the vapor space region. No material loss was observed on the vapor space side of the insert. 
Cracking on the inner diameter of the I690 bubbler pipe resulted during the fabrication of the pipe, probably during the gun drilling or piercing processes. Although the surface defects were shallow, they reduce the effective wall thickness and can act as stress concentrators. During the CEF campaign the cracks were observed to broaden somewhat, most likely due to oxidation and/or molten glass corrosion. The corrosive attack was slight because the available oxygen was extremely low and/or the time the relatively benign glass contacted this surface was limited. The presence of these cracks did not affect the results of this test but their presence in actual DWPF melter bubblers could limit their service lives. Therefore, as-received pipe should be metallurgically examined prior to beginning fabrication.

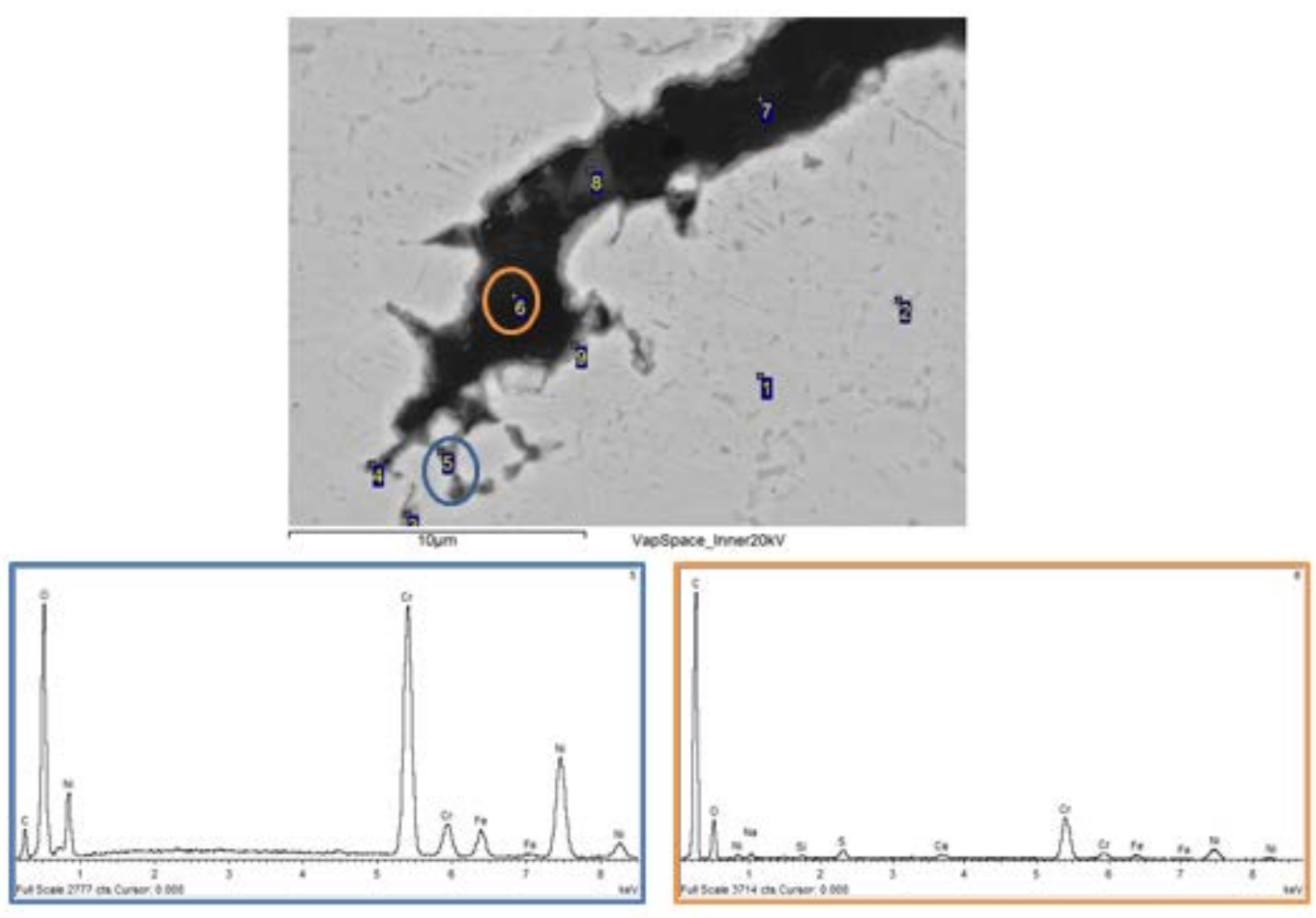

Figure 4-16 Secondary electron image of crack on inner diameter surface from the vapor space region and EDS spectra showing chromium oxide (spot 5) and a trace amount of sulfur inside the crack (spot 6)

\subsection{Monofrax ${ }^{\mathrm{TM}} \mathrm{K}-3$ Coupons}

\subsubsection{Corrosion Mechanisms and Rates in Formic Acid Melter Feeds}

High $\mathrm{Cr}_{2} \mathrm{O}_{3}$ containing Monofrax ${ }^{\mathrm{TM}} \mathrm{K}-3(\mathrm{~K}-3)$ is the refractory that lines the DWPF melter and has been chosen to line other High Level Waste (HLW) and Low Activity Waste melters worldwide. K-3 is tolerant of transition metal oxides in the HLW glass and is composed of highly reduced solid solutions of spinels, i.e. $\left(\mathrm{Mg}_{\mathrm{Fe}} \mathrm{Fe}^{2+}\right)(\mathrm{Al}, \mathrm{Cr})_{2} \mathrm{O}_{3}, \mathrm{FeO}$, and small amounts of $\mathrm{Fe}^{\circ}[25,26]$. The $\mathrm{K}-3$ refractory has been studied extensively at SRNL since 1979 in reducing formic acid flowsheet feeds [27-32]. The testing was primarily performed in crucibles using the ASTM C621 corrosion test. These initial refractory coupon tests in crucibles did not address the effects of feed additives such as formic acid and/or nitric acid on the corrosion of the K-3 refractory because the ASTM C621 test calls for the usage of prefabricated glass. 
The K-3 refractory corrosion rate using the ASTM C621 crucible testing was expressed as two different rates: an "average loss of material" and a "total penetration depth" [30-32]. The two different rates were defined to correspond to two different reaction mechanisms which occurred between the specimen and the molten glass: (1) a "corrosion" reaction mechanism which resulted in a change in the dimensions of the specimen (corresponding to the "average loss of material”) and (2) "selective penetration" of a corrosion front into the material forming a new reaction layer (corresponding to the "total penetration depth"). The "total penetration depth" is, therefore, defined as the "selective penetration” plus the "loss of material."

The corrosion mechanism has been shown to be a depletion in the $\mathrm{Al}_{2} \mathrm{O}_{3}$ and $\mathrm{MgO}$ components of the brick, which leaves the corroded layer containing mostly $\mathrm{Cr}_{2} \mathrm{O}_{3}$. This is in agreement with the findings of Miller and Steggs [34]: the $\mathrm{Al}_{2} \mathrm{O}_{3}$ phase of the $\mathrm{K}-3$ brick is much more vulnerable to solution in glass than the chrome $\left(\mathrm{Cr}_{2} \mathrm{O}_{3}\right)$ phase. In addition, $\mathrm{Fe}_{2} \mathrm{O}_{3}$ and $\mathrm{NiO}$ were found to be enriched in the corrosion layers of the K-3[25, 26]. Silicon appears slightly depleted in the corrosion layers but since the concentration of $\mathrm{SiO}_{2}$ is so low in the refractory it is difficult to be quantitative. The enrichment of the corroded layer in Fe over the amount of Fe in the bulk confirms that iron oxide from the melt is absorbed by the refractory as observed by Maun and Osborn [35] in other chrome refractories and by the K-3 manufacturer [34]. The K-3 contains no $\mathrm{NiO}$ but was shown $[25,26]$ to react with $\mathrm{NiO}$ from the glass forming a Ni-Fe-Cr rich spinel reaction product. This confirms that the K-3 corrosion in DWPF type glasses is a strong function of the nickel oxide and iron oxide content of the glass: $\mathrm{Ni}$ and $\mathrm{Fe}$ in the glass exchange for $\mathrm{Mg}$ and $\mathrm{Al}$ in the refractory [34].

Figure 4-17 shows the growth of crystalline K-3 corrosion products, which volume expand as suggested by Muan and Osborn [35] and shown in References 25 and 26. These crystalline masses protrude from the interface between the corrosion front and the penetration front (SEM in Figure 4-17). The bulk K-3 is rich in $\mathrm{Al}$ and $\mathrm{Cr}$ (region \#1 in Figure 4-17). The area between the penetration front and the corrosion front (region \#2) is defined by the row of protrusions or "tufts" of crystallized material. While region \#2 is still rich in $\mathrm{Al}$ and $\mathrm{Cr}$, species such as $\mathrm{Mn}, \mathrm{Ni}$, and $\mathrm{Fe}$ are diffusing into the refractory from the glass as they comprise major components of this region (Figure 4-17). The region between the corrosion front and the outside of the sample (region \#3) becomes progressively more enriched in $\mathrm{Cr}$ and Fe while becoming depleted in $\mathrm{Mg}$ and $\mathrm{Al}$ toward the outside surface of the sample (region \#4 in Figure 4-17) until there is no refractory matrix left to hold the $\mathrm{Cr}$ and Fe rich "reaction layer" (region \#5 in Figure 4-17). At this point the Fe-Cr-Ni rich "crust" spalls off into the glass melt as $\mathrm{Ni}(\mathrm{Cr}, \mathrm{Fe})_{2} \mathrm{O}_{4}$ spinel (see detached inclusions in region \#5 and region \#6 in Figure 4-17). Figure 4-18 provides an enlargement of the $\mathrm{Ni}(\mathrm{Cr}, \mathrm{Fe})_{2} \mathrm{O}_{4}$ spinel, which is insoluble in the melt, spalling off into the bulk glass where it may continue to adhere to the melter wall or fall to the bottom of the melter depending on melt agitation.

The depletion of the refractory in $\mathrm{Mg}$ is likely responsible for the formation of the refractory corrosion product, krinovite $\left(\mathrm{NaMg}_{2} \mathrm{CrSi}_{3} \mathrm{O}_{10}\right)$ found in the deposits of pilot scale melter floors [33]. The decomposition of high chrome-alumina refractories into magnesium silicates and $\mathrm{MgO} \cdot \mathrm{Cr}_{2} \mathrm{O}_{3}$ is predicted by the known phase equilibria in the $\mathrm{MgO}-\mathrm{Cr}_{2} \mathrm{O}_{3}-\mathrm{SiO}_{2}$ system that has been used to monitor degradation of chrome-alumina refractories in the steel industry [35]. 


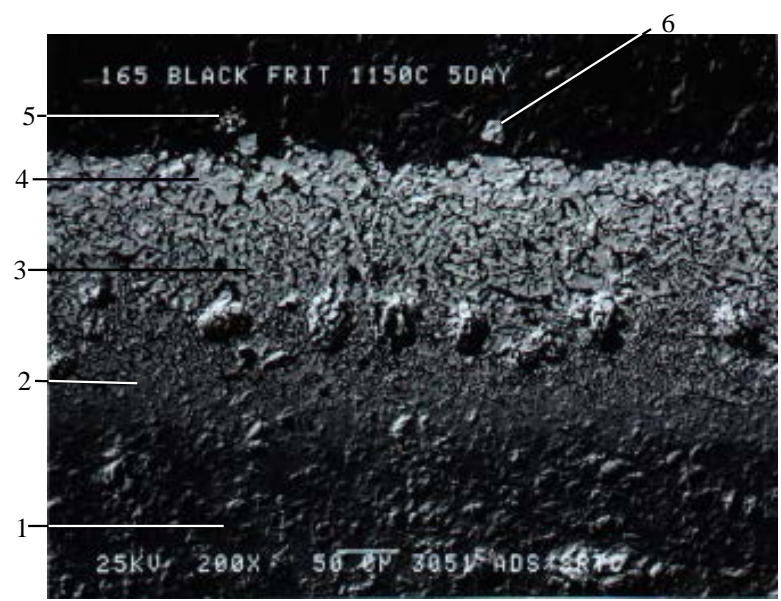

K-3 Corrosion Layer
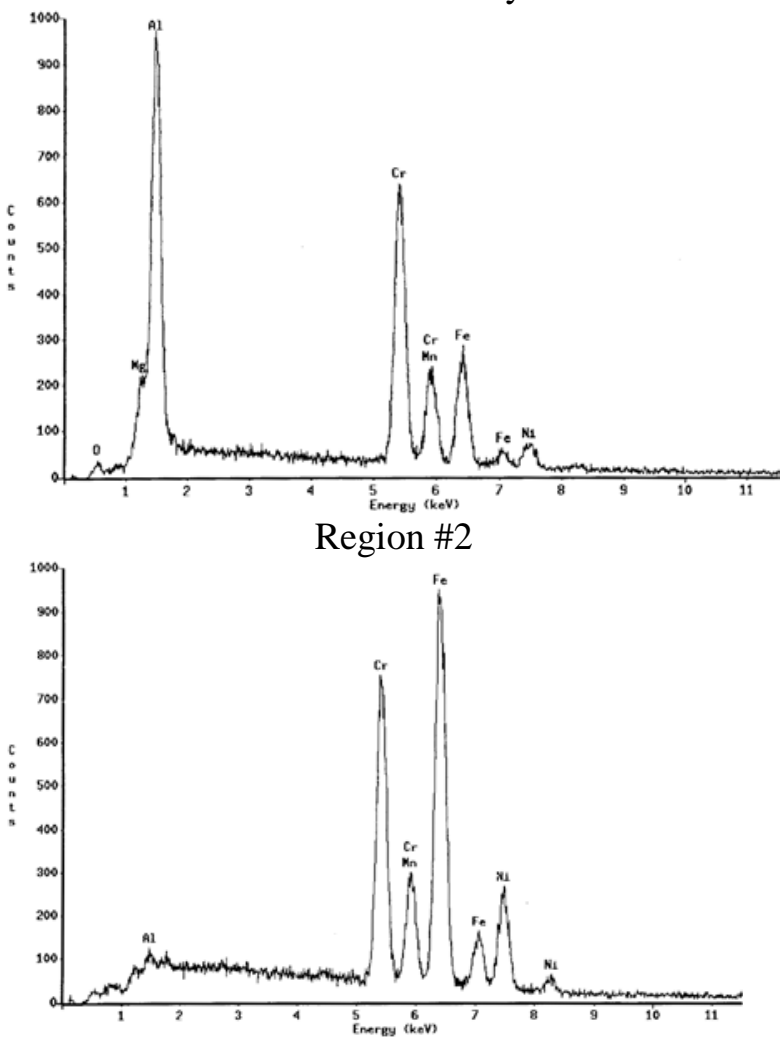

Region \#4

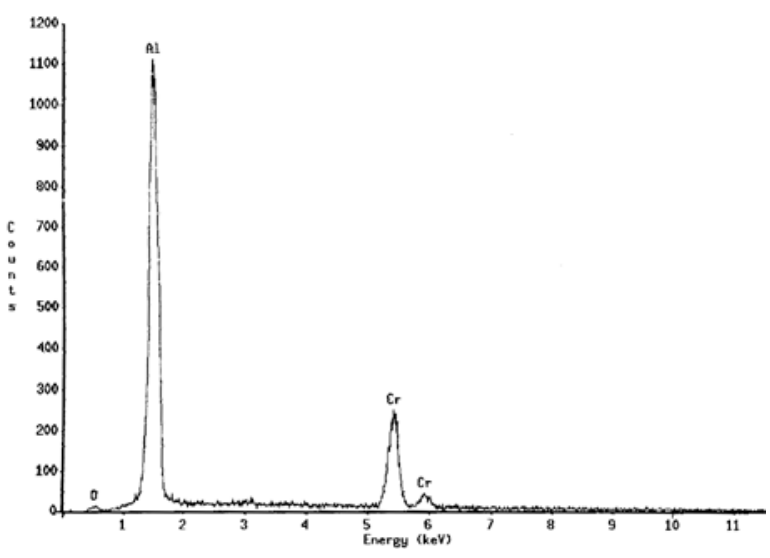

Region \#1
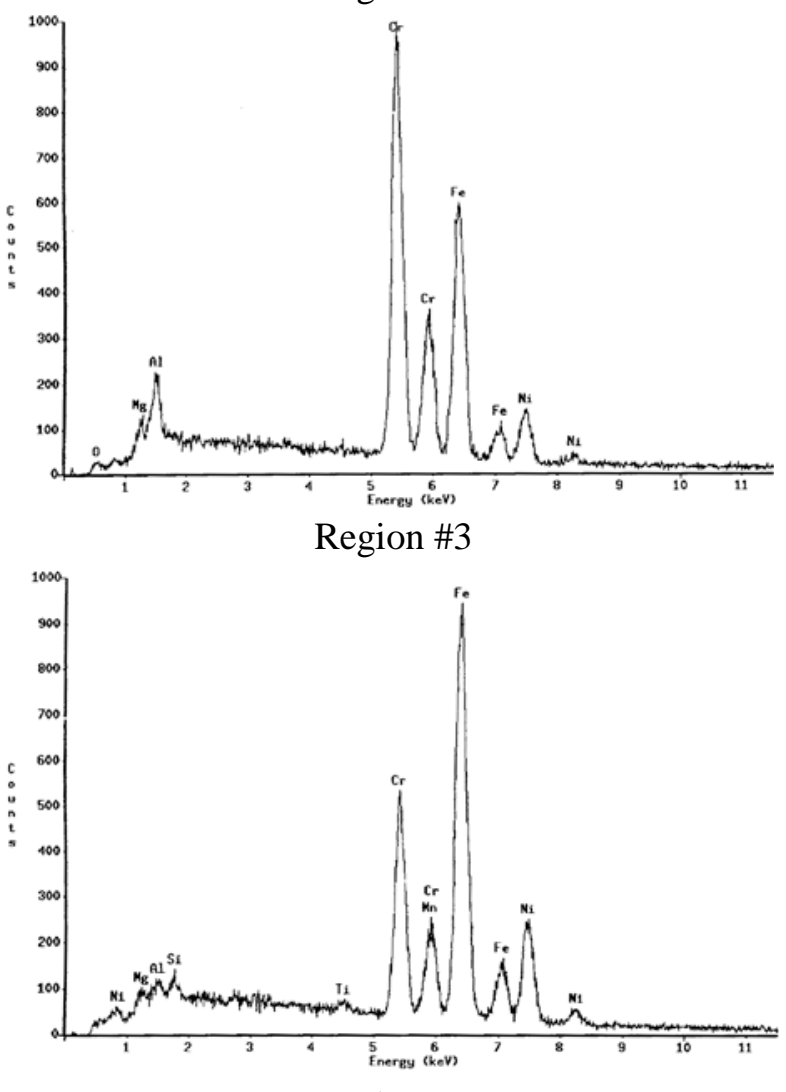

Region \#5

Figure 4-17 K-3 corrosion layer resulting from molten glass: different morphologies of the corrosion layer (regions \#3 and \#4) separated from the penetration layer (regions \#2) and the bulk $\mathrm{K}-3$ (region \#1). The bulk glass is indicated by region \#5. (Note the inclusion (region \#6) that has broken off from the corrosion layer and is dissolving in the glass in Figure 418) 


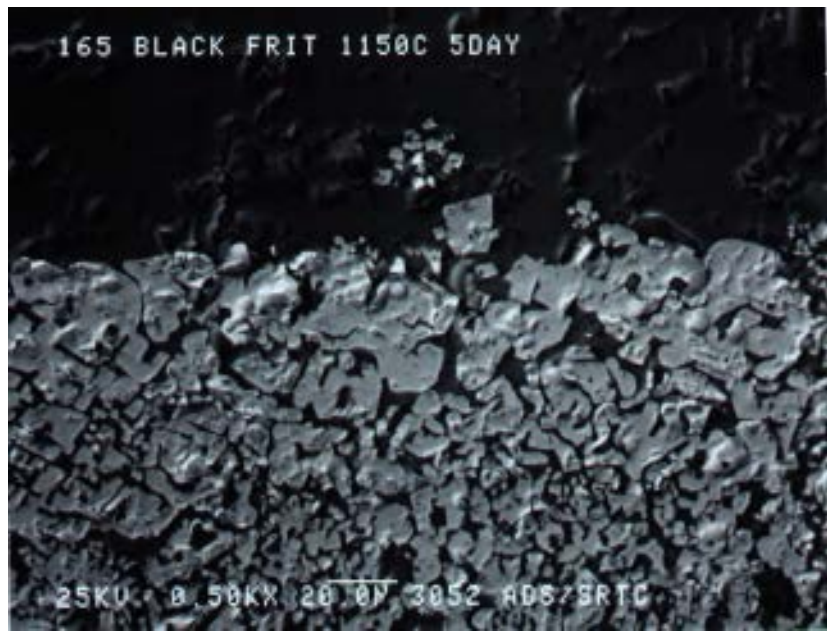

Figure 4-18 An enlarged SEM image of the outer corrosion layer (region \#6 of Figure 4-17) of the K3 refractory showing the breaking away of the Fe-Cr-Mn-Ni rich corrosion layer, which is an insoluble $\mathrm{NiMn}(\mathrm{Fe}, \mathrm{Cr})_{2} \mathrm{O}_{4}$ rich spinel and may be adherent to the melter refractory wall or spall off and fall to the bottom of the melter creating bottom deposits

Therefore, more phases of the K-3 are preferentially dissolved and a crystalline interface is formed during corrosion in molten glass. This is indirect, incongruent, or heterogeneous dissolution as $\mathrm{Ni}$ and $\mathrm{Fe}$ in the waste glass exchange with $\mathrm{Mg}$ and $\mathrm{Al}$ in the refractory. Miller and Steggs [10] determined that the $\mathrm{Al}_{2} \mathrm{O}_{3}$ spinel phase of the K-3 brick was much more vulnerable to dissolution in glass than the chrome $\left(\mathrm{Cr}_{2} \mathrm{O}_{3}\right)$ phase. This result is in agreement with the findings of Muan and Obsorn [11] for the degradation of $\mathrm{Cr}_{2} \mathrm{O}_{3}$ refractories in molten calcium silicate slags. Miller and Steggs also identified the Monofrax ${ }^{\mathrm{TM}} \mathrm{K}-3$ corrosion mechanism in DWPF type glasses as being a strong function of the nickel oxide and iron oxide $\left(\mathrm{Fe}_{2} \mathrm{O}_{3}\right)$ in the glass where $\mathrm{Ni}$ and $\mathrm{Fe}$ in the glass exchange with $\mathrm{Mg}$ and $\mathrm{Al}$ in the refractory. A Ni-Cr-Fe spinel is formed as a K-3 reaction product [36].

In 1998, modified ASTM C621 corrosion testing in crucibles was initiated at SRNL using melter feed instead of pre-reacted glass in order to determine the refractory corrosion rate and mechanisms operable during the feed-to-glass conversion [25, 26, 37]. Testing the refractory coupon during the feed-to-glass conversion exposes the refractory to the oxidizing and reducing species being released during the vitrification process, e.g. $\mathrm{NO}_{3}^{-}, \mathrm{NO}_{2}^{-}, \mathrm{CO}_{2}, \mathrm{CO}, \mathrm{O}_{2}$. This modification was made to evaluate the impact of the oxidizing feed species on the very reduced $\left(\mathrm{Fe}^{2+} / \Sigma \mathrm{Fe}=0.91-0.94\right) \mathrm{K}-3$ because thermodynamic calculations performed by Degterov and Pelton [38] indicated that the solubility limit of $\mathrm{Cr}_{2} \mathrm{O}_{3}$ from $\mathrm{Cr}_{2} \mathrm{O}_{3}-\mathrm{Al}_{2} \mathrm{O}_{3}$ refractories such as $\mathrm{K}-3$ is strongly dependent on the oxygen partial pressure of a melter. Although the example given by these authors is for reduced oxygen partial pressures and the $\mathrm{Cr}^{+2} / \mathrm{Cr}^{+3}$ equilibria, similar ${ }^{4}$ oxygen partial pressure dependency governs the $\mathrm{Cr}^{+3} / \mathrm{Cr}^{+6}$ equilibria under oxidizing conditions [39].

Comparisons of corrosion rate were performed with the modified ASTM C621 procedure for a reducing formic acid flowsheet and a more oxidizing nitric acid flowsheet. Confirmatory corrosion rates were measured on K-3 coupons immersed in oxidizing feed in a 1/100th scale HLW pilot-scale melter [26, 37]. Corrosion rates measured in highly oxidizing (high nitrate) feeds were $1.8-2.8$ times higher than those determined using pre-reacted glass or reduced feeds [26, 37]. Corrosion rates measured using the

$4 \quad$ Free limited access to the $\mathrm{F}^{*} \mathrm{~A} * \mathrm{C} * \mathrm{~T}$ (Facility for the Analysis of Chemical Thermodynamics) thermodynamic software used by these authors is available on the World Wide Web and model calculations involving $\mathrm{Cr}^{+3} / \mathrm{Cr}^{+6}$ equilibria and its oxygen dependency were performed by C.M. Jantzen and A.D. Cozzi of SRNL. 
modified ASTM C621 in reduced feeds were found to be comparable to those measured in ASTM C621 in pre-reacted glass.

The reaction mechanisms were determined for DWPF oxidized and reduced feeds from the product species found on melter autopsy for various pilot scale melters at the SRNL [25, 26, 37]. These reactions indicate that the decomposition of the $\mathrm{K}-3$ not only forms $\mathrm{NiCrFeO}_{4}$ spinel but forms $\mathrm{Mg}$ rich silicates such as krinovite $\left(\mathrm{NaMg}_{2} \mathrm{CrSi}_{3} \mathrm{O}_{10}\right)$ at temperatures of $\sim 1150^{\circ} \mathrm{C}$ which were found upon autopsy. Equation 3, which contains the impact of the oxidizing feeds, is favored over Equation 2 which is written without the $\mathrm{O}_{2}$ from melter denitration reactions.

$$
\begin{aligned}
& \underbrace{6 \mathrm{MgAlCrO}_{4}}_{\text {Major K-3 phase }}+\underbrace{3 \mathrm{Fe}_{2} \mathrm{O}_{3}+6 \mathrm{NiO}+8 \mathrm{SiO}_{2}}_{\text {melt }} \rightarrow \underbrace{6 \mathrm{NiCrFeO}_{4}+6 \mathrm{MgO} \bullet \mathrm{SiO}_{2}+\mathrm{Al}_{6} \mathrm{Si}_{2} \mathrm{O}_{13}}_{\text {observed and predicted chromerefractory products }} \text { \{Equation 2\} } \\
& \Delta G_{f m}(\text { products })-\Delta G_{f m}(\text { reactants })=-1759 \mathrm{KJ} / \text { mole }
\end{aligned}
$$

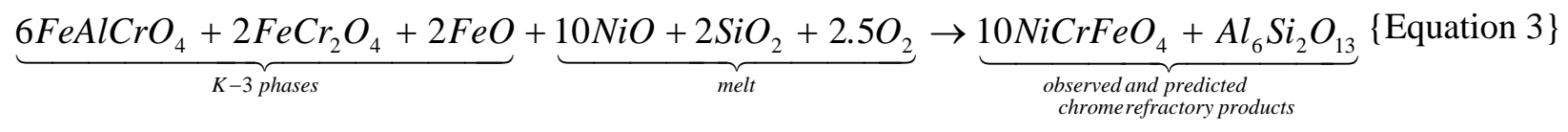

$$
\begin{aligned}
& \Delta G_{f m}(\text { products })-\Delta G_{f m}(\text { reactan } t s)=-3128 K J / \text { mole }
\end{aligned}
$$

Therefore, $\mathrm{Cr}$ enriched $\mathrm{NiFe}_{2} \mathrm{O}_{4}$ spinels form as refractory corrosion products from $\mathrm{K}-3$ and can fall or spall off into the HLW waste glass melt pool. These Cr enriched spinels can agglomerate in the melt pool [25, 26, 37, 38, 40, 41] and ultimately accumulate on the floor of the DWPF melter and/or periodically become entrapped in the riser or pour spout although no accumulations have been seen in pour spout samples taken from the DWPF over the last 20 years [42].

In a melt pool with natural convection, an insoluble $\mathrm{NiFe}_{2} \mathrm{O}_{4}$ spinel corrosion product is formed on the $\mathrm{K}$ 3 that has been found to build up a protective layer along the refractory walls. Spallation and settling of the $\mathrm{NiFe}_{2} \mathrm{O}_{4}$ spinel corrosion product is dependent on melt pool convection/agitation. Based on the refractory corrosion study of Cooper and Nicholson [43], glass flow can cause the outer reaction layer to spall off exposing the penetration layer as the next reaction surface. Therefore, "average loss of material" depths may underestimate refractory corrosion in highly convective, highly stirred, or bubbled melts, while "total penetration" depths may be overly conservative for non-agitated, low-flow environments.

Rankin [44] determined that the "selective penetration" is faster/greater than the "loss of material" corrosion zone in a static or quiescent melter environment. Conversly, the "loss of material" is faster/greater than the "selective penetration" in higher velocity melts as the small eddy currents that form at glass-gas-refractory interfaces, such as at the melt line, increase the "loss of material" corrosion zone. Rankin [32] also noted that higher $\mathrm{Na}_{2} \mathrm{O}$ containing waste glass feeds caused the "total penetration" (loss of material plus selective penetration) depth of the K-3 corrosion to be greater. A similar effect was expected from any alkali in the glass [32].

The "total penetration depths" are preferentially reported as being the most conservative measure of refractory wear. In addition the ratio of the "average loss of material” divided by the "total penetration" depths are given. Average rates and the ratios are reported from various studies in Table 4-1. 
Table 4-1 Monofrax ${ }^{\mathrm{TM}}$ K-3 Corrosion Depths Measured in Non-Bubbled SRNL Melters and by ASTM C621 Modified and Non-Modified Crucible Measurements ${ }^{\S}$

\begin{tabular}{|c|c|c|c|c|c|c|c|c|c|}
\hline $\begin{array}{c}\text { Type of } \\
\text { Measurement }\end{array}$ & $\begin{array}{c}\text { Temp } \\
\left({ }^{\circ} \mathrm{C}\right)\end{array}$ & $\begin{array}{l}\text { Time } \\
\text { (Days) }\end{array}$ & Frit & $\begin{array}{c}\text { Simulated } \\
\text { Waste Type or } \\
\text { Glass }\end{array}$ & $\begin{array}{c}\text { Average } \\
\text { Loss of } \\
\text { Material } \\
\text { (mils) } \\
\text { normalized } \\
\text { to test } \\
\text { duration } \\
\end{array}$ & $\begin{array}{c}\text { Total } \\
\text { Penetra- } \\
\text { tion (mils) } \\
\text { normalized } \\
\text { to test } \\
\text { duration }\end{array}$ & $\begin{array}{l}\text { Ratio of } \\
\text { Loss/ } \\
\text { Penetra- } \\
\text { tion }\end{array}$ & $\begin{array}{c}\mathrm{Na}_{2} \mathrm{O} \text { in } \\
\text { Waste } \\
\text { Glass } \\
(\mathrm{Wt} \%)\end{array}$ & Ref. \\
\hline $\begin{array}{c}\text { Crucible } \\
\text { Melt Line } \\
\text { ASTM } 621 \\
\end{array}$ & 1150 & 7 & 131 & $\begin{array}{l}\text { TDS Average } \\
\text { Waste Glass }\end{array}$ & 0.64 & 1.92 & 0.333 & 12.6 & 32 \\
\hline $\begin{array}{c}\text { Crucible } \\
\text { Melt Line }^{*} \\
\text { ASTM } 621 \\
\end{array}$ & 1150 & 7 & 165 & \multirow{3}{*}{$\begin{array}{l}\text { Black Frit } \\
\text { Glass }\end{array}$} & 0.73 & ND & ND & 11.0 & 45 \\
\hline $\begin{array}{c}\text { Crucible } \\
\text { Melt Line* } \\
\text { ASTM } 621 \\
\end{array}$ & 1150 & 7 & 165 & & 0.23 & ND & ND & 11.0 & 45 \\
\hline $\begin{array}{c}\text { Crucible } \\
\text { Melt Line }^{* *} \\
\text { ASTM } 621\end{array}$ & 1150 & 7 & 165 & & 0.68 & ND & ND & 11.0 & 45 \\
\hline $\begin{array}{l}\text { Crucible - } \\
\text { ASTM C621 }\end{array}$ & 1150 & 5 & 165 & $\begin{array}{c}\text { Black Frit } \\
\text { Glass } \\
\text { (standard for } \\
\text { comparison to } \\
\text { Ref.45) } \\
\end{array}$ & 0.79 & 1.97 & 0.40 & 11.0 & 26 \\
\hline $\begin{array}{c}\text { Crucible - } \\
\text { Sample } \\
\text { (Modified } \\
\text { ASTM C621 }\end{array}$ & 1150 & 5 & 200 & $\begin{array}{c}\text { Tank 51A } \\
\text { Batch 1A } \\
\text { High Nitrate } \\
\text { Feed }\end{array}$ & $\begin{array}{c}\text { Average of } \\
1.57\end{array}$ & $\begin{array}{c}\text { Average } \\
\text { of } 2.49\end{array}$ & $\begin{array}{c}\text { Average } \\
\text { of } 0.63\end{array}$ & 12.7 & 26 \\
\hline $\begin{array}{c}\text { Mini-melter } \\
\text { Melt Line }^{\dagger}\end{array}$ & 1150 & 3 & 200 & \multirow{2}{*}{$\begin{array}{c}\text { Tank 51A } \\
\text { Batch 1A } \\
\text { Lower Nitrate } \\
\text { Feed }\end{array}$} & 2.29 & 2.62 & 0.87 & 12.2 & 26 \\
\hline $\begin{array}{c}\text { Mini-melter } \\
\text { Vapor } \\
\text { Space }^{\dagger}\end{array}$ & 1150 & 3 & 200 & & 0.52 & 0.79 & 0.65 & 12.2 & 26 \\
\hline
\end{tabular}

* As cast K-3 surface

** Ground K-3 surface

† Diamond cut K-3 surface, Corning Engineering Laboratory Services, Corning, NY

$\S$ The comparative corrosion rates for the control standards are shaded as discussed in the table

When the ratios of "loss/total penetration" in Table 4-1 are coupled with the feed and glass compositions in Table 4-2, it can be seen that for corrosion studies in pre-reacted glass which is representative of formic acid feeds [26, 37] in static melt pools that the ratios are between $0.33-0.40$. In oxidized feeds, the ratio is 0.63 in crucible testing and 0.65 in mini-melter testing at high nitrate concentrations, 0.69 and 0.62 molar, respectively. For agitated regions, i.e. near or at the melt line, in oxidized feeds the ratio is even higher, 0.87, at the same molar concentrations of nitrate. Note also that these feeds are simultaneously high in $\mathrm{Na}_{2} \mathrm{O}$ content and nitrate. The significance of these ratios is that the region of "average loss of material" from the corrosion layer is much greater than the total penetration depth, meaning that the refractory will 
wear or corrode faster in oxidizing feeds and even faster in agitated oxidizing feeds. In Section 4.2.2, these rates will be compared to the rates experienced by the K-3 refractory coupon in recent glycolic acid flowsheet testing.

Table 4-2 Feed Compositions Used in Monofrax ${ }^{\mathrm{TM}}$ K-3 Crucible and Mini-melter Tests

\begin{tabular}{|c|c|c|c|c|}
\hline Feed Constituent & $\begin{array}{c}\text { Feed/Glass Used } \\
\text { in Crucible } \\
\text { Studies }\end{array}$ & $\begin{array}{l}\text { Feed/Glass Used } \\
\text { in Mini-melter } \\
\text { Studies - SME } \\
\text { Product 2-11[46] }\end{array}$ & $\begin{array}{c}\text { Feed/Glass Used } \\
\text { in CEF melter } \\
\text { Studies [50] }\end{array}$ & Units \\
\hline & \multicolumn{2}{|c|}{ Tank 51 sludge simulant with Frit 200} & $\begin{array}{l}\text { SB6 Simulant with } \\
\text { Frit } 418\end{array}$ & \\
\hline Waste Loading & 24.8 & 25.6 & 36.0 & \multirow{2}{*}{$\begin{array}{l}\text { wt } \% \text { dry oxide } \\
\text { basis }\end{array}$} \\
\hline Frit Loading & 75.2 & 74.4 & 64.0 & \\
\hline Nitrate & 0.694 & 0.616 & $1.0-1.5$ & \multirow{9}{*}{ Molar } \\
\hline Nitrite & 0.0086 & $<0.002$ & $<0.0028-0.0030$ & \\
\hline Formate & 0.40 & 0.853 & $0.045-0.072$ & \\
\hline Glycol & N/A & N/A & $0.48-0.86$ & \\
\hline Sulfate & $1.69 \times 10^{-3}$ & $1.28 \times 10^{-3}$ & $1.2-2.0 \times 10^{-2}$ & \\
\hline Chloride & $<2.82 \times 10^{-3}$ & $<2.82 \times 10^{-3}$ & $1.0-1.2 \times 10^{-2}$ & \\
\hline Fluoride & $<5.26 \times 10^{-3}$ & $<5.26 \times 10^{-3}$ & $<6.9-7.2 \times 10^{-3}$ & \\
\hline $\mathrm{Na}$ & \multicolumn{2}{|c|}{$1.3-1.6$} & 1.7 & \\
\hline $\mathrm{Fe}$ & \multicolumn{2}{|c|}{$1.7-1.8$} & 0.64 & \\
\hline Melter feed solids & 41 & 45.61 & $42-49$ & \multirow{6}{*}{$\mathrm{Wt} \%$} \\
\hline $\mathrm{Na}_{2} \mathrm{O}$ in Glass & 12.7 & 12.2 & 11.6 & \\
\hline $\mathrm{Fe}_{2} \mathrm{O}_{3}$ in Glass & 12.5 & & 10.8 & \\
\hline $\mathrm{Al}_{2} \mathrm{O}_{3}$ in Glass & 4.3 & & 9.21 & \\
\hline $\mathrm{NiO}$ in Glass & 0.07 & & 1.35 & \\
\hline MnO in Glass & 1.2 & & 3.19 & \\
\hline
\end{tabular}

Average rates measured in various melter studies and the design basis for the refractory wear in DWPF is given in Table 4-3 for comparison. The DWPF design basis was primarily based on the Small Cylindrical Melter (SCM)-2 campaigns (see Table 4-3). Note that the design basis rates do not distinguish an "average loss of material" and a "selective penetration" depth but consider the sum of these two ("total penetration”) measurements as the overall corrosion rate.

\subsubsection{Corrosion Mechanisms and Rates In Glycolic Acid Melter Feeds}

During the recent glycolic acid melter campaigns [50], a coupon of K-3 was cut from a K-3 refractory brick and immersed in the CEF. The coupon was mounted such that the "hot wall" face, i.e. the face of the brick that would be exposed to the melt pool in the DWPF, was on the outside of the cage (Figure 419). The significance of the "hot wall" face of the brick, according to the manufacturer (conversations with Dennis Walrod of the Carborundum Co. in March, 1996), is that the K-3 refractory is a mixture of predominately $\mathrm{FeO}$ and metallic $\mathrm{Fe}^{\circ}$ with only small traces of $\mathrm{Fe}_{2} \mathrm{O}_{3}$. The metallic iron component is used for REDuction/OXidation (REDOX) control during the casting of the refractory as a REDOX buffer in order to keep the oxidation state of the $\mathrm{Cr}$ component of the $\mathrm{K}-3$ as $\mathrm{Cr}^{+3}$, e.g. to promote the formation of $\mathrm{Cr}_{2} \mathrm{O}_{3}$ spinel. According to Carborundum Co., the $\mathrm{Fe}^{\circ}$ component of a refractory brick is about 0.3 volume \% in the outer ("hot wall") face of the refractory, $0.4 \%$ at 1-2 inch depth, $0.5 \%$ at 2-3 inch depth, $0.7 \%$ at 3-4 inch depth, $1.0 \%$ at 4-5 inches, and 1.5\% at 5-6 inch depth. Since the CEF K-3 coupon was 1/2" thick there should be some variation in the $\mathrm{Fe}^{\circ}$ component of the coupon as a function of depth but 
not a large variation. In addition, carbon deposits are more common on the outer edges of a fused cast refractory brick such as the K-3 as they are formed in graphite molds.

Table 4-3 Relative Corrosion Rates of Pilot Scale Melters, Crucible Studies, and DWPF Design Basis

\begin{tabular}{|c|c|c|c|}
\hline Scenario & $\begin{array}{c}\text { Time Melter } \\
\text { Operated } \\
\text { (Years) }\end{array}$ & $\begin{array}{c}\text { Average "loss of } \\
\text { material" } \\
\text { (mils/day) }\end{array}$ & $\begin{array}{c}\text { Maximum } \\
\text { Corrosion Rate } \\
(\text { mils/day)* }\end{array}$ \\
\hline \multicolumn{4}{|l|}{ Oxidized Feeds } \\
\hline Crucibles with oxidized feed $[25,26,37]$ & N/A & \multirow{3}{*}{$\begin{array}{c}1.57 \\
1.41 \\
\text { average }\end{array}$} & N/A \\
\hline 774-A-Melter Pool Coupon [25, 26, 37] & N/A & & N/A \\
\hline 774-A-Melter Vapor Coupon [25, 26, 37] & N/A & & N/A \\
\hline \multicolumn{4}{|l|}{ Formic Acid Feeds } \\
\hline LSFM overall [36] & 2 & 0.50 & N/A \\
\hline LSFM melt line [36] & 2 & 1.00 & N/A \\
\hline IDMS drain area -7 years [47] & 7 & 0.78 & N/A \\
\hline Crucible 165 Black Frit glass [25, 26, 37] & N/A & $0.68-0.79$ & N/A \\
\hline Crucible $131[25,26,37]$ & N/A & 0.64 & N/A \\
\hline \multicolumn{4}{|l|}{ DWPF Design Basis (Formic Acid Feed) } \\
\hline $\begin{array}{l}\text { DWPF Design Basis } \\
\text { (sidewall above melt line, lid, floor) [48, } \\
49]\end{array}$ & N/A & N/A & 3.00 \\
\hline $\begin{array}{l}\text { DWPF Design Basis } \\
\text { (melt line) from SCM Campaign 2 } \\
\text { Maximum Wear 2-3 inches below melt } \\
\text { line applied to 0-4" below melt line in } \\
\text { DWPF }[48,49]\end{array}$ & N/A & N/A & 7.50 \\
\hline $\begin{array}{l}\text { DWPF Design Basis } \\
\text { (wall >4" below melt line) from SCM } \\
\text { Campaign } 2 \text { Walls below melt line [48, } \\
49]\end{array}$ & N/A & N/A & 5.40 \\
\hline
\end{tabular}

*Based on continuous powder feeding of $4.7 \mathrm{lb} / \mathrm{hr}-\mathrm{ft}^{2}$ of melt surface area and a minimum residence time of the melt in the melt pool of 12 hours.

The K-3 refractory coupon was welded inside an I690 cage on an existing bubbler rod (Figure 4-1). The coupon was mounted such that the bottom was only 5" above the bubbler orifice and the top of the coupon was 9" above the bubbler orifice (Figure 4-1). The K-3 refractory coupon remained in the CEF melter for 25 days (600 hours) and the Ar-bubbler was cycled on and off and the temperature was varied (Figure 4-3). The melter was drained to below the level of the bubbler at the end of the CEF glycolic acid campaign. The bubbler and K-3 refractory coupon were removed for evaluation after the melter cooled to room temperature and was disassembled. 


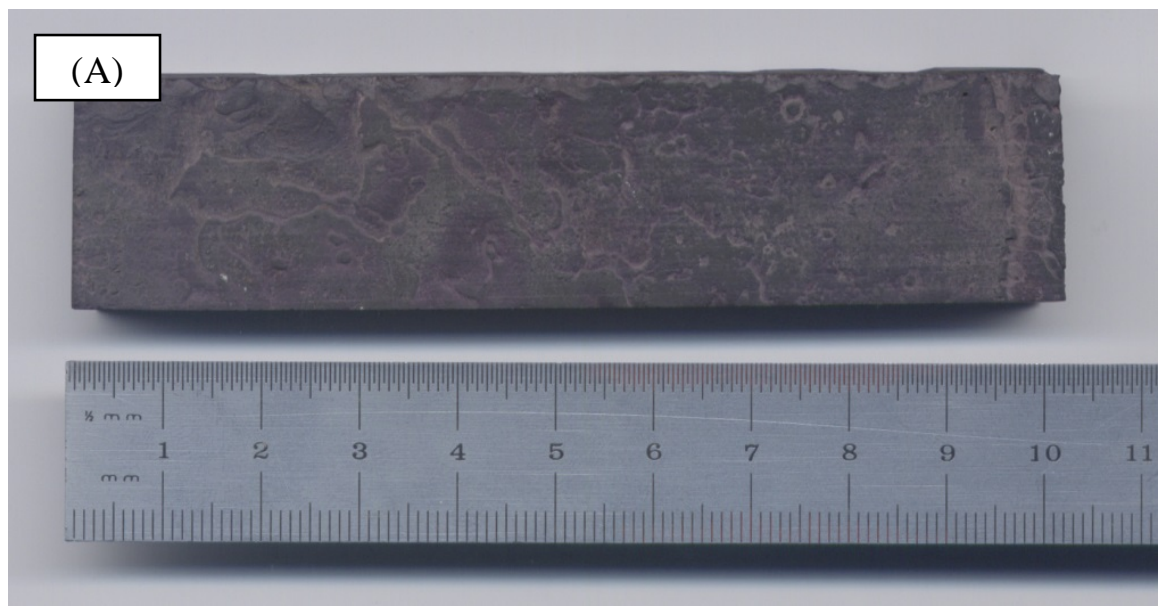

(B)

Figure 4-19 Hot wall side (A) of K-3 refractory brick versus the as cut side (B) of the refractory brick

After the K-3 coupon was pulled from the melter along with the entire bubbler assembly, the portion holding the refractory was cut away from the remaining bubbler rod (Figure 4-20). The top of the refractory coupon, which was $\sim 9$ " from the bubbler orifice, was sectioned and the middle of the coupon, which was 7" from the bubbler orifice, was sectioned for Scanning Electron Microscopy (SEM) analyses in order to maintain the glass-refractory contact zone for study (see dashed axes indicated in Figure 4-20).

The center cut (Ccut) sample was analyzed preferentially to the top cut (Tcut) sample by SEM as the Tcut sample would have been exposed to more turbulence from the bubbler at the discontinuity between the depth of the refractory coupon and the bubbler rod. Both sides of the Ccut sample were examined: the side somewhat protected against the I690 bubbler rod and the side that was exposed to the bubbler and the melt pool.

The following three observations were made based on the analysis of the CEF K-3 refractory and are discussed in the following sections in the order given in this paragraph:

- $\quad$ large regions of cavitation behind the corrosion front were prominent

- $\quad$ chemical corrosion as described in previous studies was observed and the two zones "average loss of material" and "selective penetration" which together form the "total penetration” were observed 
a much deeper corrosion zone that extended below the "total penetration" zone was defined by $\mathrm{Fe}^{\circ}$ and $\mathrm{Fe}^{\circ}-\mathrm{Cr}^{\circ}$ depletion and the formation of an alkali chromate (either $\mathrm{Na}_{2} \mathrm{CrO}_{4}$ or $\mathrm{Na}_{2} \mathrm{Cr}_{2} \mathrm{O}_{7}$ ) in inter-granular cracks and voids.

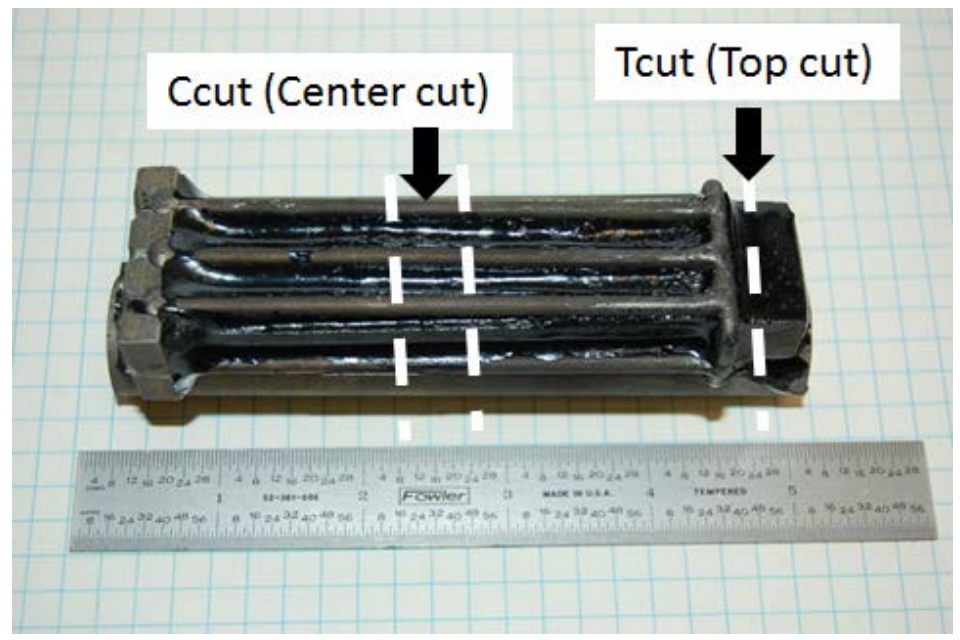

Figure 4-20 K-3 refractory in the I690 cage after removal from the CEF melter (Note the region that was sectioned for SEM analyses to maintain the glass-refractory contact zone)

\subsubsection{Cavitation}

Large regions of cavitation and chemical corrosion were observed in the glass-refractory contact zone with the bubbled glycolic acid feed/melt. Such cavitation has never been observed in the non-bubbled formic acid feed/melt studies. However, refractory corrosion in bubbled formic acid feed/melt studies have never been performed as a comparison. It is believed that the cavitation is due to the proximity of the K-3 refractory coupon to the bubbler orifice since the coupon would have been directly subjected to rising bubbles and turbulence from the bubblers. The cavitation mechanism from bubble impingement is shown schematically in Figure 4-21.

Note also that cavitation of K-3 sidewalls in the M-Area melter were observed at the end of the M-Area melter mission.[51] Due to this operational observation, bubblers are now located further away from the $\mathrm{K}-3$ sidewalls.

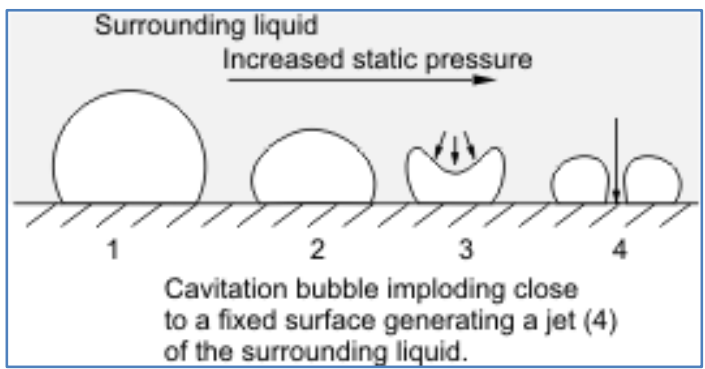

Figure 4-21 Mechanism by which cavitation bubbles implode close to a fixed surface

\subsubsection{General Corrosion}

Irregular cavitation and deep penetrating chemical corrosion makes it impossible to determine an "average" general corrosion rate. This is further complicated by the fact that one has to divide by the 25 days of the CEF campaign to get an "average corrosion" rate as the CEF was bubbled about $1 / 2$ of the campaign and not bubbled the other $1 / 2$ of the campaign. And the bubbling rate was also not constant. 
The open porosity of the K-3 refractory can be seen in Figure 4-22 which are SEM image taken at 50X and 500X magnification. In Figure 4-22 (B) to (D), which were taken in Back Scatter Electron (BSE) mode, the bright (high $\mathrm{Z}$ containing) phase is elemental iron as $\mathrm{Fe}^{\circ}$ which is used to control REDOX in the refractory during fuse casting as discussed above.
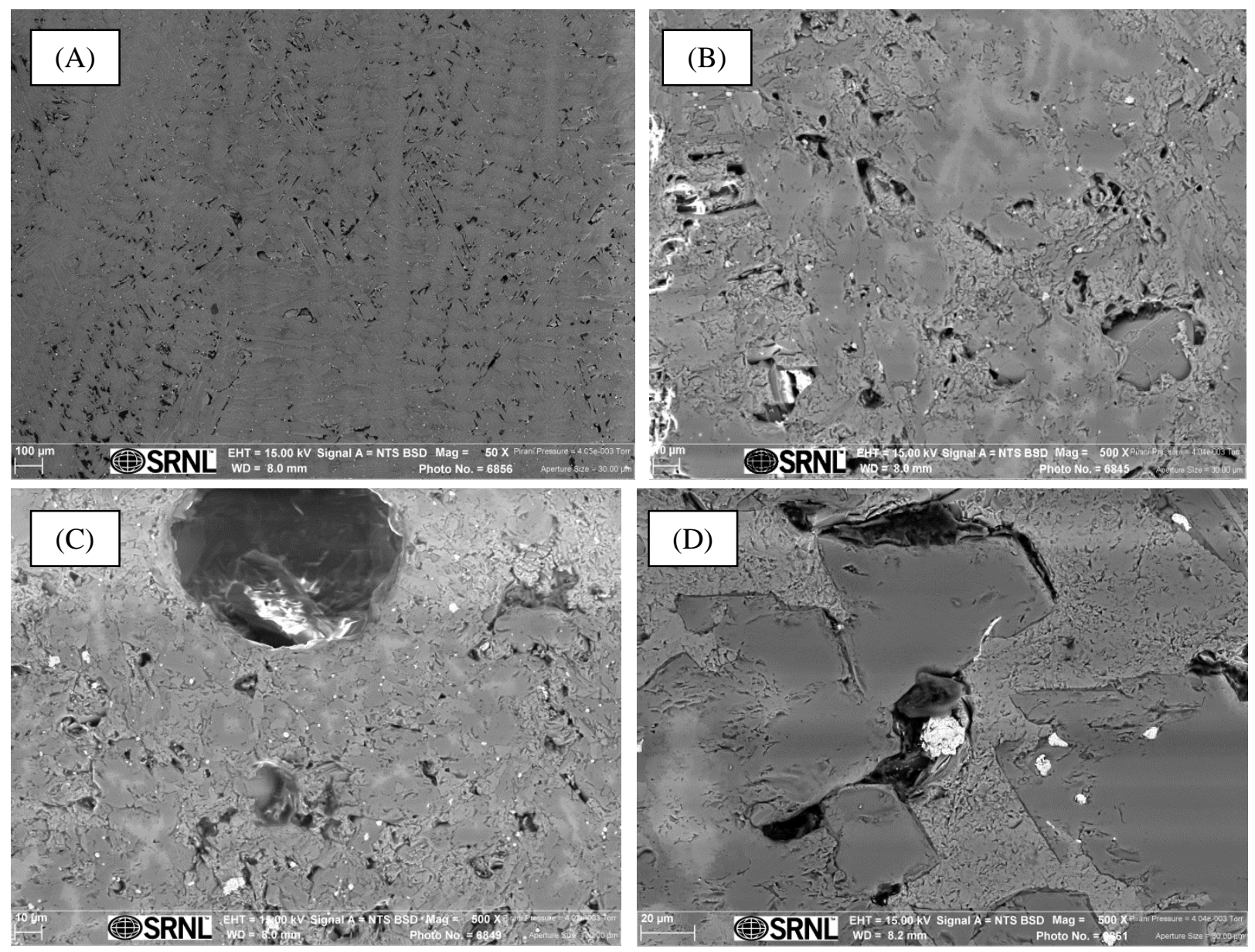

Figure 4-22 Open porosity of the K-3 refractory, as received, at different magnifications: (A) 50x; (B) 500x; (C) 500x; and (D) 500x (Note that in picture (D) the bright "spots" are $\mathrm{Fe}^{\circ}$ which is used in refractory processing.)

Some regions of general corrosion were observed and were similar in appearance to those found with K-3 refractory corrosion in the formic acid flowsheet except that the "average rate of loss" compared to the "total penetration" region was larger, i.e. the ratio of material loss divided by depth of penetration was much larger than any observed in crucible testing (Table 4-1) or in pilot scale studies (Table 4-3) with formic acid. Note that the values in Table 4-1 show smaller ratios for the pre-reacted glass, which is representative of formic acid feeds, than the mini-melter tests with formic acid feeds that were highly oxidizing.

The loss/penetration ratios from the CEF glycolic acid campaign are even larger (Table 4-4) than those observed with oxidized formic acid feeds in Table 4-1which means that the loss of corrosion products is higher in the bubbled glycolic acid feed than in non-bubbled oxidized feeds. In general, oxidized feeds (non-bubbled) are 1.8-2.8X higher than those in non-bubbled reducing formic acid feeds.[25] Therefore, 
it is inconclusive as to whether the proximity to the bubbler or the nitric acid is the cause of the accelerated general corrosion of the K-3 refractory.

Table 4-4 General Corrosion Rate for Monofrax ${ }^{\mathrm{TM}}$ K-3 Refractory in Glycolic Acid

\begin{tabular}{|c|c|c|c|c|c|c|c|c|}
\hline $\begin{array}{c}\text { Type of } \\
\text { Measurement }\end{array}$ & $\begin{array}{c}\text { Temp } \\
\left({ }^{\circ} \mathrm{C}\right)\end{array}$ & $\begin{array}{c}\text { Time } \\
(\text { Days) }\end{array}$ & Frit & $\begin{array}{c}\text { Simulated } \\
\text { Waste Type or } \\
\text { Glass }\end{array}$ & $\begin{array}{c}\text { Average } \\
\text { Loss of } \\
\text { Material } \\
\text { (mils) } \\
\text { normalized } \\
\text { to test } \\
\text { duration }\end{array}$ & $\begin{array}{c}\text { Total } \\
\text { Penetra- } \\
\text { tion (mils) } \\
\text { normalized } \\
\text { to test } \\
\text { duration }\end{array}$ & $\begin{array}{c}\text { Ratio of } \\
\text { Loss/ } \\
\text { Penetra- } \\
\text { tion }\end{array}$ & $\begin{array}{c}\text { Na2O } \\
\text { in Waste } \\
\text { Glass } \\
\text { (Wt\%) }\end{array}$ \\
\hline $\begin{array}{c}\text { CEF Melt Pool } \\
\text { Micrograph } \\
\text { Regions of } \\
\text { Uniform } \\
\text { Corrosion }\end{array}$ & $800-$ & 25 & 418 & SB-6 simulant & 0.39 & 0.59 & 0.66 & 11.6 \\
\hline
\end{tabular}

Frit 418 is composed of $8 \mathrm{wt} \% \mathrm{~B}_{2} \mathrm{O}_{3}, 8 \mathrm{wt} \% \mathrm{Li}_{2} \mathrm{O}, 8 \mathrm{wt} \% \mathrm{Na}_{2} \mathrm{O}$, and $76 \mathrm{wt} \% \mathrm{SiO}_{2}$.

In the regions of general corrosion the mechanism appears to be similar to that identified in previous studies [25, 26, 34, 36, 37]. Side by side comparison of a region of uniform corrosion of the K-3 refractory in the glycolic acid feed is given in Figure 4-23 (A) while the refractory in ASTM C621 testing in pre-reacted glass (black frit) is given in Figure 4-23 (B).
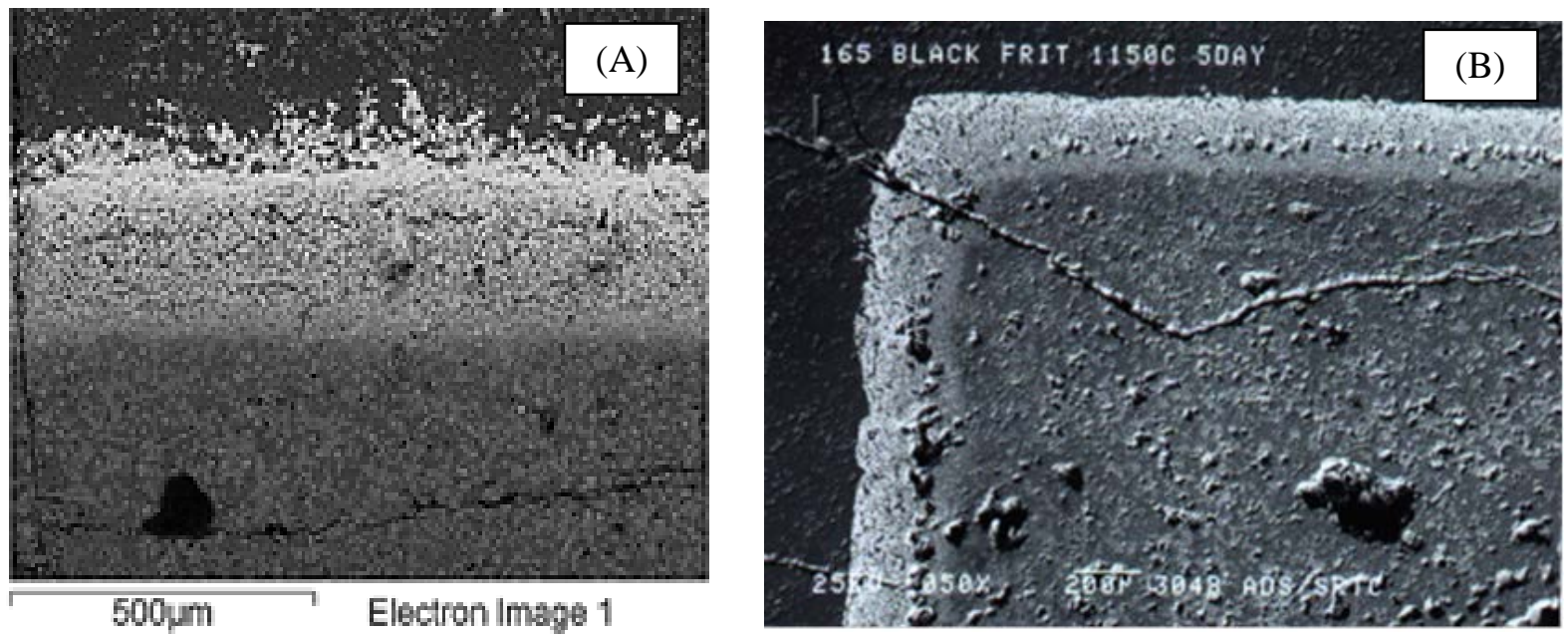

Figure 4-23 (A) SEM of the K-3 refractory corrosion coupon immersed in glass made from glycolic acid feed from frit 418 for 25 days at $\sim 1150^{\circ} \mathrm{C}$; (B) SEM of the K-3 refractory corrosion coupon immersed in glass composed of DWPF black frit glass 165 for 5 days at $1150^{\circ} \mathrm{C}$ (Note the thick corrosion layer which is composed of two layers separated by a row of circular bubble-like precipitates. The outer layer is more porous and is designated the corrosion or "average loss" layer. The inner layer is termed the penetration layer)

The region of bursting expansion that defines the boundary between the "loss of material region" and the "penetration depth" region are seen in both sides of Figure 4-23. The scales of the micrographs are different, with the glycolic acid image being 2X lower magnification than the ASTM C621 pre-reacted glass micrograph. In Figures 4-24 through 4-26, elemental x-ray maps associated with the K-3 tested in the glycolic acid feed/glass is shown on the top of each figure while the elemental x-ray maps for the same elements are shown in the bottom of each figure for the pre-reacted glass tested in crucibles. The 
same enrichment in $\mathrm{Cr}, \mathrm{Fe}$, and $\mathrm{Ni}$ are seen in the corrosion layers and the same depletion in $\mathrm{Al}, \mathrm{Mg}$, and Si are seen in the corrosion layers of the K-3 refractory.

The mechanism of K-3 refractory corrosion in glycolic acid flowsheet is, therefore, the same as the mechanism in the formic acid flowsheet except that the "average loss of material" is greater than the "total penetration" in the glycolic acid feed (compare values in Tables 4-1 and 4-4). It should be noted that this is hard to determine as the "average loss of material varies widely when measured.
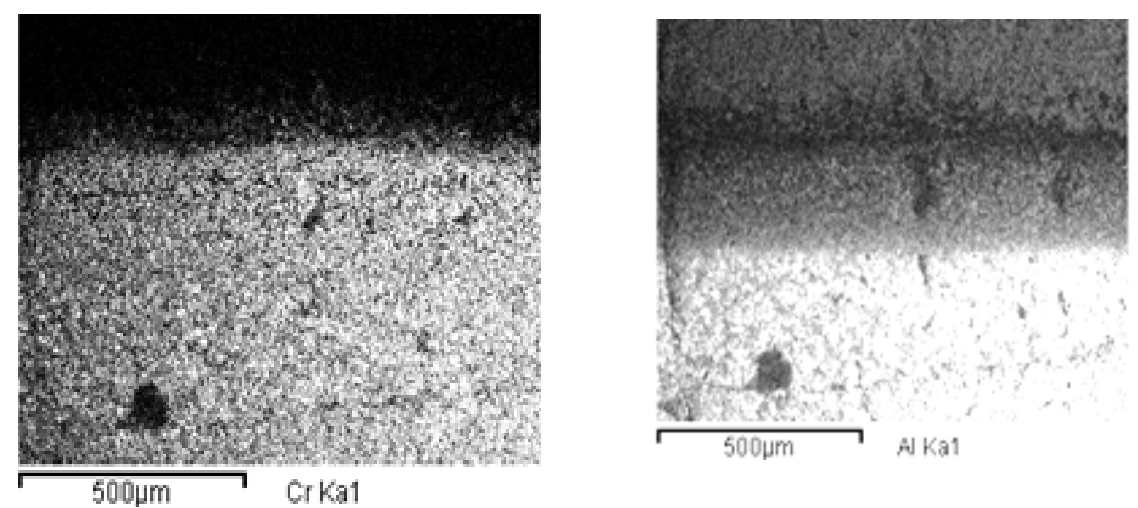

K-3 side in Glycolic Acid Feed/Glass

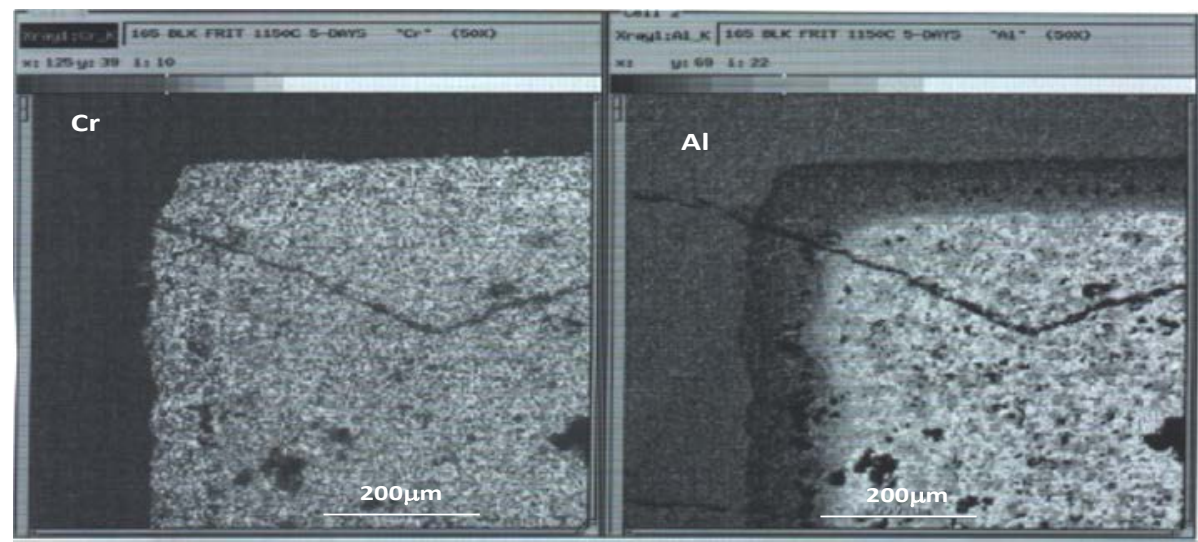

K-3 corner in Black Frit 165 prefabricated glass.

Figure 4-24 X-ray maps showing enrichment (brighter outer rim image) in $\mathrm{Cr}$ in the corrosion layer corresponding to Figure 4-23 and showing depletion (darker outer rim image) in $\mathrm{Al}$ in the corrosion layer 


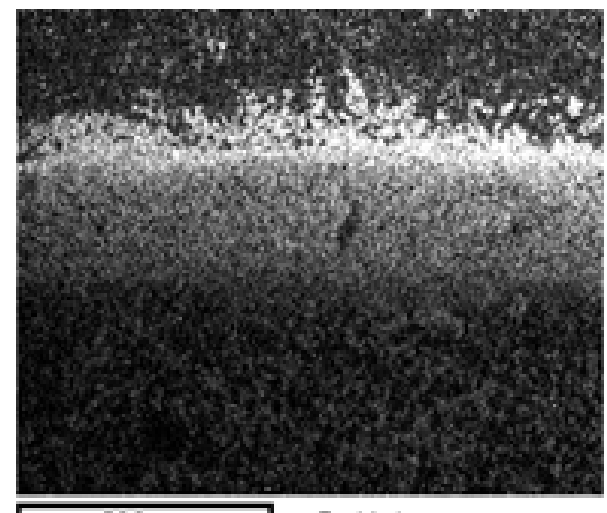

$\overline{500 \mu \mathrm{m}} \mathrm{FeKa1}$

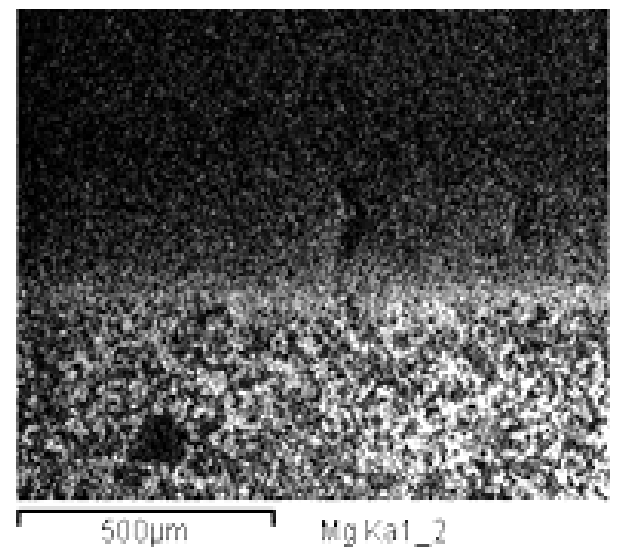

$500 \mu \mathrm{m}$

K-3 side in Glycolic Acid Feed/Glass

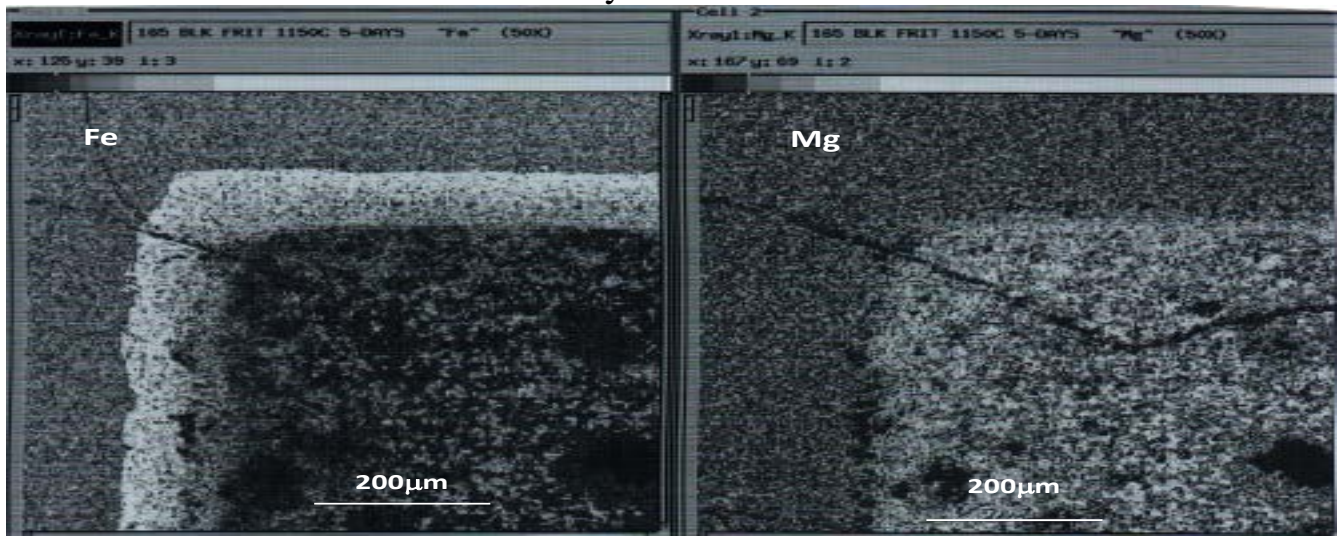

K-3 corner in Black Frit 165 prefabricated glass.

Figure 4-25 X-ray maps showing enrichment (brighter outer rim image) in Fe in the corrosion layer corresponding to Figure 4-23 and showing depletion (darker outer rim image) in $\mathrm{Mg}$ in the corrosion layer

\subsubsection{Selective Corrosion of $\mathrm{Fe}^{\circ}$ and $\mathrm{Fe}^{\circ}-\mathrm{Cr}^{\circ}$}

Figure 4-27 (A) shows the dual corrosion layers in the CEF glycolic acid feed relative to that seen in prereacted glass and previous studies. In the glycolic acid sample the "loss of material" zone appears larger than the penetration zone as described in the previous section. This can be caused by proximity to the bubblers, but is also characteristic of high nitrate feed versus the reducing flowsheet feeds, i.e compare the ratios of the two zones in Table 4-1 and Table 4-4

Figure 4-27 (A) also shows how cracks and voids along the crack axis are filled with glass and/or a secondary phase. Figure 4-27 (B) is an enlargement of one of the voids along the larger crack shown in Figure 4-27 (A) and it is obvious that the void is filled with a secondary phase. It is also of note that there is a lack of $\mathrm{Fe}^{\circ}$ (bright spots) in the hot wall of the refractory which appears to be lower than the amount anticipated at this depth from discussions with Carborundum in 1996. Most of the cracks and cavitation voids penetrate well below the corrosion front as shown in Figure 4-28. In Figure 4-28, the "average loss of material” is scattered out into the surrounding glass by $>500 \mu \mathrm{m}$. 


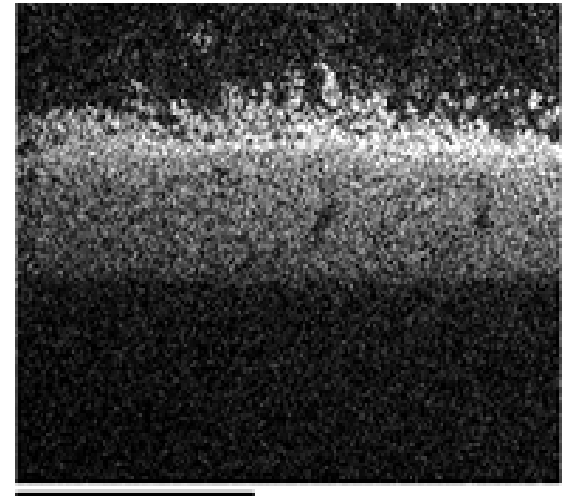

$500 \mu \mathrm{m}$

NiKa1

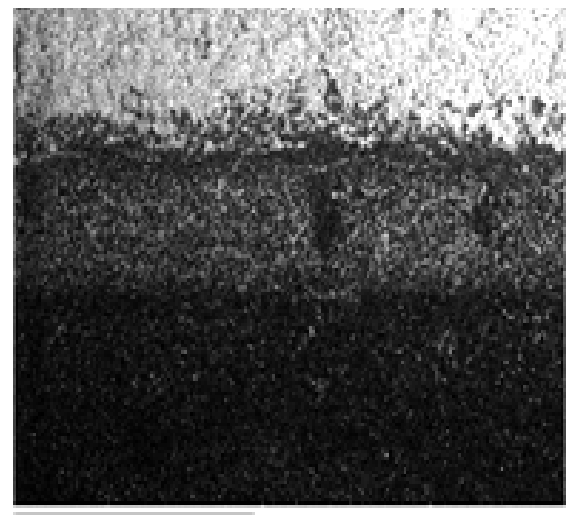

$500 \mathrm{~m}$

K-3 side in Glycolic Acid Feed/Glass

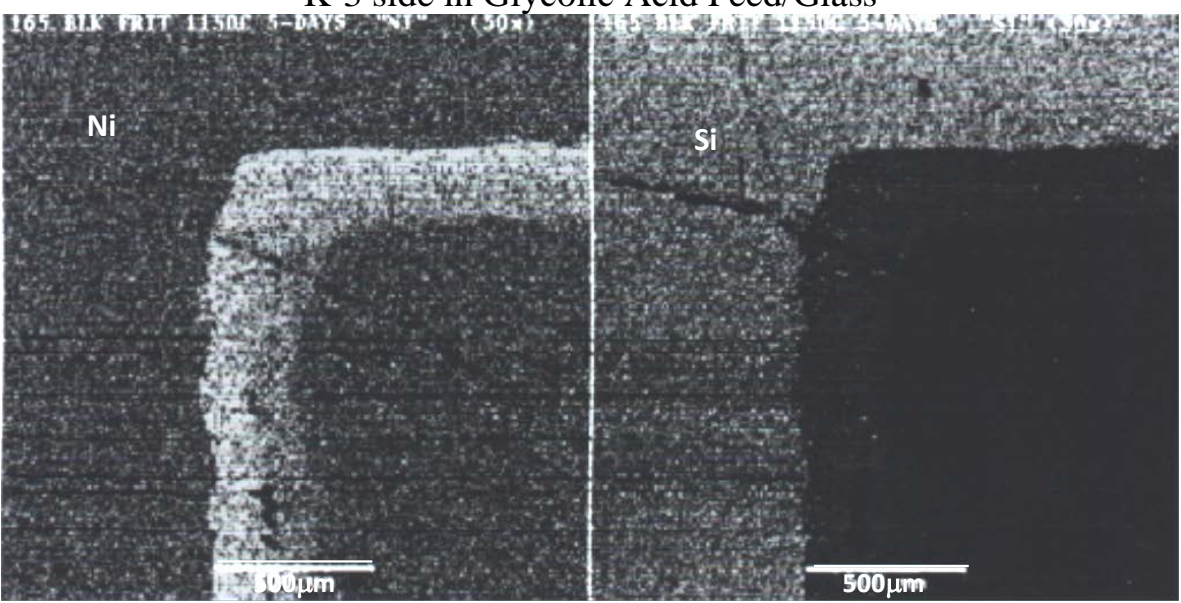

K-3 corner in Black Frit 165 prefabricated glass.

Figure 4-26 X-ray maps showing enrichment (brighter outer rim image) in Ni in the corrosion layer corresponding to Figure 4-23 and showing depletion (darker outer rim image) in Si in the corrosion layer
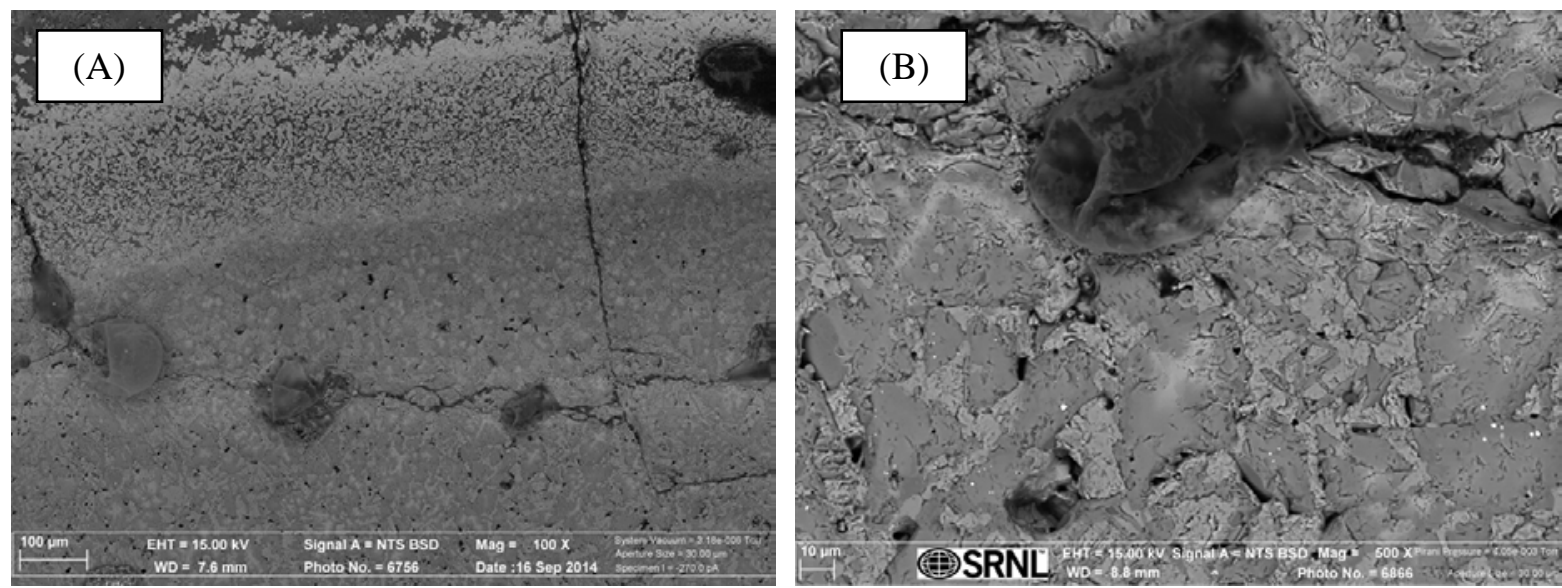

Figure 4-27

Hot-face of the K-3 refractory block that was in contact with the glass:

(A) 100x and (B) $500 \mathrm{x}$ 

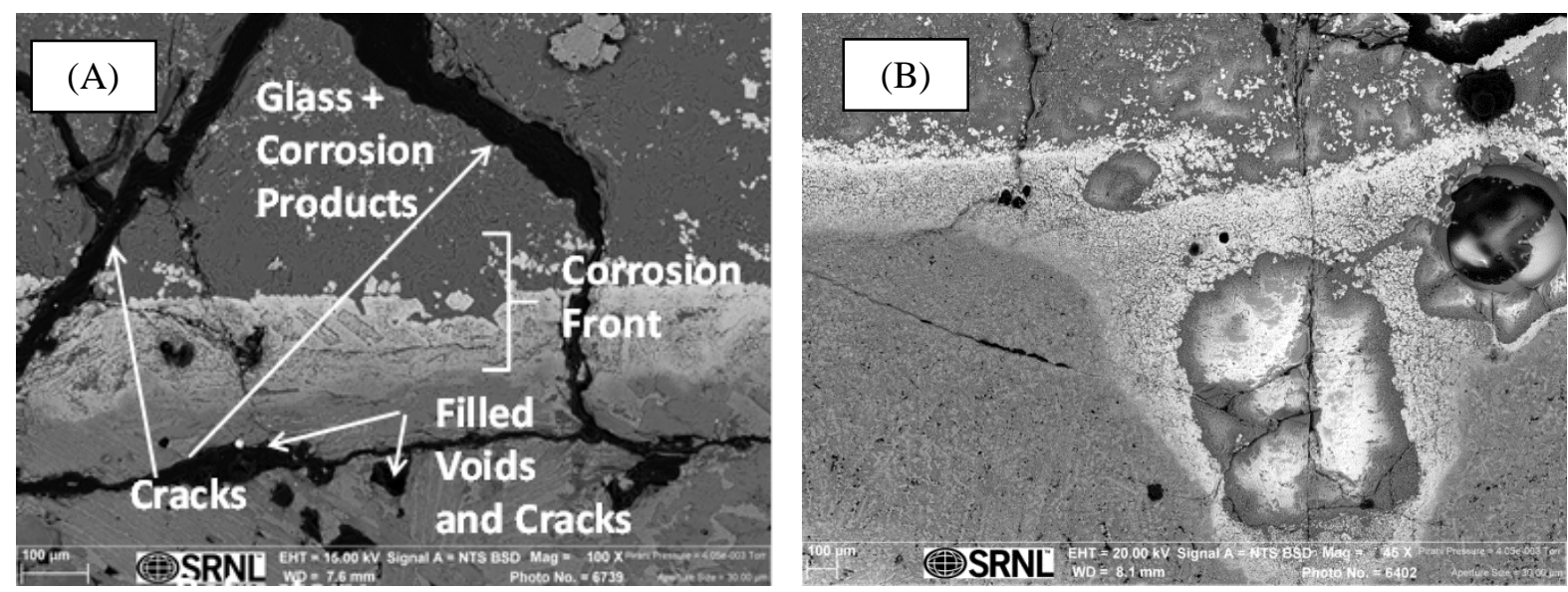

Figure 4-28 Cracks, voids and cavitations in the K-3 refractory (Note how deeply the cracks and cavitation penetrate into the refractory): (A) 100x and (B) 40x
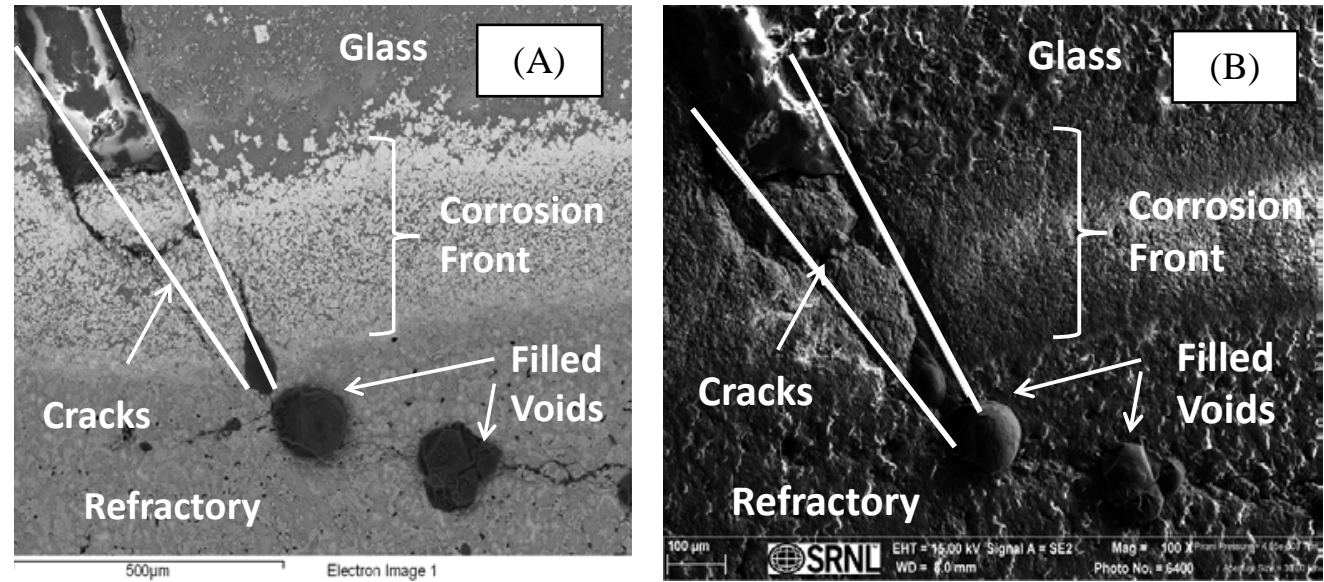

Figure 4-29 Cracks and filled voids along the cracks that are deep below the corrosion front in back scattered electron (A) image and secondary electron (B) image, where the secondary electron image shows that the voids are filled with a secondary phase

In Figure 4-29, a backscattered electron image (Figure 4-29 (A)) compared to a secondary electron image (Figure 4-29 (B)) and shows that the "voids" are filled with a secondary phase. Semi-quantitative analysis by EDS of the different regions is given in Figure 4-30. The upper most elongated blob between the two cracks is filled with epoxy mounting medium used to mount the sample for SEM analyses. Figure 4-30 (A) and (B) are the EDS spectra of the filled void material, upper and lower voids respectively. Figure 4-30 (C) and (D) d are the EDS spectra of the glass and refractory, respectively. From Figure 4-30 (A) and (B), it is obvious that the voids are filled with a sodium enriched chromate material, likely $\mathrm{Na}_{2} \mathrm{CrO}_{4}$ or $\mathrm{Na}_{2} \mathrm{Cr}_{2} \mathrm{O}_{7}$. 

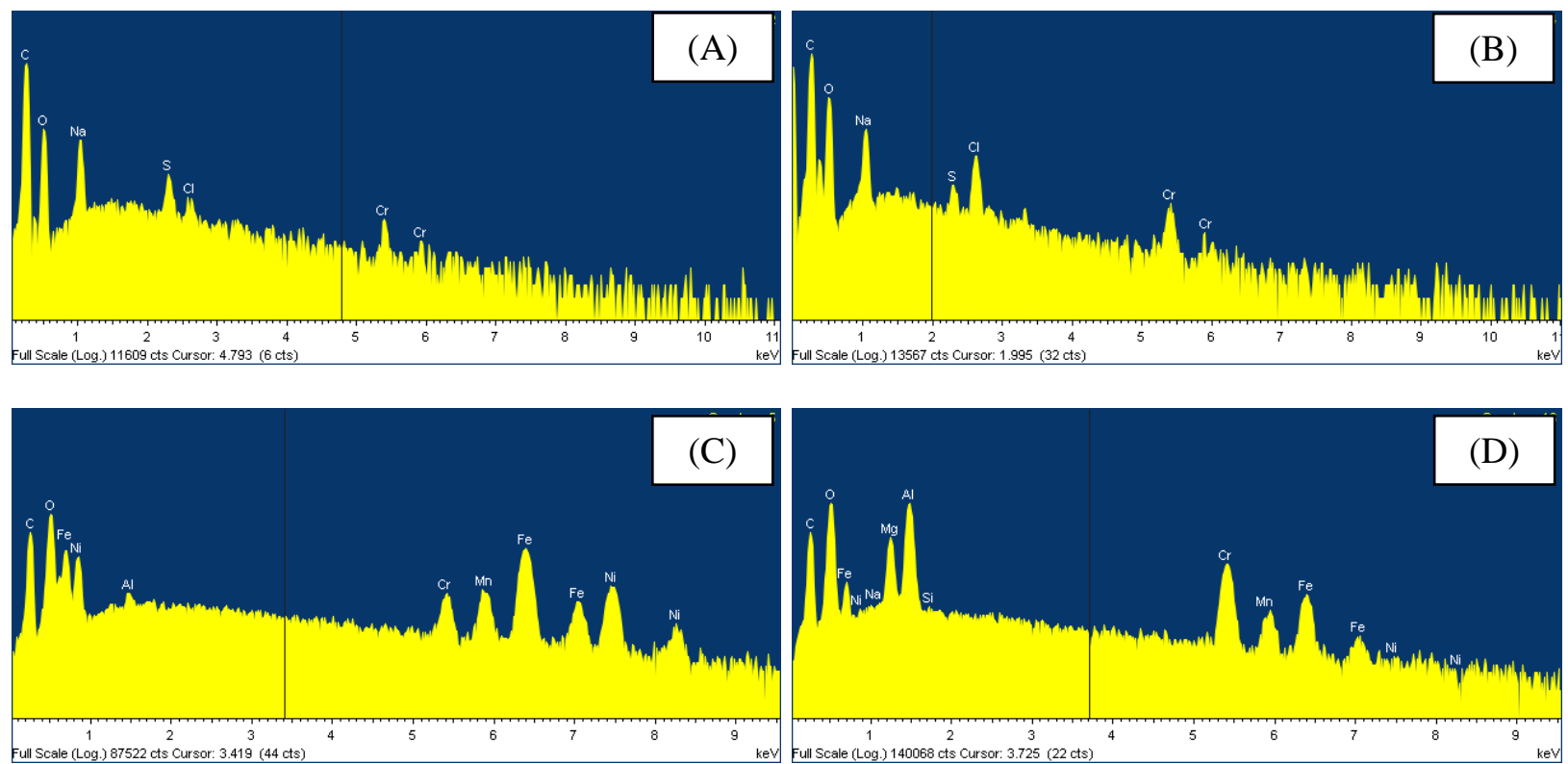

Figure 4-30

Results of EDS analyses of the different phases in Figure 4-29: (A) upper void; (B) lower void; (C) glass; and (D) refractory

The composition of the filled voids helps elucidate the selective phase corrosion attack mechanism. In work performed at SRNL in the past and recently published [26, 37], a molten interstitial phase which appears to be a solid solution of $\mathrm{Fe}^{\circ}-\mathrm{Cr}^{\circ}$ was found to meander along the grain boundaries of the $\mathrm{K}-3$ spinel phases. This solid solution of $\mathrm{Fe}^{\circ}-\mathrm{Cr}^{\circ}$ was once molten allowing it to follow the grain boundaries of the other oxide phases (see Figure 4-31). Note how the solid solution is narrow in between two adjoining phases and widens in the region of multi-granular junctions. In addition spheres of $\mathrm{Fe}^{\circ}$ were identified, likely the $\mathrm{Fe}^{\circ}$ added during processing of the $\mathrm{K}-3$ for REDOX control (Figure 4-32). The K-3 is highly reduced, $\mathrm{Fe}^{2+} / \Sigma \mathrm{Fe}=0.917-0.939$ [25].

The CEF glycolic campaign which was supposed to be reducing had nitrate concentrations in the 1.0-1.5 molar range (Table 4-2). This is twice as much nitrate than used in any formic acid flowsheet. Iron metal, $\mathrm{Fe}^{\circ}$, is especially susceptible to attack by nitric acid forming iron nitrate species and NO by the following reaction:

$$
2 \mathrm{Fe}^{\circ}+8 \mathrm{HNO}_{3} \rightarrow 2 \mathrm{Fe}\left(\mathrm{NO}_{3}\right)_{3}+2 \mathrm{NO}+4 \mathrm{H}_{2} \mathrm{O}
$$

A similar reaction could be written with $\mathrm{NaNO}_{3}$ as the $\mathrm{Fe}^{\circ}$ is unstable under oxidizing conditions in the feed or the melt (excess $\mathrm{O}_{2}$ in the melt). According to the table of reduction/oxidation half reactions from Reference 26 reproduced here as Table 4-5, nitrate is a stronger oxidizing agent than iron is a reductant but nitrate is not as strong an oxidizer as $\mathrm{Cr}$ is a reductant, so $\mathrm{Fe}^{\circ}$ would get preferentially oxidized/dissolved compared to $\mathrm{Cr}^{\circ}$. 


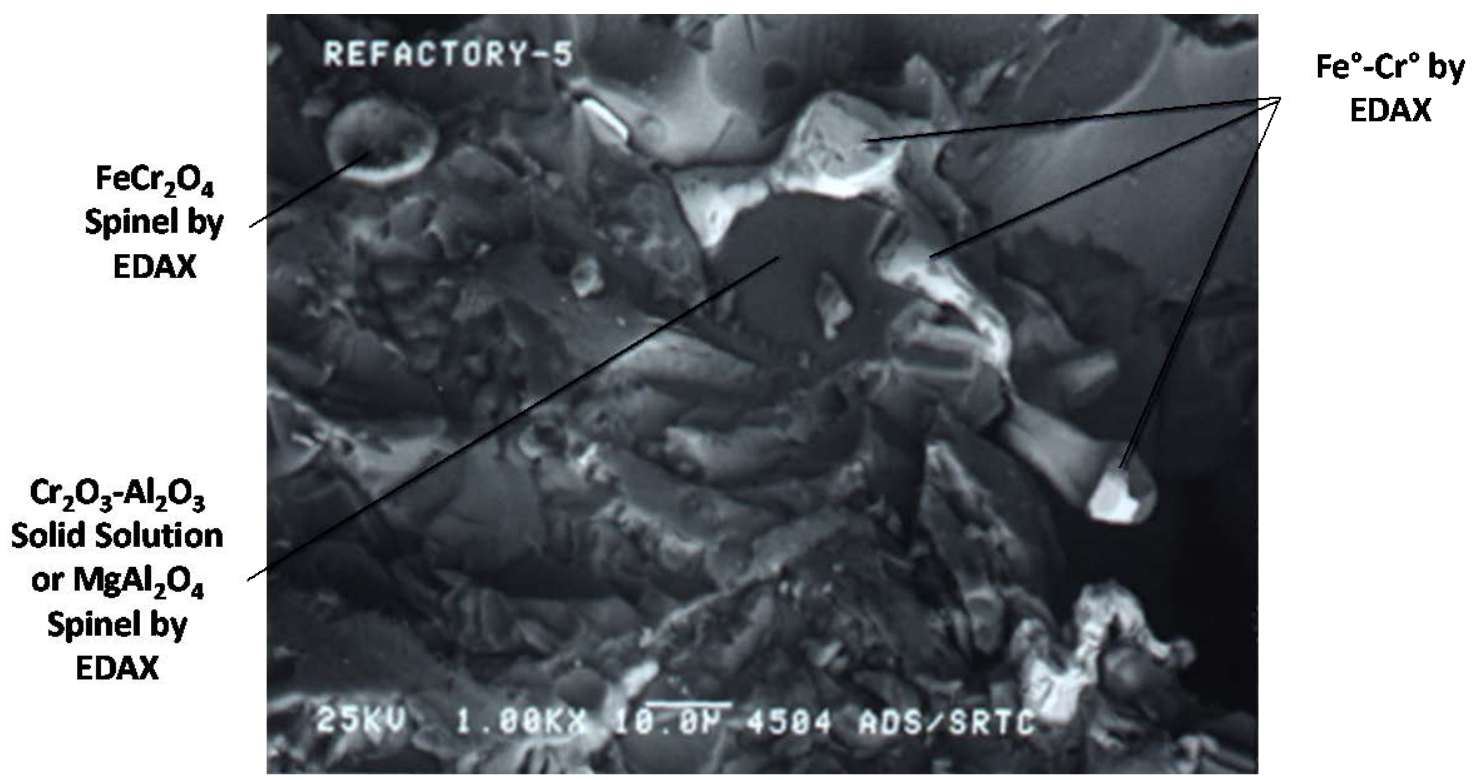

Figure 4-31 Phase morphology and composition of Monofrax ${ }^{\mathrm{TM}} \mathrm{K}-3$ refractory (Note fluid looking $\mathrm{Fe}^{\circ}-\mathrm{Cr}^{\circ}$ metallic phase that follows the grain boundaries of the other oxide phases) [26]

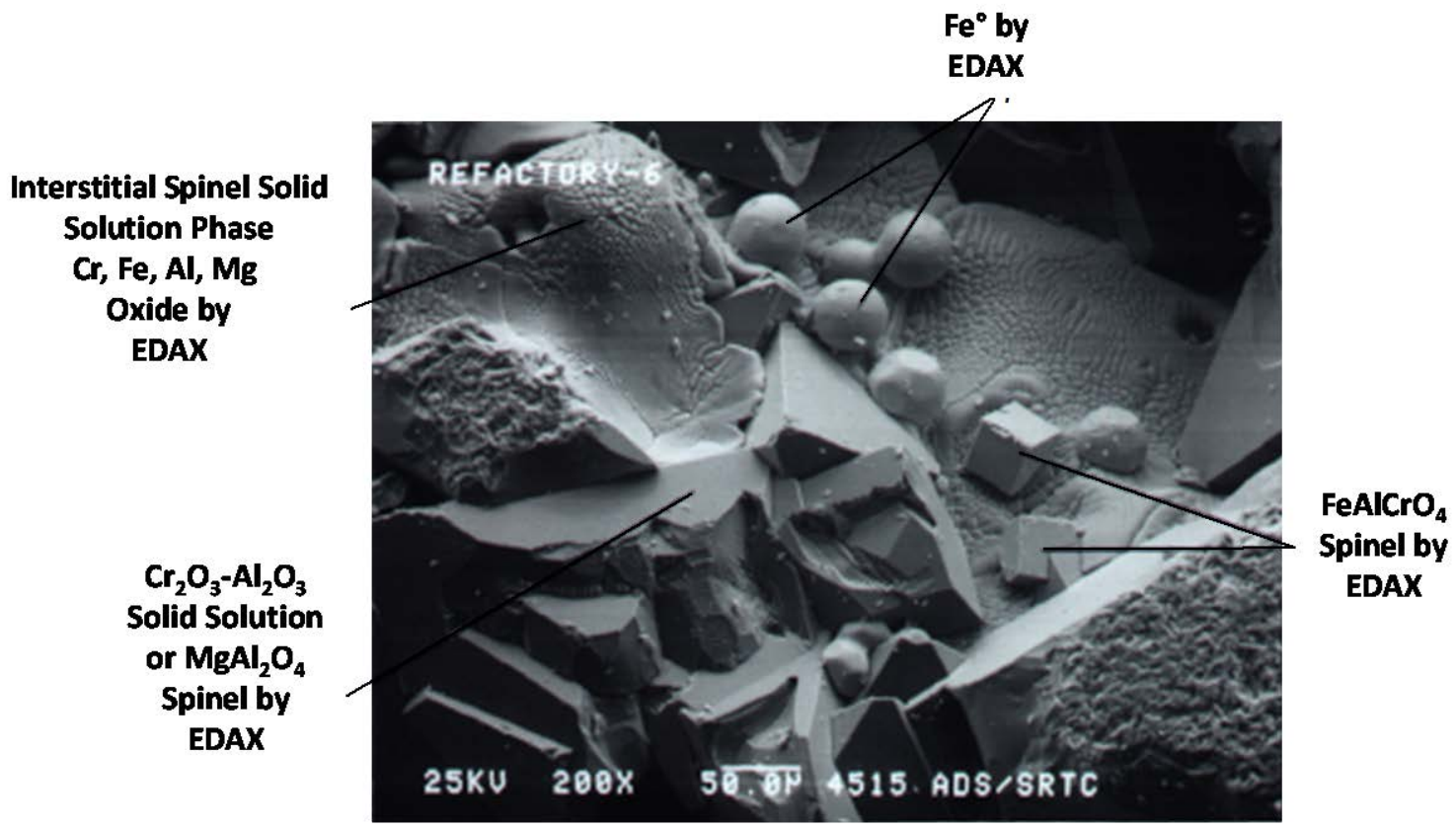

Figure 4-32 Phase morphology and composition of Monofrax ${ }^{\mathrm{TM}}$ K-3 refractory showing a spherical $\mathrm{Fe}^{\circ}$ component [26]

Therefore, the selective corrosion attack mechanism is most likely the selective attack of the $\mathrm{Fe}^{\circ}$ (spherical) and the $\mathrm{Fe}^{\circ}$ portion of the $\mathrm{Fe}^{\circ}-\mathrm{Cr}^{\circ}$ solid solution so that the $\mathrm{Cr}^{\circ}$ is oxidized to $\mathrm{Cr}^{+6}$ and couples with the alkali in the glass to form sodium chromate deposits in what appear to be voids. However, careful examination of Figure 4-31 indicates that the $\mathrm{Fe}^{\circ}-\mathrm{Cr}^{\circ}$ solid solution has wider and narrower regions along the grain boundaries of the oxide phases in the refractory and that the cracks and voids may represent these different grain boundaries, i.e. double grain boundaries that appear as cracks and triple or quadruple grain boundaries that appear as voids. 
Table 4-5 Reduction/Oxidation Half Reactions [26]

\begin{tabular}{|l|c|}
\hline Pertinent “Half” Reactions & $\mathrm{E}^{\circ}$ Potential, (Volts) \\
\hline REDUCTIONS & +1.77 \\
\hline $\mathrm{N}_{2} \mathrm{O}+2 \mathrm{H}^{+}+2 \mathrm{e}^{-} \rightarrow \mathrm{N}_{2}+\mathrm{H}_{2} \mathrm{O}$ & +1.24 \\
\hline $\mathrm{NO}_{3}{ }^{-}+6 \mathrm{H}^{+}+5 \mathrm{e}^{-} \rightarrow 0.5 \mathrm{~N}_{2}+3 \mathrm{H}_{2} \mathrm{O}$ & \\
\hline OXIDATIONS & -1.33 \\
\hline $2 \mathrm{Cr}^{+3}+7 \mathrm{H}_{2} \mathrm{O} \rightarrow \mathrm{Cr}_{2}^{+6} \mathrm{O}_{7}^{-2}+14 \mathrm{H}^{+}+6 \mathrm{e}^{-}$ & -1.21 \\
\hline $\mathrm{Mn}^{+2}+2 \mathrm{H}_{2} \mathrm{O} \rightarrow \mathrm{Mn}^{+4} \mathrm{O}_{2}+4 \mathrm{H}^{+}+2 \mathrm{e}^{-}$ & -1.68 \\
\hline $\mathrm{Mn}^{+4} \mathrm{O}_{2}+2 \mathrm{H}_{2} \mathrm{O} \rightarrow \mathrm{Mn}^{+7} \mathrm{O}_{4}^{-}+4 \mathrm{H}^{+}+3 \mathrm{e}^{-}$ & -1.93 \\
\hline $\mathrm{Ni}^{+2}+2 \mathrm{H}_{2} \mathrm{O} \rightarrow \mathrm{Ni}^{+4} \mathrm{O}_{2}+4 \mathrm{H}^{+}+2 \mathrm{e}^{-}$ & -0.77 \\
\hline $\mathrm{Fe}^{+2} \rightarrow \mathrm{Fe}^{+3}+\mathrm{e}^{-}$ & \\
\hline
\end{tabular}

To help substantiate the selective attack of nitrates on the metallic species in the K-3 refractory, a semiquantative SEM analysis of phases that are different densities was performed as a function of depth from the back and front surfaces of the refractory coupon. The SEM can "sense" phases of different density and calculate how much area in a given micrograph is occupied by each of the phases (Figure 4-33). The smallest area is believed to represents the $\mathrm{Fe}^{\circ}$ densest phase. If $4 \mathrm{~mm}$ in depth (158 mils) is representative of the inner portion of the refractory, then it is obvious that there is a region of $\mathrm{Fe}^{\circ}$ depletion from the surface to a depth of $\sim 3 \mathrm{~mm}$ (118 mils or 4.7 mils/day) or more. This $\mathrm{Fe}^{\circ}$ depletion zone weakens the refractory and allows glass to penetrate along the cracks and cause corrosion fronts along the cracks and around interior nodules in the refractory as shown in Figure 4-33 (B). The depth of the $\mathrm{Fe}^{\circ}$ is larger than the general corrosion for the glycolic acid campaign, and the general corrosion is greater than any observed in formic acid flowsheets with or without a significant amount of nitric acid. The $\mathrm{Fe}^{\circ}$ is believed to be caused by the attack of the excess nitric acid in the glycolic feeds and not the glycolic acid itself.

The general corrosion mechanism of K-3 refractory in the glycolic acid flowsheet is, therefore, the same as the mechanism in the formic acid flowsheet except for the following:

1. Extensive cracking and cavitation has not been observed in the formic acid flowsheet since no bubbled melter or crucible studies have been performed on the formic acid flowsheet with a Monofrax ${ }^{\mathrm{TM}} \mathrm{K}-3$ coupon.

2. Selective $\mathrm{Fe}^{\circ}$ depletion to a depth that far exceeds any corrosion rates previously measured in formic acid flowsheets even with fairly oxidized formic acid feeds since no bubbled melter or crucible studies have been performed on the formic acid flowsheet with a K-3 coupon.

3. The $\mathrm{Fe}^{\circ}$ depletion appears to create the "cracks" and "voids" which appears to be a selective attack of the $\mathrm{Fe}^{\circ}$ used in the refractory processing and attack of the $\mathrm{Fe}^{\circ}$ component of the $\mathrm{Fe}^{\circ}-\mathrm{Cr}^{\circ}$ solid solution that forms along grain boundaries in the refractory during processing

4. General corrosion exceeds that in oxidized feeds, i.e. the "average loss of material" is much greater than the selective penetration depth of glass into the refractory. This does not include the $\mathrm{Fe}^{\circ}$ depletion zone.

5. The cavitation is likely due to the proximity of the refractory coupon to the bubbler orifice.

If another CEF run is performed, K-3 coupons should not be located directly above the bubbler. The bubbler caused cavitation of the K-3 coupon directly behind the corrosion front making interpretation of the corrosion rates inconclusive. Additionally K-3 coupon should only be submerged during steady state 
operation, even if only for 48 hours. Immersion during the entire CEF run complicates the measurement of an "average" corrosion rate since the coupon exposed to variable temperatures and variable bubbling rates.

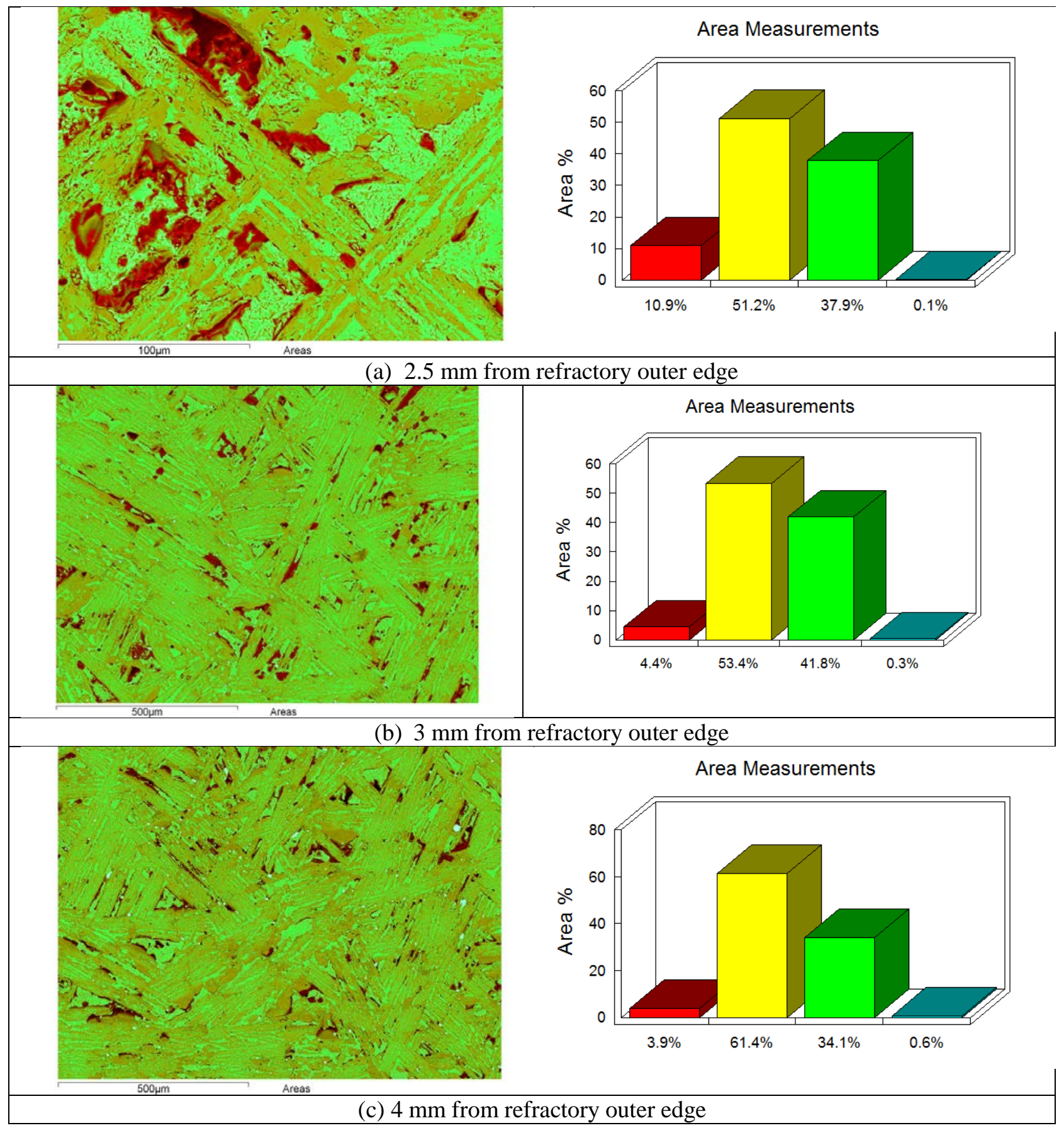

Figure 4-33 Phase contrast SEM with semi-quantative area measurements of each phase. The smallest phase indicated by the darkest color on the far right of each graph represents metallic Fe 


\subsection{Recommendations}

Additional testing or tasks are recommended to establish the temperature and glycolic acid/glycolate anion limits for acceptable corrosion performance of the DWPF and downstream SSCs, especially those susceptible to localized corrosion.

The expected performance of the materials of construction within the CPC, specifically C276, Ultimet and Stellite at boiling temperatures, is questionable due to the susceptibility to localized corrosion identified during this testing. Since the glycolate anion concentration is at the highest in the CPC for the whole HLW processing system, determining operating limits where localized corrosion is not a concern is stressed. Additional testing for these materials is recommended to better understand the limits of these results and identify conditions for acceptable performance in service.

These proposed tests would include performing electrochemical testing with formic acid based SRAT/SME supernates, which would provide a correlation between accelerated electrochemical test results and observed performance of components within the CPC and with glycolic acid based SRAT/SME supernates at levels of aggressive species (chloride, sulfate and mercury) where localized corrosion does not occur. Similar simulants would be used in hot-wall tests to verify that localized corrosion also does not occur under heat transfer conditions. Finally, a coupon immersion test is recommended to verify that the accelerated results of the electrochemical test occur with time during an extended exposure in the coupon test.

Additional testing was also recommended for other materials where the presence of the glycolate anion impacted test results. These tests are recommended to better identify the temperature and glycolic acid limits for acceptable performance of the materials of construction, especially those susceptible to localized corrosion.

1. The electrochemical test for 304L in unaltered $70 \%$ glycolic acid indicated possible localized corrosion, although these results are not conclusive for the effect of 304L at actual service temperatures. Additional testing is recommended for 304L at the actual service temperature of the formic acid feed vessels and piping. Coupon immersion test at service temperatures would provide necessary data if pitting will occur over an extended exposure in 304L that is contact with glycolic acid in the DWPF.

2. Hot-wall testing for C276, Ultimet, G30 and G3 all showed susceptibility to crevice corrosion and for some materials pitting. All the test solutions contained the glycolate anion. Additional hotwall testing is recommended in solutions made without glycolate. Procedures would be altered so as to change the solution during the testing so that changes in the small volume of test solution, which would not be expected in service, do not impact test results.

3. During the CEF campaign, cracks on the inner diameter of the bubble pipe, which was used as a test coupon, were observed to broaden, possibly due to oxidation and molten glass corrosion. This cracking resulted during the fabrication of the pipe and will reduce the effective wall thickness as well as act as stress concentrators. The presence of these cracks did not affect the results of this test but their presence in actual DWPF melter bubblers could limit their service lives. Therefore, a metallurgical examination is recommended of as-received pipe for DWPF bubblers prior to beginning fabrication.

4. Perform modified ASTM C621 tests in glycolic acid feeds to determine impact of glycolic acid vs. formic acid with and without the impact of Ar bubbling, i.e. all the formic acid flowsheet 
corrosion data has been derived in non-bubbled pilot scale melters except for the CEF glycolic acid campaign. This should suffice to get more precise comparative corrosion data for the Monofrax TM K-3.

\subsection{Conclusions}

The use of glycolic acid as an alternate reductant for the DWPF flowsheet has shown an impact on the corrosion susceptibility of some materials of construction in the DWPF and downstream facilities, especially at elevated temperatures. The materials of construction for most vessels, components and piping were not impacted with the presence of glycolic acid or the impact is not expected to affect the service life. Material and waste stream combinations that showed increased corrosion or localized corrosion include:

- $\quad 304 \mathrm{~L}$ in $70 \%$ glycolic acid at $50{ }^{\circ} \mathrm{C}$

- $\quad$ C276, Ultimet and Stellite in boiling $\left(\sim 100^{\circ} \mathrm{C}\right)$ SRAT/SME supernate

- $\mathrm{G} 30$ in boiling basic concentrated recycle

- G3 in boiling dilute waste

- $\quad$ Monofrax ${ }^{\mathrm{TM}} \mathrm{K}-3$ in molten glass

Further testing was outlined to develop service condition limits for these materials in the particular chemical streams when glycolic acid is used as the reductant and the glycolate anion is present in the streams.

\subsection{Acknowledgements}

The authors would like to acknowledge the work of the following individuals that assisted in the successful completion of this project: Patrick O'Rourke and Henry Ajo (SEM/EDS), David Missimer (XRF), Gary Dobos and Curt Sexton (glassblower); Kevin Kalbaugh (bubbler evaluation), Carla Loftin (procurement), Sarita Berry and Leslie Wells (waste disposal).

\subsection{References}

1. D.P. Lambert, M.E. Stone, J.D. Newell, D.R. Best, and J.R. Zamecnik, "Glycolic-Nitric Acid Flowsheet Demonstration of the DWPF Chemical Process Cell with Sludge and Supernate Simulants, SRNL-STI-2012-00018, Revision 1, August 2012

2. Task Technical Request: Impact of Nitric-Glycolic Acid Flowsheet - Material Evaluation for DWPF and Downstream Tank Farm Processes, HLW-DWPF-TTR-2013-0004, Revision 0, October 31, 2012

3. J. I Mickalonis and T. E. Skidmore, "Material Compatibility Evaluation for DWPF Nitric-Glycolic Acid - Literature Review,” SRNL-STI-2013-00281, Revision 0, June 2013

4. F. C. Johnson, "Task Technical and Quality Assurance Plan for Alternative Reductant Melter Evaluation,” SRNL-RP-2012-00596, Revision 0, November 7, 2012

5. D. P. Lambert, "Task Technical and Quality Assurance Plan for Phase II CPC Testing for NitricGlycolic Flowsheet Development,” SRNL-RP-2012-00762, Revision 0, November 12, 2012

6. C. A. Nash, T. B. Peters, and F. F. Fondeur, "Task Technical and Quality Assurance Plan for Glycolate and new Guanidine Solvent Testing for MCU,” SRNL-PR-2014-00197, Revision 0, March 2014

7. A. R. Shafer, "Waste Acceptance Criteria for Sludge, ARP and MCU Process Transfers to 512-S and DWPF,” X-SD-G-00008, Revision 3, October 2008 
8. T. L. Fellinger and N. E. Bibler, "Results for the DWPF Slurry Mix Evaporator Condensate Tank, Off Gas Condensate Tank, and Recycle Collection Tank Samples,” WSRC-TR-2004-00577, Revision 0, December 21, 2004

9. J. M. Pareizs, J. R. Zamecnik, C. J. Coleman, and D. P. Lambert, ”Analysis of DWPF CPC Mercury Samples,” SRNL-3100-2014-00038, March 16, 2015

10. D. P. Lambert, B.R. Pickenheim, M.E. Stone, J.D. Newell, and D.R. Best, "Glycolic -Formic Acid Flowsheet Final Report for Downselection Decision,” SRNL-STI-2010-00523 Rev. 1, March 9, 2010

11. M. S. Hay and T. L. Fellinger, "Characterization and Dissolution Test Results for the January 2005 DWPF Off Gas Condesated Tank Samples,” WSRC-TR-2005-00141, Revision 0, April 8. 2005

12. M. E. Stone, "Bounding Glycolate Concentration in DWPF Recycle," SRNL-NB-2011-00021, Glycolic-Formic Flowsheet Development Part I, p. 175

13. C. J. Martino, "Simulated Waste Testing of Glycolate Impacts on the 2H-Evaporartor System," SRNL-STI-2013-00166, Revision 0, August 2013

14. C. A. Nash, T. B. Peters, and S. D. Fink,"Tank 49H Salt Batch Supernate Qualification for ARP/MCU,” WSRC-STI-2008-00117, Revision 0, August 25. 2008

15. Waste Chemistry System, Tank 50 material balance

16. K. Adu-Wusu, "Literature Review on Impact of Glycolate on the $2 \mathrm{H}$ Evaporator and the Effluent Treatment Facility (ETF),” SRNL-STI-2012-00132, Revision 0, May 2012

17. G5 - 13, "Standard Reference Test Method for Making Potentiodynamic Anodic Polarization Measurements,” ASTM International, West Conshohocken, PA 2014

18. G59 - 97 (Reapproved 2009), "Standard Test Method for Conducting Potentiodynamic Polarization Resistance Measurements,” ASTM International, West Conshohocken, PA 2014

19. G61 - 86 (Reapproved 2009), "Standard Test for Conducting Cyclic Potentiodynamic Polarization Measurements for Localized Corrosion Susceptibility of Iron-, Nickel-, or Cobalt-Based Alloys” ASTM International, West Conshohocken, PA 2014

20. G102 - 89 (Reapproved 2010), "Standard Practice for Calculation of Corrosion Rates and Related Information from Electrochemical Measurements," ASTM International, West Conshohocken, PA 2014

21. G. T. Chandler, P. E. Zapp, and J. I. Mickalonis, "Hot-Wall Corrosion Testing Of Simulated HighLevel Nuclear Waste,” CORROSION/95, Paper no. 431 (Houston, TX: NACE International), 1995

22. Revie and Uhlig, Corrosion Handbook

23. W. L. Daugherty, "Evaluation of Potential for Materials Degradation of DWPF Safety Class and Safety Significant Components,” WSRC-Tr-95-0385, Revision 0, September 1995

24. K. J. Imrich and D. C. Iverson, "Metallurgical Evaluation Of An Inconel 690 Insert From A Radioactive Waste Glass Melter Pour Spout (U), Ceramic Transactions, American Ceramics Society (ACerS), 1998

25. C.M. Jantzen, K.G. Brown, K.J. Imrich, and J.B. Pickett, "High Cr2O3 Refractory Corrosion in Oxidizing Melter Feeds: Relevance to Nuclear and Hazardous Waste Vitrification," Ceramic Transactions, v. 93, J.C. Marra and G.T. Chandler (Eds.), American Ceramic Society, Westerville, OH, 203-212 (1999).

26. C.M. Jantzen, K.J. Imrich, K.G.Brown, and J.B. Pickett, "High Chrome Refractory Characterization: Part I. Impact of Melt Pool REDuction/Oxidation (REDOX) on the Corrosion Mechanism in Radioactive Waste Glass Melters,” International Journal of Applied Glass Science (in press).

27. G.G. Wicks, "Melter Materials Compatibility Program, Part I: Static and Dynamic Finger TestsSimulated Glass Waste," U.S. DOE Report DPST-78-465, E.I. duPont deNemours \& Co., Savanannah River Laboratory, Aiken, SC, August, 1978 
28. G.G. Wicks, "Melter Materials Compatibility Program, Part II: Static and Dynamic Finger Tests, Radioactive Waste Glass and Long-Term Simulated Tests," U.S. DOE Report DPST-79-526, E.I. duPont deNemours \& Co., Savanannah River Laboratory, Aiken, SC November, 1979

29. G.G. Wicks, "Compatibility Tests of Materials for A Prototype Ceramic Melter for Defense Waste Products," Ceramics in Nuclear Waste Management, U.S. DOE Report CONF-790420, U.S. Dept. of Energy, Natil. Tech. Info. Serv., Springfield, VA 82-85, 1979

30. G.G. Wicks, "Corrosion of Melter Materials," U.S. DOE Report DPST-79-580, E.I. duPont deNemours \& Co., Savanannah River Laboratory, Aiken, SC, May, 1980

31. W.N. Rankin, "Evaluation of Glass-Contact Materials for Waste Glass Melters," Nuclear Waste Management, Advances in Ceramics, V. 8, G.G. Wicks and W.A. Ross (Eds.), Am. Ceram. Soc., Westerville, OH, 559-566, 1984

32. W.N. Rankin, “Corrosion of Melter Materials: Part III. Effect of Na2O,” U.S. DOE Report DPST81-933, E.I. duPont deNemours \& Co., Savanannah River Laboratory, Aiken, SC, February, 1982

33. C.M. Jantzen and D.P. Lambert, "Inspection and Analysis of the Integrated DWPF Melter System (IDMS) After Seven Years of Operation,” U.S. DOE Report WSRC-RP-575, Westinghouse Savannah River Co., Aiken, SC, February, 1997

34. W.A. Miller and W.C. Steggs, "Evolution and Application of Chrome Bearing Fused Cast Refractories,” Carborundum Co, Falconer, NY (1975) as cited in Reference 6

35. Muan and E.F. Osborn, "Phase Equilibria Among Oxides in Steelmaking," Addison-Wesley Publishing Company, Inc., Reading, MA, 236pp, 1965

36. D.C. Iverson and D.F. Bickford, "Evaluation of Materials Performance in a Large-Scale Glass Melter After Two Years of Vitrifying Simulated SRP Defense Waste,” Sci. Basis for Nucl. Waste Mgt., VIII, Mat. Res. Soc., Pittsburgh, PA, 839-845, 1985

37. Jantzen,C.M., Imrich, K.J., Brown, K.G., and Pickett, J.B., "High Chrome Refractory Characterization: Part II. Accumulation of Spinel Corrosion Deposits in Radioactive Waste Glass Melters," (accepted International Journal of Applied Glass Science)

38. S.A. Degterov and A.D. Pelton, "Thermodynamic Calculation of Glass/Slag/Refractory Equilibria in Coal Gassification,” Corrosion of Materials by Molten Glass, G.A. Pecoraro, et.al. (Eds), Ceram. Trans., V. 78, Am. Ceram. Soc., Westerville, OH, 91-103, 1996

39. H.D. Schreiber and A.L. Hockman, "Redox Chemistry in Candidate Glasses for Nuclear Waste Immobilization,” J. Am. Ceram. Soc., 70[8], 591-594

40. M.J. LaMont and P. Hrma, "A Crucible Study of Spinel Settling in a AHigh-Level Waste Glass," Ceramic Trans. V. 87, 343-348, 1998

41. J. Klouzek, J. Alton, P. Hrma, and T. Plaisted, "Crucible Study of Spinel Settling in Molten HighLevel Waste Glass,” Ceramic Trans. V. 119, 301-308, 2001

42. J.W. Amoroso, D.K. Peeler, and T.B. Edwards, "Elimination of the Characterization of DWPF Pour Stream Sample and the Glass Fabrication and Testing of the DWPF Sludge Batch Qualification Sample,” U.S. DOE Report SRNL-STI-2012-00157, Rev.0, Savannah River National Laboratory, Aiken, SC, 2012

43. S.A. Cooper and P.S. Nicholson, "Influence of Glass Redox Conditions on the Corrosion of FusionCast Chrome-Alumina Refractories,” Ceramic Bulletin, 59[7], 715-717, 1980

44. W.N. Rankin, "Corrosion of Melter Materials-II. Effect of Temperature,” U.S. DOE Report DPST81-602, E.I. DuPont deNemours \& Co., Savannah River Laboratory, Aiken, SC, 1981

45. Corning Engineering Laboratory Services Report for W.N. Rankin, \#11988-008, July 31, 1985 
46. N.E. Bibler, O.B. Hodoh, and T.F. Fellinger, "Analysis and Water Leaching of a Radioactive Sample from the Pour Spout of the DWPF Melter," U.S. DOE Report, WSRC-RP-96-618, DRAFT, Westinghouse Savannah River Company, Aiken, SC, December 12, 1996

47. C.M. Jantzen and D.P. Lambert, "Inspection and Analysis of the Integrated DWPF Melter System (IDMS) After Seven Years of Operation,” U.S. DOE Report WSRC-RP-575, Westinghouse Savannah River Co., Aiken, SC, February, 1997

48. "Basic Data Report Defense Waste Processing Facility Sludge Plant Savannah River Site 200-S Area,” U.S. DOE Report, WSRC-RP-92-1186 (DPSP 80-1033), Westinghouse Savannah River Company, Aiken, SC, Part 20, Items 230, Rev. 139, July, 1992

49. "Technical Data Summary for the Defense Waste Processing Facility Sludge Plant," U.S. DOE Report, DPSTD 80-38-2, DuPont DeNemours \& Co., Savannah River Laboratory, Aiken, SC 29808, Part 10, Item 405, Rev. 0, September 1982

50. F. C. Johnson, M. E. Stone, and D. H. Miller, "Alternate Reductant Cold Cap Evaluation Furnace Phase II Testing,” SRNL-STI-2014-00157, Revision 0, September 2014

51. J.B. Pickett, M-Area vitrification process contract monitor (personal communication)Glass Melter Pour Spout,” WSRC-MS-98-00870, Revision 0, September 1999

52. B. J. Wiersma, "Treatment Tank Corrosion Studies for the Enhanced Chemical Cleaning Process," SRNL-STI-2010-00535, Revision 1, August 2011

53. B. J. Wiersma and J. I. Mickalonis," Determination Of Corrosion Inhibitor Criteria For Type III/IIIA Tanks During Salt Dissolution Operations,” WSRC-STI-2006-00029, November 2006

54. A. Hansen, “CSTF Corrosion Control Program,” WSRC-TR-2002-00327, Revision 7, April 2013 
Attachment 1 Vessels and Components in the DWPF and Downstream Facilities that may Contact the Glycolate Anion or Glycolic Acid

\begin{tabular}{|c|c|c|c|c|c|}
\hline System/Component & Materials & $\begin{array}{c}\text { Temperature } \\
\left({ }^{\circ} \mathrm{C}\right)\end{array}$ & $\begin{array}{c}\text { Estimated } \\
\text { Glycolate } \\
\text { Concentration } \\
\end{array}$ & pH & $\begin{array}{c}\text { Test } \\
\text { Category }^{1}\end{array}$ \\
\hline \multicolumn{6}{|l|}{ DWPF System } \\
\hline $\begin{array}{l}\text { Acid unloading piping } \\
\text { and pump }\end{array}$ & 316/316L & 40 & $70 \%$ & 0.1 & 1 \\
\hline $\begin{array}{l}\text { Glycolic acid storage } \\
\text { tank, piping, pump, relief } \\
\text { valve }\end{array}$ & $316 L$ & 40 & $70 \%$ & 0.1 & 1 \\
\hline $\begin{array}{l}\text { Acid feed tank, piping, } \\
\text { drain header, spool piece, } \\
\text { and pen }\end{array}$ & 316/316L/304L & 40 & $70 \%$ & 0.1 & 1 \\
\hline $\begin{array}{l}\text { Acid drain catch tank, } \\
\text { agitator, pumps, drain } \\
\text { header }\end{array}$ & 316/316L/304L & 40 & $70 \%$ & 0.1 & 1 \\
\hline SEFT & SS & 40 & minimal & 2 to 12 & No testing \\
\hline LPPP-PPT & $304 \mathrm{~L}$ & & minimal & 12 to 13.5 & No testing \\
\hline PRFT & $\mathrm{C} 276$ & 40 & minimal & 12 to 13.5 & No testing \\
\hline $\begin{array}{l}\text { RCT - vessel, cooling } \\
\text { coils, agitator, pumps }\end{array}$ & $\mathrm{C} 276$ & 50 & $10 \mathrm{~g} / \mathrm{L}$ & 1 to 14 & 4 \\
\hline $\begin{array}{l}\text { SRAT - vessel, agitator, } \\
\text { coil guides, pumps, } \\
\text { condenser, jumpers, } \\
\text { piping }\end{array}$ & C276/Stellite & 103 & $0.65 \mathrm{M}$ & 3.5 to 5 & $\begin{array}{c}\text { 2, 22-L CPC } \\
\text { coupon test }\end{array}$ \\
\hline SRAT - coils & $\mathrm{C} 276$ & 160 & $0.65 \mathrm{M}$ & 3.5 to 5 & 2, HW1 \\
\hline MWWT & $304 \mathrm{~L}$ & 50 & 4 & 5 to 6 & 3 \\
\hline $\begin{array}{l}\text { SME - vessel, agitator, } \\
\text { condenser, pumps, } \\
\text { jumper, piping, coil } \\
\text { guides }\end{array}$ & C276/Stellite & 103 & $0.65 \mathrm{M}$ & 5 to 6 & $\begin{array}{c}\text { 2, 22-L CPC } \\
\text { coupon test }\end{array}$ \\
\hline SME - coils & C276/Ultimet $^{3}$ & 160 & $0.65 \mathrm{M}$ & 5 to 6 & 2, HW1 \\
\hline $\begin{array}{l}\text { SME condensate tank, } \\
\text { cooling coils, sparger, } \\
\text { jumpers, piping, pumps }{ }^{2}\end{array}$ & 316L/C276 & 50 & 4 & 5 to 6 & 3 \\
\hline $\begin{array}{l}\text { MFT - vessel, cooling } \\
\text { coils, agitator, pumps, } \\
\text { jumpers, feed tube }\end{array}$ & C276/Stellite/316L & 100 & $0.65 \mathrm{M}$ & 5 to 6 & 2 \\
\hline $\begin{array}{l}\text { Melter - electrodes, dome } \\
\text { heaters, film cooler, } \\
\text { bubbler, refractory }\end{array}$ & 690/K3 & 1150 & ND & & CEF coupon test \\
\hline \multicolumn{6}{|l|}{ Off-gas system } \\
\hline Quencher & Allcorr $/ 276^{3}$ & 90 to 600 & $10 \mathrm{~g} / \mathrm{L}$ & 0 to 8 & 4 \\
\hline Condenser & $\mathrm{C} 276$ & 10 & $10 \mathrm{~g} / \mathrm{L}$ & 0 to 8 & 4 \\
\hline $\begin{array}{l}\text { Condensate tank, } \\
\text { cooling coils, pumps, } \\
\text { jumpers }\end{array}$ & $\mathrm{C} 276$ & 50 & $10 \mathrm{~g} / \mathrm{L}$ & 0 to 8 & 4 \\
\hline \multicolumn{6}{|l|}{ Tank Farm } \\
\hline Transfer lines - inner & $304 \mathrm{~L}$ & 30 & $10 \mathrm{~g} / \mathrm{L}$ & 13 & $4-6$ \\
\hline Transfer lines - outer & A53/A106 & 30 & $10 \mathrm{~g} / \mathrm{L}$ & 13 & $4-6$ \\
\hline Pump tanks & 304L & 30 & $10 \mathrm{~g} / \mathrm{L}$ & 13 & $4-6$ \\
\hline $\begin{array}{l}\text { Waste tank (Tanks 13, 22, } \\
38,41,43,49 \text { and 50) }\end{array}$ & A537/A285 & 39 to 100 & $10 \mathrm{~g} / \mathrm{L}$ & 13 & $4-6$ \\
\hline
\end{tabular}


SRNL-STI-2014-00281

Revision 0

\begin{tabular}{|c|c|c|c|c|c|}
\hline System/Component & Materials & $\begin{array}{c}\text { Temperature } \\
\left({ }^{\circ} \mathrm{C}\right)\end{array}$ & $\begin{array}{c}\text { Estimated } \\
\text { Glycolate } \\
\text { Concentration }\end{array}$ & pH & $\begin{array}{c}\text { Test } \\
\text { Category }^{1}\end{array}$ \\
\hline \multicolumn{6}{|l|}{ 2H Evaporator System } \\
\hline Pot & $304 \mathrm{~L}$ & 100 & $10 \mathrm{~g} / \mathrm{L}$ & 13 & 5 \\
\hline Tube bundle & G30 & 160 & $10 \mathrm{~g} / \mathrm{L}$ & 13 & 5, HW2 \\
\hline Condenser & 304L & 10 & $0.033 \mathrm{~g} / \mathrm{L}$ & 3 to 12 & 8 \\
\hline Overheads tank & $304 \mathrm{~L}$ & 93 & $0.033 \mathrm{~g} / \mathrm{L}$ & 3 to 12 & 8 \\
\hline Condensate tank & $304 \mathrm{~L}$ & 93 & $0.033 \mathrm{~g} / \mathrm{L}$ & 3 to 12 & 8 \\
\hline Pumps/valves/piping & $304 \mathrm{~L} / 316 \mathrm{~L}$ & 30 & $10 \mathrm{~g} / \mathrm{L}$ & 13 & 8 \\
\hline \multicolumn{6}{|l|}{ ETF Evaporator System } \\
\hline pH Adjustment tank & & 30 & $0.033 \mathrm{~g} / \mathrm{L}$ & 6 to 8 & 8 \\
\hline Filtration & & 30 & $0.033 \mathrm{~g} / \mathrm{L}$ & 6 to 8 & 8 \\
\hline Organic removal & $\mathrm{CS} / 304 \mathrm{~L}$ & 66 & $0.033 \mathrm{~g} / \mathrm{L}$ & 6 to 8 & 8 \\
\hline Reverse osmosis & CS/304L & 35 & $0.033 \mathrm{~g} / \mathrm{L}$ & 6 & 8 \\
\hline Ion exchange & $304 \mathrm{~L}$ & & $0.033 \mathrm{~g} / \mathrm{L}$ & 6 & 8 \\
\hline Feed tanks and pumps & $304 \mathrm{~L}$ & 16 & $0.033 \mathrm{~g} / \mathrm{L}$ & 6 & 8 \\
\hline Vapor body & SS & & $0.033 \mathrm{~g} / \mathrm{L}$ & 4 to 5 & 8 \\
\hline Evaporator heater & G3/Alloy20 & 107 & $0.033 \mathrm{~g} / \mathrm{L}$ & 4 to 5 & 8, HW3 \\
\hline Condenser tubes & $316 \mathrm{~L}$ & 149 & No data & No data & 8 \\
\hline $\begin{array}{l}\text { Condensate } \\
\text { tanks/pumps }\end{array}$ & & 27 to 49 & $0.025 \mathrm{~g} / \mathrm{L}$ & & 8 \\
\hline $\begin{array}{l}\text { Concentrate } \\
\text { tanks/pumps }\end{array}$ & & 107 & $0.033 \mathrm{~g} / \mathrm{L}$ & & 8 \\
\hline \multicolumn{6}{|l|}{ ARP } \\
\hline Strike tanks & $304 \mathrm{~L}$ & 40 & $10 \mathrm{~g} / \mathrm{L}$ & 12 to 13.5 & 6 \\
\hline $\begin{array}{l}\text { Precipitate } \\
\text { (LWPT) }\end{array}$ & $304 \mathrm{~L}$ & 28 & $10 \mathrm{~g} / \mathrm{L}$ & 2 to 13.5 & 6 \\
\hline Cross-flow filter & SS & & $10 \mathrm{~g} / \mathrm{L}$ & 12 to 13.5 & 6 \\
\hline Filtrate hold tank & $304 \mathrm{~L}$ & $<50$ & $10 \mathrm{~g} / \mathrm{L}$ & 12 to 13.5 & 6 \\
\hline \multicolumn{6}{|l|}{ MCU } \\
\hline Receipt and feed tanks & $304 \mathrm{~L}$ & 30 & $10 \mathrm{~g} / \mathrm{L}$ & 13 & 6 \\
\hline Extraction contactors & $316 \mathrm{~L}$ & 26 & $10 \mathrm{~g} / \mathrm{L}$ & 13 & 6 \\
\hline Strip contactors & $316 \mathrm{~L}$ & 39 & $10 \mathrm{~g} / \mathrm{L}$ & $5-8$ & 7 \\
\hline Scrub contactors & $316 \mathrm{~L}$ & 40 & $10 \mathrm{~g} / \mathrm{L}$ & 13 & 6 \\
\hline Wash contactors & $316 \mathrm{~L}$ & 40 & $10 \mathrm{~g} / \mathrm{L}$ & 13 & 6 \\
\hline $\begin{array}{l}\text { DSS decanter and hold } \\
\text { tanks }\end{array}$ & $304 \mathrm{~L}$ & 30 & $10 \mathrm{~g} / \mathrm{L}$ & 13 & 6 \\
\hline $\begin{array}{l}\text { Strip effluent decanter } \\
\text { and hold tanks }\end{array}$ & $304 \mathrm{~L}$ & 30 & minimal & 13 & 6 \\
\hline \multicolumn{6}{|l|}{ Saltstone } \\
\hline Salt feed tank & $\mathrm{CS}$ & 10 to 40 & $10 \mathrm{~g} / \mathrm{L}$ & 13 & 6 \\
\hline Feed line & SS & 40 & $10 \mathrm{~g} / \mathrm{L}$ & 13 & 6 \\
\hline Mixer & 316L/Astralloy & 40 & $10 \mathrm{~g} / \mathrm{L}$ & 13 & 6 \\
\hline Vault & Concrete & 95 & $10 \mathrm{~g} / \mathrm{L}$ & 13 & 6 \\
\hline
\end{tabular}


${ }^{1}$ See Attachment 2 for test conditions.

${ }^{2}$ Erosion/corrosion synergy is not being studied. For SME condensate tank the erosion could result from frit carryover from SME.

${ }^{3}$ Galvanic corrosion might be an issue in this region, not currently covered in task plan.

${ }^{4}$ Estimates of the concentration of glycolate for the MWWT and SMECT vary between 20 and 6000 $\mathrm{mg} / \mathrm{L}$ for normal and boil over conditions, respectively. During CPC testing a value of $180 \mathrm{mg} / \mathrm{L}$ was measured [1]. 


\section{Attachment 2 Experimental Test Matrices for Electrochemical and Hot-Wall Testing}

Table A2-1 Electrochemical Experimental Matrix

\begin{tabular}{|c|c|c|c|c|c|c|c|}
\hline \multirow{2}{*}{$\begin{array}{c}\text { Test } \\
\text { Category }\end{array}$} & \multirow{2}{*}{$\begin{array}{l}\text { Solution/Stream } \\
\text { Category }\end{array}$} & \multirow{2}{*}{ Systems/Vessels } & \multirow{2}{*}{$\begin{array}{l}\text { Materials of } \\
\text { Construction }\end{array}$} & \multicolumn{4}{|c|}{ Test Conditions } \\
\hline & & & & [GA] & Temperature & pH & Materials $^{\mu}$ \\
\hline 1 & GA feed and storage & DWPF acid Tanks/piping & 304L/316L & $70 \%$ & $40 \mathrm{C}$ & 0.1 & 304L, 316L \\
\hline \multirow[t]{2}{*}{2} & $\begin{array}{l}\text { SRAT supernate } \\
\text { chemistry }\end{array}$ & $\begin{array}{l}\text { SRAT/SME vessel, agitator, coil } \\
\text { guides }\end{array}$ & C276/Ultimet/Stellite & $0.65 \mathrm{M}$ & $103 \mathrm{C}$ & 3 & $\begin{array}{l}\text { C276, Ultimet, } \\
\text { Stellite }\end{array}$ \\
\hline & & Jumpers, valves samplers, piping & 304L & $0.65 \mathrm{M}$ & $50 \mathrm{C}$ & 3 & 304L, C276 \\
\hline \multirow[t]{2}{*}{3} & Dilute waste & SMECT and MWWT & 316L/304L & $0.18 \mathrm{~g} / \mathrm{L}$ & $50 \mathrm{C}$ & 6 & $316 \mathrm{~L}$ \\
\hline & & & & $6 \mathrm{~g} / \mathrm{L}$ & $50 \mathrm{C}$ & 6 & $304 \mathrm{~L}$ \\
\hline \multirow[t]{5}{*}{4} & Acidic recycle ${ }^{\gamma}$ & DWPF off-gas system & Allcorr/C276 & $10 \mathrm{~g} / \mathrm{L}$ & $50 \mathrm{C}$ & 1.5 & $\begin{array}{l}\text { C276, 304L, } \\
\text { 316L }\end{array}$ \\
\hline & & $\mathrm{RCT}$ & C276 & $10 \mathrm{~g} / \mathrm{L}$ & $50 \mathrm{C}$ & 8 & $\begin{array}{l}\text { C276, 304L, } \\
\text { 316L }\end{array}$ \\
\hline & & DWPF piping & 304L/316L & $10 \mathrm{~g} / \mathrm{L}$ & $100 \mathrm{C}$ & 1.5 & C276 \\
\hline & & Tank/transfer lines & A285/304L & $10 \mathrm{~g} / \mathrm{L}$ & $100 \mathrm{C}$ & 8 & $\mathrm{C} 276$ \\
\hline & & & & $10 \mathrm{~g} / \mathrm{L}$ & $50 \mathrm{C}$ & 13 & C276, A285 \\
\hline \multirow[t]{3}{*}{5} & $\begin{array}{l}\text { Basic concentrated } \\
\text { recycle }^{\delta}\end{array}$ & $2 \mathrm{H}$ evaporator components & 304L/316L & $10 \mathrm{~g} / \mathrm{L}$ & $30 \mathrm{C}$ & 13 & $\begin{array}{l}\text { A537, 304L, } \\
\text { 316L, G30 }\end{array}$ \\
\hline & & Evaporator coils & G30 & $10 \mathrm{~g} / \mathrm{L}$ & boiling & 13 & G30 \\
\hline & & Tanks/transfer lines & A537/304L & $10 \mathrm{~g} / \mathrm{L}$ & $100 \mathrm{C}$ & 13 & $304 \mathrm{~L}$ \\
\hline \multirow[t]{5}{*}{6} & $\begin{array}{l}\text { Basic salt } \\
\text { processing }^{\varepsilon}\end{array}$ & Saltstone & Astralloy/316L/CS/304L & $10 \mathrm{~g} / \mathrm{L}$ & $30 \mathrm{C}$ & 13 & $\begin{array}{l}\text { Astralloy, 304L, } \\
\text { 316L, CS }\end{array}$ \\
\hline & & ARP tanks & 304L & $10 \mathrm{~g} / \mathrm{L}$ & $50 \mathrm{C}$ & 13 & $\begin{array}{l}\text { Astralloy, 304L, } \\
\text { 316L, CS }\end{array}$ \\
\hline & & Waste tanks/transfer lines & A537/304L & & & & \\
\hline & & MCU vessels & 316L & & & & \\
\hline & & & & & & & \\
\hline
\end{tabular}




\begin{tabular}{|c|c|c|c|c|c|c|c|}
\hline \multirow{2}{*}{$\begin{array}{c}\text { Test } \\
\text { Category }\end{array}$} & \multirow{2}{*}{$\begin{array}{c}\text { Solution/Stream } \\
\text { Category }\end{array}$} & \multirow{2}{*}{ Systems/Vessels } & \multirow{2}{*}{$\begin{array}{l}\text { Materials of } \\
\text { Construction }\end{array}$} & \multicolumn{4}{|c|}{ Test Conditions } \\
\hline & & & & [GA] & Temperature & $\mathbf{p H}$ & Materials $^{\mu}$ \\
\hline 7 & Boric acid & MCU strip contactor & $316 \mathrm{~L}$ & $10 \mathrm{~g} / \mathrm{L}$ & $50 \mathrm{C}$ & 6 & 316L \\
\hline 8 & Dilute waste & 2H condensate tank and piping & $304 \mathrm{~L} / 316 \mathrm{~L} / \mathrm{CS}$ & $0.033 \mathrm{~g} / \mathrm{L}$ & $30 \mathrm{C}$ & 3 & 304L, 316L, CS \\
\hline & & ETF evaporator system & 304L/316L/CS/G3 & $0.033 \mathrm{~g} / \mathrm{L}$ & $30 \mathrm{C}$ & 6 & 304L, 316L, CS \\
\hline & & & & $0.033 \mathrm{~g} / \mathrm{L}$ & $30 \mathrm{C}$ & 12 & 304L, 316L, CS \\
\hline & & & & $0.033 \mathrm{~g} / \mathrm{L}$ & $95 \mathrm{C}$ & 3 & 304L, 316L, CS \\
\hline & & & & $0.033 \mathrm{~g} / \mathrm{L}$ & $95 \mathrm{C}$ & 12 & 304L, 316L, CS \\
\hline & & & & $0.033 \mathrm{~g} / \mathrm{L}$ & $107 \mathrm{C}$ & 5 & G3 \\
\hline
\end{tabular}

$\mu$ - CS indicates carbon steel; a particular grade was not identified; A537 will be used when CS is indicated

Table A2-2 Hot-Wall Experimental Matrix

\begin{tabular}{|c|c|c|c|c|c|c|c|}
\hline \multirow{2}{*}{$\begin{array}{c}\text { Test } \\
\text { Category }\end{array}$} & \multirow{2}{*}{ Solution/ Stream Category } & \multirow{2}{*}{ Systems/Vessel } & \multirow{2}{*}{$\begin{array}{c}\text { Material of } \\
\text { Construction }\end{array}$} & \multicolumn{4}{|c|}{ Test Conditions } \\
\hline & & & & [GA] & Temperature & pH & Materials \\
\hline HW1 & SRAT supernate chemistry & $\begin{array}{l}\text { SRAT/SME coils and coil } \\
\text { guides }\end{array}$ & C276/Ultimet & $0.65 \mathrm{M}$ & Boiling & 3 & C276, Ultimet \\
\hline HW2 & Basic concentrated recycle & 2H evaporator coils & G30 & $10 \mathrm{~g} / \mathrm{L}$ & Boiling & 13 & G30 \\
\hline HW3 & Dilute waste & ETF evaporator & G3 & $0.033 \mathrm{~g} / \mathrm{L}$ & Boiling & 5 & G3 \\
\hline
\end{tabular}


Attachment 3 Solution Makeup Chemistries for Electrochemical and Hot Wall Testing ${ }^{a}$

Table A3-1 SRAT/SME Supernate with Low Iron and Aggressive Species Concentrations

\begin{tabular}{|c|c|}
\hline Recipe & $\begin{array}{c}\text { 1L Solution } \\
\text { Mass, }\end{array}$ \\
\hline Aluminum Nitrate (Al(NO3)3.9H2O) & 3.5637 \\
\hline Calcium Nitrate (Ca(NO3)2.4H2O) & 0.6423 \\
\hline Iron Nitrate (Fe(NO3)3.9H2O) & 0.4040 \\
\hline Potassium Nitrate (KNO3) & 0.8288 \\
\hline Magnesium Nitrate (Mg(NO3)2.6H2O) & 2.1416 \\
\hline Nickel Nitrate (Ni(NO3)2.6H2O) & 17.3892 \\
\hline Ruthenium Chloride (RuCl3) - 41.74 Wt\% Ru & 0.4955 \\
\hline Rhodium Nitrate (4.933 Wt\% Solution) - liquid & 0.0217 \\
\hline Zirconium Nitrate (ZrO(NO3)2.6H2O) & 0.5285 \\
\hline Sodium Nitrate (NaNO3) & 0.0840 \\
\hline Sodium Glycolate (NaC2H3O3) & 63.6692 \\
\hline Sodium Oxalate (Na2C2O4) & 63.4888 \\
\hline Sodium Sulfate (Na2SO4) & 5.7851 \\
\hline Sodium Chloride (NaCl) & 2.8408 \\
\hline Mercury Nitrate (Hg(NO3)2.H2O & 0.0584 \\
\hline
\end{tabular}

Solutions made without the glycolate anion used the same compositions except sodium glycolate was not added.

\footnotetext{
${ }^{\mathrm{a}}$ The chemistries listed in this section were those used for making solutions. Actual values were mostly $\pm 0.0003 \mathrm{~g}$.
} 
Table A3-2 SRAT/SME Supernate with Low Iron and High Aggressive Species Concentrations

\begin{tabular}{|c|c|}
\hline Recipe & $\begin{array}{c}\text { 1L Solution } \\
\text { Mass, }\end{array}$ \\
\hline Aluminum Nitrate (Al(NO3)3.9H2O) & 3.5637 \\
\hline Calcium Nitrate (Ca(NO3)2.4H2O) & 0.6423 \\
\hline Iron Nitrate (Fe(NO3)3.9H2O) & 0.4040 \\
\hline Potassium Nitrate (KNO3) & 0.8288 \\
\hline Magnesium Nitrate (Mg(NO3)2.6H2O) & 2.1416 \\
\hline Nickel Nitrate (Ni(NO3)2.6H2O) & 17.3892 \\
\hline Ruthenium Chloride (RuCl3) - 41.74 Wt\% Ru & 0.4955 \\
\hline Rhodium Nitrate (4.933 Wt\% Solution) - liquid & 0.0217 \\
\hline Zirconium Nitrate (ZrO(NO3)2.6H2O) & 0.5285 \\
\hline Sodium Nitrate (NaNO3) & 0.0840 \\
\hline Sodium Glycolate (NaC2H3O3) & 63.6692 \\
\hline Sodium Oxalate (Na2C2O4) & 63.4888 \\
\hline Sodium Sulfate (Na2SO4) & 5.7851 \\
\hline Sodium Chloride (NaCl) & 8.2383 \\
\hline Mercury Nitrate (Hg(NO3)2.H2O & 9.2335 \\
\hline Non 20.8692 \\
\hline
\end{tabular}

Solutions made without the glycolate anion used the same compositions except sodium glycolate was not added. 
Table A3-3 SRAT/SME Supernate with High Iron and High Aggressive Species Concentrations

\begin{tabular}{|c|c|}
\hline Recipe & $\begin{array}{c}\text { 1L Solution } \\
\text { Mass, }\end{array}$ \\
\hline Aluminum Nitrate (Al(NO3)3.9H2O) & 0.5627 \\
\hline Calcium Nitrate (Ca(NO3)2.4H2O) & 0.6423 \\
\hline Iron Nitrate (Fe(NO3)3.9H2O) & 3.636 \\
\hline Potassium Nitrate (KNO3) & 0.8288 \\
\hline Magnesium Nitrate (Mg(NO3)2.6H2O) & 2.1416 \\
\hline Nickel Nitrate (Ni(NO3)2.6H2O) & 17.3892 \\
\hline Ruthenium Chloride (RuCl3) - 41.74 Wt\% Ru & 0.4955 \\
\hline Rhodium Nitrate (4.933 Wt\% Solution) - liquid & 0.0217 \\
\hline Zirconium Nitrate (ZrO(NO3)2.6H2O) & 0.5285 \\
\hline Sodium Nitrate (NaNO3) & 0.0840 \\
\hline Sodium Glycolate (NaC2H3O3) & 63.6692 \\
\hline Sodium Oxalate (Na2C2O4) & 63.4888 \\
\hline Sodium Sulfate (Na2SO4) & 5.7851 \\
\hline Sodium Chloride (NaCl) & 8.2383 \\
\hline Mercury Nitrate (Hg(NO3)2.H2O & 9.2335 \\
\hline Non 20.8692 \\
\hline
\end{tabular}

Solutions made without the glycolate anion used the same compositions except sodium glycolate was not added. 
Table A3-4 SME Condensate Simulant with 0.18 g/L Sodium Glycolate

\begin{tabular}{|c|c|}
\hline Recipe & $\begin{array}{c}\text { 1.2 Solution } \\
\text { Mass, } \mathbf{g}\end{array}$ \\
\hline Aluminum Nitrate $(\mathrm{Al}(\mathrm{NO} 3) 3 \cdot 9 \mathrm{H} 2 \mathrm{O}$ & 0.1502 \\
\hline Mercury Nitrate $(\mathrm{Hg}(\mathrm{NO} 3) 2 \cdot \mathrm{H} 2 \mathrm{O}$ & 0.41 \\
\hline Iron Nitrate $(\mathrm{Fe}(\mathrm{NO} 3) 3.9 \mathrm{H} 2 \mathrm{O})$ & 2.6041 \\
\hline Sodium Formate $(\mathrm{NaCHO} 2)$ & 0.7798 \\
\hline Sodium Glycolate $(\mathrm{NaC2H} 3 \mathrm{O} 3)$ & 0.216 \\
\hline Sodium Sulfate $(\mathrm{Na2SO} 4)$ & 0.0391 \\
\hline
\end{tabular}

Solutions made without the glycolate anion used the same compositions except sodium glycolate was not added.

Table A3-5 SME Condensate Simulant with 6 g/L Sodium Glycolate

\begin{tabular}{|c|c|}
\hline Recipe & $\begin{array}{c}\text { 1.2 Solution } \\
\text { Mass, } \mathbf{g}\end{array}$ \\
\hline Aluminum Nitrate $(\mathrm{Al}(\mathrm{NO} 3) 3 \cdot 9 \mathrm{H} 2 \mathrm{O}$ & 0.1502 \\
\hline Mercury Nitrate $(\mathrm{Hg}(\mathrm{NO} 3) 2 \cdot \mathrm{H} 2 \mathrm{O}$ & 0.41 \\
\hline Iron Nitrate $(\mathrm{Fe}(\mathrm{NO} 3) 3.9 \mathrm{H} 2 \mathrm{O})$ & 2.6041 \\
\hline Sodium Formate $(\mathrm{NaCHO} 2)$ & 0.7798 \\
\hline Sodium Glycolate $(\mathrm{NaC} 2 \mathrm{H} 3 \mathrm{O} 3)$ & 7.2 \\
\hline Sodium Sulfate $(\mathrm{Na} 2 \mathrm{SO} 4)$ & 0.0391 \\
\hline
\end{tabular}

Solutions made without the glycolate anion used the same compositions except sodium glycolate was not added. 
Table A3-6 Acid Recycle at $\mathrm{pH}$ 1.5*

\begin{tabular}{|c|c|}
\hline Recipe & $\begin{array}{l}\text { 1.2L Solution Mass, } \\
\mathrm{g}\end{array}$ \\
\hline Aluminum Nitrate $(\mathrm{Al}(\mathrm{NO} 3) 3.9 \mathrm{H} 2 \mathrm{O})$ & 0.3919 \\
\hline Iron Nitrate $(\mathrm{Fe}(\mathrm{NO} 3) 3.9 \mathrm{H} 2 \mathrm{O})$ & 0.1962 \\
\hline $\begin{array}{c}\text { Manganese Nitrate (50 wt } \% \mathrm{Mn}(\mathrm{NO}) 2+5 \mathrm{Wt} \% \\
\text { HNO3) - liquid }\end{array}$ & 0.0527 \\
\hline Sodium Glycolate (NaC2H3O3) & 15.672 \\
\hline Sodium Fluoride (NaF) & 0.0504 \\
\hline Sodium Chloride ( $\mathrm{NaCl})$ & 0.0099 \\
\hline
\end{tabular}

* Adjusted with additional nitric acid to reach desired $\mathrm{pH}$

Solutions made without the glycolate anion used the same compositions except sodium glycolate was not added.

Table A3-7 Acid Recycle at pH 8

\begin{tabular}{|c|c|}
\hline Recipe & $\begin{array}{l}\text { 1.2L Solution Mass, } \\
\mathrm{g}\end{array}$ \\
\hline Aluminum Nitrate $(\mathrm{Al}(\mathrm{NO} 3) 3.9 \mathrm{H} 2 \mathrm{O})$ & 0.3919 \\
\hline Iron Nitrate $(\mathrm{Fe}(\mathrm{NO} 3) 3.9 \mathrm{H} 2 \mathrm{O})$ & 0.1962 \\
\hline $\begin{array}{c}\text { Manganese Nitrate (50 wt } \% \text { Mn(NO3)2 + } 5 \mathrm{Wt} \% \\
\text { HNO3) - liquid }\end{array}$ & 0.0527 \\
\hline Sodium Glycolate (NaC2H3O3) & 15.672 \\
\hline Sodium Fluoride (NaF) & 0.0504 \\
\hline Sodium Chloride ( $\mathrm{NaCl})$ & 0.0099 \\
\hline Sodium Nitrate (NaNO3) & 2.62 \\
\hline Sodium Sulphate (Na2SO4) & 0.108 \\
\hline
\end{tabular}

Solutions made without the glycolate anion used the same compositions except sodium glycolate was not added. 
Table A3-8 Acid Recycle at pH 13

\begin{tabular}{|c|c|}
\hline Recipe & $\mathbf{1 . 2 L}$ Solution Mass, \\
\hline Sodium Hydroxide $(\mathrm{NaOH})$ & 4.0 \\
\hline Aluminum Nitrate $(\mathrm{Al}(\mathrm{NO} 3) 3.9 \mathrm{H} 2 \mathrm{O})$ & 0.01 \\
\hline Iron Nitrate $(\mathrm{Fe}(\mathrm{NO} 3) 3.9 \mathrm{H} 2 \mathrm{O})$ & 0.0161 \\
\hline Sodium Glycolate $(\mathrm{NaC} 2 \mathrm{H} 3 \mathrm{O} 3)$ & 15.672 \\
\hline Sodium Formate $(\mathrm{NaC} 2 \mathrm{HO} 2)$ & 0.562 \\
\hline Sodium Nitrate $(\mathrm{NaNO} 3)$ & 7.8 \\
\hline Sodium Nitrite $(\mathrm{NaNO} 2)$ & 7.34 \\
\hline Sodium Sulphate $(\mathrm{Na2SO} 4)$ & 0.0852 \\
\hline
\end{tabular}

Solutions made without the glycolate anion used the same compositions except sodium glycolate was not added.

Table A3-9 Basic Concentrated Recycle

\begin{tabular}{|c|c|}
\hline Recipe & 1-L Desired Mass, $\mathbf{~}$ \\
\hline Sodium Hydroxide $(\mathrm{NaOH})$ & 0.4 \\
\hline Sodium Carbonate $(\mathrm{Na2CO} 3)$ & 48.02 \\
\hline Sodium Sulfate $(\mathrm{Na} 2 \mathrm{SO} 4)$ & 2.66 \\
\hline Sodium Phosphate $(\mathrm{Na3PO} 4 \cdot 12 \mathrm{H} 2 \mathrm{O})$ & 1.6 \\
\hline Sodium Formate $(\mathrm{NaCHO})$ & 2.4 \\
\hline Sodium Glycolate $(\mathrm{NaC} 2 \mathrm{H} 3 \mathrm{O} 3)$ & 13.06 \\
\hline Sodium Oxalate $(\mathrm{Na2C} 2 \mathrm{O} 4)$ & 0.26 \\
\hline Sodium Nitrate $(\mathrm{NaNO} 3)$ & 90.1 \\
\hline Sodium Nitrite $(\mathrm{NaNO} 2)$ & 113.62 \\
\hline
\end{tabular}

Solutions made without the glycolate anion used the same compositions except sodium glycolate was not added. 
Table A3-10 Salt Processing

\begin{tabular}{|c|c|}
\hline Recipe & Mass for 1L, $\mathbf{~}$ \\
\hline Sodium Hydroxide $(\mathrm{NaOH})$ & 0.4 \\
\hline Sodium Carbonate $(\mathrm{Na2CO})$ & 27.5574 \\
\hline Sodium Sulfate $(\mathrm{Na2SO} 4)$ & 13.4346 \\
\hline Sodium Chloride $(\mathrm{NaCl})$ & 0.4962 \\
\hline Sodium Phosphate $(\mathrm{Na3PO} 4 \cdot 12 \mathrm{H} 2 \mathrm{O})$ & 1.9727 \\
\hline Sodium Formate $(\mathrm{NaCHO} 2)$ & 0.6166 \\
\hline Sodium Glycolate $(\mathrm{NaC} 2 \mathrm{H} 3 \mathrm{O} 3)$ & 13.0707 \\
\hline Sodium Oxalate $(\mathrm{Na2C} 2 \mathrm{O} 4)$ & 0.5299 \\
\hline Sodium Nitrate $(\mathrm{NaNO})$ & 207.6772 \\
\hline Sodium Nitrite $(\mathrm{NaNO} 2)$ & 42 \\
\hline
\end{tabular}

Solutions made without the glycolate anion used the same compositions except sodium glycolate was not added.

Table A3-11 Dilute Waste at $\mathrm{pH}$ 3*

\begin{tabular}{|c|c|}
\hline Recipe & $\begin{array}{c}\mathbf{1 . 2 L} \text { Solution Mass, } \\
\mathbf{g}\end{array}$ \\
\hline Iron Nitrate $(\mathrm{Fe}(\mathrm{NO} 3) 3.9 \mathrm{H} 2 \mathrm{O})$ & 0.0029 \\
\hline Mercury Nitrate $(\mathrm{Hg}(\mathrm{NO} 3) 2 . \mathrm{H} 2 \mathrm{O}$ & 0.0077 \\
\hline Sodium Glycolate $(\mathrm{NaC} 2 \mathrm{H} 3 \mathrm{O} 3)$ & 0.0396 \\
\hline Sodium Sulfate $(\mathrm{Na2SO} 4)$ & 0.0604 \\
\hline Sodium Chloride $(\mathrm{NaCl})$ & 0.0356 \\
\hline
\end{tabular}

* Adjusted with additional nitric acid to reach desired $\mathrm{pH}$

Solutions made without the glycolate anion used the same compositions except sodium glycolate was not added. 
Table A3-12 Dilute Waste at pH 6

\begin{tabular}{|c|c|}
\hline Recipe & 1L Solution Mass, $\mathrm{g}$ \\
\hline Sodium Carbonate (Na2CO3) & 0 \\
\hline Calcium Nitrate $(\mathrm{Ca}(\mathrm{NO} 3) 2.4 \mathrm{H} 2 \mathrm{O})$ & 0.0061 \\
\hline Iron Nitrate (Fe(NO3)3.9H2O) & 0.0024 \\
\hline Potassium Nitrate (KNO3) & 0.0015 \\
\hline Magnesium Nitrate $(\mathrm{Mg}(\mathrm{NO} 3) 2.6 \mathrm{H} 2 \mathrm{O})$ & 0.001 \\
\hline Ammonium Nitrate (NH4NO3) & 0.0051 \\
\hline Mercury Nitrate $(\mathrm{Hg}(\mathrm{NO} 3) 2 . \mathrm{H} 2 \mathrm{O}$ & 0.0064 \\
\hline Sodium Nitrate (NaNO3) & 0.0165 \\
\hline Sodium Glycolate (NaC2H3O3) & 0.033 \\
\hline Sodium Sulfate (Na2SO4) & 0.0503 \\
\hline Sodium Chloride $(\mathrm{NaCl})$ & 0.0272 \\
\hline
\end{tabular}

Solutions made without the glycolate anion used the same compositions except sodium glycolate was not added.

Table A3-13 Dilute Waste at $\mathrm{pH} 12$

\begin{tabular}{|c|c|}
\hline Recipe & 1L Solution Mass, \\
\hline Sodium Carbonate $(\mathrm{Na2}$-O3) & 0.15 \\
\hline Calcium Nitrate $(\mathrm{Ca}(\mathrm{NO} 3) 2.4 \mathrm{H} 2 \mathrm{O})$ & 0.0061 \\
\hline Iron Nitrate $(\mathrm{Fe}(\mathrm{NO} 3) 3.9 \mathrm{H} 2 \mathrm{O})$ & 0.0024 \\
\hline Potassium Nitrate $(\mathrm{KNO} 3)$ & 0.0015 \\
\hline Magnesium Nitrate $(\mathrm{Mg}(\mathrm{NO} 3) 2.6 \mathrm{H} 2 \mathrm{O})$ & 0.001 \\
\hline Ammonium Nitrate $(\mathrm{NH} 4 \mathrm{NO} 3)$ & 0.0051 \\
\hline Mercury Nitrate $(\mathrm{Hg}(\mathrm{NO} 3) 2 . \mathrm{H} 2 \mathrm{O}$ & 0.0064 \\
\hline Sodium Nitrate $(\mathrm{NaNO} 3)$ & 0.0165 \\
\hline Sodium Glycolate $(\mathrm{NaC} 2 \mathrm{H} 3 \mathrm{O} 3)$ & 0.033 \\
\hline Sodium Sulfate $(\mathrm{Na2SO} 4)$ & 0.0503 \\
\hline Sodium Chloride $(\mathrm{NaCl})$ & 0.0297 \\
\hline Sodium Hydroxide $(\mathrm{NaOH})$ & 0.4 \\
\hline
\end{tabular}

Solutions made without the glycolate anion used the same compositions except sodium glycolate was not added. 